\title{
ECONOMICS
}

\section{GLOBAL CONSUMPTION PATTERNS, QUALITY AND FOOD DEMAND}

by

Kenneth W Clements

Business School, the University of Western Australia

and

\section{Long Hai Vo}

Business School, the University of Western Australia 
October 2021

\title{
GLOBAL CONSUMPTION PATTERNS, QUALITY AND FOOD DEMAND*
}

\author{
by \\ Kenneth W Clements ${ }^{\mathrm{a}, \mathrm{b}}$ and Long Hai $\mathrm{Vo}^{\mathrm{a}, \mathrm{c}}$
}

\begin{abstract}
There are significant disparities in the wealth of nations and how incomes are spent. For example, consumers in the poorest countries spend more than half of income on food, while in the richest countries, this is one-tenth or less. We use the recently published data from the International Comparison Program for 176 countries to estimate cross-country demands. Considerable progress can be made in accounting for much of the disparities in consumption patterns with this simple utility-maximisation model in which variations in incomes and prices are the key drivers. This leads to measures of the "quality" of consumption and its price based on a luxury-necessity-revealed-preference approach, as well as projections of future world food demand.
\end{abstract}

Keywords: Global consumption; Quality indexes; Engel's law; Food demand projections JEL classifications: D12; F61; Q11

\footnotetext{
*We would like to acknowledge helpful discussions with and advice from Simon Chang, Yihui Lan and Haiyan Liu, as well as the useful comments from participants in the Work-in-Progress Seminar at the Economics Department, Business School, the University of Western Australia.

${ }^{a}$ Economics Department, Business School, the University of Western Australia.

b Corresponding author. Contact: 35 Stirling Highway, Crawley, Perth, Western Australia 6009. Email: ken.clements@uwa.edu.au.

${ }^{c}$ Faculty of Finance, Banking and Business Administration, Quy Nhon University. Email: long.vo@uwa.edu.au.
} 


\section{TABLE OF CONTENTS}

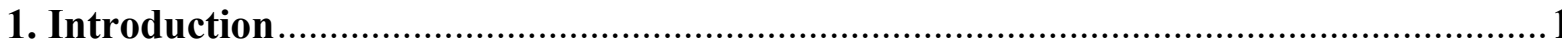

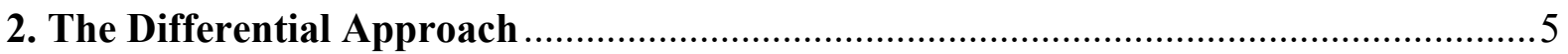

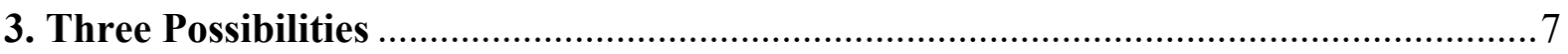

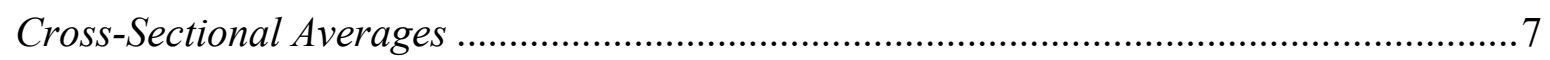

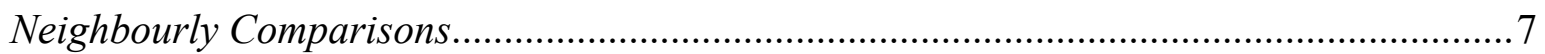

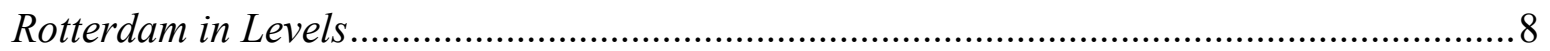

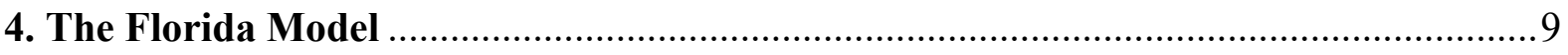

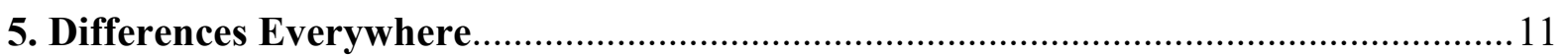

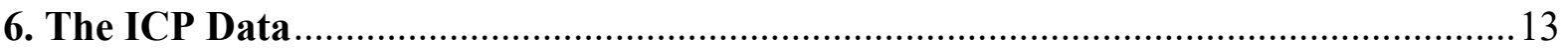

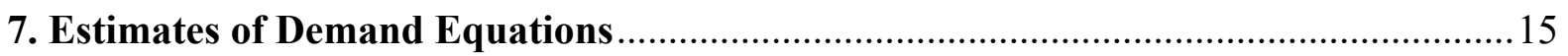

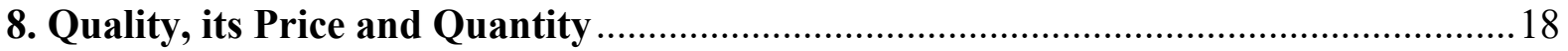

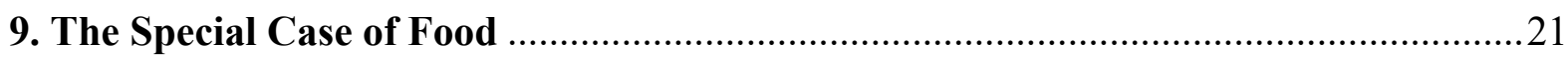

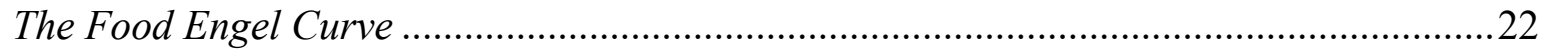

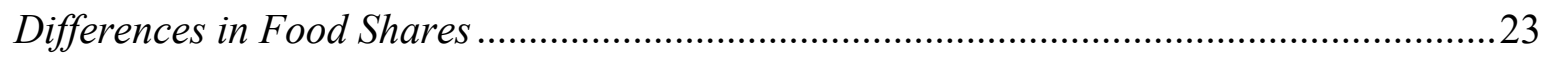

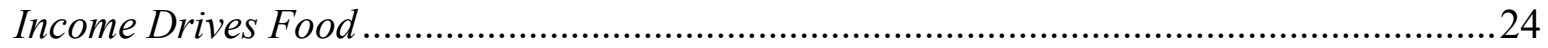

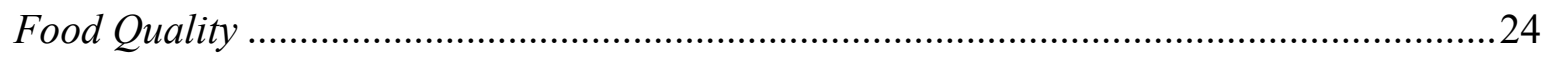

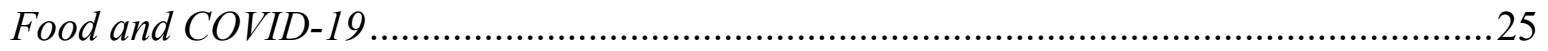

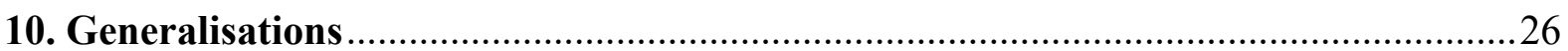

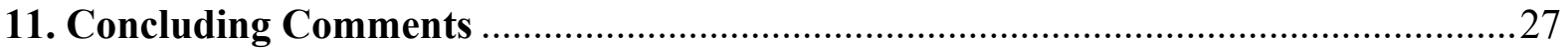

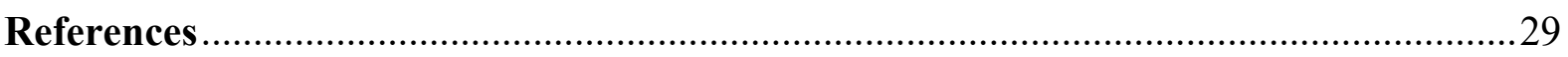

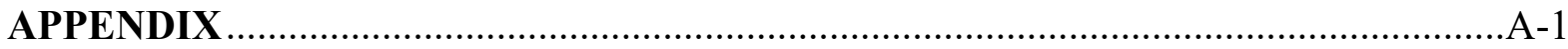

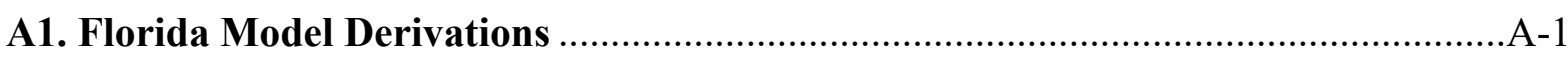

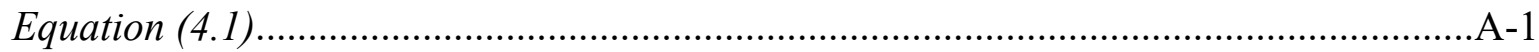

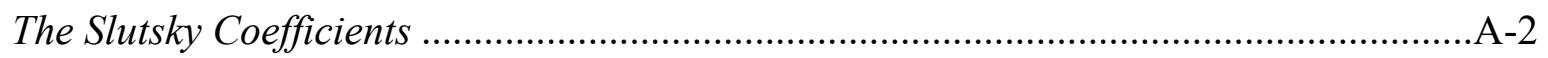

A2. Pairwise Differences Provide No Additional Information ....................................

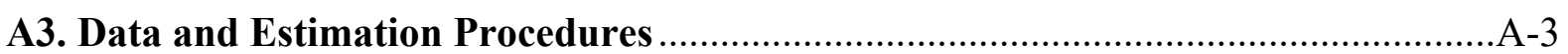

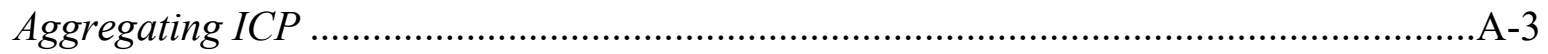

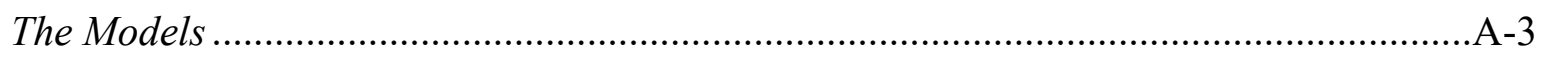

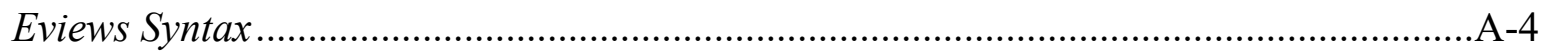

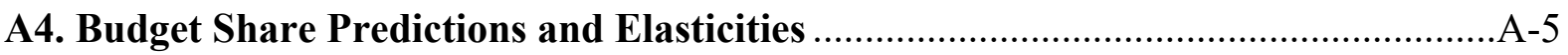

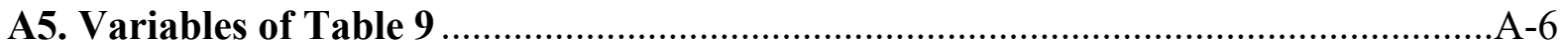

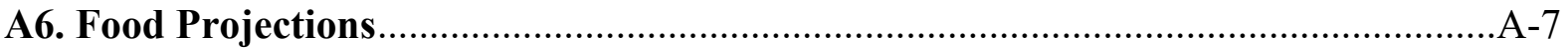

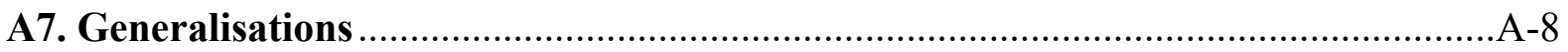

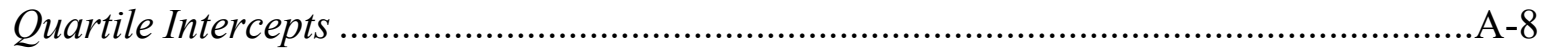

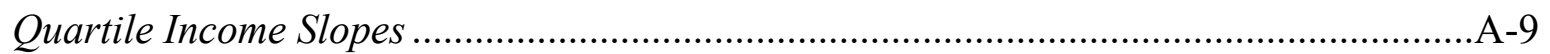

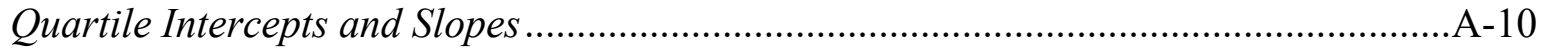

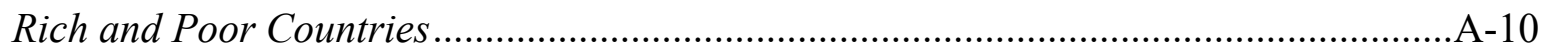

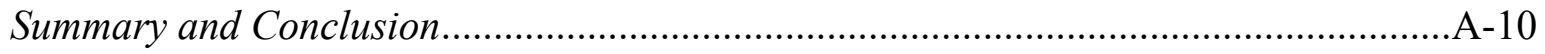

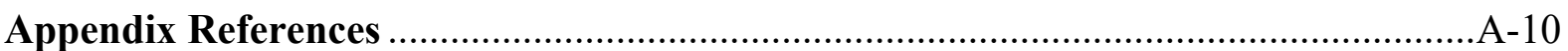




\section{Introduction}

There has been a spate of recent interest in the long-term evolution of expenditure patterns and their role in major changes in the structure of the economy. The fall in the share of income devoted to food consumption (the Engel effect) and the rise in the services share with increasing affluence is a demand-side example of the drivers of economic structure over the longer term. Such patterns are evident internationally where households in the poorest countries devote more than one-half of their incomes to food, while in the richest, the food share falls to 10 percent or less. Leading examples of this research include Boppart (2014), Comin et al. (2021), Herrendorf el al. (2013), Kongsamut et al. (2001), Matsuyama (2019) and Święcki (2017). This and related research models demand behaviour with equations derived from an algebraic form of the utility (direct or indirect) such as the non-homothetic CES (Comin et al., 2021), variants of the linear expenditure system (LES) (Stone, 1954) and the translog model (Christensen et al., 1975), or from the cost function in the case of the almost idea model (AI) (Deaton and Muelbauer, 1980). The same practice also dominates the related area of CGE modelling.

In view of the prominence of this practice, the first objective of this paper is to draw attention to a different way of modelling demands that can have attractions over popular alternatives: The differential approach that underlies the Rotterdam system (Barten, 1964; Theil, 1965, 1980). It is not widely understood that with modifications, this approach can be applied to a cross section of countries having no natural ordering, and thereby shed light on the determinants of consumption patterns over the longer term. ${ }^{1}$ The differential approach has several advantageous features, viz., the generality of its foundations in utility theory, its aggregation properties, its facility for hypothesis testing and its elegant simplicity. An appreciation of these features may stimulate its use in studies of structural change, CGE modelling and other applications.

The Rotterdam model is a member of the differential approach to demand analysis (Theil, 1980; Theil and Clements, 1987; Wohlgenant, 2021). This approach essentially involves four steps: (i) Starting with conventional Marshallian demand equations, take total differentials; (ii) convert to real-income-constant demands using the Slutsky equation; (iii) parameterise on certain slope coefficients; and (iv) impose the microeconomic constraints of

\footnotetext{
${ }^{1}$ For related research on cross-country demand analysis, see Goldberger and Gamaletsos (1970), Houthakker (1957, 1965), Kravis et al. (1982, Chpt. 9), Lluch and Powell (1975), Lluch et al. (1977), Parks and Barten (1973), Pollak and Wales (1987), Reimer and Hertel (2004) and Rimmer and Powell (1992).
} 
homogeneity and symmetry. This gives a system of demand equations linear in its transformed variables with linear constraints on the coefficients.

One advantage is that as this system is not derived from a specific form of the utility/cost function, it is consistent with any such function with the usual economic properties. In this sense, it is more general than the CES, LES and the AI models. Indeed, these models can be expressed as special cases of differential approach (Clements and Gao, 2015). As the utility function is a construct, it is not easy to have prior ideas regarding its precise algebraic form; using a generic utility function of the differential approach obviates this difficulty. Importantly, there are no restrictive assumptions of separability built into differential demands. For the Rotterdam version of the differential approach, a second advantage is its functional form: It is linear, which makes estimation and testing straightforward - tests of homogeneity, symmetry and separability hypotheses involve direct parametric restrictions. A third advantage is that the model has desirable aggregation properties making it consistent with the theory of the utility-maximising consumer (Barnett, 1979; Selvanathan, 1991; Theil, 1971). ${ }^{2}$

These advantages do not mean the approach is beyond reproach, however. Perhaps due to its European heritage and unorthodox derivation, there are lingering concerns regarding the status of the Rotterdam model and the differential approach (Clements and Gao, 2015). For example, the Rotterdam model has been rightly criticised for its linear Engel curves. Take the case of food consumption: An increase in income of a poor person is likely to result in an increase in food expenditure. Compare this with the impact on food expenditure of the same increase in income of a rich person. A linear Engel curve means the two effects coincide, which is clearly counterintuitive and conflicts with cross-sectional evidence. A second prominent criticism relates to the global properties of the model's functional form. In principle, income can vary from zero to billions (which is near-enough to infinity) and as income approaches this upper limit, it is argued the model implies constant budget shares, or Cobb-Douglas preferences. If true, this would be a telling defect as it means the model violates Engel's law, one of the most enduring of all laws of economics. This is known as the "McFadden (1964) critique".

One response to this critique is to recognise that all models are approximations to reality that only can aspire to provide an adequate account of behaviour over a limited range only. Typically, this is confined to the range spanned by the sample and extrapolations not "too far"

\footnotetext{
${ }^{2}$ Additionally, the Rotterdam model has a sufficient number of parameters to qualify as a flexible function form, one that is able to provide a second-order approximation to the "true" demand equations (Barnett, 1984; Mountain, 1988). This property is shared by a number of other models including the AI and the translog.
} 
outside that range. Thus, the implications of a model to situations far beyond anything observable is of limited practical significance, bordering metaphysical. A related response to McFadden involves the aggregation properties of the model when the number of consumers increases indefinitely. Asymptotically, the Rotterdam model converges to a well-define system that satisfies the requirements of utility maximisation (at least as an approximation), one that is not Cobb-Douglas. This is the so-called convergence approach to aggregation (Barnett, 1979; Selvanathan, 1991; Theil, 1971). For a detailed review of the Rotterdam approach including an assessment of its strengths and weaknesses, see Clements and Gao (2015).

There are two further objectives of this paper. One is to provide up-to-date estimates of the income and price-sensitivity of consumption patterns of a large number of countries with the recently released data by the International Comparison Program (World Bank, 2020). This information is useful input into country-specific as well as global CGE models designed for policy evaluation and simulation. Regarding this objective, our analysis provides several interesting findings. First, there is a strong support for Engel's law that food is a necessity. Second, tests reveal some support for the hypothesis of symmetry of the substitution effects, but additivity of the utility function appears to be too strong a restriction. Third, the "quality" of the consumption basket, based on the luxury-necessity distinction, increases with affluence and self-reported happiness in a country, as might be expected. But the rate of increase is slow, meaning that enhanced quality can only come with a substantial increase in income and happiness. The dual price of quality also increases with greater affluence, implying the cost of luxuries relative to necessities is higher in richer countries. As the rich consume luxuries intensively, the higher prices of these goods erode real incomes of the rich, that is, there is a progressive effect on the distribution of income. This impact is modest, however.

The final objective of the paper is to analyse in some detail the demand for food in the context of the whole budget. Food is of special interest as it is essential to life, consumed multiple times daily by most and is the dominant commodity in many budgets, especially those of the poor. We investigate the nature of the Engel curve for food and as mentioned before, present new evidence on Engel's law; and establish that income is the main driver of food consumption. We also illustrate the potential of the model in forecasting with projections of future food consumption, including the impact of the recent COVID-19 pandemic.

In the above approach, our cross-country demand analysis applies the same demand equations to all countries, meaning that tastes are taken to the same. This seemingly bold assumption attempts to account for the dispersion of consumption patterns across countries in terms of differences in incomes and relative prices, confining differences in geography, 
climate, culture, etc. to random disturbance terms. Such a treatment is likely to be more successful when applied to broadly defined commodity groups where there is likely to be less scope for country-specific factors to influence consumption independently of income and prices. Reflecting this idea, Theil and Suhm (1981, pp. 1-2) stated:

The underlying assumption is that "all countries are the same" in the sense that their per capita consumption of goods and services can be viewed as being generated by essentially the same consumer preferences. If this assumption is acceptable, the only (but major!) differences between countries result from their differences in income and prices, apart possibly from random effects. But this assumption immediately raises the objection that different nations have different cultures. We should expect that Indians spend little on meat and, indeed, the data produced by Kravis et al. (1982) confirm that this is so. The appropriate answer is that a cross-country demand system should be constructed, not for a very large number of detailed consumption categories, but only for a modest number of much broader categories. Accordingly, meat is part of a "good" called Food ...

The notion of constant tastes disciplines fuzzy thinking. Attempting to explain observed facts in terms of changes in tastes is not scientific as it can explain anything and everything, ruling out nothing, no matter how inconsistent with rational economic behaviour. Treating tastes as constant is advocated by Friedman (1962) and, forcefully, by Stigler and Becker (1977). As indicated by the above quotation, Theil and Suhm (1981) argue for constant tastes by restricting attention to broad aggregates, implying there is less scope for idiosyncratic behaviour the higher the level of aggregation of goods. The available evidence on this hypothesis of constant tastes is mixed. Selvanathan (1993) provides evidence consistent with the similarity of tastes internationally for broad aggregates of consumption. Clements et al. (2006) and Selvanathan and Selvanathan (2007), among others, also support constant tastes. Other studies with different datasets reach the opposite conclusion; for example, Selvanathan et al. (2021) find significant differences in tastes among six Australian states. Michail (2020) recently introduced the idea of tastes converging over the long run, a weaker requirement than constant tastes. Using an error-correction model for budget shares, he finds support for the long-run similarity of tastes among 27 European countries, with convergence taking place relatively quickly.

The remaining of the paper is organised as follows. The next section sets out the fundaments of the differential approach to demand analysis. The following two sections review several ways in which the approach can be applied in a cross-country context. Then, in Section 5 we introduce our demand model and discuss its advantages relative to the others. The newly 
released data from the 2017 round of the International Comparisons Program (World Bank, 2020), which refer to detailed spending patterns and the prices in 176 countries, are used in Section 6 to derive informal summary measures of the income and price-sensitivity of the consumption basket comprising nine categories of goods and services. Next, in Section 7, we estimate demand equations and present related results. Measures of the quality of the consumption basket, based on a luxury-necessity distinction, and its dual price are discussed in Section 8. In view of the prominence of food consumption, in Section 9 we examine in detail the food Engel curve, the role of food in the quality index and the implications of our estimates for future global food demand. Generalisations of the baseline model are considered in Section 10 as robustness checks, and concluding comments are provided in Section 11.

\section{The Differential Approach}

Let $q_{i}$ be the quantity demand of good $i$ and $p_{i}$ its price. If there are $n$ goods, then

$$
M=\sum_{i=1}^{n} p_{i} q_{i}
$$

is total expenditure, called "income" for short, and $w_{i}=\frac{p_{i} q_{i}}{M}$ is the $i^{\text {th }}$ budget share. The $i^{t h}$ differential demand equation is

$$
w_{i} d \log q_{i}=\theta_{i} d \log Q+\sum_{j=1}^{n} \pi_{i j} d \log p_{j} .
$$

Here, $\theta_{i}$ is the marginal share of $i$ and $\pi_{i j}$ is the $(i, j)^{\text {th }}$ Slutsky coefficient satisfying homogeneity, $\sum_{j=1}^{n} \pi_{i j}=0, i=1, \cdots, n$, and symmetry, $\pi_{i j}=\pi_{j i} ; i, j=1, \cdots, n$. The first variable on the right-hand side is

$$
d \log Q=\sum_{j=1}^{n} w_{i} d \log q_{i}
$$

This is a budget-share weighted average of the quantity changes, which is a Divisia index, interpreted as the change in real income. Dividing both sides of Equation (2.2) by $w_{i}$ shows that $\frac{\theta_{i}}{w_{i}}$ is the income elasticity of good $i$ and that $\frac{\pi_{i j}}{w_{i}}$ is the Slutsky (or compensated) elasticity of demand for $i$ with respect to the price of $j$.

Equation (2.1), the definition of (nominal) income, can be also taken to act as a budget constraint. To understand further the nature of $d \log Q$, take the differential of this constraint to give $\quad d M=\sum_{i=1}^{n}\left(q_{i} d p_{i}+p_{i} d q_{i}\right), \quad$ or $\quad$ using $\quad \frac{d x}{x}=d \log x, \quad d \log M=$ $\sum_{i=1}^{n} w_{i} d \log p_{i}+\sum_{i=1}^{n} w_{i} d \log q_{i}$. Write this as

$$
d \log M=d \log P+d \log Q,
$$

with $d \log P=\sum_{i=1}^{n} w_{i} d \log p_{i}$, a budget-share weighted average of the price changes, which is the Divisia price index, and $d \log Q$ the corresponding quantity index defined above. This 
clean split of the entire budget into price and quantity changes shows that the change in real income can be expressed as $d \log M-d \log P=d \log Q$. Thus, the real income variable in Equation (2.2), $d \log Q$, has the dual interpretation of (i) the change in money income deflated by the Divisia price index and (ii) a budget-share weighted average of the quantity changes, as in Equation (2.3). All this amounts to saying that the differential approach satisfies the factor reversal criterion. ${ }^{3}$

Application of the system to time-series data with the Rotterdam parameterization involves the use of successive changes in quantities, income and prices, and taking the marginal shares and Slutsky coefficients as constants. Thus, defining $D$ as the log-change operator from period $t-1$ to $t\left(D x_{t}=\log x_{t}-\log x_{t-1}\right)$, and $\bar{w}_{i t}=\frac{1}{2}\left(w_{i t}+w_{i, t-1}\right)$, we have

$$
\bar{w}_{i t} D q_{i t}=\theta_{i} D Q_{t}+\sum_{j=1}^{n} \pi_{i j} D p_{j t}+\varepsilon_{i t}
$$

where $D Q_{t}=\sum_{i=1}^{n} \bar{w}_{i t} D q_{i t}$ and $\varepsilon_{i t}$ is a zero-mean disturbance term to account for all other factors.

To assess factor-reversal in the context of the finite-change formulation (2.5), consider the log-change in the budget share, $D w_{i t}=D p_{i t}+D q_{i t}-D M_{t}$. Multiplying by $\bar{w}_{i t}$ and summing over $i=1, \cdots, n$ gives

$$
D M_{t}=D P_{t}+D Q_{t}-\sum_{i=1}^{n} \bar{w}_{i t} D w_{i t}
$$

where $D P_{t}=\sum_{i=1}^{n} \bar{w}_{i t} D p_{i t}$ is the Divisia index, as before. As the last term on the right of the above, $\sum_{i=1}^{n} \bar{w}_{i t} D w_{i t}$, measures the diversity of the change the composition of the budget and is (the negative of) the entropy of the distribution of changes in the shares (Shannon, 1948). As the term is generally non-zero, Equation (2.6) reveals that the factor-reversal criterion is not satisfied, so that $D Q_{t}=D M_{t}-D P_{t}+\sum_{i=1}^{n} \bar{w}_{i t} D w_{i t}$, which is no longer money income deflated by the budget-share weighted price index. However, as budget shares usually change only slowly over time, the troublemaker $\sum_{i=1}^{n} \bar{w}_{i t} D w_{i t}$ is likely to be small; in fact, very small: Of the third order in the log-changes in prices, quantities and income (Theil, 1975/76, p. 41, 175). For infinitesimal changes, the term vanishes: $\sum_{i=1}^{n} w_{i} d \log w_{i}=\sum_{i=1}^{n} w_{i} \frac{d w_{i}}{w_{i}}=$ $\sum_{i=1}^{n} d w_{i}=0$, taking us back to Equation (2.4).

\footnotetext{
${ }^{3}$ In non-logarithmic form, factor reversal states that the product of the quantity and price indexes should equal the income ratio; in logarithmic-change form, this is Equation (2.4). Fisher (1922) gives much prominence to factor-reversal.
} 


\section{Three Possibilities}

This section discusses the pros and cons of four ways of applying differential demands to a cross section of countries.

\section{Cross-Sectional Averages}

Equation (2.5) can be applied to a cross section of countries $c=1, \cdots, C$ by replacing each variable with its long-term average (over time) and time subscripts with country ones. This yields

$$
\bar{w}_{i c} D q_{i c}=\theta_{i} D Q_{c}+\sum_{j=1}^{n} \pi_{i j} D p_{j c}+\varepsilon_{i c} .
$$

Usually cross-country comparisons have to grapple with the tricky problem of what exchange rate to use to convert to a common currency -- the market rate, the Purchasing Power Parity (PPP) rate, or the Economist's implied Big Mac Index rate, etc. The attraction of the use of long-term averages in (3.1) is that all variables are unit-free, making them comparable across countries and currency conversions are not required.

The above approach was introduced by Selvanathan (1993, Chapter 1) and Chen (1999, Chap. 7). They estimated model (3.1) with time-averaged data for $C=13$ countries in the case of Selvanathan and 42 for Chen. The only difference - inconsequential in the current context - is that by employing Working's (1943) model for the income responses, Chen allowed the marginal shares to vary, rather than treating them as constants. While there might be a question regarding the applicability of the experience of the past to the present, taken as a whole, the estimates seem to be entirely satisfactory and the approach is promising. The disadvantage is the need for each country to have a substantial span of time-series data over which the average is to be taken.

\section{Neighbourly Comparisons}

Equation (2.5) considers changes from the previous year to the subsequent one. With a cross section of $C$ countries referring to a given point in time, we could consider the differences between countries $c$ and $d$, for $c, d=1, \cdots, C ; c \neq d$, and modify (2.5) to

$$
\bar{w}_{i c d} D q_{i c d}=\theta_{i} D Q_{c d}+\sum_{j=1}^{n} \pi_{i j} D p_{j c d}+\varepsilon_{i c d} .
$$

The variables here are completely analogous to those of $(2.5)$, that is, $\bar{w}_{i c d}=\frac{1}{2}\left(w_{i c}+w_{i d}\right)$, with $w_{i c}=\frac{p_{i c} q_{i c}}{M_{c}}$ is the budget share of $i$ in $c, D q_{i c d}=\log q_{i c}-\log q_{i d}, D Q_{c d}=$ $\sum_{i=1}^{n} \bar{w}_{i c d} D q_{i c d}$ and $D p_{i c d}=\log p_{i c}-\log p_{i d}$.

A popular way to make economic comparisons between countries is in terms of their income per capita. Then, if countries are ranked on this basis, comparing countries with their 
immediate neighbours on the income scale involves the country pairs $c, c+1$, while the pairs $c, c+k, k>0$, refer to countries $k$ steps apart. For model (3.2) this means setting $d=c+k$. Clements and Si (2018) estimated model (3.2) for $n=9$ commodities and $C=176$ countries using the 2011 round of the International Comparisons Program (ICP) (World Bank, 2013). Figure 1 plots the estimates against the income gap, $k=1,2, \cdots$. As can be seen, there seems to be considerable variability of the estimates. However, the majority of the marginal shares are reasonably stable in the middle range of the income gap corresponding to a ranking difference between the $40^{\text {th }}$ and $100^{\text {th }}$ places. Note also the increase in the standard-error band with income gap, which is associated with the decline in the corresponding number of observations.

The issue with this approach is that is it unclear what value of $k$ should be selected. Confining attention to neighbouring countries has the advantage they are probably more similar, with their smaller differences being a better approximation to the underlying infinitesimal changes. On the other hand, neighbourly comparisons could be regarded as parochial and not broad enough in ambition for a deep understanding of global consumption patterns. More fundamentally, the estimates are not invariant to the selected between-country income gap.

\section{Rotterdam in Levels}

We introduced in Section 2 the system of differential demand equations, the $i^{\text {th }}$ of which is Equation (2.2), $w_{i} d \log q_{i}=\theta_{i} d \log Q+\sum_{j=1}^{n} \pi_{i j} d \log p_{j}$. Barten (1989) suggested dropping the " $d$ 's" in this equation to give a "levels version" of the Rotterdam model,

$$
w_{i} \log q_{i}=\theta_{i} \log Q+\sum_{j=1}^{n} \pi_{i j} \log p_{j}, i=1, \cdots, n \text { goods. }
$$

This could then be applied to a cross-section of $C$ countries in the form $w_{i c} \log q_{i c}=$ $\theta_{i} \log \mathrm{Q}_{c}+\sum_{j=1}^{n} \pi_{i j} \log p_{j c}, i=1, \cdots, n, c=1, \cdots, C$.

The real income variable on the right-hand side of Equation (3.3) is defined as $\log Q=$ $\sum_{i=1}^{n} w_{i} \log q_{i}$. Using a parallel argument to that leading to Equation (2.6), it can be shown that

$$
\log M=\log P+\log Q-\sum_{i=1}^{n} w_{i} \log w_{i},
$$

where $M=\sum_{i=1}^{n} p_{i} q_{i}$ is income (as before) and $\log P=\sum_{i=1}^{n} w_{i} \log p_{i}$ is a price index. In this context, factor reversal requires $\log M=\log P+\log Q$, so the term $\sum_{i=1}^{n} w_{i} \log w_{i}$ is the discrepancy with $\log \frac{1}{n} \leq \sum_{i=1}^{n} w_{i} \log w_{i} \leq 0$. Equation (3.4) is, of course, a "levels version" of Equation (2.6). But there is an important difference, viz. the size of the deviation from factor reversal. In the case of (2.6), this discrepancy is $\sum_{i=1}^{n} \bar{w}_{i t} D w_{i t}$, a weighted average of changes in budget shares. As these changes are usually substantially smaller than the corresponding 
levels, it is likely that the deviation term of Equation (2.6) is substantially smaller than that of (3.4).

\section{The Florida Model}

Theil and co-authors developed another approach to cross-country demand analysis that culminated in the Florida model; the key references are Theil et al. (1989), Theil (1996) and Seale and Regmi (2006). ${ }^{4}$ According to this model, the demand for good $i$ takes the form (see Appendix A1 for derivations)

$$
w_{i c}=\alpha_{i}+\beta_{i} \log Q_{c}+\widetilde{w}_{i c}\left(\log \frac{p_{i c}}{\bar{p}_{i}}-\sum_{j=1}^{n} \widetilde{w}_{j c} \log \frac{p_{j c}}{\bar{p}_{j}}\right)+\phi \theta_{i c}\left(\log \frac{p_{i c}}{\bar{p}_{i}}-\sum_{j=1}^{n} \theta_{j c} \log \frac{p_{j c}}{\bar{p}_{j}}\right)+\varepsilon_{i c} .
$$

Here, $Q_{c}$ is real income of $c$ (real total expenditure, as defined by the ICP); $\widetilde{w}_{i c}$ is the budget share of $i$ in $c$ evaluated at world prices, taken to be

$$
\widetilde{w}_{i c}=\alpha_{i}+\beta_{i} \log Q_{c},
$$

which is Working's (1943) model; $\bar{p}_{i}$ is the world price of $i$ (the geometric mean over all countries); $\phi<0$ is the income flexibility (the inverse of the income elasticity of the income elasticity of the marginal utility of income); and $\theta_{i c}$ is the marginal share implied by (4.2), viz.,

$$
\theta_{i}=\alpha_{i}+\beta_{i}\left(1+\log Q_{c}\right) .
$$

For estimation, the right-hand sides of Equations (4.2) and (4.3) are substituted into (4.1) for the budget and margin shares.

Equation (4.1) is not as formidable is it might look. The observed budget share of goods in is explained by four terms. First, there is the real income term, $\alpha_{i}+\beta_{i} \log Q_{c}$. The budget shares of goods whose $\beta_{i}>0$ increase with income (prices remaining unchanged), and are thus luxuries. This term also appears in the almost ideal model of Deaton and Muellbauer (1980). The next two terms deal with price effects with each price deflated by the world average $\bar{p}_{i}$. The term $\widetilde{w}_{i c}\left(\log \frac{p_{i c}}{\bar{p}_{i}}-\sum_{j=1}^{n} \widetilde{w}_{j c} \log \frac{p_{j c}}{\bar{p}_{j}}\right)$ is proportional to the deflated price of good $i$ in country $c$ relative to a weighted average of all such prices. This measures the "direct effect" of a price change on the share - the share increases with its price when income is constant and there is no substitution effect. The second price term is $\phi \theta_{i c}\left(\log \frac{p_{i c}}{\bar{p}_{i}}-\sum_{j=1}^{n} \theta_{j c} \log \frac{p_{j c}}{\bar{p}_{j}}\right)$, which also involves a relative price of good $i$. The price index is a weighted average of the $n$ prices,

\footnotetext{
${ }^{4}$ Other important papers are Meade et al. (2014), Muhammad et al. (2011), Regmi and Seale (2010), Seale et al. (1991), Seale et al. (2003), Seale and Regmi (2006, 2009) and Seale and Solano (2012). The influence of this research is noted by Regmi and Seale (2010), who stated “(...) The estimates by Seale et al. of income and ownprice elasticities have been widely used as input in economic models, such as USDA's Baseline model, the Global Trade Analysis Project (GTAP) model, the International Food Policy Research Institute's IMPACT model, and others $(\ldots)$ ".
} 
but now the weights are marginal shares, $\theta_{j c}$, not budget shares, $\widetilde{w}_{j c}$. This marginally weighted average pf prices is known as the Frisch price index. The whole term represents the substitution effect of the price of $i$ on the demand for this good; as $\phi<0$ and $\theta_{i c}>0$, when the relative price of the good rises the quantity demanded and the budget share both fall. Finally, the disturbance $\varepsilon_{i c}$ accounts for everything else and is taken to be zero-mean.

Several aspects of the Florida model should be noted. First, it is a mixture of levels and changes. The income term deals with the level of income in the country, while the two price terms are formulated in terms of changes, changes in country $c$ 's prices from the world counterparts. And the level of the budget share is on the left-hand side of Equation (4.1). There is nothing incorrect with this formulation, but it is unusual, requiring some special effort to appreciate fully.

Second, the substitution effect is special. In Equation (4.1) this effect contains only the own relative price, $\log \frac{p_{i c}}{\bar{p}_{i}}-\sum_{j=1}^{n} \theta_{j c} \log \frac{p_{j c}}{\bar{p}_{j}}$. The coefficient of this relative price is $\phi \theta_{i c}$, and so for all goods, these coefficients are proportional to the corresponding marginal shares with the income flexibility as the factor of proportionality. The role of other prices in the substitution effect is confined to the Frisch index, $\sum_{j=1}^{n} \theta_{j c} \log \frac{p_{j c}}{\bar{p}_{j}}$. These special properties reflect preference independence, or an additive utility function, that lies behind the Florida model. Preference independence implies the marginal utility of each good is unaffected by the consumption of the others; that is, there are no utility interactions among commodities. It is sometimes argued this assumption is more likely to be applicable to the broad aggregates such as food, clothing, housing, etc. on the basis these are unlikely to have many good substitutes and little or no utility interactions. Preference independence also rules out inferior goods and complements. In this sense, it is a strong assumption.

Demand homogeneity and symmetry of the substitution effects are basic properties of utility-maximisation theory. Demand homogeneity means there is no money illusion, while symmetry means, for example, the impact on beer consumption of a one-dollar rise in the price of the bottle of wine is exactly equal to the impact on wine of an identical rise in beer prices. These propositions are not testable with the Florida model as they are built as maintained hypotheses.

A final comment on the substitution term, $\phi \theta_{i c}\left(\log \frac{p_{i c}}{\bar{p}_{i}}-\sum_{j=1}^{n} \theta_{j c} \log \frac{p_{j c}}{\bar{p}_{j}}\right)$. The marginal shares, $\theta_{i c}$, are variable, depending on the country's income according to Equation (4.3). Contrary to the Florida model, assume for the moment that Engel curves are linear, so 
that the marginal shares are constants. That is, $\theta_{i c}=\theta_{i}^{*}, i=1, \cdots, n, \forall c=1, \cdots, C$. In this case, the world prices drop into a term independent of country $c$ :

$$
\phi \theta_{i}^{*}\left(\log \frac{p_{i c}}{\bar{p}_{i}}-\sum_{j=1}^{n} \theta_{j}^{*} \log \frac{p_{j c}}{\bar{p}_{j}}\right)=\phi \theta_{i}^{*}\left(\log p_{i c}-\sum_{j=1}^{n} \theta_{j}^{*} \log p_{j c}\right)+\lambda_{i},
$$

where $\lambda_{i}=-\phi \theta_{i}^{*}\left(\log \bar{p}_{i}-\sum_{j=1}^{n} \theta_{j}^{*} \log \bar{p}_{j}\right)$, with $\sum_{i=1}^{n} \lambda_{i}=0$. This $\lambda_{i}$ could become part of an intercept term in the demand equation without any other consequences to the model. The conclusion is that the only reason world prices play a role in the substitution term of the Florida model is because of the nonlinear Engel curves. This role is could possibly be relatively modest. While nonlinear Engel curves are not in dispute, the above result points to another special (and possibly unusual) feature of the Florida model.

\section{Differences Everywhere}

The price and quantity variables in Equation (2.2) are in terms of (infinitesimal) changes. Thus, it seems natural to formulate a cross-country version in differences everywhere also. What is each country to be compared with? In the previous section we considered the comparison of country $c$ with $d$, with $d$ specified as a neighbour a fixed distance away in the income ranking. This approach could be extended to consider all pairs of countries. This bilateral treatment would involve $\frac{1}{2} C(C-1)$ distinct pairs and for reasonable values of $C$, $\frac{1}{2} C(C-1) \gg C$. Compared to a multilateral approach with $C$ observations (one for each country), this bilateral approach seemingly gives rise to a vastly greater number of observations to estimate demand Equation (3.2). But this is more apparent than real, as the underlying variability of the data (what matters for econometric estimation) of the two approaches is the same (see Appendix A2 for a further discussion).

As an alternative, we interpret the movements in prices and quantities as each country's differences from the world. World values that treat all countries symmetrically represent a neutral choice for the base of the comparisons. World values are taken to be averages over all countries:

$$
\log q_{i}^{*}=\frac{1}{C} \sum_{d=1}^{C} \log q_{i d} ; \quad \log p_{i}^{*}=\frac{1}{C} \sum_{d=1}^{C} \log p_{i d} ; w_{i}^{*}=\frac{1}{C} \sum_{d=1}^{C} w_{i d} .
$$

Country c's differences are, thus,

$$
\Delta \log q_{i c}=\log q_{i c}-\log q_{i}^{*} ; \quad \Delta \log p_{i c}=\log p_{i c}-\log p_{i}^{*}
$$

and the corresponding income difference is

$$
\Delta \log Q_{c}=\sum_{i=1}^{n} \bar{w}_{i c} \Delta \log q_{i c} ; \text { with } \bar{w}_{i c}=\frac{1}{2}\left(w_{i c}+w_{i}^{*}\right) .
$$


The change in $c$ 's income is a weighted average of the differences in the $n$ elements in the basket, with differences defined relative to world counterparts. The weights are budget shares, defined as averages of those of $c$ and the world.

Thus, the demand for $i$ becomes

$$
\bar{w}_{i c} \Delta \log q_{i c}=\theta_{i} \Delta \log Q_{c}+\sum_{j=1}^{n} \pi_{i j} \Delta \log p_{j c}+\varepsilon_{i c} .
$$

This equation is completely consistent with the differential demand (2.2), it is simply a discrete version. Note in particular changes of variables are on both sides of the equation, so there is a uniformity property. Demand homogeneity means that $\sum_{j=1}^{n} \pi_{i j}=0$, which can be imposed on (5.1) by substituting $-\sum_{j=1}^{n-1} \pi_{i j}$ for $\pi_{i n}$. The price term then becomes

$$
\sum_{j=1}^{n} \pi_{i j} \Delta \log p_{j c}=\sum_{j=1}^{n-1} \pi_{i j}\left(\log p_{j c}-\log p_{n c}\right)+\alpha_{i}
$$

where $\alpha_{i}=-\sum_{j=1}^{n-1} \pi_{i j} \log \left(\log p_{j}^{*}-\log p_{n}^{*}\right)$ is a term independent of $c$, with $\sum_{i=1}^{n} \alpha_{i}=0$. This weighted sum of world prices acts as an intercept $\alpha_{i}$ in the $n$ demand equations:

$$
\bar{w}_{i c} \Delta \log q_{i c}=\alpha_{i}+\theta_{i} \Delta \log Q_{c}+\sum_{j=1}^{n-1} \pi_{i j} \log \left(\frac{p_{j c}}{p_{n c}}\right)+\varepsilon_{i c} ; i=1, \cdots, n,
$$

Three aspects of system (5.3) can be noted. First, as currency units drop out of the deflated prices, the problem of converting from one currency to another is avoided. Second, the income variable $\Delta \log Q_{c}=\sum_{j=1}^{n} \bar{w}_{j c}\left(\log q_{j c}-\log q_{j}^{*}\right)$ is the difference between $\sum_{j=1}^{n} \bar{w}_{j c} \log q_{j c}$ and $\sum_{j=1}^{n} \bar{w}_{j c} \log q_{j}^{*}$, but as this second component on $c$ involves $\bar{w}_{j c}$ it cannot also be treated as a constant. Third, with constraint $\sum_{j=1}^{n} \pi_{i j}=0$ imposed, system (5.3) is equivalent to

$$
\bar{w}_{i c} \Delta \log q_{i c}=\alpha_{i}+\theta_{i} \Delta \log Q_{c}+\sum_{j=1}^{n} \pi_{i j} \log p_{j c}+\varepsilon_{i c} ; i=1, \cdots, n \text {. }
$$

Rather than constant marginal shares, we could alternatively use Working's (1942) model, $w_{i}=\alpha_{i}^{\prime}+\beta_{i} \log M$, which implies $\theta_{i}=w_{i}+\beta_{i}{ }^{5}$ In this case, system (5.4) requires two minor modifications: (i) Deviate the variable on the left from $\bar{w}_{i c} \Delta \log Q_{c}$ and (ii) replace $\theta_{i}$ on the right with Working's $\beta_{i}$ :

$$
\bar{w}_{i c}\left(\Delta \log q_{i c}-\Delta \log Q_{c}\right)=\alpha_{i}+\beta_{i} \Delta \log Q_{c}+\sum_{j=1}^{n} \pi_{i j} \log p_{j c}+\varepsilon_{i c} ; i=1, \cdots, n .
$$

with $\sum_{j=1}^{n} \pi_{i j}=0$. The Slutsky coefficients of equations (5.4) and (5.5) are subject to the symmetry constraint:

$$
\pi_{i j}=\pi_{i j} ; i, j=1, \cdots, n \text {. }
$$

The advantages this approach can be summarised as follows:

1. All variables are in a unified change form in model (5.1). Such a formulation is consistent with that of the original Rotterdam model. The advantages of this well-

\footnotetext{
${ }^{5}$ Other functional forms could also be used here; see Gao (2012).
} 
known model (its linearity, flexibility and aggregation properties, as mentioned) are shared with its cross-country variant. As prices and quantities are difficult to understand for a single country in isolation, measuring them relative to averages over all countries, as in Equation (5.1) for $i=1, \cdots, n$, makes for easier interpretation.

2. Relative to the levels approach discussed in Section 3, the departure from the factorreversal criterion is very likely to be smaller with model (5.1).

3. Symmetry and preference independence are maintained hypothesis in the Florida model. By contrast, these are testable hypotheses within model (5.1).

4. Model (5.1) requires data referring to one period for a number of countries. In contrast to the use of a cross section of averages (discussed in Section 3), this does not necessitate time-series observations for each country.

There is one disadvantage of the approach. The index of the change in country c's income in Equation (5.1) is $\Delta \log Q_{c}=\sum_{j=1}^{n} \bar{w}_{j c}\left(\log q_{j c}-\log q_{j}^{*}\right)$, a budget-share weighted average of the deviations of the $n$ quantities consumed in that country from world averages. This definition is perfectly satisfactory, and ensures that the sum over $i=1, \cdots, n$ of the lefthand side of Equation (5.1) equals $\Delta \log Q_{c}$ on the right, reflecting the allocation nature of the problem studied. But this measure cannot be interpreted as the deviation of income in $c$ from the world average, which would be $\sum_{j=1}^{n} \bar{w}_{j c} \log q_{j c}-\sum_{j=1}^{n} w_{j}^{*} \log q_{j}^{*}$. This is because in the world component of $\Delta \log Q_{c}$, which is $\sum_{j=1}^{n} \bar{w}_{j c} \log q_{j}^{*}$, the weights are not world weights but country c's. The discrepancy between the two measures obviously depends of the difference

between the two shares, $w_{j}^{*}-\bar{w}_{j c}$, which is equal to $\frac{1}{2}\left(w_{i}^{*}-w_{i c}\right)$. In many instances, this difference is likely to be small, but this cannot be guaranteed for all countries and all commodities. This disadvantage affects the interpretation of the income variable, but not the validity of the model.

\section{The ICP Data}

The data we use are from the 2017 round of the International Comparisons Program (World Bank, 2020), which refer to 176 countries listed in Table 1. This table also contains income per capita (strictly speaking, real total consumption per capita) and the share of total expenditure devoted to food. There is substantial dispersion of income (columns 2 and 6) across countries, with, for example, countries in the richest quartile are on average $\frac{65.9}{3.9} \approx 17$ times richer than those in the poorest quartile. The share of food (columns 3 and 7) is around 10 percent for the richest and increases to more than 50 percent for the poorest, which agrees with 
Engel's law. The relative price of food (columns 4 and 8) tends to increase as income falls the average for the richest quartile is 21.1 , while for the poorest, this is 28.9 , an increase of about almost 40 percent. Total consumption is split into $n=9$ commodity groups listed in Table 2, which gives in panel A the means of the budget shares for each income quartile. ${ }^{6}$ Measures of the dispersion of relative prices and quantities are given in panel B of the table, and these reveal a tendency to fall as income rises - interestingly, both standard deviations fall by about 13 percentage points in moving from the poorest to richest quartile. While the pricequantity correlation (given in the last row of the table) has the expected (negative) sign for the top two quartiles, some low-income countries cause it to change sign for the other two quartiles.

Figure 2 plots the budget shares against income. For most commodities, the shares are scattered fairly closely around the regression line; for food in particular the fit seems surprisingly good for the majority of countries. Food has a significantly negative slope coefficient, pointing to a less-than-unity income elasticity (Engel's laws again). Housing, health, recreation and miscellaneous all have highly significant slope coefficients, which is preliminary evidence of luxuries. Figure 3 shows that in almost all countries quantities are substantially more dispersed than prices; this stickiness of prices has been found in previous studies (see e.g., Clements, 2019).

Before turning to the estimation of the demand equation (5.5), it is useful to obtain some informal measures of the income and price sensitivity of consumption. Consider a pricequantity scatter plot. For good $i$ and country $c$, to control for the influences of income we use the difference in consumption relative to income, $\Delta \log q_{i c}-\Delta \log Q_{c}$. This measure is plotted against the difference in the good's price relative to item 9's price, $\Delta \log p_{i c}-\Delta \log p_{9 c}$, which is equivalent to $\log \frac{p_{i c}}{p_{9 c}}$ plus a constant. The top row of Figure 4 gives the scatter for food with countries grouped into the 88 that are poor (those with per capita income below the median), the 88 rich (above median) and all 176 together. ${ }^{7}$ For each group, the points are scattered around a downward-sloping regression line. Although there is considerable dispersion around the regression line, the negative slope provides some indication of the operation of the law of demand. The slope coefficient for the poor countries is -0.33 , which can be interpreted as an informal estimate of the price elasticity of demand for food. For the other goods, the regression

\footnotetext{
${ }^{6}$ For the composition of each commodity groups, see Appendix A3.

${ }^{7}$ In the case of food, deflating the growth in consumption by income leads to a substantial over adjustment (Clements, 2019). Engel's law says that the income elasticity of food is less than unity, meaning that deflation should be by only a fraction of income growth. As this is a preliminary analysis, we take the food elasticity to be $1 / 2$ and use the adjusted-growth $\Delta \log q_{i c}-\frac{1}{2} \Delta \log Q_{c}$. For the non-food goods, simply deflating by income seems to be adequate.
} 
lines are also negatively sloped and in the majority of cases, the price elasticities are less than one in absolute value. The exceptions where demand is more price elastic are furnishings and recreation for the poor; health for both groups; and education for the rich. Interestingly, for a number of commodities, the elasticity does not appear too different between poor and rich countries. These preliminary measures of substitutability are not unreasonable.

According to the law of demand, demand curves slope downwards. Thus, consumption of expensive items are below average, and vice versa. A further informal test of this law can be carried out by cross classifying price-quantity combinations, as in Table 3 for the 176 countries. If prices and quantities are independent, each $2 \times 2$ contingency table would have identical elements, whereas if the law of demand prevails, the off-diagonal elements dominate. On the basis of $\chi^{2}$-tests, in the vast majority of cases independence is rejected. Independence is not rejected only for food consumption in poor countries, and for restaurants in poor and all countries. This finding would seem to provide further evidence in favour of the law of demand. Finally, Figure 5 contains the price-quantity data cloud for all commodity-country pairs and shows that in $29+34=63$ percent of more than 1,400 cases, the demand for cheaper (more expensive) commodities is greater (less) than average, again illustrating the law of demand.

\section{Estimates of Demand Equations}

The baseline model we estimated is (5.5) with homogeneity imposed. When symmetry is not imposed, the OLS estimates coincide with the SUR estimates and panel A of Table 4 contains the results. To impose the cross-equation symmetry restrictions (5.6), we use a SURE and panel B of this table contains the results. Reassuringly, when symmetry is imposed the income coefficients do not change significantly and nor do the own-price Slutsky coefficients. The only major exception is the $\pi_{i i}$ for housing, which could possibly reflect measurement problems associated with the heterogeneous nature of housing arrangements.

As discussed in Section 4, the Florida model imposes the hypothesis of preference independence. This restriction means that the Slutsky coefficients take the form $\pi_{i j}=$ $\phi \theta_{i}\left(\delta_{i j}-\theta_{j}\right)$, where $\phi$ is the income flexibility (the reciprocal of the income elasticity of the marginal utility of income), $\theta_{i}$ is the marginal share of $i$ and $\delta_{i j}$ is the Kronecker delta. This restriction can be tested with the current approach and panel $\mathrm{C}$ of Table 4 contains the estimates. Relative to the symmetry-constrained estimates (panel B), the income coefficients do not change appreciably, while the corresponding standard errors fall by about 25 percent on average. The own-price Slutsky coefficients are fairly similar in the two panels, but preference 
independence substantially lowers the standard errors. Only a few of the off-diagonal Slutsky coefficients are significant under symmetry, but the lower standard errors under preference independence changes the picture rather dramatically. Finally, the income flexibility is estimated to be -0.84 , somewhat higher (in absolute value) than previous estimates that tend to be centred on -0.5 (Clements and Zhao, 2009). Panel D of the table gives the estimates when the price term is omitted. ${ }^{8}$

Table 5 contains tests of the restrictions. As can be seen from panel B, on the basis of likelihood ratio tests, symmetry is only just rejected, while preference independence and no price effects are firmly rejected. It is known that these asymptotic tests have a distinct tendency to over reject, so these results should not come as too much of a surprise and should probably be taken with a grain of salt. ${ }^{9}$ It would seem reasonable to conclude that symmetry is not too restrictive a property, but in view of the large $\chi^{2}$ values, preference independence and no price effects are likely to be inappropriate. Accordingly, in what follows, we shall use the estimates under symmetry.

The marginal share of good $i$ answers the question, if income rises by one-dollar, what fraction is spent on the good? Figure 6 contrasts the behaviour of the marginal shares with that of the budget shares (the fractions of total income spent on each good) as income varies. For ease of presentation, food etc. and clothing are combined and the composite (to be referred to as "food") is represented by the height of the yellow-shaded area. This reveals that the food marginal and budget shares both fall as income rises, with the marginal share falling faster. The major "offset" is for the shares of recreation etc. to rise. An implication of the faster fall in the food marginal share (relative to its budget share) is for its income elasticity to falls with higher income, which agrees with economic intuition.

A necessity (luxury) has a negative (positive) income coefficient $\beta_{i}$. Column 2 of panel $\mathrm{B}$ of Table 4 (the symmetry-constrained estimates) reveals that the food $\beta_{i}$ is significantly negative, and thus a necessity, in accordance with Engel's law. The only other necessity is clothing, but its $\beta_{i}$ is not significant. The remaining seven goods are luxuries, but two (furnishings and education) are not significantly so. Panel A of Table 6 gives the income elasticities. Averaging over all countries the income elasticity of food is 0.37 , which is the lowest of the nine commodities, while the highest is for recreation at 1.41 (column 6). These values seem reasonable. The other columns reveal some variation in the elasticities across the

\footnotetext{
${ }^{8}$ See the last section of Appendix A1 for details of the preference-independence specification. Appendix A3 gives details of the estimation procedures used in this section.

${ }^{9}$ On test performance, see Laitinen (1978), Meisner (1979) and Theil (1987).
} 
income distribution. The largest change is for food, where the elasticity falls from 0.73 for the poorest countries to -0.28 for the richest, which means food is inferior for the rich. While not many countries are in this category, taken at face value this finding could reflect growing health concerns among richer consumers regarding obesity and other medical conditions associated with over-eating. According to the World Health Organisation, 39 percent of adults were overweight in 2016 and 16 percent obese, and many are concerned with this issue. ${ }^{10}$ More will be said about food demand in Section 9.

The own-price elasticities are given in panel B of Table 6. These are all negative and the majority less than unity, which is understandable for broad aggregates that are unlikely to have many good substitutes. On average, recreation is the most elastic good, which again seems reasonable.

While the elasticities deal with the income and price sensitivity of consumption patterns, they do not determine the overall importance of these factors. This involves the elasticities, the variation of income and prices, and their covariances with consumption. To address this issue, it is convenient to focus on the budget shares, $w_{i c}=\frac{p_{i c} q_{i c}}{M_{c}}$, which are unit free. The set of predicted shares for all 9 goods, $\widehat{w}_{i c}, i=1, \cdots, 9$, can be systematically compared to actual shares by using the information inaccuracy, $\Sigma_{i=1}^{9} w_{i c} \log \left(\frac{w_{i c}}{\widehat{w}_{i c}}\right)$. When multiplied by 100 , this is a weighted mean of the percentage prediction errors, with budget shares as weights to reflect the relative importance of commodities. This measure is nonnegative, decreases as the quality of the predictions improves and is zero when the predictions are perfect.

We start with a naïve predictor, the cross-country means of the shares, which can be termed an unconditional prediction. The first element of the last column of panel A of Table 7 is 10.55 . This is $(\times 100)$ the inaccuracy averaged over all countries. By how much is this reduced when we add information about income and prices? Using income of each country as a predictor, the inaccuracy is 8.37 , a reduction of 21 percent (see the second element of the column). When income and prices are used simultaneously, the inaccuracy decreases by 33 percent (the third element), giving a marginal effect of prices a further reduction of $33-21=$ 11 percent. Comparing this with the 21-percent reduction on account of income alone, it can

\footnotetext{
10 World Health Organisation source: WHO Fact Sheet, https://www.who.int/news-room/factsheets/detail/obesity-and-overweight, 9 June 2021. Anecdotal evidence of concern overweight issues is given by a Google search (in September 2021) of the phrase "weight loss products" which returns 1.7 billion hits (in a bit over half a second).
} 
be concluded that income is the dominant driving force of the observed differences in consumption patterns across countries: Income differences are approximately twice as important as prices. ${ }^{11}$ Panel B of the table will be discussed in Section 9.

\section{Quality, its Price and Quantity}

A popular way of measuring the quality of a good is in terms of its physical attributes - for a car, its reliability, fuel efficiency, acceleration, emissions, etc., for a laptop, its memory capacity, processing speed, aesthetic design, etc. The hedonic-regression approach to quality is seemingly objective, but choices have to be made regarding what is included on the list of characteristics. Additionally, properties of some important goods cannot be measured in terms of a 0-1 dummy variable. For a car, think of the perceived "style", its "feel" or if it is simply "fashionable" with influencers. In other words, there is subjectivity regarding what is priced. Services, an important component of consumption, have no physicality, making them difficult to describe in precise, objective terms. How can the quality of surgery or an expensive restaurant dinner, for example, be measured? One way is with their income elasticities. When income rises, relatively more luxuries and less necessities are consumed. The choices of the consumer thereby identify luxuries as being more desirable, or of higher quality, necessities of lower quality. Importantly, this approach applies equally to services. This leads to a revealedpreference index of quality, as well as a companion price index, requiring no prior judgements of what the consumer ultimately desires (Clements and Gao, 2012; Theil 1975/76). ${ }^{12}$

As a budget-share-weighted average of the income elasticities is unity, this is a natural dividing line between those goods that are more preferred, or of higher quality, and those less preferred, or of lower quality. Suppose good $i$ is a luxury $\left(\eta_{i}>1\right)$ and its consumption increases $\left[d\left(\log q_{i}\right)>0\right]$. Then, since $\left(\eta_{i}-1\right) d\left(\log q_{i}\right)>0$, we could say this good contributes positively to the growth in quality. The growth in consumption of a necessity diminishes quality, as does a fall in that of a luxury $\left[\left(\eta_{i}-1\right) d\left(\log q_{i}\right)<0\right]$. For the quality of

\footnotetext{
${ }^{11}$ The other columns of this panel reveal differences in the quality of predictions across the income distribution. The model seems to perform best for the richest countries and not well for those in the third income quartile. However, as the parameters of the model take the same value for all countries, the SUR estimator minimises the weighted sum of squares over all commodities and all countries. Consequently, not too much weight should be accorded to the predictions for sub-groups of countries.

${ }^{12}$ In a recent paper, Caron et al. (2020) find a significant positive correlation between income elasticities and the skill-intensity of goods. Although this refers to predominantly intermediate inputs, this finding seems broadly consistent with the idea of income elasticities reflecting quality. Caron et al. (2020) also refer to the related literature on trade and quality (for example, Feenstra and Romalis, 2014; Hallak, 2010), as well as the link between quality and skilled labour (Fieler et al., 2018).
} 
the whole basket comprising $n$ goods, we simply take a budget-share-weighted average of all such terms, $\sum_{i=1}^{n} w_{i}\left(\eta_{i}-1\right) d\left(\log q_{i}\right)$, which is equivalent to

$$
y_{\eta q}=\sum_{i=1}^{n} w_{i}\left[\eta_{i}-1\right]\left[d\left(\log q_{i}\right)-d(\log Q)\right],
$$

where $d(\log Q)=\sum_{i=1}^{n} w_{i} d\left(\log q_{i}\right)$ is the Divisia volume index. This weighted covariance between income elasticities and quantity changes is an index of the quality of consumption. When $y_{\eta q}>0(<0)$, on average, the consumption of luxuries grows (falls) relative to that of necessities and the quality of consumption is said to improve (diminish). In other words, when income elasticities are positively (negatively) correlated with quantity changes, quality increases (decreases).

There are analogous indexes of the quality of expenditures and the price of quality, both expressed as weighted covariances:

$$
\left\{\begin{array}{c}
y_{\eta, p q}=\sum_{i=1}^{n} w_{i}\left[\eta_{i}-1\right]\left[d\left(\log p_{i} q_{i}\right)-\sum_{i=1}^{n} w_{i} d\left(\log p_{i} q_{i}\right)\right] \\
y_{\eta p}=\sum_{i=1}^{n} w_{i}\left[\eta_{i}-1\right]\left[d\left(\log p_{i}\right)-\sum_{i=1}^{n} w_{i} d\left(\log p_{i}\right)\right] .
\end{array}\right.
$$

When, on average, expenditures move towards luxuries, away from necessities, $y_{\eta, p q}>0$. The covariance $y_{\eta p}$ is positive when, on average, the prices of luxuries rise relative to those of necessities. Compared to the poor, the rich consume relatively more (less) luxuries (necessities), so $y_{\eta p}>0$ means the pattern of price changes erodes the real incomes of the rich, or has a progressive effect on the distribution of real income. The measures (8.1)-(8.2) satisfy a type of factor reversal property, viz., $y_{\eta, p q}=y_{\eta p}+y_{\eta q}$, or $y_{\eta, p q}-y_{\eta p}=y_{\eta q}$. As $y_{\eta p}$ acts as the deflator that transforms the quality of expenditures into the quality of consumption, this index can be identified as the price of quality.

Table 8 and Figure 7 present quality indexes for each country. These show that the quality of consumption rises with income, as might be expected. Less expected is the slow increase in quality. This can be seen clearly from the table below that summarises these results in the form of quartile averages. The poorest quartile has mean income per capita 86 percent below the world average and the quality of its consumption is only about 11 percent lower; in the top quartile, income is 130 percent above average, while quality is only 10 percent higher. Evidently, improvement of consumption quality only comes with a large increase in income. According to the last column of the table, the price of quality moves in the same direction as the quantity index; with higher incomes, the prices of luxuries rise relative to those of necessities. As discussed above, this change in the structure of prices is progressive in its impact on the income distribution. But it should be emphasized this effect is very modest - less than that of the quality of consumption. 


\begin{tabular}{ccccc}
\hline \hline & \multicolumn{2}{c}{ Income per capita } & \multicolumn{2}{c}{$\begin{array}{c}\text { Quality indexes } \\
(\times 100)\end{array}$} \\
\cline { 2 - 5 } Quartile & $\begin{array}{c}\text { Level } \\
(\text { U.S }=100)\end{array}$ & $\begin{array}{c}\text { Percentage } \\
\text { difference from } \\
\text { world average }\end{array}$ & Quantity & Price \\
\hline 1 & 65.9 & 130.4 & 9.7 & 2.6 \\
2 & 30.9 & 8.0 & 3.7 & 0.2 \\
3 & 13.7 & -52.1 & -2.2 & -0.6 \\
4 & 3.9 & -86.4 & -11.1 & -2.2 \\
\hline Mean & - & 0 & 0 & 0 \\
\hline
\end{tabular}

Table 9 investigates the determinants of quality. As can be seen from panel A, for all countries the major determinants are income and self-reported happiness. This applies to both the quality of consumption and its price. These effects are more pronounced in rich countries, while happiness has insignificant effect on prices for the poor (panels B and C). The income and happiness elasticities of consumption quality are always substantially larger than those of prices; and in all cases, the happiness elasticities are substantially larger than those of income. ${ }^{13}$ Income inequality has a significantly positive impact on the quality of consumption of the rich, but not the poor. For prices, the reverse occurs - inequality is significant for the poor, not the rich. Accordingly, greater inequality in poor countries leads to significantly higher prices of luxuries relative to necessities. Human capital plays a role in determining consumption quality for the rich, not the poor. Access to the internet and the degree of urbanization are mostly insignificant. The majority of elasticities in this table are small, which illustrates again the above-point regarding the modest effect of income on quality.

Panels A and B of Figure 7 are scatter plots of quality against income. These make clear the small income elasticities. Panel $\mathrm{C}$ is a price-quantity scatter for quality in which the effects of income and other variables are controlled for by using the residuals from a regression, details

\footnotetext{
${ }^{13}$ The OLS estimator of the slope coefficient of a regression of $y$ on $x$ is $\hat{\beta}_{x}=\frac{\rho_{y, x} \cdot \sigma_{y}}{\sigma_{x}}$, where $\rho_{y, x}$ is the correlation coefficient and $\sigma_{k}$ is the S.D of variable $k(k=y, x)$. Thus, with $y$ quality and $x$ as first income (denoted by $M$ ) and then happiness $(H), \frac{\widehat{\beta}_{H}}{\widehat{\beta}_{M}}=\frac{\rho_{y, H} \sigma_{M}}{\rho_{y, M} \cdot \sigma_{H}}$. For all countries, $\rho_{y, H}=0.77, \rho_{y, M}=0.87, \sigma_{M}=1.18$ and $\sigma_{H}=0.22$. As the two correlations are not too different, $\frac{\widehat{\beta}_{H}}{\widehat{\beta}_{M}} \approx \frac{\sigma_{M}}{\sigma_{H}}=\frac{1.18}{0.22}=5.4$, which is of the same order of magnitude as the differences between the elasticities in Table 9. Although the correlations are similar, the happiness coefficient is much larger than the income one because of the vastly higher variability of income as compared to that of happiness. Notwithstanding the simplification here that income and happiness have separate regressions (rather than considering the two variables simultaneously), this points to one possible source of the difference. Another possibility is that due to measurement error in income, happiness is a better proxy than income of the longer-term situation of the consumer, the driver of quality.
} 
of which are in the notes to this figure. For both the poor and rich countries, there is a weak negative relationship. For the rich, for example, the estimated slope coefficient indicates the price elasticity the demand for quality is about $-1 / 4$, so quality is highly price inelastic. This might almost be taken as saying "there is no substitute for quality", which is the registered trademark of the Australian biscuit manufacturer Arnott's (the producer of Tim Tams, an Australian favorite). ${ }^{14}$ However, this slope coefficient (as well as the one for the poor) is less than twice its standard error, so strong conclusions on this matter cannot be drawn.

The finding that in rich countries, the price of quality increases (modestly) with income implies a positive correlation between the relative prices of luxuries and income, and vice versa for necessities. In the main, this is corroborated by the correlation for the rich countries given in last row of panel $\mathrm{C}$ of Table 10 (the income elasticities that identify luxuries/necessities are reproduced in the top row of this table). The relative price of food (with an income elasticity of 0.4 , a necessity) falls with income, while those of restaurants, recreation and miscellaneous (all clear luxuries) rise. The exceptions to the rule are the prices of housing (income elasticity of 1.2), whose correlation with income is -0.2 , and health (income elasticity of 1.3 and correlation -0.1). For some countries, perhaps these prices are affected by special institutional factors such as public provision of medical services. The corresponding correlations for the poor (in the last row of panel B) are lower for the three clear luxuries, while the one for food is now a small positive value, probably indistinguishable from zero. These measures are broadly consistent with the previous discussion of the quality indexes. The other parts of this table provide the inter-price correlations - the larger correlations tend to be between clothing and housing and, for the rich, among the service-intensive group comprising education, restaurants and recreation.

\section{The Special Case of Food}

As mentioned previously, the effects of Engel's law can be clearly seen in the ICP data. Poor countries spent 50 percent or more of their income on food, while the rich spent 10 percent or less. Another distinguishing feature of food is that according to the income elasticity, apparently food is an inferior good in the richest countries. This section investigates these and other features of food consumption.

\footnotetext{
${ }^{14}$ https://trademarks.justia.com/735/99/there-is-no-substitute-for-73599968.html
} 


\section{The Food Engel Curve}

Working's model states that the food budget share $\left(w_{F}\right)$ is a linear function of the logarithm of income, $w_{F}=\alpha_{F}+\beta_{F} \log M, 0<w_{F}<1, \beta_{F}<0$. However, there is a potential problem here as the share can exceed unity for a sufficiently low income, and turn negative for high values, thus violating the 0-1 range. If this occurs, the model breaks down. Are these 0-1 violations a realistic possibility with the ICP data? Relatedly, is food really inferior for the rich? Prior research finds no major difficulties: Chen (1999) estimated Working's model with data for 42 countries and found no $0-1$ violations, and if the US (the then richest country) continued to grow at its historical rate, food would become inferior in about 2005.

Figure 8 analyses these issues with the ICP data. The budget share of each country is represented by a red circle, while the red downward-sloping line is Working's model with income coefficient $\hat{\beta}_{F}=-11.75$. As can be seen, the horizontal intercept corresponds to a per capita income of about $\$ 91,000$. The richest ICP country is Bermuda with a per capita income (that is, consumption) of about $\$ 48,000$; as this is substantially below $\$ 91,000$, it seems safe to conclude the food share does not violate the zero lower bound within a realistic relevant range. At the other end of the distribution, at very low-income levels, the model implies the food share approaches 67 percent, well below the upper bound of unity; so for all relevant low levels of income, the implied budget shares are far away from the boundary. Therefore, Working's model seems to be a satisfactory description of these data. The implied marginal shares are given by the blue line, which lies everywhere below the budget-share line by the value $\hat{\beta}_{F}$. The marginal shares are negative for the richest countries with incomes greater than about $\$ 33,000$, the horizontal intercept. For these countries, food is inferior, as is indicated by the negative income elasticities (the green curve and the green crosses). This is a surprise, but perhaps it reflects heightened health consciousness associated with weight and avoidance of over-eating that can come with increased wealth.

Engel's law relates to the fall in the food share with increasing income. The strong version of Engel's law offers the more precise numerical statement that the food share falls by 10 percentage points when income doubles. Theil et al. (1989) introduced this law on the basis of an estimate of the income coefficient of $\hat{\beta}_{F}=-0.15$. The change in income that generates a 10-percentage-point fall in the share is $\exp \frac{-0.10}{\widehat{\beta}_{F}}$; so when $\hat{\beta}_{F}=-0.15, \exp \frac{-0.10}{-0.15} \approx 2$, a doubling of income. With our estimate $\hat{\beta}_{F}=-0.1175$, exp $\frac{-0.10}{-0.1175} \approx 2.3$, which means income 
has to increase by a factor somewhat larger than $2 .{ }^{15}$ As income has to rise only by about 15 percent more, it can be concluded that our result is not substantially inconsistent with the strong version of Engel's law.

\section{Differences in Food Shares}

To analyse further the pattern of differences in food shares, we divide the 176 countries in income quartiles (44 in each) and denote these by $\boldsymbol{S}_{1}, \cdots, \boldsymbol{S}_{4}$, with $\boldsymbol{S}_{1}$ the richest and $\boldsymbol{S}_{4}$ the poorest. Within each quartile, we order countries by decreasing income and denote the food share in country $c$ by $w_{F c}$. From Engel's law, $w_{F c}<w_{F d}$ for $c<d, c, d \in S_{g}$, and the $44 \times 44$ matrix of differences $\boldsymbol{D}_{g g}=\left[w_{F c}-w_{F d}\right]$ is skew symmetric with negative elements in the upper triangle. Then, the four matrices $\boldsymbol{D}_{g g}, g=1, \cdots, 4$, can be considered as diagonal blocks of a $176 \times 176$ matrix for all countries. The off-diagonal blocks $\boldsymbol{D}_{g h}, g \neq h$, are skew symmetric, implying that the $176 \times 176$ matrix $\boldsymbol{D}=\left[\boldsymbol{D}_{g h}, g, h=1, \cdots, 4\right]$ is also skew symmetric. The pattern of $\boldsymbol{D}$ is summarized by medians in panel A of Table 11, where, for example, the first element of column $2,-36.01$, indicates that food shares of the richest countries are, on average, 36 percentage points less than those of the poorest.

Under Working's model, the difference in food shares between two countries $c$ and $d$ is $w_{F c}-w_{F d}=\beta_{F}\left(\log M_{c}-\log M_{c}\right)$, or $\beta_{F}=\frac{w_{F c}-w_{F d}}{\log M_{c}-\log M_{c}}$. Thus, the difference in the shares per unit difference in log income provides some indication of how the slope parameter $\beta_{F}$ might vary across countries. Panel $\mathrm{C}$ of Table 11 gives the ratios for country groups. On average, this ratio is slightly more than about -13 and while there is some dispersion across the income distribution, this is modest and not inconsistent with the prior estimate $(\times 100)$ of $\beta_{F}$ from the demand system of -12.02 , in view of its standard error of 0.83 (panel B of Table 4). ${ }^{16}$ With one exception, the ratios of panel $\mathrm{C}$ are contained within the three-standard-error band $-12.02 \pm 3 \times 0.83$. Although only informal evidence, the relative stability of the ratios gives some reassurance that the estimate of -12 can be regarded as a reasonably reliable estimate of this fundamentally important parameter.

\footnotetext{
${ }^{15}$ Interestingly, using the ICP 2011 data (the previous round of the ICP), Clements (2019) obtained $\hat{\beta}_{F}=$ -0.1195 , close to the current estimate. As mentioned above, Theil et al. (1989) obtained $\hat{\beta}_{F}=-0.15$. Why the difference? The income growth over the intervening three decades means falling shares in many countries and a movement down the Engel curve, if it were stable. However, it has been suggested the Engel curve shifts down over time, as income is understated (Costa, 2001, Hamilton, 2001 and Nakamura, 1996). An equi-proportional understatement in all countries gives rise to a downward parallel shift, with unchanged slope. Arguably, there is more scope for income to be understated in poor countries, leading to a more pronounced downward shift in their part of the Engel curve. This could account for our curve to be moderately flatter.

${ }^{16}$ This is also close to the Figure 6 estimate (where the role of prices is omitted) of $\beta_{F}=-11.75$.
} 


\section{Income Drives Food}

Panel B of Table 7 deals with the relative importance of income and price differences for food demand. From the last column, conditioning on income leads to the information inaccuracy being 69 percent below that associated with the naïve model of constant shares. As the marginal effect of prices alone is only about $73-69=4$ percent, again income dominates prices, but much more so for food than for all commodities simultaneously (panel A). ${ }^{17}$

\section{Food Quality}

In view of the prominence of food, it is of considerable interest to analyse its role in the measurement of quality. This is straightforward due to the additive nature of the quality index (8.1). Thus, if food is the first commodity,

$$
\begin{aligned}
y_{\eta q}= & w_{1}\left[\eta_{1}-1\right]\left[d\left(\log q_{1}\right)-d(\log Q)\right] \\
& +\left(1-w_{1}\right) \sum_{i=2}^{9} \frac{w_{i}}{1-w_{1}}\left[\eta_{i}-1\right]\left[d\left(\log q_{i}\right)-d(\log Q)\right],
\end{aligned}
$$

and so the contribution of food can be measured by the share $\frac{w_{1}\left[\eta_{1}-1\right]\left[d\left(\log q_{1}\right)-d(\log Q)\right]}{y_{\eta q}}{ }^{18}$ As the food income elasticity $\eta_{1}<1$, the contribution of food to overall quality will be positive when $d(\log Q)>d\left(\log q_{1}\right)$, that is, when real income grows faster than food. Food "contributes" positively to improved quality when the consumption basket moves away from the important necessity, food. This will be the case for many rich countries, while for the poor, food tends to grow faster than income and so diminishes overall quality. This is clearly illustrated in Table 12 with the contrasting behaviour of the UAE (a rich country) and Mozambique (poor). For the UAE, the quality of the overall consumption basket is 11.5 percent above the world average (column 3), and almost 88 percent of that is accounted for by food (column 8). The quality of consumption of Mozambique is 17.9 percent below world average with only 39 percent stemming from food. These results are not atypical, as shown by Table 13, which gives the food quality contributions by income quartile.

\footnotetext{
${ }^{17}$ As discussed above, the information inaccuracy for sub-groups of countries need to be interpreted with due care. Nevertheless, in qualitative terms, the other columns of panel B of Table 7 reveal a similar pattern across the income distribution for food and that for all 9 goods. That is, income and prices have the largest predictive power among the richest countries, and the least for the third-quartile countries.

${ }^{18}$ The second line of Equation (9.1) is proportional to the quality of the non-food part of consumption, the withingroup covariance between the conditional income elasticities and consumption, $\sum_{i \in G} w_{i}^{\prime}\left[\eta_{i}^{\prime}-1\right]\left[d\left(\log q_{i}\right)-\right.$ $\left.d\left(\log Q_{S}\right)\right]$. Here, $\boldsymbol{G}$ is the set of eight non-food items; $w_{i}^{\prime}=\frac{w_{i}}{w_{G}}, i \in \boldsymbol{G}$, the budget share of $i$ within the group $\boldsymbol{G}$, with $\mathrm{W}_{\boldsymbol{G}}=\sum_{i \in G} w_{i}$, the budget share of the group; $\eta_{i}^{\prime}=\frac{\eta_{i}}{N_{G}}, i \in \boldsymbol{G}$, the conditional income elasticity, with $N_{\boldsymbol{G}}=$ $\sum_{i \in G} w_{i}^{\prime} \eta_{i}$, the group income elasticity; and $d\left(\log Q_{G}\right)=\sum_{i \in \boldsymbol{G}} w_{i}^{\prime} d\left(\log q_{i}\right)$ the volume index of $\boldsymbol{G}$. The factor of proportionality is $\left(1-w_{1}\right) \mathrm{N}_{G}=\sum_{i \in G} w_{i} \eta_{i}$. With this interpretation, the overall quality index (9.1) is a weighted average of the quality of food and that of non-food, with budget shares as weights.
} 


\section{Food and COVID-19}

Recent research has identified key elements of the effects of the coronavirus pandemic on food demand/security and calorie intake (FAO, 2021; Laborde et al., 2021; O'Connell et al., 2021) as well as the broader implications of pandemic-induced food expenditure shocks on GDP (Beckman and Countryman, 2021). We show the potential of our approach to contribute to this research with some illustrative food demand projections. Write demand Equation (5.5) for food as $\bar{w}_{F, c}\left(\Delta \log q_{F, c}-\Delta \log Q_{c}\right)=\beta_{F} \Delta \log Q_{c}+\sum_{j=1}^{9} \pi_{F, j} \Delta \log p_{j c}+\varepsilon_{F, c}$. The estimate of growth for country $c$ is thus

$$
\Delta \log q_{F, c}=\frac{1}{w_{F, c}}\left(\hat{\beta}_{F} \Delta \log Q_{c}+\sum_{j=1}^{9} \hat{\pi}_{F, j} \Delta \log p_{j c}\right)+\Delta \log Q_{c},
$$

where $\hat{\beta}_{F}$ and $\hat{\pi}_{F, j}$ are estimates from panel B of Table 4 and $w_{F, c}$ is the share of food in country $c$. The corresponding volume is $q_{F, c, t+1}=\exp \left(\log q_{F, c, t}+\Delta \log q_{F, c}\right)$.

We start with a set of income and price projections based on information available before the onset of the pandemic in 2020. These are the historical growth rates from 2011 to 2017, using data from the ICP (World Bank, 2013, 2020). Using the above procedure, we obtain the baseline food projections. Next, we use the same approach with the same price projections, but now with more recent income-growth projections that were made after the onset of the pandemic, to generate a second set of food forecasts. The income projections are from the World Economic Outlook of the IMF (2021). The order-of-magnitude effect of the pandemic on food consumption can be identified based on the different information sets, that is, by the difference between the two sets of demand projections. This approach has the advantage of allowing for the impact of competing demands of non-food commodities via the working of the cross-price effects and the budget constraint. A further advantage is the allowance for heterogeneity as the income and price projections are country specific, as are the elasticities. $^{19}$

Panel C of Figure 9 shows that COVID-19 is projected to hit poorer countries substantially more than rich ones. Roughly speaking, the pandemic have little or no effect on food demand in countries in the top quartile, while in the other countries, food is lower than otherwise by something like 10 percent. The confidence bands for the effects reveal more certainty for the poorer countries, because with food expenditure absorbing much of income, there is less scope for behaviour to differ substantially across countries. Based on the confidence bands, the lower consumption is statistically significant in the second, third and

\footnotetext{
${ }^{19}$ For further details of the projections, see Appendix A6.
} 
fourth quartiles. ${ }^{20}$ Implications for the global food market can be examined using the United Nations (2019)'s population projections to convert from per capita demands to total. Table 14 contains the results for each quartile, in terms of growth rates (panel A) and shares of each quartile in global demand (panel B). This reveals again the distinct distributional impact of the pandemic, with the richest countries increasing their share of the global market at the expense of poorer economies (column 5 of panel B).

Before concluding this subsection, it is to be emphasized that the projections should not be taken as precise forecasts, but an illustration of the use of the demand model for a counterfactual scenario analysis of income shocks from the pandemic. We isolated the role of the income shocks on food consumption and took the other drivers of demand, such as commodity price changes, social-distancing measures, resurgence of the disease and the efficacy of vaccines, as being unchanged between the two scenarios. Taken individually, these effects could influence food in either direction, so their joint impact is ambiguous and it is not possible to determine whether our projections over- or under-estimate the effects of COVID-19 on food demand.

\section{Generalisations}

In the above, the same demand functions apply to all countries, so differences in consumption patterns stem from different incomes and prices only. In order to relax this requirement, we explore generalisations in which the coefficients of the demand equations differ across countries. This can be interpreted as allowing for non-economic determinants, including the possibility of different tastes. These generalisations are a type of robustness check.

We proceed in four steps. First, rather than comparing consumption in each country to the global counterpart, we now consider differences between groups of countries by comparing to quartile means. Retracing the steps of Section 5, this leads to four intercepts (one for each quartile) in each equation, rather than a single intercept. As discussed in Appendix A7, the main difference in the results is that relative to the all-country model, many of the income coefficients now become insignificantly different from zero, implying that the income elasticities move closer to unity. The reason is that a substantial part of the global income variability stems from the between-quartile component. The quartile intercepts are highly

\footnotetext{
${ }^{20}$ The confidence bands are constructed on the basis of the estimation uncertainty of the demand equations, not the income and price projections; allowing for the latter would increase the width of the bands.
} 
correlated with income, causing much of the effects of income to be transferred from the coefficients of the income variable to the intercepts.

Secondly, as a variation of the above approach, we allow the income coefficients to vary across quartiles, while keeping intercepts and Slutsky coefficients the same. As shown in Appendix A7, this again results in many of the income coefficient being insignificant; and there is no particular pattern in these coefficients across countries. A third generalisation allows the demand equations for each quartile to differ across countries in all respects. The intercepts, income and Slutsky coefficients all differ by estimating a separate system for each quartile. Again, many of the income coefficients become insignificant. Additionally, the standard errors of the Slutsky coefficients are substantially higher than before, due to the smaller sample size available for each quartile. For details, see Appendix A7. Finally, we estimated separate systems for the rich-country group (comprising those countries with incomes above the global mean) and the poor (those with below-mean incomes). Here, there are the same problems as for the separate-quartile estimates. Appendix A7 contains details.

In view of these results, it seems reasonable to conclude that the estimates of the allcountry model -- the same demand equations for all countries -- are preferred to the generalisations.

\section{Concluding Comments}

This paper has three objectives: First, to draw attention to the use of the differential approach for the analysis of consumption patterns across countries. Recent research has emphasised the importance of demand-side influences on the long-term structure of economies. Consumption patterns in different countries can be used to identify these effects and several models are available for this purpose, including the CES and its generalisations, the linear expenditure system and the almost ideal demand model. Overlooked thus far is the differential demand approach (Theil, 1980). The paper demonstrated the approach is worthy of further attention: It is attractive because of its consistency with utility-maximisation theory in full generality, aggregation properties, the ease of hypothesis testing, and its transparent simplicity. We reviewed the foundations of the approach, as well as previous applications to cross-country data, and suggested a novel way of implementation that offers advantages.

The second objective of the paper is to estimate the income and price sensitivity of consumption patterns with recent cross-country data. We used the 2017 round of the World Bank's International Comparison Program, released in 2020, and referring to 176 countries ranging from the richest ones in the West to the poorest African countries, making for great 
dispersion. Average per capita income (as measured by total consumption) of countries in the richest quartile is about 17 times that of countries in the bottom quartile, and the share of income spent on food ranges from less than 10 percent to more than 50 percent. Dividing consumption into 9 broad categories of goods and services, we demonstrated that many of the substantial cross-country disparities can be understood with the differential demand model. Specifically, global consumption patterns obey the law of demand (demand curves slope down) and Engel's law, and the substitution effects of price changes appear to be symmetric. Prices are less dispersed than quantities, reflecting price stickiness due to menu costs and other impediments to price flexibility. The own-price effects were estimated with reasonable precision, but there were difficulties with the cross-price effects. We investigated a more parsimonious approach with an additive utility function, but the evidence firmly rejected this restriction. Food has the lowest income elasticity and recreation the highest, which agrees with economic intuition. The (own) price elasticities are all negative, and the majority less than unity, which is reason for broad aggregates; recreation is the most price elastic. Income was found to be the dominant determinant of cross-country consumption differences, substantially more important than prices; this was especially true for food consumption.

An index of the quality of consumption across countries was constructed using a revealed-preference approach based on estimates of our demand model. The index uses the luxury-necessity distinction to measure quality by the covariation between the income elasticities and consumption. The quality of consumption and its dual price (the covariance of the elasticities with prices) both increase with income and self-reported happiness, as expected. The higher price of quality in richer countries means luxuries are relatively more expensive, which has a progressive effect on the distribution of income, although this effect is modest. Quality demand curves indicated quality is highly price inelastic.

In view of the importance of food in the consumption basket of many countries, especially those of the poor, the third objective of the paper is to investigate in detail the nature of food demand. We found that food expenditure increases with income until per capita income reaches about $\$ U S 33,000$ and falls thereafter, that is, food becomes an inferior good for "sufficiently rich" consumers, those with incomes greater than 70 percent of that of Bermuda - the richest. But caution is appropriate, and more research required before confidently declaring food to be inferior. A further result for food was support for the so-called strong version of Engel's law, according to which a 10-percentage point fall in the food budget share is associated with a doubling of income. This empirical law is useful in using the food share as a convenient (inverse) measure of affluence. As an illustration of the use of the food demand 
equation, we developed projections of the impact of COVID-19. Poorer countries' food consumption is likely to be harder hit by the pandemic.

In summary, our findings indicate that the substantial diversity of global consumption patterns can be, to a large degree, understood with a simple utility-maximising approach. Differences in incomes and prices substantially drive consumption disparities, with income playing a particularly important role, especially in the case of food.

\section{References}

Barnett, W. A. (1979). "Theoretical Foundations for the Rotterdam Model." Review of Economic Studies 45: 109-130.

Barnett, W. A. (1984). "On the Flexibility of the Rotterdam Model: A First Empirical Look." European Economic Review 24: 285-89.

Barten, A. P. (1964). "Consumer Demand Functions under Conditions of Almost Additive Preferences." Econometrica 32: 1-38.

Barten, A. P. (1989). "Toward a Levels Version of the Rotterdam and Related Demand Systems." In B. Cornet and H. Tulkens (eds) Contributions to Operations Research and Economics: The Twentieth Anniversary of CORE. Cambridge, Mass.: MIT Press. Pp. 441-65.

Beckman, J., and A. M. Countryman (2021). "The Importance of Agriculture in the Economy: Impacts from COVID-19”. American Journal of Agricultural Economics 103: 15951611.

Boppart, T. (2014). "Structural Change and the Kaldor Facts in a Growth Model with Relative Price Effects and Non-Gorman Preferences." Econometrica 82: 2167-96.

Caron, J., T. Fally and J. Markusen (2020). "Per Capita Income and the Demand for Skills." Journal of International Economics 123: 103306.

Chen, D. (1999). World Consumption Economics. Singapore: World Scientific.

Christensen, L. R., D. W. Jorgenson and L. J. Lau (1975). "Transcendental Logarithmic Utility Functions." American Economic Review 65: 367-83.

Clements (2019). "Four Laws of Consumption". Economic Record 95: 358-85.

Clements, K. W., and G. Gao (2012). "Quality, Quantity, Spending and Prices.” European Economic Review 56: 1376-91.

Clements, K. W., and G. Gao (2015). "The Rotterdam Demand Model Half a Century On." Economic Modelling 49: 91-103.

Clements, K. W., and Izan (2012). "The Pay Parity Matrix: A Tool for Analysing the Structure of Pay." Applied Economics 44: 4515-25.

Clements, K. W., and J. Si (2018). "Notes on Differential Demand Equations for a Cross Section of Countries." Working paper. Economics Department, UWA Business School.

Clements, K. W., Y. Wu and J. Zhang (2006). "Comparing International Consumption Patterns." Empirical Economics 31: 1-30.

Clements, K. W., and X. Zhao (2009). Economics and Marijuana: Consumption, Pricing and Legalisation. Cambridge: Cambridge University Press.

Comin, D., D. Lashkari, M. Mestieri (2021). "Structural Change with Long-Run Income and Price Effects." Econometrica 89: 311-74.

Costa, D. L. (2001). "Estimating Real Income in the United States from 1888 to 1994: Correcting CPI Bias Using Engel Curves." Journal of Political Economy 109: 12881310. 
Deaton, A. S., and J. Muellbauer (1980). "An Almost Ideal Demand System." American Economic Review 70: 312-26.

Feenstra, R. C. and J. Romalis (2014). "International Prices and Endogenous Quality." Quarterly Journal of Economics 129: 477-527.

Fieler, A. C., M. Eslava and D. Y. Xu (2018). "Trade, Quality Upgrading and Input Linkages: Theory and Evidence from Colombia." American Economic Review 108: 109-46.

Fisher, I. (1922). The Making of Index Numbers: A Study of their Varieties, Tests and Reliability. Houghton Mifflin Company: Boston, New York.

Food and Agriculture Organization (2021). The State of Food Security and Nutrition in the World 2021. Rome: FAO.

Friedman, M. (1962). Price Theory: A Provisional Text. Chicago: Aldine.

Gao, G. (2012). "World Food Demand.” American Journal of Agricultural Economics 94: 2551.

Goldberger, A. S. and T. Gamaletsos (1970). "A Cross-Country Comparison of Consumer Expenditure Patterns." European Economic Review 1: 357-400.

Hallak, J. C. (2010). "A Product-Quality View of the Linder Hypothesis." Review of Economics and Statistics 92: 453-66.

Hamilton B. W. (2001). "Using Engel's Law to Estimate CPI Bias." American Economic Review 91: 619-30.

Herrendorf, B., R. Rogerson and A. Valentinyi (2013). "Two Perspectives on Preferences and Structural Transformation." American Economic Review 103: 2752-89.

Houthakker, H. S. (1957). "An International Comparison of Household Expenditure Patterns, Commemorating the Centenary of Engel's Law." Econometrica 25: 532-51.

Houthakker, H. S. (1960). “Additive Preferences.” Econometrica 28: 244-57.

Houthakker, H. S. (1965). "New Evidence on Demand Elasticities." Econometrica 33: 277-88.

International Monetary Fund (2021). World Economic Outlook. Accessed on $3^{\text {rd }}$ September 2021. Available at: https://www.imf.org/en/Publications/WEO/weodatabase/2021/April/

Kongsamut, P., S. Rebelo and D. Xie (2001). "Beyond Balanced Growth." Review of Economic Studies 68: 869-82.

Kravis, I. B., A. W. Heston and R. Summers (1982). World Product and Income: International Comparisons of Real Gross Product. Baltimore Md.: The John Hopkins University Press.

Laborde, D., W. Martin, and R. Vos (2021). "Impacts of COVID-19 on Global Poverty, Food Security, and Diets: Insights from Global Model Scenario Analysis". Agricultural Economics 52: $375-90$.

Laitinen, K. (1978). "Why is Demand Homogeneity So Often Rejected?" Economics Letters 1: $187-9$.

Lluch, C. and A. A. Powell (1975). "International Comparisons of Expenditure Patterns." European Economic Review 6: 375-303.

Lluch, C., A. A. Powell and R. A. Williams (1977). Patterns in Household Demand and Saving. Oxford: Oxford University Press.

Matsuyama. K. (2019). "Engel's Law in the Global Economy: Demand-Induced Patterns of Structural Change, Innovation and Trade." Econometrica 87: 497-528.

McFadden, D. (1964) "Existence Conditions for Theil-Type Preferences." Unpublished paper, Department of Economics, University of California, Berkeley.

Meade, B., A. Regmi, J. L. Seale, Jr., and A. Muhammad (2014). "New International Evidence on Food Consumption Patterns: A Focus on Cross-Price Effects Based on 2005 International Comparisons." Technical Bulletin 1937. Economic Research Service, United States Department of Agriculture. 
Meisner, J. F. (1979). "The Sad Fate of the Asymptotic Slutsky Symmetry Test for Large Systems." Economics Letters 2: 231-33.

Michail, N. A. (2020). "Convergence of Consumption Patterns in the European Union." Empirical Economics 58: 979-94.

Mountain, D. C. (1988). "The Rotterdam Model: An Approximation in Variable Space." Econometrica 56: 477-84.

Muhammad, A., J. L. Seale, Jr., B. Meade, A. Regmi (2011). "International Evidence on Food Consumption Patterns: An Update Using 2005 International Comparison Program Data." Technical Bulletin 1929. Economic Research Service, United States Department of Agriculture. Revised 2013.

Nakamura, L. (1996). "Is US Economic Performance Really that Bad?" Working Paper No 95, Federal Reserve Bank of Philadelphia.

O'Connell, M., K. Smith and R. Stroud (2021). "The Dietary Impact of the COVID-19 Pandemic". Working paper 21/18. Institute for Fiscal Studies.

Parks, R. W., and A. P. Barten (1973). "A Cross-Country Comparison of the Effects of Prices, Income and Population Composition on Consumption Patterns." Economic Journal 83: 834-52.

Pollak, R. A., and T. J. Wales (1987). "Pooling International Consumption Data." Review of Economics and Statistics 69: 90-99.

Regmi, A., and J. L. Seale, Jr. (2010). "Cross-Price Elasticities of Demand across 114 Countries." Technical Bulletin No. 1925, Economic Research Service, United States Department of Agriculture.

Reimer, J. and T. Hertel (2004). "Estimation of International Demand Behaviour for Use with Input-Output Based Data." Economic Systems Research 16: 347-66.

Rimmer, M. T., and A. A. Powell (1992). "Demand Patterns across the Development Spectrum: Estimates for the AIDADS System." Preliminary Working Paper No. OP-75, Centre of Policy Studies and Impact Project, Monash University.

Seale, J. L., Jr., and A. Regmi (2006). "Modelling International Consumption Patterns." Review of. Income and Wealth 52: 603-24.

Seale, J. L., Jr., and A. Regmi (2009). "International Consumption Patterns: Evidence from the 1996 International Comparison Programme." In S. Ghatak and P. Levine (eds), Development Macroeconomics: Essays in Memory of Anita Ghatak. Routledge, Taylor and Francis Group: London and New York. Pp. 252-99.

Seale, J. L., Jr., A. Regmi and A., J. Bernstein (2003). "International Evidence on Food Consumption Patterns." Technical Bulletin 1904. Economic Research Service, United States Department of Agriculture, Washington, D.C.

Seale, J. L., Jr., and A. A. Solano (2012). "The Changing Demand for Energy in Rich and Poor Countries over 25 Years." Energy Economics 34: 1834-44.

Seale, J. L., Jr., W. E. Walker and I-M. Kim (1991). "The Demand for Energy: Cross-Country Evidence Using the Florida Model.” Energy Economics 13: 33-40.

Selvanathan, E. A. (1991). "Further Results on Aggregation of Differential Demand Equations." Review of Economic Studies 58: 799-805.

Selvanathan, S. (1993). A System-Wide Analysis of International Consumption Patterns. Boston, Dordrecht and London: Kluwer Academic Publishers.

Selvanathan, E. A., and S. Selvanathan (2007). "Another Look at the Identical Tastes Hypothesis on the Analysis of Cross-Country Alcohol Data." Empirical Economics 32: 185-215.

Selvanathan, E. A., S. Selvanathan, L. Wong and M. S. Jayasinghe (2021). "Modelling Regional Consumption Patterns in Australia.” Economic Record 97: 141-56. 
Shannon, C. E. (1948). “A Mathematical Theory of Communication.” Bell System Technical Journal 27: 379-423, 623-56.

Stigler, G. J., and G. S. Becker (1977). "De Gustibus Non Est Disputandum.” American Economic Review 67: 79-90.

Stone, R. (1954). "Linear Expenditure Systems and Demand Analysis: An Application to the Pattern of British Demand." Economic Journal 64: 511-27.

Święcki, T. (2017). "Determinants of Structural Change.” Review of Economic Dynamics 24: 95-131.

Theil, H. (1965). “The Information Approach to Demand Analysis.” Econometrica 33: 67-87.

Theil, H. (1971). Principles of Econometrics. New York: John Wiley and Sons.

Theil, H. (1975/76). Theory and Measurement of Consumer Demand. Two volumes. Amsterdam: North-Holland.

Theil, H. (1980). The System-Wide Approach to Microeconomics. Chicago: The University of Chicago Press.

Theil, H. (1987). "The Econometrics of Demand Systems." Chapter 3 in H. Theil and K. W. Clements, Applied Demand Analysis: Results from System-Wide Approaches. Cambridge, Mass. : Ballinger. Pp. 101-62.

Theil, H. (1996). Studies in Global Econometrics. Dordrecht: Kluwer Academic Publishers. Pp. 95-108.

Theil, H., C-F. Chung and J. L. Seale, Jr (1989). International Evidence on Consumption Patterns. Greenwich, Connecticut: JAI Press, Inc.

Theil, H., and F. E. Suhm (1981). International Consumption Comparisons: A System-Wide Approach. Amsterdam: North-Holland Publishing Company.

United Nations (2019). World Population Prospects. Population Division. Accessed on $3^{\text {rd }}$ September 2021. Available at: https://population.un.org/wpp/

Wohlgenant, M. K. (2021). Market Interrelationships and Applied Demand Analysis: Bridging the Gap between Theory and Empirics in Commodity Markets. Palgrave Studies in Agricultural Economics and Food Policy. Cham, Switzerland: Springer.

Working, H. (1943). "Statistical Laws of Family Expenditure." Journal of the American Statistical Association 38: 43-56.

World Bank (2013). Measuring the Real Size of the World Economy. World Bank: Washington, D. C.

World Bank (2020). "International Comparisons Program.” Accessed on 10 $0^{\text {th }}$ December 2020. Available at: https://www.worldbank.org/en/programs/icp

World Bank (2021). "World Development Indicators." Accessed on $11^{\text {th }}$ July 2021. Available at: https://datatopics.worldbank.org/world-development-indicators/

World Happiness Report (2021). Accessed on $11^{\text {th }}$ July 2021. Available at: https://worldhappiness.report/ 
Table 1. Income, Food Budget Share and Food Prices, 2017

\begin{tabular}{|c|c|c|c|c|c|c|c|}
\hline \multirow[b]{2}{*}{ Country } & \multirow{2}{*}{$\begin{array}{c}\text { Income } \\
(\mathrm{US}=100)\end{array}$} & \multicolumn{2}{|c|}{ Food } & \multirow[b]{2}{*}{ Country } & \multirow{2}{*}{$\begin{array}{c}\text { Income } \\
(\mathrm{US}=100)\end{array}$} & \multicolumn{2}{|c|}{ Food } \\
\hline & & $\begin{array}{c}\text { Budget } \\
\text { share }(\%) \\
\text { (3) }\end{array}$ & $\begin{array}{c}\text { Relative } \\
\text { price } \\
(4)\end{array}$ & & & $\begin{array}{c}\text { Budget } \\
\text { share }(\%) \\
(7)\end{array}$ & $\begin{array}{c}\text { Relative } \\
\text { price } \\
(8)\end{array}$ \\
\hline \multicolumn{4}{|c|}{ A. First quartile } & \multicolumn{4}{|c|}{ B. Second quartile } \\
\hline 1. Bermuda & 107.0 & 12.3 & 11.2 & 45. Bahamas, The & 41.0 & 12.7 & 4.0 \\
\hline 2. Luxembourg & 104.9 & 13.0 & -5.4 & 46. Panama & 40.8 & 19.2 & 47.9 \\
\hline 3. United States & 100.0 & 7.3 & 0.0 & 47. Slovak Republic & 40.7 & 19.3 & 19.3 \\
\hline 4. Hong Kong SAR & 95.6 & 11.0 & 42.7 & 48. Latvia & 40.0 & 21.8 & 23.6 \\
\hline 5. Switzerland & 89.6 & 11.0 & 14.2 & 49. Bahrain & 39.6 & 13.5 & 39.3 \\
\hline 6. Iceland & 83.0 & 12.5 & 12.2 & 50. Curaçao & 39.3 & 11.3 & 20.9 \\
\hline 7. Australia & 82.9 & 10.6 & 30.0 & 51. Mauritius & 39.3 & 29.1 & 40.8 \\
\hline 8. Austria & 82.1 & 10.2 & 17.3 & 52. Anguilla & 38.4 & 16.5 & 33.5 \\
\hline 9. Norway & 82.0 & 10.7 & 27.6 & 53. Trinidad and Tobago & 37.5 & 15.2 & 35.9 \\
\hline 10. Denmark & 80.2 & 10.5 & 7.9 & 54. Kuwait & 37.3 & 12.1 & 26.2 \\
\hline 11. United Kingdom & 76.5 & 9.0 & 9.7 & 55. Romania & 37.3 & 28.0 & 20.3 \\
\hline 12. Cayman Islands & 76.5 & 8.6 & 15.8 & 56. Montserrat & 37.2 & 17.2 & 68.0 \\
\hline 13. Germany & 76.5 & 10.8 & 6.4 & 57. Hungary & 37.0 & 20.7 & 24.2 \\
\hline 14. Finland & 76.0 & 12.1 & 14.6 & 58. Argentina & 36.7 & 22.0 & 30.8 \\
\hline 15. Singapore & 74.2 & 7.7 & 47.1 & 59. Montenegro & 36.7 & 28.8 & 25.5 \\
\hline 16. Netherlands & 71.0 & 10.6 & -0.9 & 60. Turkey & 36.4 & 18.9 & 41.7 \\
\hline 17. Sweden & 70.8 & 10.9 & 3.8 & 61. Malaysia & 35.4 & 21.4 & 45.4 \\
\hline 18. France & 70.4 & 12.7 & 14.4 & 62. St. Kitts and Nevis & 34.2 & 19.2 & 35.6 \\
\hline 19. Canada & 68.4 & 10.4 & 11.2 & 63. Russian Federation & 33.0 & 29.0 & 20.7 \\
\hline 20. Belgium & 68.0 & 13.0 & 5.0 & 64. Uruguay & 32.7 & 20.5 & 28.2 \\
\hline 21. Taiwan, China & 67.5 & 14.7 & 60.0 & 65. Chile & 32.7 & 18.0 & 23.2 \\
\hline 22. Cyprus & 64.4 & 15.7 & 22.3 & 66. Costa Rica & 32.5 & 17.5 & 43.3 \\
\hline 23. New Zealand & 61.0 & 16.5 & 32.9 & 67. Barbados & 31.4 & 12.3 & 27.5 \\
\hline 24. Ireland & 60.3 & 11.0 & 20.4 & 68. Bulgaria & 31.0 & 21.6 & 33.3 \\
\hline 25. Italy & 59.7 & 15.4 & 9.5 & 69. Brunei Darussalam & 30.6 & 14.5 & 44.0 \\
\hline 26. Malta & 59.5 & 13.2 & 34.7 & 70. British Virgin Islands & 30.2 & 25.6 & 21.4 \\
\hline 27. UAE & 59.2 & 11.4 & 32.4 & 71. Oman & 30.0 & 18.8 & 26.0 \\
\hline 28. Japan & 57.8 & 14.0 & 30.1 & 72. Kazakhstan & 28.2 & 26.6 & 14.2 \\
\hline 29. Qatar & 56.4 & 8.2 & 17.9 & 73. Grenada & 27.6 & 22.1 & 41.0 \\
\hline 30. Israel & 56.3 & 15.0 & 20.6 & 74. Mexico & 27.2 & 25.2 & 19.4 \\
\hline 31. Spain & 55.0 & 13.7 & 1.1 & 75. Antigua and Barbuda & 25.7 & 18.8 & 32.7 \\
\hline 32. Korea, Rep. & 50.0 & 11.1 & 59.8 & 76. Serbia & 24.0 & 28.7 & 23.3 \\
\hline 33. Portugal & 49.9 & 17.0 & 13.8 & 77. Belarus & 23.8 & 33.5 & 22.3 \\
\hline 34. Lithuania & 48.8 & 24.3 & 19.9 & 78. Dominican Republic & 23.5 & 29.7 & 38.4 \\
\hline 35. Sint Maarten & 48.3 & 8.8 & 20.2 & 79. Bosn. \& Herz. & 22.5 & 34.3 & 20.0 \\
\hline 36. Slovenia & 47.5 & 16.1 & 8.8 & 80. Turks \& Caicos Is. & 22.1 & 15.8 & 27.1 \\
\hline 37. Greece & 47.3 & 19.0 & 21.2 & 81. Egypt, Arab Rep. & 21.8 & 39.8 & 45.5 \\
\hline 38. Czech Republic & 47.0 & 19.9 & 16.1 & 82. Jamaica & 21.7 & 26.6 & 55.8 \\
\hline 39. Aruba & 46.8 & 8.6 & 33.5 & 83. Albania & 21.1 & 40.1 & 28.8 \\
\hline 40. Saudi Arabia & 45.3 & 17.0 & 38.1 & 84. Brazil & 20.8 & 17.5 & 9.2 \\
\hline 41. Croatia & 44.2 & 22.0 & 32.1 & 85. Thailand & 20.8 & 26.9 & 42.2 \\
\hline 42. Estonia & 44.2 & 22.4 & 19.9 & 86. Colombia & 20.5 & 19.5 & 29.6 \\
\hline 43. Poland & 44.1 & 19.3 & 19.4 & 87. Equatorial Guinea & 20.4 & 36.0 & 36.5 \\
\hline 44. Seychelles & 42.8 & 19.2 & 60.7 & 88. North Macedonia & 20.2 & 33.8 & 15.6 \\
\hline Mean & 65.9 & 13.4 & 21.1 & Mean & 30.9 & 22.7 & 30.7 \\
\hline Median & 62.7 & 12.4 & 18.6 & Median & 32.0 & 21.0 & 28.5 \\
\hline S.D & 17.3 & 4.1 & 15.7 & S.D & 7.0 & 7.4 & 12.3 \\
\hline
\end{tabular}


Table 1. Income, Food Budget Share and Food Prices, 2017 (cont'd)

\begin{tabular}{|c|c|c|c|c|c|c|c|}
\hline \multirow[b]{2}{*}{ Country } & \multirow{2}{*}{$\begin{array}{c}\text { Income } \\
(\mathrm{US}= \\
100)\end{array}$} & \multicolumn{2}{|c|}{ Food } & \multirow[b]{2}{*}{ Country } & \multirow{2}{*}{$\begin{array}{c}\text { Income } \\
\text { (US = } \\
100)\end{array}$} & \multicolumn{2}{|c|}{ Food } \\
\hline & & $\begin{array}{c}\text { Budget } \\
\text { share (\%) }\end{array}$ & $\begin{array}{l}\text { Relative } \\
\text { price }\end{array}$ & & & $\begin{array}{c}\text { Budget } \\
\text { share (\%) }\end{array}$ & $\begin{array}{l}\text { Relative } \\
\text { price }\end{array}$ \\
\hline (1) & (2) & (3) & (4) & (5) & (6) & (7) & (8) \\
\hline \multicolumn{4}{|c|}{ C. Third quartile } & \multicolumn{4}{|c|}{ D. Fourth quartile } \\
\hline 89. Tunisia & 19.9 & 24.3 & 33.8 & 133. India & 7.7 & 28.3 & 31.4 \\
\hline 90. Sri Lanka & 19.8 & 28.0 & 66.1 & 134. Lao PDR & 7.5 & 47.3 & 28.4 \\
\hline 91. Dominica & 19.0 & 18.3 & 35.3 & 135. Uzbekistan & 7.4 & 41.7 & 27.0 \\
\hline 92. Azerbaijan & 18.4 & 34.5 & 18.9 & 136. Angola & 7.4 & 42.9 & 39.6 \\
\hline 93. St. Vincent \& the Gr. & 18.4 & 24.3 & 37.5 & 137. Nigeria & 7.3 & 59.0 & 35.1 \\
\hline 94. South Africa & 18.4 & 22.1 & 26.6 & 138. Lesotho & 5.8 & 33.3 & 23.3 \\
\hline 95. Namibia & 18.2 & 24.4 & 19.2 & 139. Cambodia & 5.8 & 48.7 & 25.3 \\
\hline 96. Peru & 17.4 & 21.8 & 28.9 & 140. Sudan & 5.6 & 50.1 & 31.8 \\
\hline 97. Georgia & 17.4 & 28.7 & 27.2 & 141. Bangladesh & 5.4 & 52.9 & 22.5 \\
\hline 98. Fiji & 17.2 & 44.0 & 32.1 & 142. São Tomé \& Pr. & 5.3 & 57.9 & 20.9 \\
\hline 99. Maldives & 17.1 & 16.7 & 19.8 & 143. Ghana & 5.2 & 28.6 & 65.8 \\
\hline 100. Ukraine & 17.0 & 42.4 & 31.1 & 144. Comoros & 5.1 & 49.6 & 35.4 \\
\hline 101. Iran, Islamic Rep. & 16.9 & 20.1 & 39.5 & 145. Senegal & 4.9 & 47.0 & 35.1 \\
\hline 102. Armenia & 16.6 & 49.3 & 19.2 & 146. Cameroon & 4.9 & 37.1 & 27.5 \\
\hline 103. Paraguay & 16.3 & 28.0 & 13.9 & 147. Côte d'Ivoire & 4.7 & 48.5 & 26.0 \\
\hline 104. Suriname & 15.9 & 38.4 & 41.5 & 148. Congo, Rep. & 4.7 & 39.6 & 45.9 \\
\hline 105. Botswana & 15.3 & 54.6 & 17.2 & 149. Myanmar & 4.2 & 55.4 & 25.8 \\
\hline 106. Ecuador & 14.9 & 24.2 & 27.2 & 150. Zimbabwe & 4.1 & 37.5 & 22.0 \\
\hline 107. China & 14.8 & 16.9 & 34.8 & 151. Nepal & 4.1 & 62.1 & 25.2 \\
\hline 108. Moldova & 14.5 & 31.9 & 13.4 & 152. Tanzania & 4.0 & 50.0 & 20.0 \\
\hline 109. Jordan & 14.2 & 25.9 & 34.2 & 153. Tajikistan & 4.0 & 41.0 & 24.8 \\
\hline 110. Eswatini & 14.0 & 32.4 & 29.5 & 154. Gambia, The & 3.7 & 50.0 & 39.8 \\
\hline 111. El Salvador & 13.9 & 30.7 & 21.5 & 155. Mauritania & 3.7 & 58.6 & 30.7 \\
\hline 112. Indonesia & 13.3 & 36.1 & 45.3 & 156. Guinea & 3.6 & 62.2 & 34.9 \\
\hline 113. Algeria & 13.3 & 36.7 & 49.9 & 157. Haiti & 3.5 & 55.8 & 25.0 \\
\hline 114. Bhutan & 12.2 & 36.4 & 32.7 & 158. Benin & 3.5 & 45.4 & 33.8 \\
\hline 115. Mongolia & 11.8 & 36.2 & 23.3 & 159. Zambia & 3.2 & 38.2 & 24.7 \\
\hline 116. Cabo Verde & 11.7 & 27.3 & 20.9 & 160. Uganda & 3.1 & 36.2 & 23.2 \\
\hline 117. Bolivia & 11.7 & 35.2 & 17.0 & 161. Mali & 3.1 & 50.1 & 16.2 \\
\hline 118. Philippines & 11.6 & 40.4 & 27.1 & 162. Rwanda & 3.1 & 38.5 & 19.5 \\
\hline 119. Belize & 11.0 & 19.6 & 27.6 & 163. Sierra Leone & 3.0 & 47.1 & 30.2 \\
\hline 120. W. Bank \& Gaza & 10.7 & 30.9 & 38.1 & 164. Guinea-Bissau & 2.6 & 75.6 & 13.6 \\
\hline 121. Guyana & 10.7 & 28.3 & 28.9 & 165. Togo & 2.2 & 46.7 & 43.5 \\
\hline 122. Iraq & 10.5 & 28.4 & 23.4 & 166. Ethiopia & 2.2 & 44.9 & 34.7 \\
\hline 123. Gabons & 10.2 & 38.7 & 34.2 & 167. Madagascar & 2.1 & 58.1 & 21.7 \\
\hline 124. Vietnam & 10.0 & 29.4 & 34.0 & 168. Chad & 2.1 & 60.4 & 20.0 \\
\hline 125. Morocco & 9.9 & 33.7 & 30.8 & 169. Burkina Faso & 2.0 & 54.9 & 21.5 \\
\hline 126. Nicaragua & 9.2 & 30.9 & 34.3 & 170. Liberia & 2.0 & 29.7 & 62.9 \\
\hline 127. St. Lucia & 9.1 & 15.9 & 22.7 & 171. Mozambique & 1.7 & 57.0 & 19.7 \\
\hline 128. Honduras & 9.0 & 33.1 & 24.1 & 172. Malawi & 1.7 & 51.8 & 6.3 \\
\hline 129. Djibouti & 8.4 & 30.2 & 29.1 & 173. Congo, Dem. Rep. & 1.6 & 62.5 & 21.2 \\
\hline 130. Kenya & 8.1 & 38.6 & 36.1 & 174. Central Afri. Rep. & 1.4 & 62.7 & 22.3 \\
\hline 131. Pakistan & 8.1 & 33.1 & 33.1 & 175. Burundi & 1.3 & 58.0 & 30.5 \\
\hline 132. Kyrgyz Rep. & 7.8 & 43.8 & 21.1 & 176. Niger & 1.2 & 43.0 & 38.9 \\
\hline Mean & 13.7 & 31.0 & 29.6 & Mean & 3.9 & 48.8 & 28.9 \\
\hline Median & 14.0 & 30.8 & 29.0 & Median & 3.7 & 49.2 & 25.9 \\
\hline S.D & 3.6 & 8.6 & 9.8 & S.D & 1.8 & 10.3 & 11.0 \\
\hline
\end{tabular}

Note: Income is the sum of per capita real consumption expenditures on the nine commodities, $\sum_{i=1}^{9} q_{i}$. The budget share of food $(i=1)$ is its expenditure $\left(p_{1} q_{1}\right)$ as a proportion of total, that is, $w_{i c}=\frac{p_{1} q_{1}}{\sum_{i=1}^{9} p_{i} q_{i}}$. The relative price of food is $\log p_{1 c}-$ $\sum_{i=1}^{9} w_{i c} \log p_{i c}$, where $p_{i c}$ indicates the PPP price of item $i$. These measures are constructed using 2017 ICP data provided by the World Bank (2020). 
Table 2. Budget Shares and Dispersion

\begin{tabular}{|c|c|c|c|c|c|}
\hline \multirow[b]{2}{*}{ Commodity } & \multicolumn{4}{|c|}{ Quartile } & \multirow[b]{2}{*}{$\begin{array}{c}\text { All } \\
\text { countries } \\
(6)\end{array}$} \\
\hline & $\begin{array}{c}\text { Richest } \leftarrow \\
\text { First } \\
\text { (2) }\end{array}$ & $\begin{array}{c}\text { Second } \\
\text { (3) }\end{array}$ & $\begin{array}{l}\text { Third } \\
\text { (4) }\end{array}$ & $\begin{array}{c}\rightarrow \text { Poorest } \\
\text { Fourth } \\
(5)\end{array}$ & \\
\hline \multicolumn{6}{|c|}{ A. Budget shares } \\
\hline 1. Food & 13.37 & 22.72 & 31.02 & 48.77 & 28.97 \\
\hline 2. Clothing & 3.57 & 3.8 & 4.63 & 4.64 & 4.16 \\
\hline 3. Housing & 19.6 & 17.49 & 14.46 & 11.19 & 15.68 \\
\hline 4. Furnishings & 4.25 & 4.84 & 4.91 & 3.9 & 4.47 \\
\hline 5. Health & 11.1 & 8.62 & 7.18 & 4.38 & 7.82 \\
\hline 6. Education & 7.62 & 7.44 & 7.9 & 6.77 & 7.43 \\
\hline 7. Restaurants & 7.16 & 5.51 & 3.77 & 3.01 & 4.86 \\
\hline 8. Recreation & 7.78 & 5.55 & 3.5 & 2.24 & 4.77 \\
\hline 9. Miscellaneous & 25.56 & 24.03 & 22.65 & 15.09 & 21.83 \\
\hline \multicolumn{6}{|c|}{ B. Price and quantity dispersion } \\
\hline Price S.D & 23.07 & 31.53 & 33.76 & 36.15 & 31.13 \\
\hline Quantity S.D & 66.26 & 66.75 & 68.39 & 79.65 & 70.26 \\
\hline Price-quantity correlation & -37.22 & -16.54 & 4.51 & 41.95 & -1.62 \\
\hline
\end{tabular}

Notes:

1. The dispersion measures of panel B are Divisia (or budget-share weighted) moments, which, for country $c$, are defined as follows:

(i) The price standard deviation is $\sqrt{V_{c}^{p p}}=\sqrt{\sum_{i=1}^{9} w_{i c}\left(\log p_{i c}-\log P_{c}\right)^{2}}$, where $\log P_{c}=$ $\sum_{i=1}^{9} w_{i c} \log p_{i c}$ is the Divisia price index.

(ii) The quantity standard deviation is $\sqrt{V_{c}^{q q}}=\sqrt{\sum_{i=1}^{9} w_{i c}\left(\log q_{i c}-\log Q_{c}\right)^{2}}$, where $\log Q_{c}=\sum_{i=1}^{9} w_{i c} \log q_{i c}$ is the Divisia quantity index.

(iii) The price-quantity correlation is $\rho_{c}=\frac{V_{c}^{p q}}{\sqrt{V_{c}^{p p} V_{c}^{q q}}}$, with $V_{c}^{p q}=\sum_{i=1}^{9} w_{i c}\left(\log p_{i c}-\right.$ $\left.\log P_{c}\right)\left(\log q_{i c}-\log Q_{c}\right)$ the corresponding covariance. The ICP numeraire country, the United States, is omitted from the correlation for the richest quartile and all countries as its PPP prices are all unitary.

2. Income quartiles are defined in Table 1. All entries are cross-country averages, multiplied by 100. 
Table 3. The Covariation of Quantities and Prices

\begin{tabular}{|c|c|c|c|c|c|c|c|c|c|}
\hline \multirow{2}{*}{$\begin{array}{c}\text { Quantity relative to } \\
\text { average } \\
\text { (1) }\end{array}$} & \multicolumn{9}{|c|}{ Price relative to average } \\
\hline & $\begin{array}{c}\text { Above } \\
\text { (2) }\end{array}$ & $\begin{array}{c}\text { Below } \\
\text { (3) }\end{array}$ & $\begin{array}{l}\text { Total } \\
\text { (4) }\end{array}$ & $\begin{array}{c}\text { Above } \\
\text { (5) }\end{array}$ & $\begin{array}{c}\text { Below } \\
\text { (6) }\end{array}$ & $\begin{array}{l}\text { Total } \\
\text { (7) }\end{array}$ & $\begin{array}{c}\text { Above } \\
\text { (8) }\end{array}$ & $\begin{array}{c}\text { Below } \\
\text { (9) }\end{array}$ & $\begin{array}{l}\text { Total } \\
(10)\end{array}$ \\
\hline & \multicolumn{9}{|c|}{ A. $\operatorname{Poor}(C=88)$} \\
\hline & \multicolumn{3}{|c|}{ A1. Food } & \multicolumn{3}{|c|}{ A2. Clothing } & \multicolumn{3}{|c|}{ A3. Housing } \\
\hline Above & $20(22.73)$ & $28(31.82)$ & $48(54.55)$ & $14(15.91)$ & $33(37.5)$ & $47(53.41)$ & $15(17.05)$ & $33(37.5)$ & $48(54.55)$ \\
\hline Below & $20(22.73)$ & $20(22.73)$ & $40(45.45)$ & $22(25)$ & $19(21.59)$ & $41(46.59)$ & $28(31.82)$ & $12(13.64)$ & $40(45.45)$ \\
\hline Total & $40(45.45)$ & $48(54.55)$ & $88(100)$ & $36(40.91)$ & $52(59.09)$ & $88(100)$ & $43(48.86)$ & $45(51.14)$ & $88(100)$ \\
\hline \multirow[t]{2}{*}{ Measure of association } & \multicolumn{3}{|c|}{$-0.08(0.56)$} & \multicolumn{3}{|c|}{$-0.24(5.07)$} & \multicolumn{3}{|c|}{$-0.39(13.38)$} \\
\hline & \multicolumn{3}{|c|}{ A4. Furnishings } & \multicolumn{3}{|c|}{ A5. Health } & \multicolumn{3}{|c|}{ A6. Education } \\
\hline Above & $15(17.05)$ & $33(37.5)$ & $48(54.55)$ & $15(17.05)$ & $30(34.09)$ & $45(51.14)$ & $16(18.18)$ & $33(37.5)$ & $49(55.68)$ \\
\hline Below & $28(31.82)$ & $12(13.64)$ & $40(45.45)$ & $34(38.64)$ & $9(10.23)$ & $43(48.86)$ & $26(29.55)$ & $13(14.77)$ & $39(44.32)$ \\
\hline Total & $43(48.86)$ & $45(51.14)$ & $88(100)$ & $49(55.68)$ & $39(44.32)$ & $88(100)$ & $42(47.73)$ & $46(52.27)$ & $88(100)$ \\
\hline \multirow[t]{2}{*}{ Measure of association } & \multicolumn{3}{|c|}{$-0.39(13.38)$} & \multicolumn{3}{|c|}{$-0.46(18.62)$} & \multicolumn{3}{|c|}{$-0.34(10.17)$} \\
\hline & \multicolumn{3}{|c|}{ A7. Restaurants } & \multicolumn{3}{|c|}{ A8. Recreation } & \multicolumn{3}{|c|}{ A9. All commodities } \\
\hline Above & $22(25)$ & $27(30.68)$ & $49(55.68)$ & $16(18.18)$ & $29(32.95)$ & $45(51.14)$ & $147(20.88)$ & $236(33.52)$ & $383(54.4)$ \\
\hline Below & $23(26.14)$ & $16(18.18)$ & $39(44.32)$ & $29(32.95)$ & $14(15.91)$ & $43(48.86)$ & $196(27.84)$ & $125(17.76)$ & $321(45.6)$ \\
\hline Total & $45(51.14)$ & $43(48.86)$ & $88(100)$ & $45(51.14)$ & $43(48.86)$ & $88(100)$ & $343(48.72)$ & $361(51.28)$ & $704(100)$ \\
\hline Measure of association & \multicolumn{3}{|c|}{$-0.14(1.72)$} & \multicolumn{3}{|c|}{$-0.32(9.01)$} & \multicolumn{3}{|c|}{$-0.23(37.24)$} \\
\hline
\end{tabular}


Table 3. The Covariation of Quantities and Prices (cont'd)

\begin{tabular}{|c|c|c|c|c|c|c|c|c|c|}
\hline \multirow{2}{*}{$\begin{array}{c}\text { Quantity relative to } \\
\text { average } \\
\text { (1) }\end{array}$} & \multicolumn{9}{|c|}{ Price relative to average } \\
\hline & $\begin{array}{l}\text { Above } \\
\text { (2) }\end{array}$ & $\begin{array}{c}\text { Below } \\
\text { (3) }\end{array}$ & $\begin{array}{l}\text { Total } \\
\text { (4) }\end{array}$ & $\begin{array}{c}\text { Above } \\
\text { (5) }\end{array}$ & $\begin{array}{c}\text { Below } \\
(6)\end{array}$ & $\begin{array}{l}\text { Total } \\
\text { (7) }\end{array}$ & $\begin{array}{c}\text { Above } \\
(8)\end{array}$ & $\begin{array}{l}\text { Below } \\
(9)\end{array}$ & $\begin{array}{l}\text { Total } \\
\text { (10) }\end{array}$ \\
\hline & \multicolumn{9}{|c|}{ B. Rich $(C=88)$} \\
\hline & \multicolumn{3}{|c|}{ B1. Food } & \multicolumn{3}{|c|}{ B2. Clothing } & \multicolumn{3}{|c|}{ B3. Housing } \\
\hline Above & $17(19.32)$ & $27(30.68)$ & $44(50)$ & $17(19.32)$ & $27(30.68)$ & $44(50)$ & $17(19.32)$ & $27(30.68)$ & $44(50)$ \\
\hline Below & $27(30.68)$ & $17(19.32)$ & $44(50)$ & $27(30.68)$ & $17(19.32)$ & $44(50)$ & $27(30.68)$ & $17(19.32)$ & $44(50)$ \\
\hline Total & $44(50)$ & $44(50)$ & $88(100)$ & $44(50)$ & $44(50)$ & $88(100)$ & $44(50)$ & $44(50)$ & $88(100)$ \\
\hline \multirow[t]{2}{*}{ Measure of association } & \multicolumn{3}{|c|}{$-0.23(4.66)$} & \multicolumn{3}{|c|}{$-0.27(6.42)$} & \multicolumn{3}{|c|}{$-0.38(12.71)$} \\
\hline & \multicolumn{3}{|c|}{ B4. Furnishings } & \multicolumn{3}{|c|}{ B5. Health } & \multicolumn{3}{|c|}{ B6. Education } \\
\hline Above & $16(18.18)$ & $26(29.55)$ & $42(47.73)$ & $16(18.18)$ & $26(29.55)$ & $42(47.73)$ & $16(18.18)$ & $26(29.55)$ & $42(47.73)$ \\
\hline Below & $28(31.82)$ & $18(20.45)$ & $46(52.27)$ & $28(31.82)$ & $18(20.45)$ & $46(52.27)$ & $28(31.82)$ & $18(20.45)$ & $46(52.27)$ \\
\hline Total & $44(50)$ & $44(50)$ & $88(100)$ & $44(50)$ & $44(50)$ & $88(100)$ & $44(50)$ & $44(50)$ & $88(100)$ \\
\hline \multirow[t]{2}{*}{ Measure of association } & \multicolumn{3}{|c|}{$-0.23(4.66)$} & \multicolumn{3}{|c|}{$-0.63(34.93)$} & \multicolumn{3}{|c|}{$-0.36(11.4)$} \\
\hline & \multicolumn{3}{|c|}{ B7. Restaurants } & \multicolumn{3}{|c|}{ B8. Recreation } & \multicolumn{3}{|c|}{ B9. All commodities } \\
\hline Above & $17(19.32)$ & $26(29.55)$ & $43(48.86)$ & $17(19.32)$ & $26(29.55)$ & $43(48.86)$ & $17(19.32)$ & $26(29.55)$ & $43(48.86)$ \\
\hline Below & $30(34.09)$ & $15(17.05)$ & $45(51.14)$ & $30(34.09)$ & $15(17.05)$ & $45(51.14)$ & $30(34.09)$ & $15(17.05)$ & $45(51.14)$ \\
\hline Total & $47(53.41)$ & $41(46.59)$ & $88(100)$ & $47(53.41)$ & $41(46.59)$ & $88(100)$ & $47(53.41)$ & $41(46.59)$ & $88(100)$ \\
\hline Measure of association & \multicolumn{3}{|c|}{$-0.27(6.42)$} & \multicolumn{3}{|c|}{$-0.37(12.05)$} & \multicolumn{3}{|c|}{$-0.3(63.36)$} \\
\hline
\end{tabular}


Table 3. The Covariation of Quantities and Prices (cont'd)

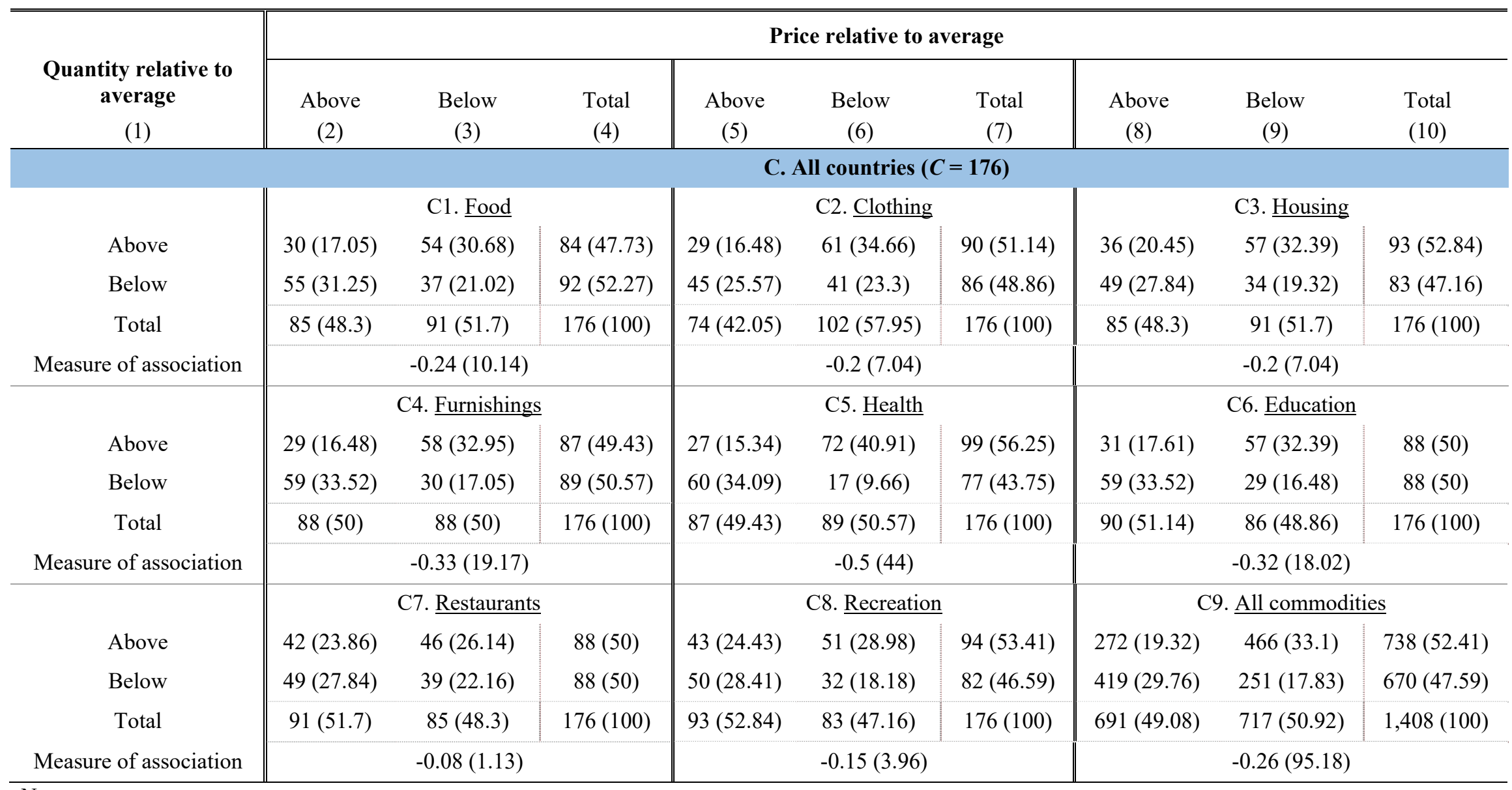

Notes:

1. Poor (rich) countries are those in the two lower (upper) income quartiles.

2. For non-food items, the relative quantity difference is $\Delta \log q_{i c}-\Delta \log Q_{c}$; to allow for a less-than-unity income elasticity of food, its relative quantity difference is defined as $\Delta \log q_{i c}-\frac{1}{2} \Delta \log Q_{c}$. For all items, the relative price difference is $\Delta \log p_{i c}-\Delta \log p_{9 c}$. See notes to Figure 4 for details.

3. In the first 3 rows of each $4 \times 3$ sub-panel, the first entry in each cell is the number of countries for which the relative quantity difference is above/below its cross-country average, classified according to whether the relative price difference is above/below average; the figure in parenthesis in each cell is the corresponding percentage of countries. The figures in the $3 \times 3$ block for "All commodities" (lower right-hand corner) refer to the number of country-commodities.

4. In the fourth row of each $4 \times 3$ sub-panel, the first entry is the measure of association, denoted by $\omega$, which lies in the range [-1,1]. If the inner $2 \times 2$ contingency table takes the form $\left[\begin{array}{ll}a & b \\ c & d\end{array}\right]$, then $\omega=(a d-b c) / \sqrt{(a+b)(a+c)(c+d)(b+b)}$. When quantities and prices are independent, then $a=c$ and $b=d$, so $a d=b c$ and $\omega=$ 0 . The statistic to test the null of independence, $H_{0}: \omega=0$, is $C \times \omega^{2} \sim \chi^{2}$, where $C$ is the number of countries in each group. The figure in parenthesis in the fourth row is $C \times \omega^{2}$. The null is rejected when $C \times \omega^{2}$ is greater than the critical value at the $5 \%$ level of $\chi^{2}(1)=3.84$. Thus, independence is rejected in all cases, except for "Food" in poor countries and "Restaurants" in poor and in all countries. 
Table 4. Cross-Country Demand Equations

\begin{tabular}{|c|c|c|c|c|c|c|c|c|c|c|}
\hline \multirow{2}{*}{$\begin{array}{c}\text { Commodity } i \\
(1) \\
\end{array}$} & \multirow{2}{*}{$\begin{array}{c}\text { Income } \\
\text { coefficient } \\
\beta_{i} \\
(2) \\
\end{array}$} & \multicolumn{9}{|c|}{ Price coefficients } \\
\hline & & $\begin{array}{l}\pi_{1 j} \\
(3) \\
\end{array}$ & $\begin{array}{l}\pi_{2 j} \\
(4) \\
\end{array}$ & $\begin{array}{l}\pi_{3 j} \\
(5) \\
\end{array}$ & $\begin{array}{c}\pi_{4 j} \\
(6)\end{array}$ & $\begin{array}{l}\pi_{5 j} \\
(7)\end{array}$ & $\begin{array}{r}\pi_{6 j} \\
(8) \\
\end{array}$ & $\begin{array}{r}\pi_{7 j} \\
(9) \\
\end{array}$ & $\begin{array}{l}\pi_{8 j} \\
(10)\end{array}$ & $\begin{array}{l}\pi_{9 j} \\
(11) \\
\end{array}$ \\
\hline \multicolumn{11}{|c|}{ A. Homogeneity-constrained } \\
\hline 1. Food & $\begin{array}{r}-11.43 \\
(0.87)\end{array}$ & $\begin{array}{r}-13.81 \\
(3.72)\end{array}$ & $\begin{array}{c}4 . \overline{13} \\
(2.76)\end{array}$ & $\begin{array}{c}3.18 \\
(4.25)\end{array}$ & $\begin{array}{c}6.57 \\
(3.37)\end{array}$ & $\begin{array}{c}2.23 \\
(1.79)\end{array}$ & $\begin{array}{c}4.79 \\
(2.95)\end{array}$ & $\begin{array}{c}0.19 \\
(1.93)\end{array}$ & $\begin{array}{l}-2.87 \\
(2.63)\end{array}$ & $\begin{array}{c}-4.41 \\
(5.09)\end{array}$ \\
\hline 2. Clothing & $\begin{array}{l}-0.57 \\
(0.24)\end{array}$ & $\begin{array}{c}2.82 \\
(1.05)\end{array}$ & $\begin{array}{l}-3.61 \\
(0.79)\end{array}$ & $\begin{array}{c}1.61 \\
(1.20)\end{array}$ & $\begin{array}{l}-2.06 \\
(0.96)\end{array}$ & $\begin{array}{l}-1.67 \\
(0.51)\end{array}$ & $\begin{array}{c}1.26 \\
(0.81)\end{array}$ & $\begin{array}{l}-0.64 \\
(0.58)\end{array}$ & $\begin{array}{c}0.45 \\
(0.76)\end{array}$ & $\begin{array}{c}1.85 \\
(1.43)\end{array}$ \\
\hline 3. Housing & $\begin{array}{c}2.91 \\
(0.65)\end{array}$ & $\begin{array}{c}3.52 \\
(2.73)\end{array}$ & $\begin{array}{l}-3.79 \\
(2.13)\end{array}$ & $\begin{array}{l}-6.81 \\
(3.25)\end{array}$ & $\begin{array}{l}-3.16 \\
(2.44)\end{array}$ & $\begin{array}{c}2.8 \\
(1.36)\end{array}$ & $\begin{array}{c}2.05 \\
(2.30)\end{array}$ & $\begin{array}{c}3.46 \\
(1.48)\end{array}$ & $\begin{array}{l}-0.97 \\
(1.98)\end{array}$ & $\begin{array}{c}2.9 \\
(3.85)\end{array}$ \\
\hline 4. Furnishings & $\begin{array}{c}0.23 \\
(0.18)\end{array}$ & $\begin{array}{c}-0.2 \\
(0.74)\end{array}$ & $\begin{array}{c}0.3 \\
(0.56)\end{array}$ & $\begin{array}{c}1.66 \\
(0.88)\end{array}$ & $\begin{array}{l}-5.47 \\
(0.68)\end{array}$ & $\begin{array}{c}1.69 \\
(0.35)\end{array}$ & $\begin{array}{c}1.01 \\
(0.61)\end{array}$ & $\begin{array}{l}-0.56 \\
(0.40)\end{array}$ & $\begin{array}{l}-0.12 \\
(0.51)\end{array}$ & $\begin{array}{c}1.68 \\
(1.02)\end{array}$ \\
\hline 5. Health & $\begin{array}{c}1.39 \\
(0.30)\end{array}$ & $\begin{array}{l}-1.79 \\
(1.27)\end{array}$ & $\begin{array}{c}1.01 \\
(0.97)\end{array}$ & $\begin{array}{c}-0.4 \\
(1.44)\end{array}$ & $\begin{array}{c}1.15 \\
(1.20)\end{array}$ & $\begin{array}{c}-8.17 \\
(0.61)\end{array}$ & $\begin{array}{c}2.16 \\
(1.00)\end{array}$ & $\begin{array}{c}0.73 \\
(0.71)\end{array}$ & $\begin{array}{c}2.75 \\
(0.94)\end{array}$ & $\begin{array}{c}2.56 \\
(1.75)\end{array}$ \\
\hline 6. Education & $\begin{array}{l}-0.04 \\
(0.35)\end{array}$ & $\begin{array}{c}1.17 \\
(1.50)\end{array}$ & $\begin{array}{c}0.9 \\
(1.18)\end{array}$ & $\begin{array}{c}0.43 \\
(1.68)\end{array}$ & $\begin{array}{l}-1.19 \\
(1.36)\end{array}$ & $\begin{array}{c}0.76 \\
(0.72)\end{array}$ & $\begin{array}{l}-7.69 \\
(1.22)\end{array}$ & $\begin{array}{l}-0.39 \\
(0.79)\end{array}$ & $\begin{array}{c}2.58 \\
(1.11)\end{array}$ & $\begin{array}{c}3.43 \\
(2.08)\end{array}$ \\
\hline 7. Restaurants & $\begin{array}{c}1.19 \\
(0.41)\end{array}$ & $\begin{array}{l}-1.26 \\
(1.82)\end{array}$ & $\begin{array}{c}1.1 \\
(1.37)\end{array}$ & $\begin{array}{c}1.74 \\
(2.11)\end{array}$ & $\begin{array}{c}0.22 \\
(1.70)\end{array}$ & $\begin{array}{c}0.8 \\
(0.86)\end{array}$ & $\begin{array}{c}-2.5 \\
(1.42)\end{array}$ & $\begin{array}{l}-3.48 \\
(0.96)\end{array}$ & $\begin{array}{c}1.07 \\
(1.30)\end{array}$ & $\begin{array}{c}2.31 \\
(2.47)\end{array}$ \\
\hline 8. Recreation & $\begin{array}{c}1.6 \\
(0.24)\end{array}$ & $\begin{array}{l}-1.01 \\
(1.04)\end{array}$ & $\begin{array}{c}1.42 \\
(0.80)\end{array}$ & $\begin{array}{l}-2.05 \\
(1.19)\end{array}$ & $\begin{array}{c}1.64 \\
(0.97)\end{array}$ & $\begin{array}{c}0.06 \\
(0.51)\end{array}$ & $\begin{array}{c}0.32 \\
(0.82)\end{array}$ & $\begin{array}{c}1.38 \\
(0.60)\end{array}$ & $\begin{array}{l}-5.56 \\
(0.77)\end{array}$ & $\begin{array}{c}3.81 \\
(1.46)\end{array}$ \\
\hline 9. Miscellaneous & $\begin{array}{c}4.71 \\
(0.62)\end{array}$ & $\begin{array}{l}10.56 \\
(2.60)\end{array}$ & $\begin{array}{l}-1.46 \\
(2.06)\end{array}$ & $\begin{array}{c}0.63 \\
(2.97)\end{array}$ & $\begin{array}{c}2.29 \\
(2.39)\end{array}$ & $\begin{array}{c}1.51 \\
(1.28)\end{array}$ & $\begin{array}{l}-1.39 \\
(2.07)\end{array}$ & $\begin{array}{c}-0.69 \\
(1.47)\end{array}$ & $\begin{array}{c}2.67 \\
(1.91)\end{array}$ & $\begin{array}{r}-14.12 \\
(3.67)\end{array}$ \\
\hline \multicolumn{11}{|c|}{ B. Symmetry-constrained } \\
\hline 1. Food & $\begin{array}{l}-12.02 \\
(0.83)\end{array}$ & $\begin{array}{c}-11.86 \\
(3.76)\end{array}$ & $\begin{array}{c}2.8 \\
(0.95)\end{array}$ & $\begin{array}{c}3.83 \\
(2.19)\end{array}$ & $\begin{array}{c}0.02 \\
(0.72)\end{array}$ & $\begin{array}{c}-1 \\
(1.04)\end{array}$ & $\begin{array}{c}1.38 \\
(1.44)\end{array}$ & $\begin{array}{l}-1.28 \\
(1.30)\end{array}$ & $\begin{array}{l}-1.56 \\
(0.90)\end{array}$ & $\begin{array}{c}7.67 \\
(2.38)\end{array}$ \\
\hline 2. Clothing & $\begin{array}{l}-0.35 \\
(0.23)\end{array}$ & & $\begin{array}{l}-3.27 \\
(0.71)\end{array}$ & $\begin{array}{c}0.57 \\
(0.96)\end{array}$ & $\begin{array}{c}0.18 \\
(0.46)\end{array}$ & $\begin{array}{l}-1.26 \\
(0.41)\end{array}$ & $\begin{array}{c}0.85 \\
(0.63)\end{array}$ & $\begin{array}{l}-0.55 \\
(0.50)\end{array}$ & $\begin{array}{c}0.59 \\
(0.49)\end{array}$ & $\begin{array}{c}0.08 \\
(1.12)\end{array}$ \\
\hline 3. Housing & $\begin{array}{c}2.84 \\
(0.55)\end{array}$ & & & $\begin{array}{l}-12.5 \\
(2.50)\end{array}$ & $\begin{array}{c}1.4 \\
(0.78)\end{array}$ & $\begin{array}{c}1.67 \\
(0.84)\end{array}$ & $\begin{array}{c}0.33 \\
(1.21)\end{array}$ & $\begin{array}{c}3.84 \\
(1.03)\end{array}$ & $\begin{array}{c}-0.2 \\
(0.93)\end{array}$ & $\begin{array}{c}1.06 \\
(2.13)\end{array}$ \\
\hline 4. Furnishings & $\begin{array}{c}0.3 \\
(0.16)\end{array}$ & & & & $\begin{array}{c}-4.8 \\
(0.67)\end{array}$ & $\begin{array}{c}1.54 \\
(0.34)\end{array}$ & $\begin{array}{c}0.63 \\
(0.54)\end{array}$ & $\begin{array}{l}-0.66 \\
(0.37)\end{array}$ & $\begin{array}{c}0.27 \\
(0.46)\end{array}$ & $\begin{array}{c}1.41 \\
(0.93)\end{array}$ \\
\hline 5. Health & $\begin{array}{c}1.84 \\
(0.26)\end{array}$ & & & & & $\begin{array}{l}-7.59 \\
(0.58)\end{array}$ & $\begin{array}{c}1.83 \\
(0.53)\end{array}$ & $\begin{array}{c}0.9 \\
(0.53)\end{array}$ & $\begin{array}{c}1.13 \\
(0.40)\end{array}$ & $\begin{array}{c}2.76 \\
(0.98)\end{array}$ \\
\hline 6. Education & $\begin{array}{c}0.39 \\
(0.34)\end{array}$ & & & & & & $\begin{array}{l}-7.51 \\
(1.16)\end{array}$ & $\begin{array}{l}-0.45 \\
(0.68)\end{array}$ & $\begin{array}{c}1.68 \\
(0.63)\end{array}$ & $\begin{array}{c}1.27 \\
(1.41)\end{array}$ \\
\hline 7. Restaurants & $\begin{array}{c}1.17 \\
(0.37)\end{array}$ & & & & & & & $\begin{array}{l}-3.49 \\
(0.88)\end{array}$ & $\begin{array}{c}1.5 \\
(0.49)\end{array}$ & $\begin{array}{c}0.19 \\
(1.21)\end{array}$ \\
\hline 8. Recreation & $\begin{array}{c}1.63 \\
(0.23)\end{array}$ & & & & & & & & $\begin{array}{l}-6.17 \\
(0.85)\end{array}$ & $\begin{array}{c}2.76 \\
(1.46)\end{array}$ \\
\hline 9. Miscellaneous & $\begin{array}{c}4.19 \\
(0.60)\end{array}$ & & & & & & & & & $\begin{array}{r}-17.21 \\
(3.33)\end{array}$ \\
\hline \multicolumn{11}{|c|}{ C. Preference independence } \\
\hline 1. Food & $\begin{array}{l}-12.14 \\
(0.53)\end{array}$ & $\begin{array}{l}-11.81 \\
(0.66)\end{array}$ & $\begin{array}{c}0 . \overline{49} \\
(0.04)\end{array}$ & $\begin{array}{c}2.70 \\
(0.16)\end{array}$ & $\begin{array}{c}0.60 \\
(0.04)\end{array}$ & $\begin{array}{c}1.43 \\
(0.08)\end{array}$ & $\begin{array}{c}1.02 \\
(0.06)\end{array}$ & $\begin{array}{c}0.95 \\
(0.07)\end{array}$ & $\begin{array}{c}1.01 \\
(0.06)\end{array}$ & $\begin{array}{c}3.62 \\
(0.21)\end{array}$ \\
\hline 2. Clothing & $\begin{array}{l}-0.57 \\
(0.17)\end{array}$ & & $\begin{array}{l}-2.79 \\
(0.20)\end{array}$ & $\begin{array}{c}0.55 \\
(0.04)\end{array}$ & $\begin{array}{c}0.12 \\
(0.01)\end{array}$ & $\begin{array}{c}0.29 \\
(0.02)\end{array}$ & $\begin{array}{c}0.21 \\
(0.02)\end{array}$ & $\begin{array}{c}0.19 \\
(0.02)\end{array}$ & $\begin{array}{c}0.21 \\
(0.02)\end{array}$ & $\begin{array}{c}0.74 \\
(0.05)\end{array}$ \\
\hline 3. Housing & $\begin{array}{c}2.97 \\
(0.42)\end{array}$ & & & $\begin{array}{l}-12.95 \\
(0.71)\end{array}$ & $\begin{array}{c}0.67 \\
(0.04)\end{array}$ & $\begin{array}{c}1.61 \\
(0.08)\end{array}$ & $\begin{array}{c}1.14 \\
(0.07)\end{array}$ & $\begin{array}{c}1.07 \\
(0.08)\end{array}$ & $\begin{array}{c}1.14 \\
(0.07)\end{array}$ & $\begin{array}{c}4.07 \\
(0.24)\end{array}$ \\
\hline 4. Furnishings & $\begin{array}{c}0.21 \\
(0.11)\end{array}$ & & & & $\begin{array}{c}-3.40 \\
(0.18)\end{array}$ & $\begin{array}{c}0.36 \\
(0.02)\end{array}$ & $\begin{array}{c}0.25 \\
(0.02)\end{array}$ & $\begin{array}{c}0.24 \\
(0.02)\end{array}$ & $\begin{array}{c}0.25 \\
(0.02)\end{array}$ & $\begin{array}{c}0.90 \\
(0.05)\end{array}$ \\
\hline 5. Health & $\begin{array}{c}2.08 \\
(0.19)\end{array}$ & & & & & $\begin{array}{l}-7.64 \\
(0.36)\end{array}$ & $\begin{array}{c}0.61 \\
(0.04)\end{array}$ & $\begin{array}{c}0.57 \\
(0.04)\end{array}$ & $\begin{array}{c}0.60 \\
(0.03)\end{array}$ & $\begin{array}{c}2.16 \\
(0.11)\end{array}$ \\
\hline 6. Education & $\begin{array}{c}0.16 \\
(0.23)\end{array}$ & & & & & & $\begin{array}{l}-5.60 \\
(0.34)\end{array}$ & $\begin{array}{c}0.40 \\
(0.03)\end{array}$ & $\begin{array}{c}0.43 \\
(0.03)\end{array}$ & $\begin{array}{c}1.54 \\
(0.10)\end{array}$ \\
\hline 7. Restaurants & $\begin{array}{c}1.70 \\
(0.31)\end{array}$ & & & & & & & $\begin{array}{l}-5.27 \\
(0.38)\end{array}$ & $\begin{array}{c}0.40 \\
(0.03)\end{array}$ & $\begin{array}{c}1.44 \\
(0.11)\end{array}$ \\
\hline 8. Recreation & $\begin{array}{c}2.11 \\
(0.17)\end{array}$ & & & & & & & & $\begin{array}{l}-5.57 \\
(0.32)\end{array}$ & $\begin{array}{c}1.53 \\
(0.09)\end{array}$ \\
\hline 9. Miscellaneous & $\begin{array}{c}3.47 \\
(0.41)\end{array}$ & & & & & & & & & $\begin{array}{r}-16.00 \\
(0.86)\end{array}$ \\
\hline & & & & Inc & me flex & ity $\phi=$ & $-0.84(0$ & 04) & & \\
\hline & & & & o price & ffects & & & & & \\
\hline Income coefficient & & $\begin{array}{c}\beta_{1} \\
-10.56 \\
(0.57) \\
\end{array}$ & $\begin{array}{c}\beta_{2} \\
-0.72 \\
(0.17) \\
\end{array}$ & $\begin{array}{c}\beta_{3} \\
2.88 \\
(0.46) \\
\end{array}$ & $\begin{array}{c}\beta_{4} \\
0.41 \\
(0.13) \\
\end{array}$ & $\begin{array}{c}\beta_{5} \\
3.18 \\
(0.28) \\
\end{array}$ & $\begin{array}{c}\beta_{6} \\
-0.19 \\
(0.25) \\
\end{array}$ & $\begin{array}{c}\beta_{7} \\
0.66 \\
(0.28) \\
\end{array}$ & $\begin{array}{c}\beta_{8} \\
1.53 \\
(0.19) \\
\end{array}$ & $\begin{array}{c}\beta_{9} \\
2.82 \\
(0.42) \\
\end{array}$ \\
\hline
\end{tabular}

Note: This table presents three sets of estimates of model (5.5). Except for the income flexibility, all entries are multiplied by 100. Standard errors (SEs) are in parentheses. For panels A, B, D, the SEs are from 1,000 bootstrap replications. For panel C, SEs are from nonlinear SURE. Own-price coefficients are emboldened. Intercepts included in each equation but not reported. 
Table 5. Hypothesis Tests

\begin{tabular}{|c|c|c|c|c|}
\hline & \multicolumn{4}{|c|}{ Null Models } \\
\hline & \multicolumn{3}{|l|}{ Least restrictive $\leftarrow$} & \multirow{2}{*}{$\begin{array}{c}\rightarrow \text { Most restrictive } \\
\text { No-price effects } \\
\pi_{i j}=0, \forall i, j\end{array}$} \\
\hline & $\begin{array}{c}\text { Homogeneity } \\
\sum_{j=1}^{9} \pi_{i j}=0 ; \pi_{i j} \neq \\
\pi_{j i}, \forall i \neq j\end{array}$ & $\begin{array}{c}\text { Symmetry } \\
\sum_{j=1}^{9} \pi_{i j}=0 ; \pi_{i j}= \\
\pi_{j i}, \forall i \neq j\end{array}$ & $\begin{array}{l}\text { Preference independence } \\
\qquad(\mathrm{PI}) \\
\pi_{i j}=\phi \theta_{i}\left(\delta_{i j}-\theta_{j}\right), \forall i, j\end{array}$ & \\
\hline \multicolumn{5}{|c|}{ A. Degrees of freedom and likelihood } \\
\hline $\begin{array}{l}\text { No. of free price } \\
\text { parameters }\end{array}$ & 64 & 36 & 1 & 0 \\
\hline Log-likelihood value & 2955.3 & 2930.2 & 2880.5 & 2736.7 \\
\hline \multicolumn{5}{|c|}{ B. Likelihood-ratio statistic } \\
\hline \multicolumn{5}{|c|}{ ( $5 \%$ critical value; $1 \%$ critical value; d.f) } \\
\hline \multicolumn{5}{|l|}{ Alternative Models } \\
\hline Homogeneity & - & $\begin{array}{c}50.3 \\
(41.3 ; 48.3 ; 28)\end{array}$ & $\begin{array}{c}149.7 \\
(82.5 ; 92.0 ; 63)\end{array}$ & $\begin{array}{c}437.3 \\
(83.6 ; 93.2 ; 64)\end{array}$ \\
\hline Symmetry & - & 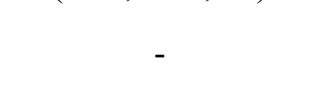 & $\begin{array}{c}99.4 \\
(49.8 ; 57.3 ; 35)\end{array}$ & $\begin{array}{c}387 \\
(50.9 ; 58.6 ; 36)\end{array}$ \\
\hline PI & - & - & (a & $\begin{array}{c}287.6 \\
(3.84 ; 6.63 ; 1)\end{array}$ \\
\hline
\end{tabular}

Note: The likelihood-ratio test statistic is $-2 \times \log \left(L_{r} / L_{u}\right)$, where $L_{r}$ and $L_{u}$ denote the likelihood values corresponding to the restricted (null) and unrestricted (alternative) models, respectively. Under the null, this follows a $\chi^{2}$ distribution with degrees of freedom equal to the difference in the number of free parameters. The number of free parameters equals the difference in the number of free price parameters (as the number of intercepts and income coefficients is the same across models).

Table 6. Income and Own-Price Elasticities

\begin{tabular}{|c|c|c|c|c|c|}
\hline & \multicolumn{4}{|c|}{ Income quartile } & \multirow[b]{2}{*}{ All countries } \\
\hline $\begin{array}{l}\text { Commodity } \\
\text { (1) }\end{array}$ & $\begin{array}{c}\leftarrow \text { RICHER } \\
\text { First } \\
\text { (2) }\end{array}$ & $\begin{array}{l}\text { Second } \\
\text { (3) }\end{array}$ & $\begin{array}{l}\text { Third } \\
\text { (4) }\end{array}$ & $\begin{array}{c}\text { POORER } \rightarrow \\
\text { Fourth } \\
(5)\end{array}$ & \\
\hline \multicolumn{6}{|c|}{ A. Income elasticities } \\
\hline 1. Food & -0.28 & 0.42 & 0.60 & 0.73 & 0.37 \\
\hline 2. Clothing & 0.89 & 0.91 & 0.92 & 0.92 & 0.91 \\
\hline 3. Housing & 1.14 & 1.16 & 1.19 & 1.25 & 1.19 \\
\hline 4. Furnishings & 1.06 & 1.06 & 1.07 & 1.07 & 1.07 \\
\hline 5. Health & 1.17 & 1.21 & 1.27 & 1.46 & 1.28 \\
\hline 6. Education & 1.05 & 1.05 & 1.05 & 1.05 & 1.05 \\
\hline 7. Restaurants & 1.20 & 1.26 & 1.33 & 1.55 & 1.34 \\
\hline 8. Recreation & 1.23 & 1.32 & 1.44 & 1.65 & 1.41 \\
\hline 9. Miscellaneous & 1.15 & 1.17 & 1.19 & 1.24 & 1.19 \\
\hline \multicolumn{6}{|c|}{ B. Own-price elasticities } \\
\hline 1. Food & -1.26 & -0.57 & -0.39 & -0.27 & -0.62 \\
\hline 2. Clothing & -0.99 & -0.82 & -0.78 & -0.76 & -0.84 \\
\hline 3. Housing & -0.63 & -0.70 & -0.83 & -1.10 & -0.81 \\
\hline 4. Furnishings & -1.00 & -1.00 & -1.05 & -1.16 & -1.05 \\
\hline 5. Health & -0.71 & -0.88 & -1.10 & -1.89 & -1.15 \\
\hline 6. Education & -0.95 & -0.97 & -1.01 & -1.04 & -1.00 \\
\hline 7. Restaurants & -0.59 & -0.79 & -0.97 & -1.65 & -1.00 \\
\hline 8. Recreation & -0.87 & -1.23 & -1.66 & -2.44 & -1.55 \\
\hline 9. Miscellaneous & -0.61 & -0.68 & -0.78 & -0.98 & -0.76 \\
\hline
\end{tabular}

Notes:

1. The income elasticity of good $i$ in country $c$ is $\theta_{i c} / \widehat{w}_{i c}=1+\beta_{i} / \widehat{w}_{i c}$ where $\beta_{i}$ is the estimated income coefficient from panel $\mathrm{B}$ of Table 4 and $\widehat{w}_{i c}$ is the predicted budget share.

2. The own-price elasticity is $\pi_{i i} / \widehat{w}_{i c}$, where $\pi_{i i}$ is the estimated own-Slutsky coefficient from panel B of Table 4 .

3. Individual-country elasticities are given in Tables A4.1 and A4.2 of Appendix A4.

4. All entries are cross-country averages. 
Table 7. Predictions of Consumption Patterns (Information inaccuracies)

\begin{tabular}{|c|c|c|c|c|c|}
\hline \multirow[b]{2}{*}{$\begin{array}{l}\text { Prediction } \\
\text { (1) }\end{array}$} & \multicolumn{4}{|c|}{ Income quartile } & \multirow[b]{2}{*}{$\begin{array}{l}\text { All countries } \\
(6)\end{array}$} \\
\hline & $\begin{array}{c}\leftarrow \text { RICHER } \\
\text { First } \\
(2)\end{array}$ & $\begin{array}{l}\text { Second } \\
(3)\end{array}$ & $\begin{array}{l}\text { Third } \\
(4)\end{array}$ & $\begin{array}{c}\text { POORER } \rightarrow \\
\text { Fourth } \\
(5) \\
\end{array}$ & \\
\hline \multicolumn{6}{|c|}{ A. All commodities } \\
\hline $\begin{array}{l}\text { Unconditional } \\
\qquad \widehat{w}_{i c}=\bar{w}_{i}\end{array}$ & 11.75 & 6.91 & 6.91 & 16.63 & 10.55 \\
\hline $\begin{array}{l}\text { Conditional on income } \\
\qquad \widehat{w}_{i c}=\hat{\alpha}_{i}+\hat{\beta}_{i} \log Q_{c}\end{array}$ & $6.72(-43)$ & $8.15(18)$ & $8.76(27)$ & $9.85(-41)$ & $8.37(-21)$ \\
\hline $\begin{array}{l}\text { Conditional on income and prices } \\
\widehat{w}_{i c}=w_{i c}-\hat{\varepsilon}_{i c}\end{array}$ & $4.49(-61)$ & $5.92(-14)$ & $7.61(10)$ & $10.15(-39)$ & $7.04(-33)$ \\
\hline \multicolumn{6}{|c|}{ B. Food } \\
\hline $\begin{array}{l}\text { Unconditional } \\
\qquad \widehat{w}_{i c}=\bar{w}_{i}\end{array}$ & 7.57 & 2.53 & 1.84 & 10.82 & 5.69 \\
\hline $\begin{array}{l}\text { Conditional on income } \\
\qquad \widehat{w}_{i c}=\hat{\alpha}_{i}+\hat{\beta}_{i} \log Q_{c}\end{array}$ & $1.27(-83)$ & $1.29(-49)$ & $1.89(3)$ & $2.57(-76)$ & $1.76(-69)$ \\
\hline $\begin{array}{l}\text { Conditional on income and prices } \\
\widehat{w}_{i c}=w_{i c}-\hat{\varepsilon}_{i c}\end{array}$ & $0.78(-89)$ & $0.87(-66)$ & $1.93(5)$ & $2.62(-76)$ & $1.55(-73)$ \\
\hline
\end{tabular}

Notes:

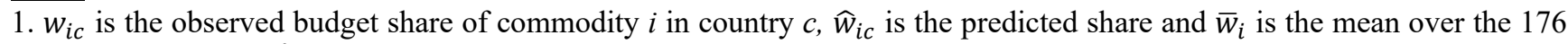
countries; $\hat{\alpha}_{i}$ and $\hat{\beta}_{i}$ are estimated coefficients from panel D of Table 4; and $\hat{\varepsilon}_{i c}$ is the residual associated with the estimates of panel B of Table 4. See Appendix A4 for details.

2. Panel A contains the information inaccuracies for the 9 commodities, $100 \times\left[\Sigma_{i=1}^{9} w_{i c} \log \left(w_{i c} / \widehat{w}_{i c}\right)\right]$, averaged over countries.

3. Panel $\mathrm{B}$ contains the inaccuracies for $i=$ food and its complement, $100 \times\left\{w_{i c} \log \left(w_{i c} / \widehat{w}_{i c}\right)+\left(1-w_{i c}\right) \log [(1-\right.$ $\left.\left.\left.w_{i c}\right) /\left(1-\widehat{w}_{i c}\right)\right]\right\}$, averaged over countries.

4. Entries in parentheses are percentage changes from unconditional information inaccuracy. 
Table 8. Income, Quality of Consumption and its Price

\begin{tabular}{|c|c|c|c|c|c|c|c|}
\hline \multirow{2}{*}{$\begin{array}{c}\text { Country } \\
\text { (1) }\end{array}$} & \multirow{2}{*}{$\begin{array}{c}\text { Income } \\
(\mathrm{US}=100) \\
(2)\end{array}$} & \multicolumn{2}{|c|}{$\begin{array}{l}\text { Quality indexes } \\
\qquad \times 100)\end{array}$} & \multirow{2}{*}{$\begin{array}{l}\text { Country } \\
(5)\end{array}$} & \multirow{2}{*}{$\begin{array}{c}\text { Income } \\
(\mathrm{US}=100) \\
(6)\end{array}$} & \multicolumn{2}{|c|}{$\begin{array}{l}\text { Quality indexes } \\
(\times 100)\end{array}$} \\
\hline & & $\begin{array}{l}\text { Quantity } \\
\text { (3) }\end{array}$ & $\begin{array}{l}\text { Price } \\
(4)\end{array}$ & & & $\begin{array}{l}\text { Quantity } \\
\text { (7) }\end{array}$ & $\begin{array}{c}\text { Price } \\
(8)\end{array}$ \\
\hline \multicolumn{4}{|c|}{ A. First quartile } & \multicolumn{4}{|c|}{ B. Second quartile } \\
\hline 1. Bermuda & 107.0 & 9.4 & 4.2 & 45. Bahamas, The & 41.0 & 8.2 & 4.3 \\
\hline 2. Luxembourg & 104.9 & 5.6 & 6.5 & 46. Panama & 40.8 & 7.8 & -1.5 \\
\hline 3. United States & 100.0 & 14.3 & 6.0 & 47. Slovak Republic & 40.7 & 4.7 & 1.8 \\
\hline 4. Hong Kong SAR & 95.6 & 14.6 & 0.1 & 48. Latvia & 40.0 & 3.5 & 1.2 \\
\hline 5. Switzerland & 89.6 & 10.9 & 4.3 & 49. Bahrain & 39.6 & 10.8 & -0.2 \\
\hline 6. Iceland & 83.0 & 9.4 & 3.9 & 50. Curaçao & 39.3 & 11.2 & 2.6 \\
\hline 7. Australia & 82.9 & 13.6 & 2.0 & 51. Mauritius & 39.3 & 2.1 & -2.3 \\
\hline 8. Austria & 82.1 & 12.1 & 3.4 & 52. Anguilla & 38.4 & 7.6 & 0.6 \\
\hline 9. Norway & 82.0 & 13.2 & 2.0 & 53. Trinidad and Tobago & 37.5 & 9.7 & -0.3 \\
\hline 10. Denmark & 80.2 & 11.1 & 4.6 & 54. Kuwait & 37.3 & 8.6 & 1.6 \\
\hline 11. United Kingdom & 76.5 & 13.0 & 4.6 & 55. Romania & 37.3 & -0.3 & 0.7 \\
\hline 12. Cayman Islands & 76.5 & 14.4 & 3.9 & 56. Montserrat & 37.2 & 11.3 & -4.9 \\
\hline 13. Germany & 76.5 & 10.3 & 4.8 & 57. Hungary & 37.0 & 4.4 & 1.5 \\
\hline 14. Finland & 76.0 & 10.3 & 3.6 & 58. Argentina & 36.7 & 3.6 & 0.3 \\
\hline 15. Singapore & 74.2 & 19.7 & 0.2 & 59. Montenegro & 36.7 & -2.0 & 0.4 \\
\hline 16. Netherlands & 71.0 & 9.6 & 5.9 & 60. Turkey & 36.4 & 8.0 & -2.0 \\
\hline 17. Sweden & 70.8 & 10.1 & 4.9 & 61. Malaysia & 35.4 & 5.7 & -0.9 \\
\hline 18. France & 70.4 & 9.7 & 3.5 & 62. St. Kitts and Nevis & 34.2 & 6.2 & -0.6 \\
\hline 19. Canada & 68.4 & 11.6 & 4.1 & 63. Russian Federation & 33.0 & -1.1 & 0.3 \\
\hline 20. Belgium & 68.0 & 7.3 & 4.9 & 64. Uruguay & 32.7 & 3.9 & 0.9 \\
\hline 21. Taiwan, China & 67.5 & 13.5 & -2.7 & 65. Chile & 32.7 & 5.1 & 1.9 \\
\hline 22. Cyprus & 64.4 & 6.4 & 2.4 & 66. Costa Rica & 32.5 & 8.4 & -0.7 \\
\hline 23. New Zealand & 61.0 & 8.1 & 1.0 & 67. Barbados & 31.4 & 10.0 & 0.7 \\
\hline 24. Ireland & 60.3 & 11.6 & 2.9 & 68. Bulgaria & 31.0 & 5.8 & -0.3 \\
\hline 25. Italy & 59.7 & 5.6 & 4.2 & 69. Brunei Darussalam & 30.6 & 9.1 & -0.2 \\
\hline 26. Malta & 59.5 & 9.6 & 1.5 & 70. British Virgin Islands & 30.2 & -2.9 & 3.2 \\
\hline 27. UAE & 59.2 & 11.5 & 1.6 & 71. Oman & 30.0 & 2.9 & 2.1 \\
\hline 28. Japan & 57.8 & 10.4 & 1.4 & 72. Kazakhstan & 28.2 & -0.7 & 1.0 \\
\hline 29. Qatar & 56.4 & 15.2 & 3.7 & 73. Grenada & 27.6 & 3.7 & -1.7 \\
\hline 30. Israel & 56.3 & 8.0 & 2.4 & 74. Mexico & 27.2 & 0.4 & 2.0 \\
\hline 31. Spain & 55.0 & 6.1 & 5.6 & 75. Antigua and Barbuda & 25.7 & 6.2 & 0.3 \\
\hline 32. Korea, Rep. & 50.0 & 17.6 & -3.4 & 76. Serbia & 24.0 & 0.1 & 0.1 \\
\hline 33. Portugal & 49.9 & 4.8 & 3.4 & 77. Belarus & 23.8 & -3.0 & -0.3 \\
\hline 34. Lithuania & 48.8 & 1.2 & 1.3 & 78. Dominican Republic & 23.5 & 0.8 & -1.3 \\
\hline 35. Sint Maarten & 48.3 & 11.4 & 3.0 & 79. Bosn. \& Herz. & 22.5 & -4.0 & 0.8 \\
\hline 36. Slovenia & 47.5 & 5.2 & 4.2 & 80. Turks \& Caicos Is. & 22.1 & 6.1 & 2.4 \\
\hline 37. Greece & 47.3 & 4.4 & 2.6 & 81. Egypt, Arab Rep. & 21.8 & -2.5 & -5.2 \\
\hline 38. Czech Republic & 47.0 & 3.9 & 2.5 & 82. Jamaica & 21.7 & 5.0 & -3.5 \\
\hline 39. Aruba & 46.8 & 13.5 & 0.7 & 83. Albania & 21.1 & -6.6 & -0.3 \\
\hline 40. Saudi Arabia & 45.3 & 6.1 & -0.2 & 84. Brazil & 20.8 & 3.1 & 4.1 \\
\hline 41. Croatia & 44.2 & 4.0 & 0.7 & 85. Thailand & 20.8 & 1.7 & -0.5 \\
\hline 42. Estonia & 44.2 & 2.2 & 1.9 & 86. Colombia & 20.5 & 5.0 & 0.8 \\
\hline 43. Poland & 44.1 & 5.0 & 1.4 & 87. Equatorial Guinea & 20.4 & -2.1 & -3.0 \\
\hline 44. Seychelles & 42.8 & 10.0 & -4.7 & 88. North Macedonia & 20.2 & -4.2 & 1.0 \\
\hline Mean & 65.9 & 9.7 & 2.6 & Mean & 30.9 & 3.7 & 0.2 \\
\hline Median & 62.7 & 10.0 & 2.9 & Median & 31.9 & 4.1 & 0.3 \\
\hline S.D & 17.3 & 4.0 & 2.4 & S.D & 7.0 & 4.6 & 2.0 \\
\hline
\end{tabular}


Table 8. Income, Quality of Consumption and its Price (cont'd)

\begin{tabular}{|c|c|c|c|c|c|c|c|}
\hline \multirow{2}{*}{$\begin{array}{c}\text { Country } \\
(1)\end{array}$} & \multirow{2}{*}{$\begin{array}{c}\text { Income } \\
(\mathrm{US}=100) \\
(2)\end{array}$} & \multicolumn{2}{|c|}{$\begin{array}{l}\text { Quality indexes } \\
\qquad(\times 100)\end{array}$} & \multirow{2}{*}{$\begin{array}{c}\text { Country } \\
(5)\end{array}$} & \multirow{2}{*}{$\begin{array}{c}\text { Income } \\
(\mathrm{US}=100) \\
(6)\end{array}$} & \multicolumn{2}{|c|}{$\begin{array}{l}\text { Quality indexes } \\
(\times 100)\end{array}$} \\
\hline & & $\begin{array}{l}\text { Quantity } \\
\text { (3) }\end{array}$ & $\begin{array}{c}\text { Price } \\
(4)\end{array}$ & & & $\begin{array}{l}\text { Quantity } \\
(7)\end{array}$ & $\begin{array}{c}\text { Price } \\
(8)\end{array}$ \\
\hline \multicolumn{4}{|c|}{ C. Third quartile } & \multicolumn{4}{|c|}{ D. Fourth quartile } \\
\hline 89. Tunisia & 19.9 & 1.5 & 0.0 & 133. India & 7.7 & -2.4 & -1.1 \\
\hline 90. Sri Lanka & 19.8 & 5.4 & -5.2 & 134. Lao PDR & 7.5 & -9.2 & -2.0 \\
\hline 91. Dominica & 19.0 & 6.6 & -0.4 & 135. Uzbekistan & 7.4 & -7.8 & -3.6 \\
\hline 92. Azerbaijan & 18.4 & -5.4 & 0.0 & 136. Angola & 7.4 & -6.6 & -3.2 \\
\hline 93. St. Vincent \& the Gr. & 18.4 & 3.2 & -1.2 & 137. Nigeria & 7.3 & -13.7 & -4.3 \\
\hline 94. South Africa & 18.4 & 2.0 & 0.4 & 138. Lesotho & 5.8 & -8.4 & 1.1 \\
\hline 95. Namibia & 18.2 & -0.8 & 2.2 & 139. Cambodia & 5.8 & -9.8 & -0.9 \\
\hline 96. Peru & 17.4 & 2.4 & 1.1 & 140. Sudan & 5.6 & -10.7 & -3.8 \\
\hline 97. Georgia & 17.4 & 0.8 & -0.7 & 141. Bangladesh & 5.4 & -13.7 & -2.0 \\
\hline 98. Fiji & 17.2 & -9.3 & -2.9 & 142. São Tomé \& Pr. & 5.3 & -16.1 & -1.7 \\
\hline 99. Maldives & 17.1 & 5.8 & 2.1 & 143. Ghana & 5.2 & 1.7 & -5.5 \\
\hline 100. Ukraine & 17.0 & -5.1 & -3.5 & 144. Comoros & 5.1 & -10.8 & -4.3 \\
\hline 101. Iran, Islamic Rep. & 16.9 & 4.6 & -4.9 & 145. Senegal & 4.9 & -8.1 & -3.0 \\
\hline 102. Armenia & 16.6 & -9.7 & -1.4 & 146. Cameroon & 4.9 & -6.4 & 0.3 \\
\hline 103. Paraguay & 16.3 & -3.0 & 2.4 & 147. Côte d'Ivoire & 4.7 & -10.8 & -0.9 \\
\hline 104. Suriname & 15.9 & -2.5 & -3.9 & 148. Congo, Rep. & 4.7 & -2.8 & -3.9 \\
\hline 105. Botswana & 15.3 & -20.9 & -0.9 & 149. Myanmar & 4.2 & -13.0 & -2.5 \\
\hline 106. Ecuador & 14.9 & 1.7 & 0.2 & 150. Zimbabwe & 4.1 & -8.6 & -0.5 \\
\hline 107. China & 14.8 & 7.2 & 0.1 & 151. Nepal & 4.1 & -14.3 & -3.8 \\
\hline 108. Moldova & 14.5 & -4.1 & 0.7 & 152. Tanzania & 4.0 & -13.8 & 0.4 \\
\hline 109. Jordan & 14.2 & 1.5 & -1.1 & 153. Tajikistan & 4.0 & -5.8 & -3.4 \\
\hline 110. Eswatini & 14.0 & -7.1 & -0.4 & 154. Gambia, The & 3.7 & -10.9 & -4.9 \\
\hline 111. El Salvador & 13.9 & -3.0 & 1.3 & 155. Mauritania & 3.7 & -15.9 & -3.5 \\
\hline 112. Indonesia & 13.3 & -2.6 & -2.5 & 156. Guinea & 3.6 & -16.2 & -5.7 \\
\hline 113. Algeria & 13.3 & -3.2 & -4.5 & 157. Haiti & 3.5 & -17.2 & -1.7 \\
\hline 114. Bhutan & 12.2 & -4.2 & -1.8 & 158. Benin & 3.5 & -9.1 & -1.4 \\
\hline 115. Mongolia & 11.8 & -5.9 & 0.3 & 159. Zambia & 3.2 & -7.8 & 0.3 \\
\hline 116. Cabo Verde & 11.7 & -3.7 & 0.8 & 160. Uganda & 3.1 & -6.8 & -0.7 \\
\hline 117. Bolivia & 11.7 & -8.6 & 2.9 & 161. Mali & 3.1 & -15.8 & 0.9 \\
\hline 118. Philippines & 11.6 & -7.1 & -0.2 & 162. Rwanda & 3.1 & -8.6 & 1.2 \\
\hline 119. Belize & 11.0 & 2.3 & 1.1 & 163. Sierra Leone & 3.0 & -10.1 & -2.2 \\
\hline 120. W. Bank \& Gaza & 10.7 & -1.2 & -1.6 & 164. Guinea-Bissau & 2.6 & -23.8 & -3.1 \\
\hline 121. Guyana & 10.7 & -4.0 & -0.8 & 165. Togo & 2.2 & -7.5 & -3.3 \\
\hline 122. Iraq & 10.5 & -3.8 & 0.3 & 166. Ethiopia & 2.2 & -10.0 & -4.6 \\
\hline 123. Gabons & 10.2 & -5.4 & -1.8 & 167. Madagascar & 2.1 & -18.2 & -1.4 \\
\hline 124. Vietnam & 10.0 & -0.2 & -1.3 & 168. Chad & 2.1 & -16.7 & -0.6 \\
\hline 125. Morocco & 9.9 & -4.1 & 0.2 & 169. Burkina Faso & 2.0 & -13.4 & -0.9 \\
\hline 126. Nicaragua & 9.2 & -0.4 & -0.6 & 170. Liberia & 2.0 & 0.0 & -7.9 \\
\hline 127. St. Lucia & 9.1 & 6.3 & 1.6 & 171. Mozambique & 1.7 & -18.0 & 0.4 \\
\hline 128. Honduras & 9.0 & -4.7 & 1.5 & 172. Malawi & 1.7 & -16.6 & 2.7 \\
\hline 129. Djibouti & 8.4 & -1.5 & 0.5 & 173. Congo, Dem. Rep. & 1.6 & -18.8 & -2.0 \\
\hline 130. Kenya & 8.1 & -5.6 & -1.1 & 174. Central Afri. Rep. & 1.4 & -18.6 & -2.1 \\
\hline 131. Pakistan & 8.1 & -2.3 & -1.7 & 175. Burundi & 1.3 & -12.0 & -3.3 \\
\hline 132. Kyrgyz Rep. & 7.8 & -9.2 & -1.9 & 176. Niger & 1.2 & -6.7 & -2.4 \\
\hline Mean & 13.7 & -2.2 & -0.6 & Mean & 3.9 & -11.1 & -2.2 \\
\hline Median & 13.9 & -2.8 & -0.4 & Median & 3.7 & -10.7 & -2.1 \\
\hline S.D & 3.6 & 5.3 & 1.9 & S.D & 1.8 & 5.3 & 2.1 \\
\hline
\end{tabular}

Notes:

1. Columns 3 and 7: The index of the quality of consumption for country $c$ is the weighted covariance between income elasticities $\eta_{i c}$ and quantity differences, $y_{\eta q, c}=\sum_{i=1}^{9} \widehat{w}_{i c}\left(\eta_{i c}-1\right)\left(\Delta \log q_{i c}-\Delta \log Q_{c}\right)$, where $\Delta \log q_{i c}=\log q_{i c}-\log q_{i}^{*}$ and $\Delta \log Q_{c}=$ $\sum_{i=1}^{9} \widehat{w}_{i c} \Delta \log q_{i c}$, with $\log q_{i}^{*}=(1 / 176) \sum_{d=1}^{176} \log q_{i d}$ the cross-country average; and $\widehat{w}_{i c}$ is the predicted budget share. As the average of the quality index over the 176 countries is zero, $y_{\eta q, c} \times 100$ is the percentage difference of quality in $c$ from the world average.

2. Columns 4 and 8: The index of the price of quality is $y_{\eta p, c}=\sum_{i=1}^{9} \widehat{w}_{i c}\left(\eta_{i c}-1\right)\left(\Delta \log p_{i c}-\Delta \log P_{c}\right)$, where $\Delta \log p_{i c}=\log p_{i c}-$ $\log p_{i}^{*}$ and $\Delta \log P_{c}=\sum_{i=1}^{9} \widehat{w}_{i c} \Delta \log p_{i c}$, with $\log p_{i}^{*}=(1 / 176) \sum_{d=1}^{176} \log p_{i d}$. 
Table 9. Determinants of the Quality of Consumption and its Price

(Coefficients and standard errors are $\times 100$ )

\begin{tabular}{|c|c|c|c|c|c|c|c|c|c|c|c|c|}
\hline \multirow[b]{2}{*}{$\begin{array}{l}\text { Determinants } \\
\text { (1) }\end{array}$} & \multicolumn{6}{|c|}{ Quality of Consumption } & \multicolumn{6}{|c|}{ Price of quality } \\
\hline & $\begin{array}{l}\text { Model } 1 \\
\text { (2) }\end{array}$ & $\begin{array}{c}2 \\
(3)\end{array}$ & $\begin{array}{c}3 \\
(4)\end{array}$ & $\begin{array}{c}4 \\
(5)\end{array}$ & $\begin{array}{c}5 \\
(6)\end{array}$ & $\begin{array}{c}6 \\
(7)\end{array}$ & $\begin{array}{l}\text { Model } 1 \\
\text { (8) }\end{array}$ & $\begin{array}{c}2 \\
(9)\end{array}$ & $\begin{array}{c}3 \\
(10)\end{array}$ & $\begin{array}{c}4 \\
(11)\end{array}$ & $\begin{array}{c}5 \\
(12)\end{array}$ & $\begin{array}{c}6 \\
(13)\end{array}$ \\
\hline \multicolumn{13}{|c|}{ A. All countries $(C=130)$} \\
\hline Income & $\begin{array}{c}6.46^{* * *} \\
(0.32)\end{array}$ & $\begin{array}{c}4.94 * * * \\
(0.50)\end{array}$ & $\begin{array}{c}5.07^{* * *} \\
(0.51)\end{array}$ & $\begin{array}{c}3.92 * * * \\
(0.76)\end{array}$ & $\begin{array}{c}3.49 * * * \\
(0.96)\end{array}$ & $\begin{array}{c}3.49 * * * \\
(0.97)\end{array}$ & $\begin{array}{c}1.54 * * * \\
(0.16)\end{array}$ & $\begin{array}{c}1.06^{* * *} \\
(0.26)\end{array}$ & $\begin{array}{c}1.14 * * * \\
(0.26)\end{array}$ & $\begin{array}{l}0.65^{*} \\
(0.39)\end{array}$ & $\begin{array}{c}0.09 \\
(0.49)\end{array}$ & $\begin{array}{c}0.15 \\
(0.49)\end{array}$ \\
\hline Happiness & & $\begin{array}{c}19.99 * * * \\
(5.20)\end{array}$ & $\begin{array}{c}20.51 * * * \\
(5.19)\end{array}$ & $\begin{array}{c}18.10^{* * *} \\
(5.27)\end{array}$ & $\begin{array}{c}17.92 * * * \\
(5.28)\end{array}$ & $\begin{array}{c}17.94 * * * \\
(5.46)\end{array}$ & & $\begin{array}{l}6.27 * * \\
(2.66)\end{array}$ & $\begin{array}{l}6.58^{* *} \\
(2.65)\end{array}$ & $\begin{array}{l}5.55^{* *} \\
(2.70)\end{array}$ & $\begin{array}{l}5.32 * * \\
(2.68)\end{array}$ & $\begin{array}{l}5.89 * * \\
(2.76)\end{array}$ \\
\hline Income inequality & & & $\begin{array}{c}7.03 \\
(5.07)\end{array}$ & $\begin{array}{c}11.64 * * \\
(5.51)\end{array}$ & $\begin{array}{c}11.87 * * \\
(5.52)\end{array}$ & $\begin{array}{c}11.88^{* * *} \\
(5.63)\end{array}$ & & & $\begin{array}{c}4.23 \\
(2.59)\end{array}$ & $\begin{array}{l}6.21 * * \\
(2.83)\end{array}$ & $\begin{array}{l}6.51^{* *} \\
(2.80)\end{array}$ & $\begin{array}{l}6.93 * * \\
(2.85)\end{array}$ \\
\hline Human capital & & & & $\begin{array}{c}12.32 * * \\
(6.12)\end{array}$ & $\begin{array}{l}10.90^{*} \\
(6.41)\end{array}$ & $\begin{array}{c}10.89^{*} \\
(6.51)\end{array}$ & & & & $\begin{array}{l}5.29^{*} \\
(3.14)\end{array}$ & $\begin{array}{l}3.46 \\
(3.25)\end{array}$ & $\begin{array}{l}3.03 \\
(3.29)\end{array}$ \\
\hline$\%$ pop. with internet & & & & & $\begin{array}{c}2.80 \\
(3.73)\end{array}$ & $\begin{array}{c}2.82 \\
(3.95)\end{array}$ & & & & & $\begin{array}{l}3.62 * \\
(1.89)\end{array}$ & $\begin{array}{l}4.16^{* * *} \\
(2.00)\end{array}$ \\
\hline Urbanisation & & & & & & $\begin{array}{l}-0.04 \\
(2.87)\end{array}$ & & & & & & $\begin{array}{l}-1.25 \\
(1.45)\end{array}$ \\
\hline Adjusted $\mathrm{R}^{2}$ & 0.75 & 0.78 & 0.78 & 0.78 & 0.78 & 0.78 & 0.41 & 0.43 & 0.44 & 0.45 & 0.46 & 0.46 \\
\hline \multicolumn{13}{|c|}{ B. Poor $(C=69)$} \\
\hline Income & $5.57 * * *$ & $\begin{array}{c}4.94 * * * \\
(0.82)\end{array}$ & $\begin{array}{c}4.97 * * * \\
(0.82)\end{array}$ & $3.92 * * *$ & $\begin{array}{l}3.35^{* *} \\
(140)\end{array}$ & $\begin{array}{c}3.44 * * \\
(147)\end{array}$ & $\begin{array}{l}0.57^{*} \\
(0.33)\end{array}$ & $\begin{array}{l}0.64^{*} \\
(0.36)\end{array}$ & $\begin{array}{l}0.70 * * \\
(0.34)\end{array}$ & $\begin{array}{c}0.52 \\
(0.48)\end{array}$ & $\begin{array}{l}-0.10 \\
(0.57)\end{array}$ & $\begin{array}{c}0.14 \\
(0.59)\end{array}$ \\
\hline Happiness & & $\begin{array}{l}16.17^{*} \\
(8.25)\end{array}$ & $\begin{array}{c}16.79 * * \\
(8.39)\end{array}$ & $\begin{array}{l}13.67 \\
(8.69)\end{array}$ & $\begin{array}{l}14.07 \\
(8.74)\end{array}$ & $\begin{array}{l}14.54 \\
(9.10)\end{array}$ & & $\begin{array}{l}-1.67 \\
(3.62)\end{array}$ & $\begin{array}{l}-0.12 \\
(3.45)\end{array}$ & $\begin{array}{l}-0.67 \\
(3.62)\end{array}$ & $\begin{array}{l}-0.23 \\
(3.55)\end{array}$ & $\begin{array}{c}1.04 \\
(3.64)\end{array}$ \\
\hline Income inequality & & & $\begin{array}{c}3.81 \\
(7.64)\end{array}$ & $\begin{array}{l}7.27 \\
(8.06)\end{array}$ & $\begin{array}{l}7.59 \\
(8.10)\end{array}$ & $\begin{array}{l}7.72 \\
(8.19)\end{array}$ & & & $\begin{array}{c}9.47 * * * \\
(3.14)\end{array}$ & $\begin{array}{c}10.08^{* * *} \\
(3.35)\end{array}$ & $\begin{array}{c}10.42 * * * \\
(3.29)\end{array}$ & $\begin{array}{c}10.79 * * * \\
(3.27)\end{array}$ \\
\hline Human capital & & & & $\begin{array}{l}12.71 \\
(9.87)\end{array}$ & $\begin{array}{c}10.31 \\
(10.44)\end{array}$ & $\begin{array}{c}9.87 \\
(10.74)\end{array}$ & & & & $\begin{array}{c}2.22 \\
(4.10)\end{array}$ & $\begin{array}{l}-0.39 \\
(4.24)\end{array}$ & $\begin{array}{l}-1.59 \\
(4.29)\end{array}$ \\
\hline$\%$ pop. with internet & & & & & $\begin{array}{l}3.85 \\
(5.31)\end{array}$ & $\begin{array}{c}4.16 \\
(5.56)\end{array}$ & & & & & $\begin{array}{l}4.18^{*} \\
(2.15)\end{array}$ & $\begin{array}{l}5.02 * * \\
(2.22)\end{array}$ \\
\hline Urbanisation & & & & & & $\begin{array}{l}-0.89 \\
(4.39)\end{array}$ & & & & & & $\begin{array}{l}-2.45 \\
(1.76)\end{array}$ \\
\hline Adjusted $\mathrm{R}^{2}$ & 0.43 & 0.46 & 0.45 & 0.46 & 0.45 & 0.44 & 0.03 & 0.02 & 0.13 & 0.12 & 0.15 & 0.16 \\
\hline \multicolumn{13}{|c|}{ C. $\operatorname{Rich}(C=61)$} \\
\hline Income & $\begin{array}{c}8.52 * * * \\
(0.92)\end{array}$ & $\begin{array}{c}5.54 * * * \\
(1.31)\end{array}$ & $\begin{array}{c}7.29 * * * \\
(1.45)\end{array}$ & $\begin{array}{c}5.72 * * * \\
(1.58)\end{array}$ & $\begin{array}{c}5.55^{* * *} \\
(1.63)\end{array}$ & $\begin{array}{c}5.56^{* * *} \\
(1.65)\end{array}$ & $\begin{array}{c}3.63^{* * * *} \\
(0.50)\end{array}$ & $\begin{array}{c}2.58 * * * \\
(0.73)\end{array}$ & $\begin{array}{c}2.34^{* * *} \\
(0.85)\end{array}$ & $\begin{array}{l}1.68 * \\
(0.95)\end{array}$ & $\begin{array}{c}1.42 \\
(0.97)\end{array}$ & $\begin{array}{c}1.39 \\
(0.97)\end{array}$ \\
\hline Happiness & & $\begin{array}{c}22.68^{* * *} \\
(7.46)\end{array}$ & $\begin{array}{c}17.26^{* *} \\
(7.50)\end{array}$ & $\begin{array}{c}16.46^{* * *} \\
(7.28)\end{array}$ & $\begin{array}{l}15.19^{*} \\
(7.84)\end{array}$ & $\begin{array}{l}15.22^{*} \\
(7.95)\end{array}$ & & $\begin{array}{l}8.04 * \\
(4.19)\end{array}$ & $\begin{array}{c}8.78^{* *} \\
(4.41)\end{array}$ & $\begin{array}{l}8.44 * \\
(4.37)\end{array}$ & $\begin{array}{c}6.43 \\
(4.65)\end{array}$ & $\begin{array}{c}6.04 \\
(4.68)\end{array}$ \\
\hline Income inequality & & & $\begin{array}{c}16.57 * * \\
(6.80)\end{array}$ & $\begin{array}{c}23.98 * * * \\
(7.44)\end{array}$ & $\begin{array}{c}24.77 * * * \\
(7.69)\end{array}$ & $\begin{array}{c}24.91 * * * \\
(8.50)\end{array}$ & & & $\begin{array}{l}-2.26 \\
(4.00)\end{array}$ & $\begin{array}{c}0.85 \\
(4.47)\end{array}$ & $\begin{array}{c}2.10 \\
(4.56)\end{array}$ & $\begin{array}{c}0.35 \\
(5.01)\end{array}$ \\
\hline Human capital & & & & $14.92 * *$ & $13.92 *$ & $13.91^{*}$ & & & & 6.27 & 4.69 & 4.85 \\
\hline & & & & $(6.94)$ & $(7.32)$ & $(7.39)$ & & & & (4.17) & $(4.34)$ & $(4.36)$ \\
\hline$\%$ pop. with internet & & & & & $\begin{array}{c}2.58 \\
(5.61)\end{array}$ & $\begin{array}{c}2.70 \\
(6.49)\end{array}$ & & & & & $\begin{array}{c}4.09 \\
(3.33)\end{array}$ & $\begin{array}{c}2.48 \\
(3.82)\end{array}$ \\
\hline Urbanisation & & & & & & $\begin{array}{l}-0.15 \\
(3.76)\end{array}$ & & & & & & $\begin{array}{l}1.90 \\
(2.22)\end{array}$ \\
\hline Adjusted $\mathrm{R}^{2}$ & 0.58 & 0.64 & 0.66 & 0.68 & 0.68 & 0.67 & 0.47 & 0.49 & 0.48 & 0.50 & 0.50 & 0.50 \\
\hline
\end{tabular}


Notes:

1. Coefficients are elasticities $\times 100$

2. Heteroscedasticity-robust standard errors in parentheses. Statistical significance indicator: ${ }^{*} \mathrm{p}<0.1 ;{ }^{* *} \mathrm{p}<0.05 ;{ }^{* * *} \mathrm{p}<0.01$. Intercepts are included but their estimates not presented.

3. There are $C=69$ poor and $C=61$ rich countries: The sample size is determined by data availability. "Income" is defined as $Y_{c} / \bar{Y}$, the real per capita consumption in country $c$ relative to the cross-country geometric mean income, $\bar{Y}$. "Happiness" is a "life-evaluation" index. "Income inequality" is the Gini index. "Human capital" is the Human Capital Index. "\% pop. with internet" is the percentage share of people who have used the Internet in the last 3 months. "Urbanisation" is the share of people living in urban areas.

4. All variables are log-transformed, are from the World Bank (2021) and refer to 2017, except for the happiness index, which is from World Happiness Report (2021) and refers to 2018 - 2020. For more details, see Appendix A5. 
Table 10. Price Correlations

\begin{tabular}{|c|c|c|c|c|c|c|c|c|c|}
\hline & $\begin{array}{c}\text { Food } \\
(1)\end{array}$ & $\begin{array}{c}\text { Clothing } \\
\text { (2) }\end{array}$ & $\begin{array}{c}\text { Housing } \\
\text { (3) }\end{array}$ & $\begin{array}{c}\text { Furnishings } \\
\text { (4) }\end{array}$ & $\begin{array}{c}\text { Health } \\
(5)\end{array}$ & $\begin{array}{c}\text { Education } \\
(6)\end{array}$ & $\begin{array}{c}\text { Restaurants } \\
(7)\end{array}$ & $\begin{array}{c}\text { Recreation } \\
(8)\end{array}$ & $\begin{array}{c}\text { Miscellaneous } \\
\text { (9) }\end{array}$ \\
\hline Income elasticity & 0.37 & 0.91 & 1.19 & 1.07 & 1.28 & 1.05 & 1.34 & 1.41 & 1.19 \\
\hline \multicolumn{10}{|c|}{ A. All countries $(C=176)$} \\
\hline 1. Food & & -0.12 & -0.11 & 0.04 & -0.05 & -0.19 & -0.30 & -0.20 & -0.26 \\
\hline 2. Clothing & & & 0.68 & 0.24 & -0.31 & 0.45 & 0.17 & 0.05 & 0.41 \\
\hline 3. Housing & & & & 0.29 & -0.43 & 0.35 & 0.16 & -0.06 & 0.36 \\
\hline 4. Furnishings & & & & & -0.07 & 0.07 & 0.09 & -0.19 & 0.12 \\
\hline 5. Health & & & & & & -0.22 & 0.03 & 0.18 & -0.03 \\
\hline 6. Education & & & & & & & 0.35 & 0.33 & 0.42 \\
\hline 7. Restaurants & & & & & & & & 0.58 & 0.60 \\
\hline 8. Recreation & & & & & & & & & 0.58 \\
\hline Income & -0.16 & 0.52 & 0.51 & 0.09 & -0.14 & 0.58 & 0.68 & 0.57 & 0.71 \\
\hline \multicolumn{10}{|c|}{ B. Poor $(C=88)$} \\
\hline 1. Food & & -0.07 & -0.07 & 0.00 & -0.20 & -0.03 & 0.02 & -0.02 & -0.08 \\
\hline 2. Clothing & & & 0.68 & 0.11 & -0.39 & 0.36 & -0.05 & -0.03 & 0.40 \\
\hline 3. Housing & & & & 0.23 & -0.50 & 0.36 & -0.04 & -0.20 & 0.36 \\
\hline 4. Furnishings & & & & & -0.01 & 0.05 & 0.26 & -0.10 & 0.35 \\
\hline 5. Health & & & & & & -0.15 & 0.24 & 0.43 & 0.11 \\
\hline 6. Education & & & & & & & -0.10 & 0.10 & 0.20 \\
\hline 7. Restaurants & & & & & & & & 0.26 & 0.30 \\
\hline 8. Recreation & & & & & & & & & 0.32 \\
\hline Income & 0.10 & 0.56 & 0.58 & 0.19 & -0.21 & 0.32 & 0.29 & 0.10 & 0.49 \\
\hline \multicolumn{10}{|c|}{ C. $\operatorname{Rich}(C=88)$} \\
\hline 1. Food & & -0.07 & -0.09 & 0.08 & 0.08 & -0.25 & -0.50 & -0.23 & -0.39 \\
\hline 2. Clothing & & & 0.46 & 0.43 & -0.19 & 0.20 & -0.24 & -0.45 & -0.11 \\
\hline 3. Housing & & & & 0.41 & -0.31 & -0.11 & -0.18 & -0.53 & -0.17 \\
\hline 4. Furnishings & & & & & -0.14 & 0.04 & -0.12 & -0.38 & -0.18 \\
\hline 5. Health & & & & & & -0.37 & -0.16 & 0.04 & -0.25 \\
\hline 6. Education & & & & & & & 0.29 & 0.08 & 0.18 \\
\hline 7. Restaurants & & & & & & & & 0.51 & 0.54 \\
\hline 8. Recreation & & & & & & & & & 0.53 \\
\hline Income & -0.36 & -0.21 & -0.22 & -0.08 & -0.14 & 0.42 & 0.66 & 0.61 & 0.57 \\
\hline
\end{tabular}

Note: This table presents the correlations (i) among relative prices, $\log p_{i c}-\sum_{j=1}^{9} w_{i c} \log p_{j c}, i=1, \cdots, 9$, and (ii) between prices and income, $\log \left(Y_{c} / \bar{Y}\right)$. Income elasticities (in the first row) are from panel A, column 6 (all countries) of Table 6 . Rich countries are those in the upper two income quartiles, poor countries are in the lower two quartiles. 
Table 11. Food and Income

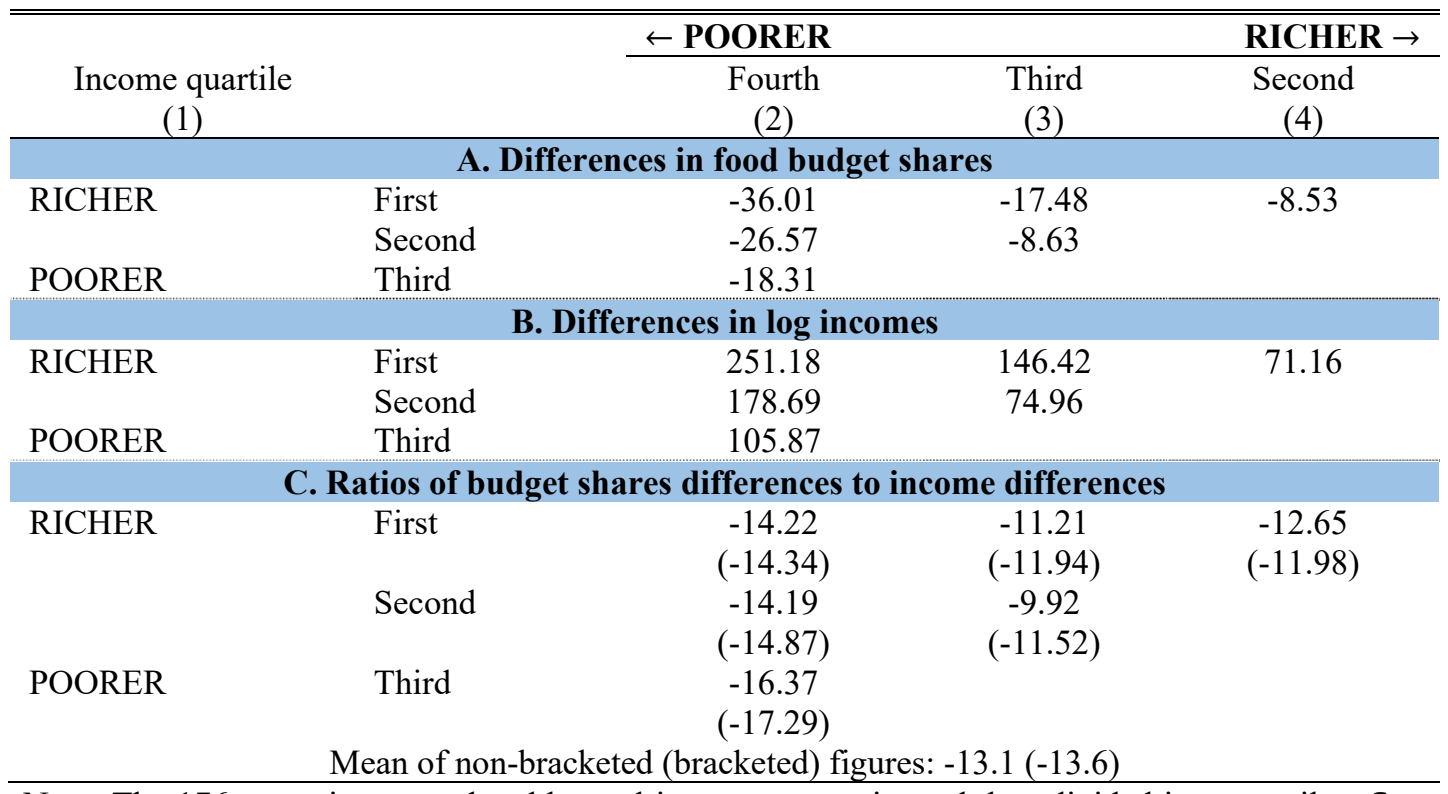

Note: The 176 countries are ordered by real income per capita and then divided into quartiles, $\boldsymbol{S}_{1}, \cdots$, $\boldsymbol{S}_{4}$. The $(i, j)^{\text {th }}$ element of panel A is the median of the food budget share of country $c$ less that in $d$, where $c \in \boldsymbol{S}_{g}, d \in \boldsymbol{S}_{h}, g \neq h$. Panels B and C are defined similarly to panel A. The entries in parentheses in panel $\mathrm{C}$ are ratios of the corresponding elements of panel A to those of panel B. All entries are $\times 100$.

Table 12. Food and Quality in Rich and Poor Countries

\begin{tabular}{|c|c|c|c|c|c|c|c|}
\hline \multirow[b]{2}{*}{$\begin{array}{c}\text { Country } \\
\text { (1) }\end{array}$} & \multirow[b]{2}{*}{$\begin{array}{l}\text { Real } \\
\text { income } \\
\text { (\$ p.c.) } \\
(2) \\
\end{array}$} & \multirow[b]{2}{*}{$\begin{array}{c}\text { Quality of } \\
\text { consumption } \\
y_{\eta q} \\
(3) \\
\end{array}$} & \multicolumn{4}{|c|}{ Food components } & \multirow[b]{2}{*}{$\begin{array}{c}\text { Share of } \\
\text { food in } \\
\text { quality }(\%) \\
y_{F q} / y_{\eta q} \\
(\times 100) \\
(8)\end{array}$} \\
\hline & & & $\begin{array}{c}\text { Budget } \\
\text { share } \\
\widehat{w}_{F} \\
(4)\end{array}$ & $\begin{array}{c}\text { Income } \\
\text { elasticity } \\
\eta_{F} \\
(5)\end{array}$ & $\begin{array}{l}\text { Consumption } \\
\Delta \log q_{F} \\
-\Delta \log Q \\
\text { (6) }\end{array}$ & $\begin{array}{c}\text { Quality } \\
y_{F q}= \\
\widehat{w}_{F}\left(\eta_{F}\right. \\
-1)\left(\Delta \log q_{F}-\Delta \log Q\right) \\
\text { (7) }\end{array}$ & \\
\hline UAE & 26,481 & 0.115 & 0.123 & 0.026 & -0.837 & 0.100 & 87.6 \\
\hline Mozambique & 779 & -0.179 & 0.517 & 0.760 & 0.581 & -0.069 & 38.9 \\
\hline
\end{tabular}

Note: The overall index of quality of consumption, $y_{\eta q}$ of column 3 , is the weighted covariance $y_{\eta q}=$ $\sum_{i=1}^{9} \widehat{w}_{i}\left(\eta_{i}-1\right)\left(\Delta \log q_{i}-\Delta \log Q\right)$. See notes to Table 8 for details.

Table 13. Food and Quality across the Income Distribution

\begin{tabular}{|c|c|}
\hline $\begin{array}{c}\text { Income quartile } \\
\text { (1) }\end{array}$ & $\begin{array}{c}\text { Food contribution to quality } \\
\text { of consumption basket } \\
\text { (Percentage share) } \\
(2)\end{array}$ \\
\hline 1. Richest & $83.4(17.3)$ \\
\hline 2 & $74.8(17.0)$ \\
\hline 3 & $59.2(19.5)$ \\
\hline 4. Poorest & $46.6(11.0)$ \\
\hline
\end{tabular}

Note: The elements in this table are quartile medians of the percentage share $100 \times \frac{\widehat{w}_{F}\left(\eta_{F}-1\right)\left(\Delta \log q_{F}-\Delta \log Q\right)}{y_{\eta q}}, \quad$ where $\quad y_{\eta q}=\sum_{i=1}^{9} \widehat{w}_{i}\left(\eta_{i}\right.$ 1) $\left(\Delta \log q_{i}-\Delta \log Q\right)$ is the index of the quality of the consumption basket. Cases omitted when ratio is negative. Standard deviations in parentheses. 
Table 14. Global Food Demand

\begin{tabular}{c|c|cc|c}
\hline \hline $\begin{array}{l}\text { Income } \\
\text { quartile }\end{array}$ & $2017(\%)$ & \multicolumn{2}{|c}{$\begin{array}{c}\text { Change over } \\
2017-2026\end{array}$} & $\begin{array}{c}\text { COVID-19 } \\
\text { effect } \\
\text { (1) }\end{array}$ \\
\multicolumn{5}{|c|}{ A. Growth rates } \\
ICP & IMF & IMF - ICP \\
Q1 & - & 2.6 & 2.3 & -0.3 \\
Q2 & - & 20.9 & 10.8 & -10.0 \\
Q3 & - & 36.2 & 22.6 & -13.6 \\
Q4 & - & 47.8 & 34.5 & $-\mathbf{1 3 . 4}$ \\
\hline \multicolumn{5}{c}{ B. Shares } \\
Q1 & 27.8 & -4.9 & -3.1 & 1.7 \\
Q2 & 24.0 & -0.6 & -0.9 & -0.3 \\
Q3 & 39.0 & 3.8 & 2.5 & -1.3 \\
Q4 & 9.1 & 1.7 & 1.5 & -0.2 \\
\hline
\end{tabular}

Notes: This table presents future food demand for countries in income quartile $g, Q_{F}^{g}=\sum_{c \in S_{g}} N_{c} q_{F, c}(g=1, \ldots, 4)$, where $N_{c}$ is the population of country $c$; $q_{F, c}$ is per capita food consumption in $c$; and $\boldsymbol{S}_{g}$ is the set of countries in income quartile $g$. Food demand in $c, q_{F, c}$, is from estimates of the differential demand model with homogeneity and symmetry imposed (panel B of Table 4) and income growth rates from the ICP (World Bank, 2020) and IMF (2021). In both sets of projections, growth in prices is from the ICP; and population is the medium scenario of the United Nations (2019).

1. Column 2: This gives the 2017 shares of $Q_{F}^{g}$ in the world total, $\frac{Q_{F, 2017}^{g}}{\sum_{g=1}^{4} Q_{F, 2017}^{g}}$.

2. Columns 3 - 4: Panel A, growth in $Q_{F}^{g}$ over 2017 - 2026, $100 \times\left(\log Q_{F, 2026}^{g}-\log Q_{F, 2017}^{g}\right)$. Panel $\mathrm{B}, \quad$ corresponding changes in quartile shares in global food consumption, $100 \times$ $\left(\frac{Q_{F, 2026}^{g}}{\sum_{g=1}^{4} Q_{F, 2026}^{g}}-\frac{Q_{F, 2017}^{g}}{\sum_{g=1}^{4} Q_{F, 2017}^{g}}\right)$.

3. Column 5: The difference between the projections based on the ICP's and IMF's data, interpreted as an approximation of the COVID-19 effect on food consumption. 
Figure 1. Illustrative Estimates, Multi-Step Income Comparisons

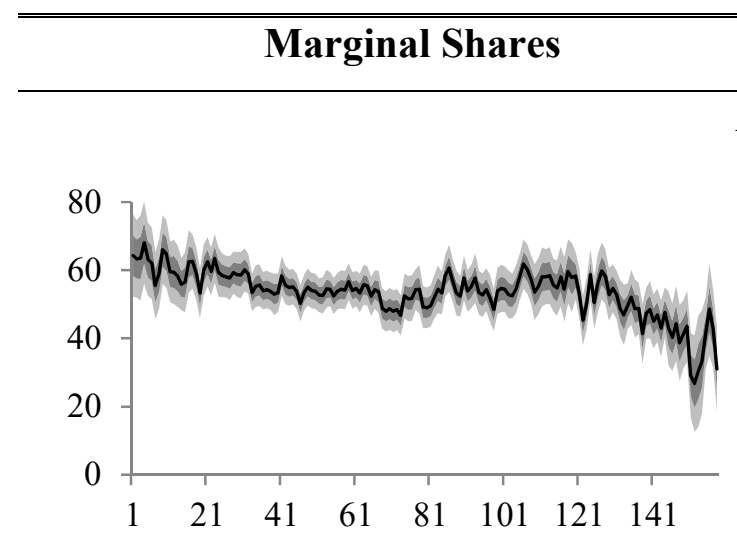
Own-Slutsky Coefficients

\section{A. Food}

\section{B. Clothing}
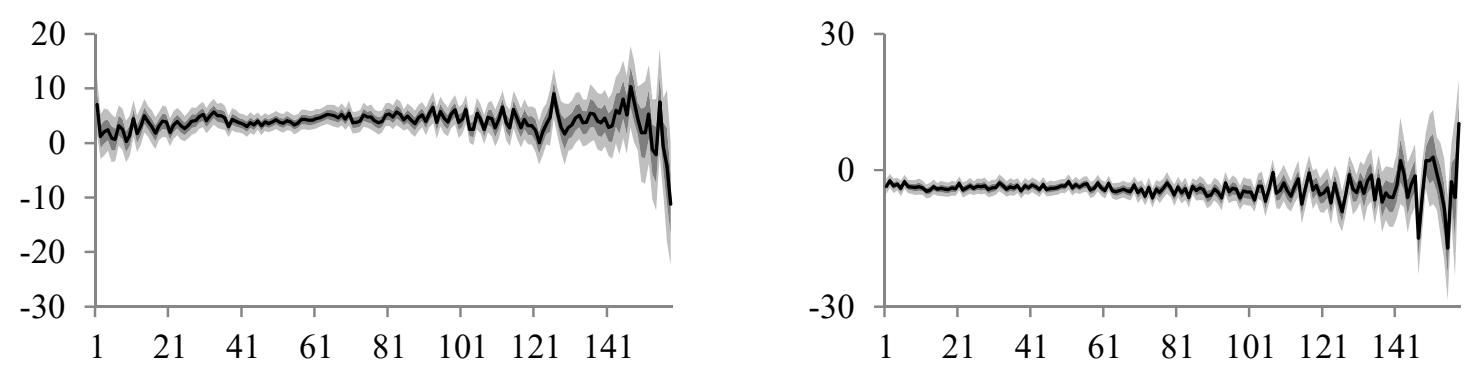

\section{Housing}
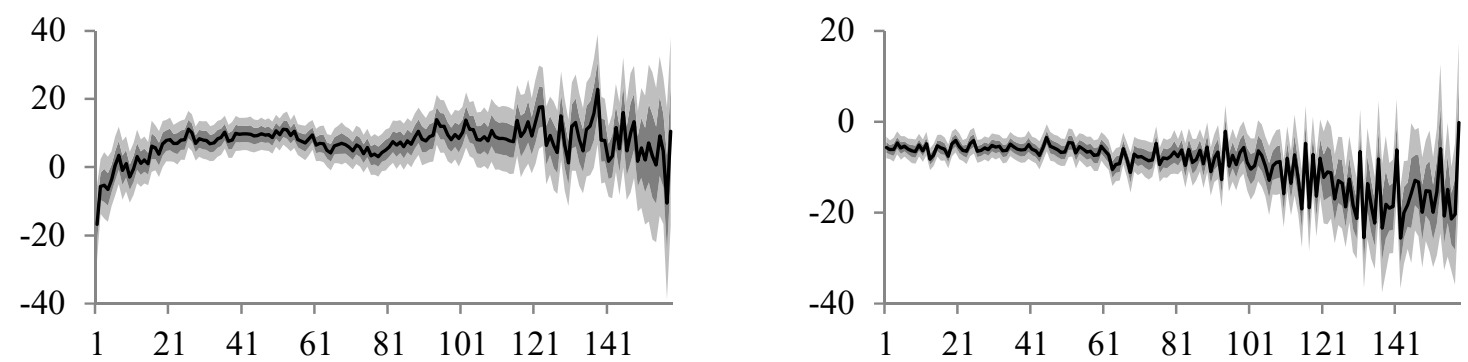

\section{Furnishings}
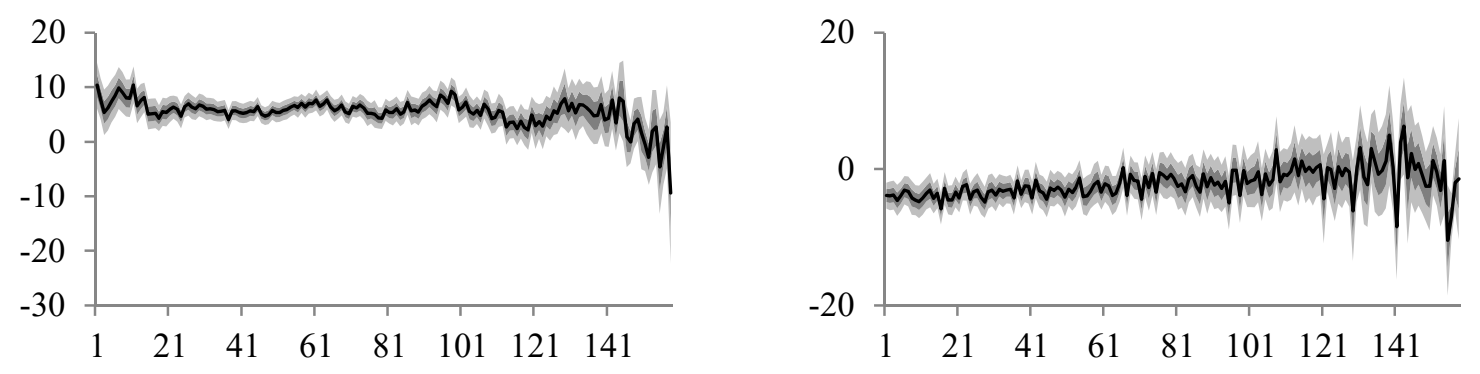

\section{E. Health}
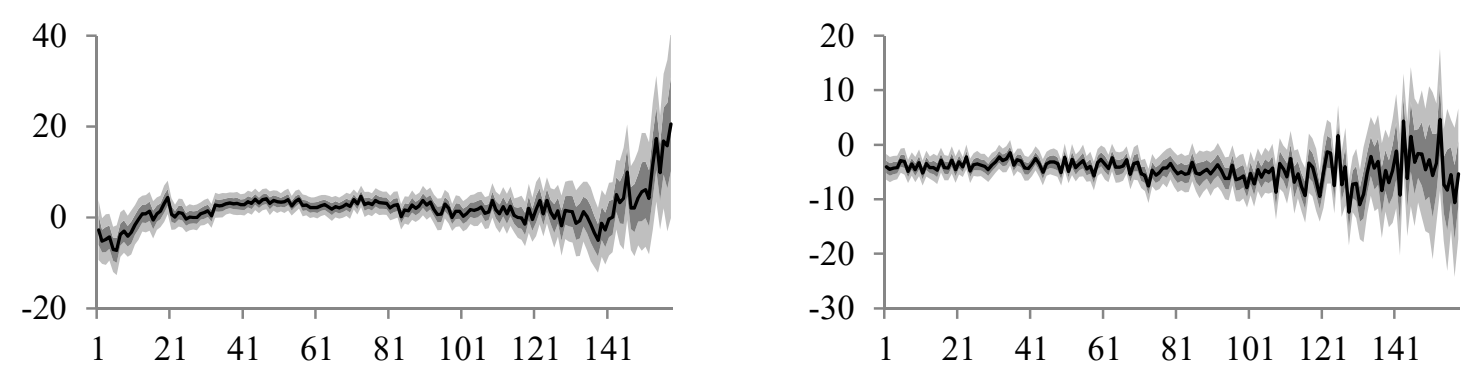
Figure 1. Illustrative Estimates, Multi-Step Income Comparisons (cont'd)

Marginal shares

Own-Slutsky Coefficients

\section{F. Recreation}
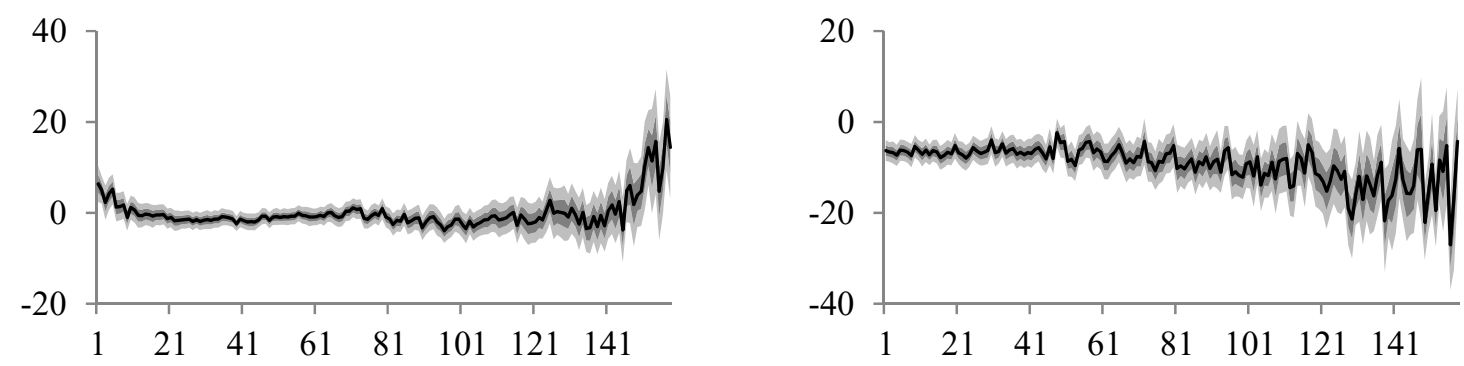

\section{G. Education}
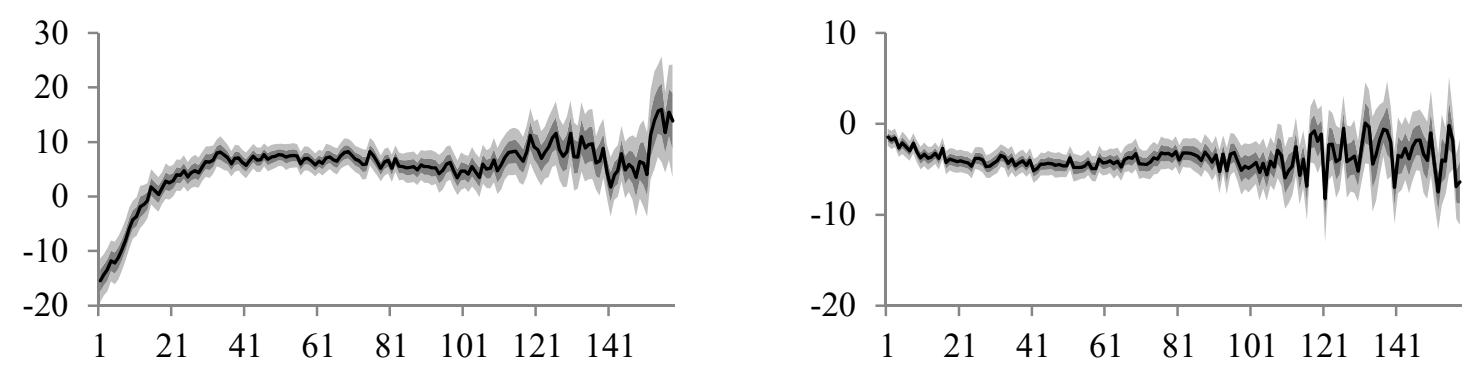

\section{H. Restaurants}
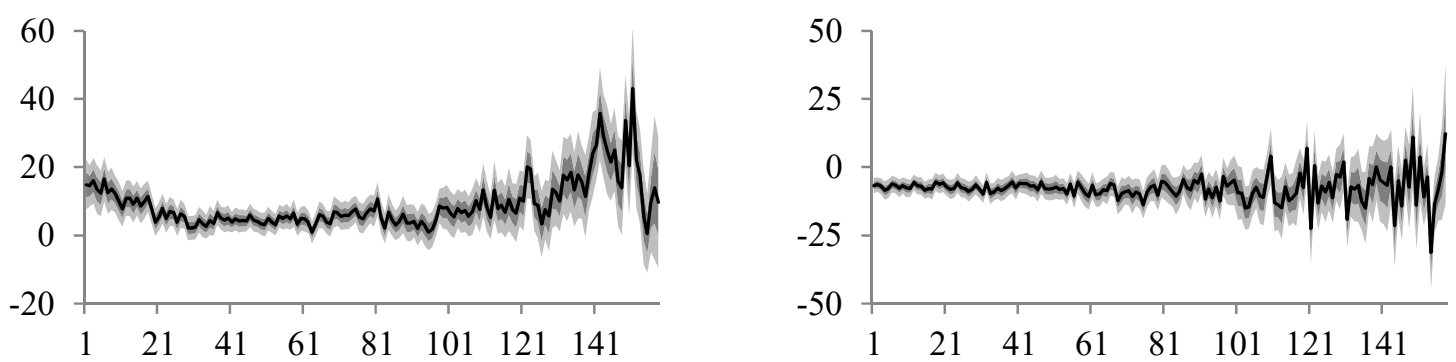

\section{Miscellaneous}
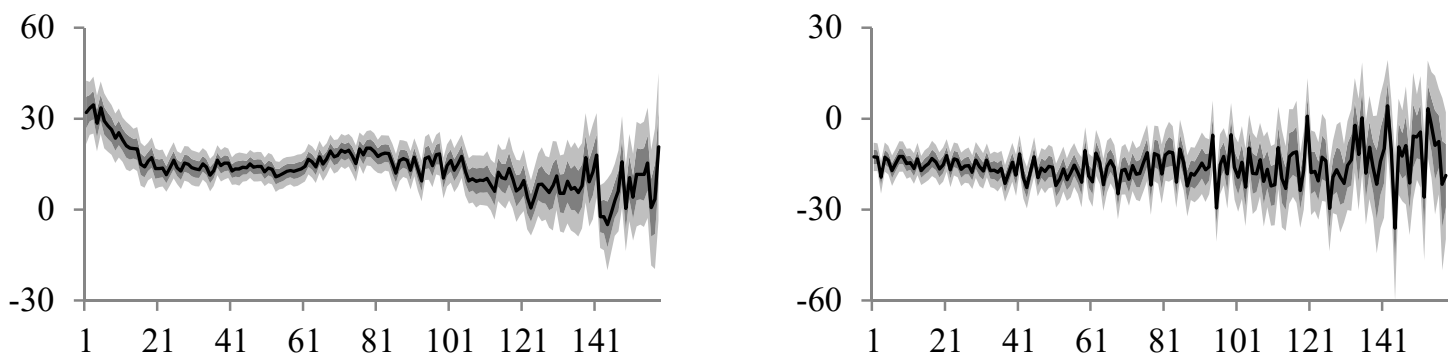

Note: The solid line is the point estimate corresponding to the income gap between country pairs (the distance between ranks on the income scale) given on the horizontal axis. The dark (light) grey shadings represent the $\pm 1 \mathrm{SE}$ ( $\pm 2 \mathrm{SE}$ ) band.

Source: Clements and Si (2018). 
Figure 2. Budget Shares and Income

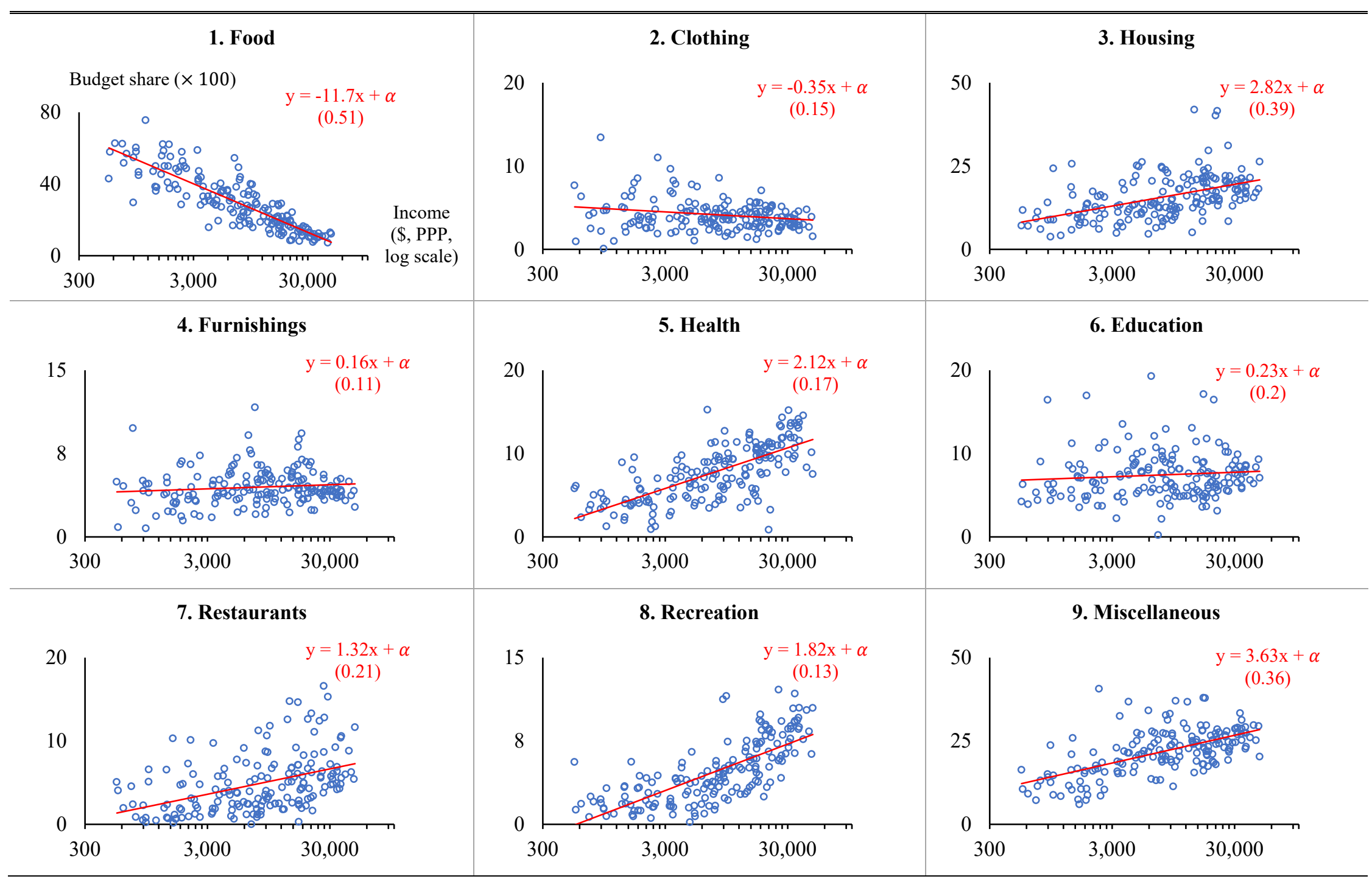

Note: The budget share of item $i$ is expenditure $\left(p_{1} q_{1}\right)$ as a proportion of total, $w_{i c}=p_{1} q_{1} / \sum_{i=1}^{9} p_{i} q_{i}$. Heteroscedasticity-robust standard errors in parentheses. 
Figure 3. Dispersion of Prices and Quantities

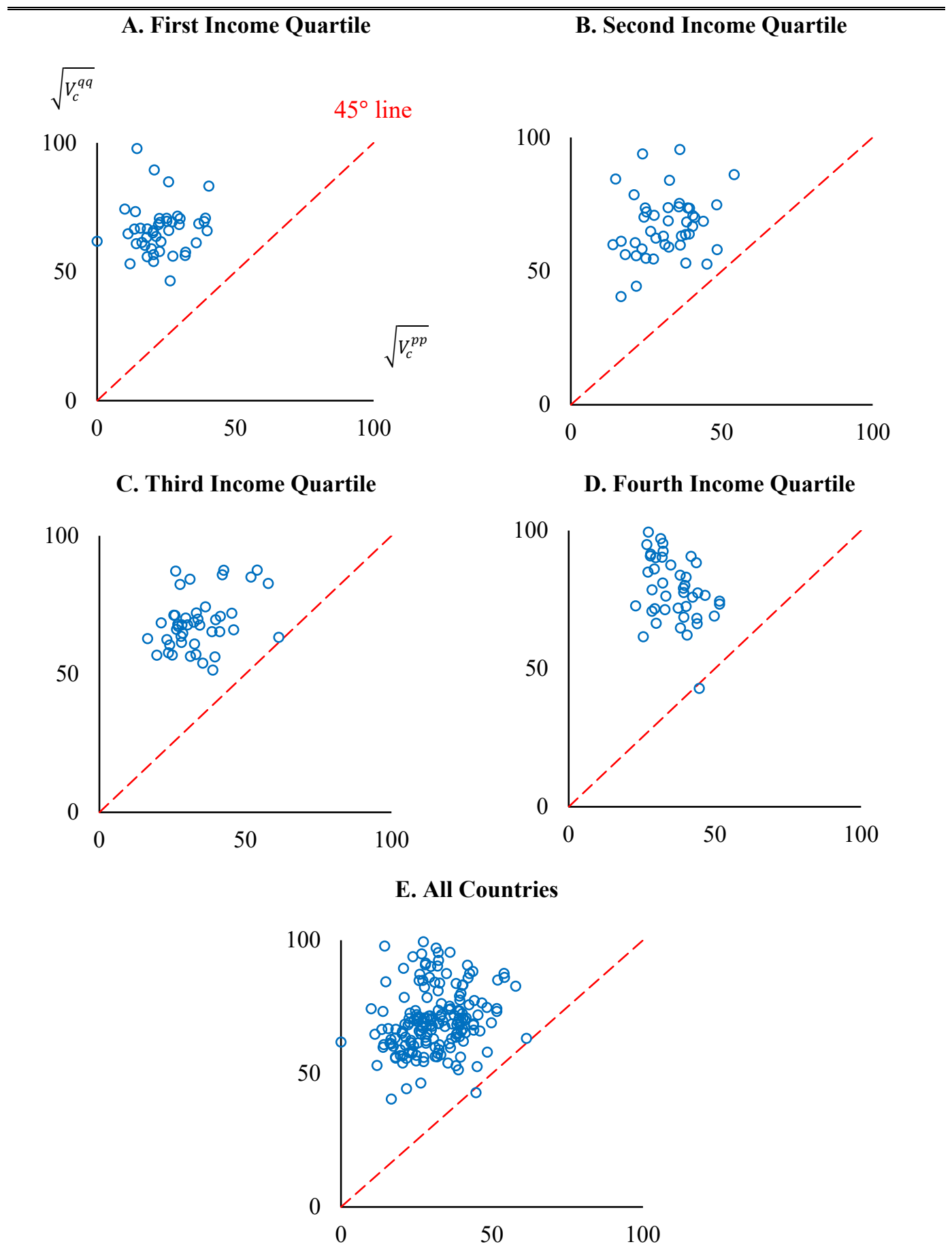

Note: The Divisia price (horizontal axis) and quantity (vertical axis) standard deviations are defined as in Table 2. All values are multiplied by 100 . 
Figure 4. Prices and Quantities

\begin{tabular}{|c|c|c|c|}
\hline & $\begin{array}{c}\text { Poor } \\
(C=88)\end{array}$ & $\begin{array}{c}\text { Rich } \\
(C=88)\end{array}$ & $\begin{array}{l}\text { All countries } \\
\quad(C=176)\end{array}$ \\
\hline 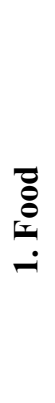 & 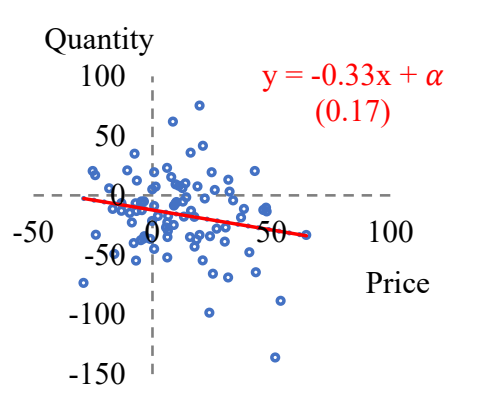 & 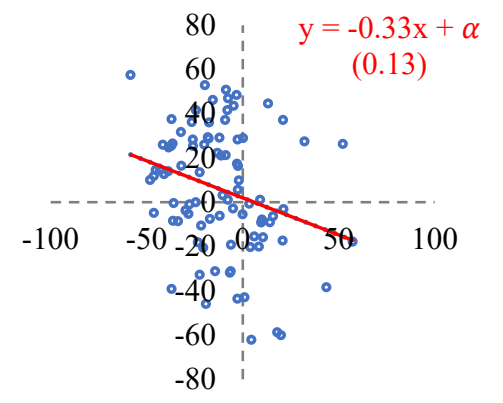 & 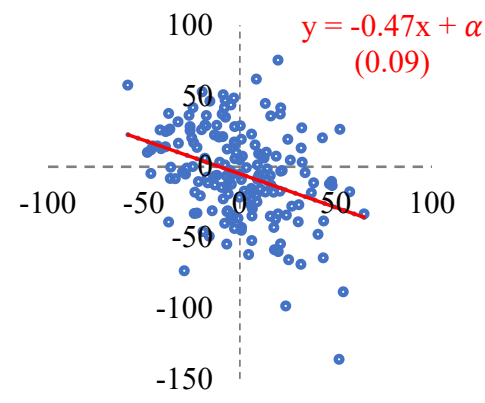 \\
\hline 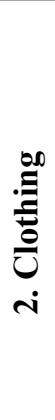 & 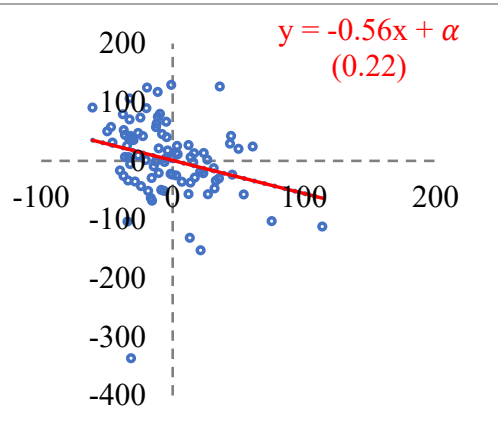 & 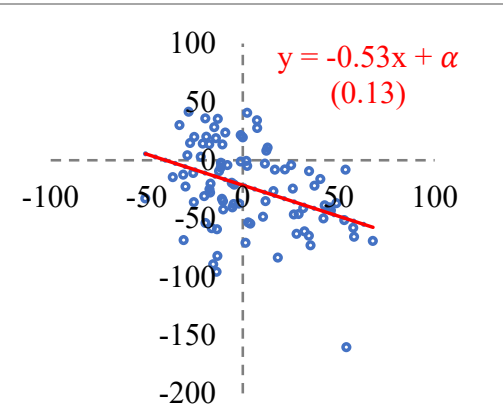 & 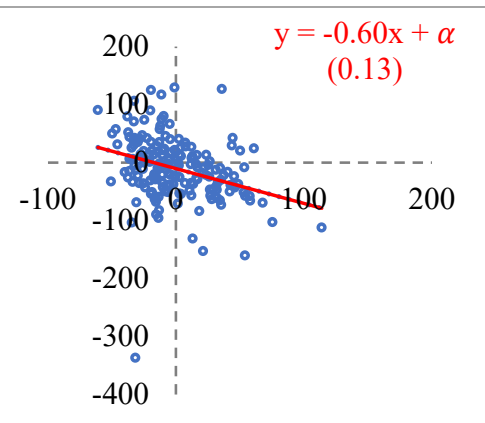 \\
\hline 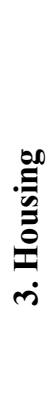 & 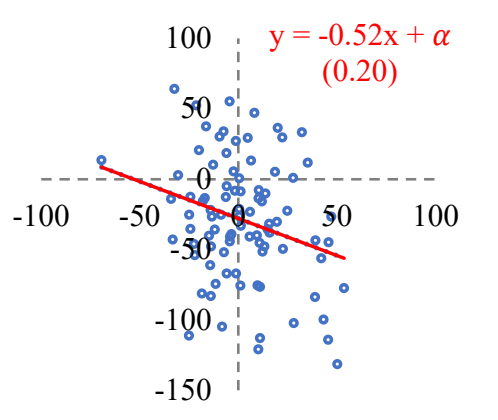 & 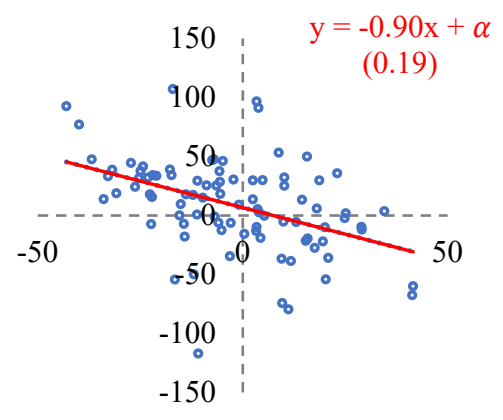 & 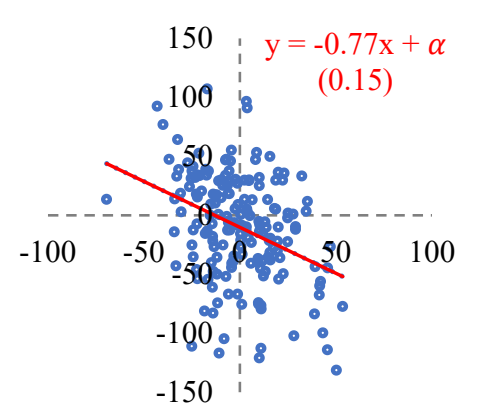 \\
\hline 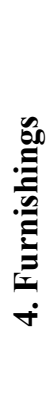 & 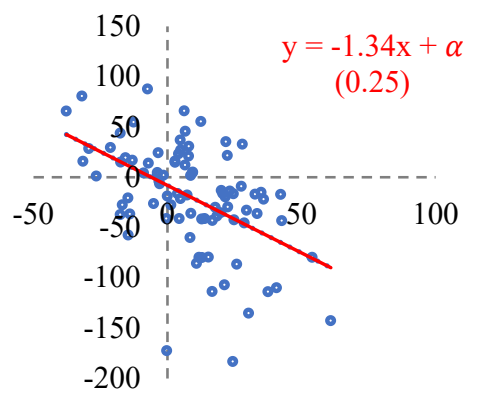 & 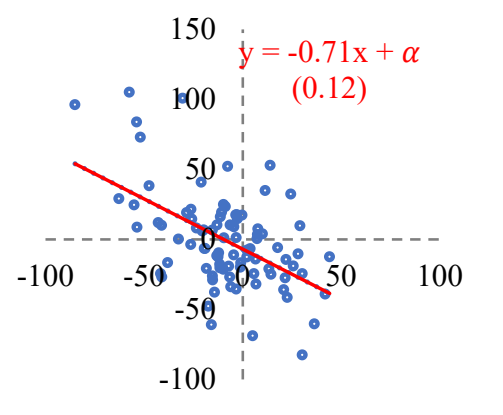 & 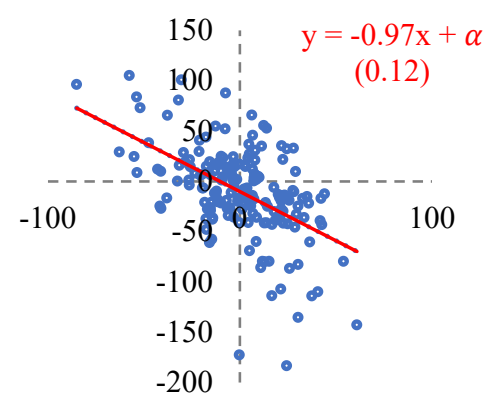 \\
\hline 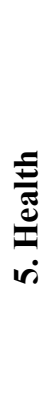 & 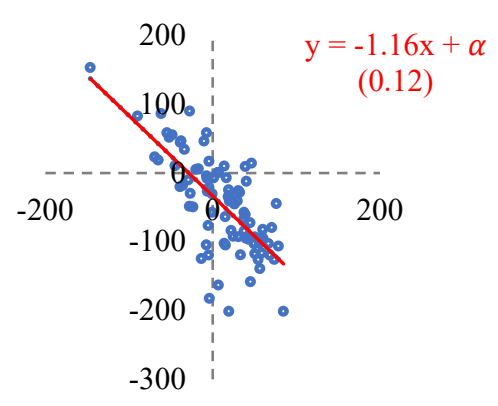 & 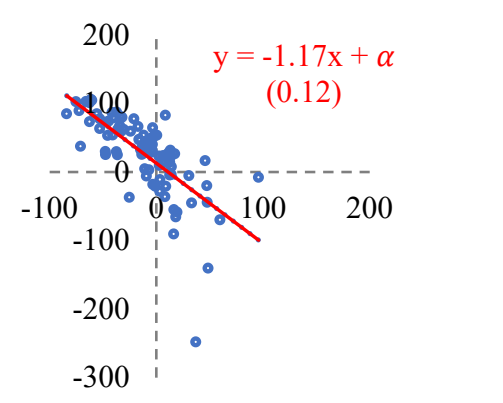 & 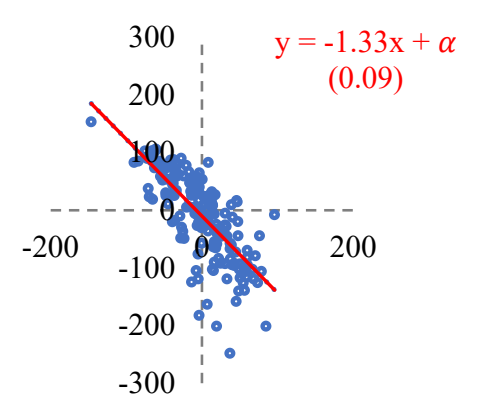 \\
\hline
\end{tabular}


Figure 4. Prices and Quantities (cont'd)

\begin{tabular}{|c|c|c|c|}
\hline & $\begin{array}{c}\text { Poor } \\
(C=88)\end{array}$ & $\begin{array}{c}\text { Rich } \\
(C=88)\end{array}$ & $\begin{array}{l}\text { All countries } \\
\quad(C=176)\end{array}$ \\
\hline 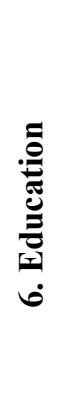 & 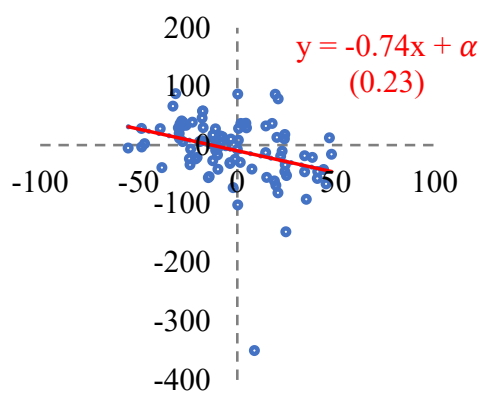 & 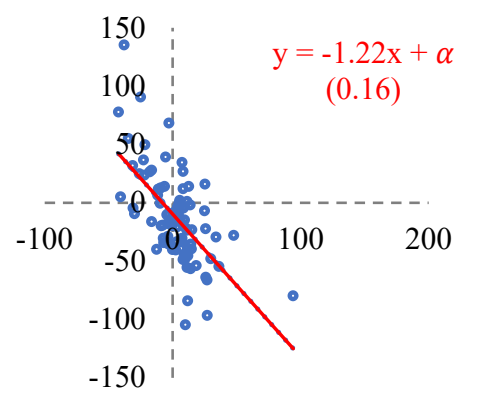 & 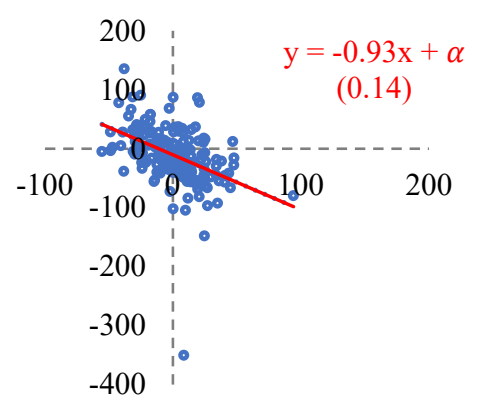 \\
\hline 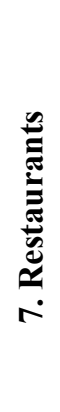 & 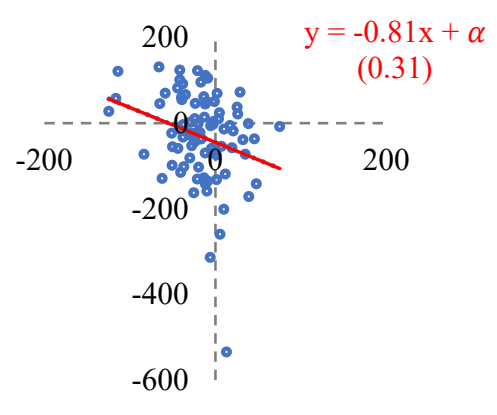 & 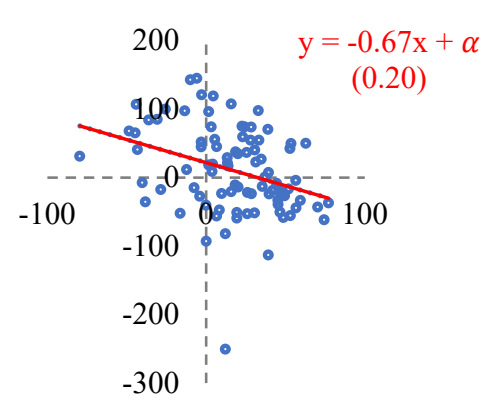 & $\begin{array}{l}y=-0.32 \mathrm{x}+\alpha \\
0.18) \\
0\end{array}$ \\
\hline 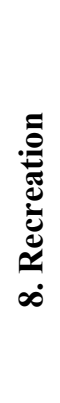 & 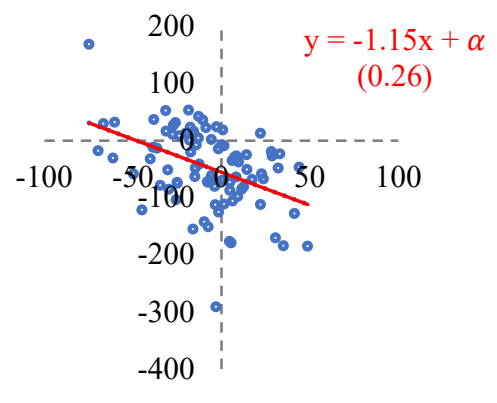 & 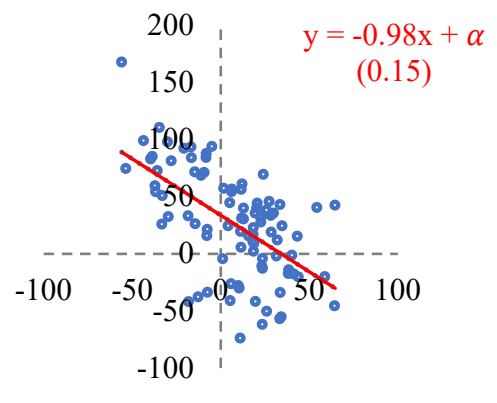 & 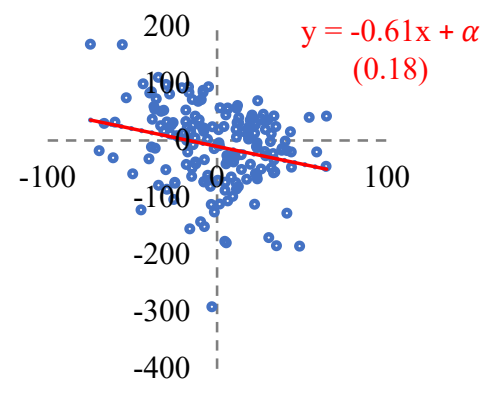 \\
\hline 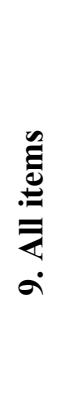 & 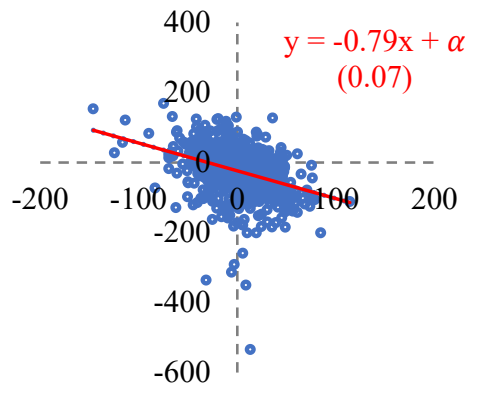 & 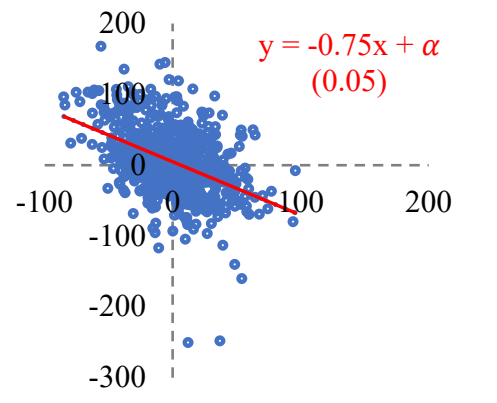 & 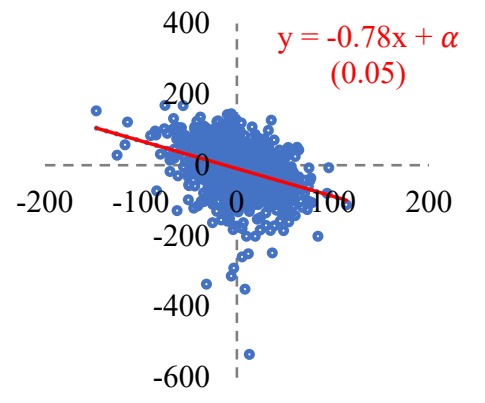 \\
\hline
\end{tabular}

Notes:

1. The variable on the horizontal axis is the relative price of item $i, \Delta \log p_{i c}-\Delta \log p_{9 c}=\log p_{i c}-\log p_{9 c}+\operatorname{constant}(i=$ $1, \ldots, 8)$.

2. For goods other than "food", the variable on the vertical axis is the relative quantity $\Delta \log q_{i c}-\Delta \log Q_{c}$, where $\Delta \log q_{i c}=$ $\log q_{i c}-\log q_{i}^{*}$ is the difference between consumption of good $i$ in country $c$ and the world, and $\Delta \log Q_{c}=\sum_{i=1}^{9} \bar{w}_{i c} \Delta \log q_{i c}$, with $\bar{w}_{i c}=\frac{1}{2}\left(w_{i c}+w_{i}^{*}\right)$. To allow for a less-than-unity income elasticity for "food", its relative quantity is defined as $\Delta \log q_{i c}-1 / 2 \Delta \log Q_{c}$.

3. Variables on both axes are multiplied by 100 .

4. Heteroscedasticity-robust standard errors in parentheses. 
Figure 5. All-Items-All-Countries-Price-Quantity Scatter

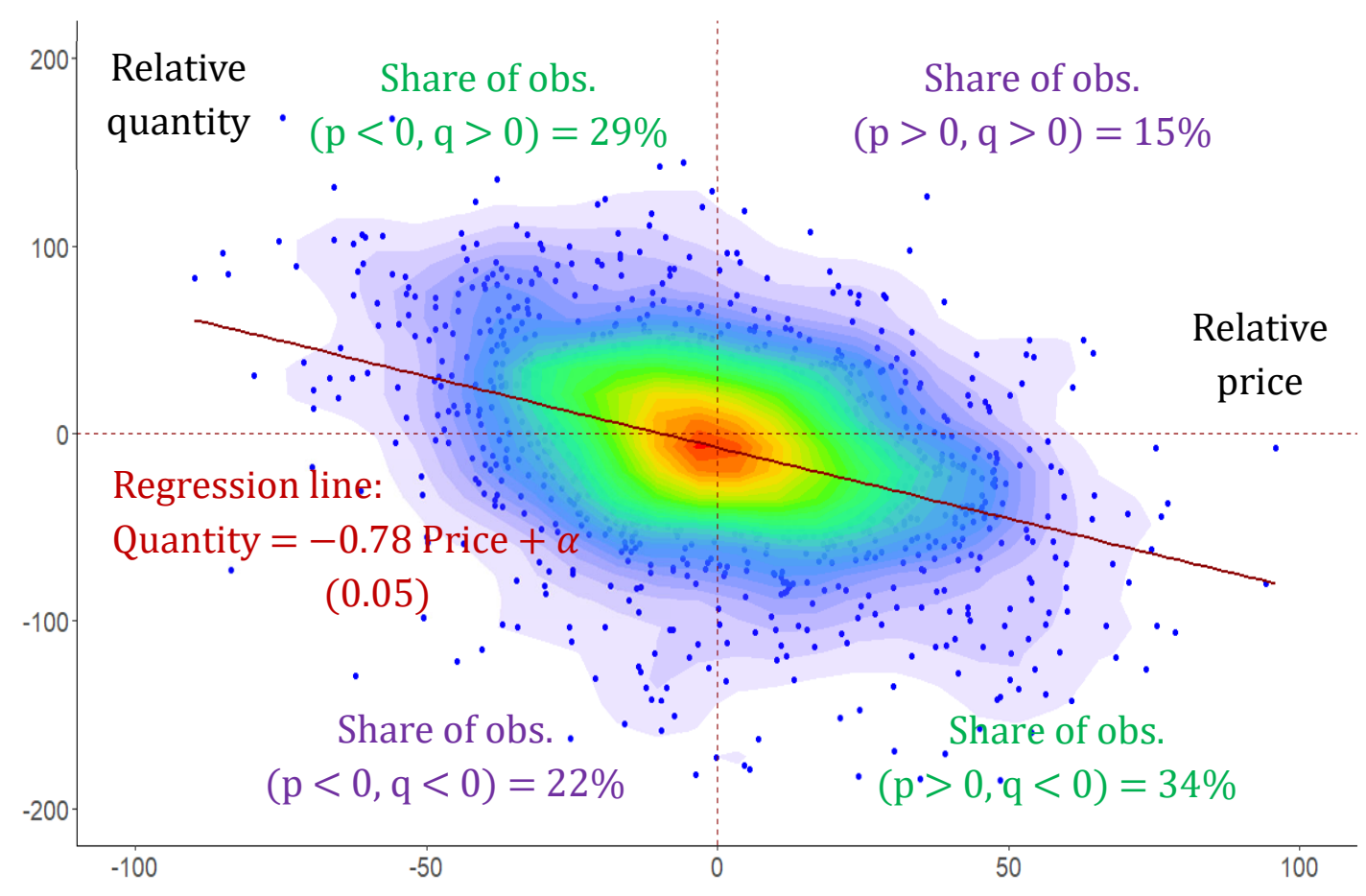

Note: This figure is a blow-up of the plot in the third column and ninth row of Figure 4. This is a heat map in which higher density is located nearer the centre. Extreme values of prices and quantities are not shown. There are $176 \times 8=1,408$ country-commodity observations in this plot. See notes to Figure 4 for details. The share of observations in each of the four quadrants is also recorded here.

Figure 6. Budget and Marginal Shares

A. Budget shares (\%)

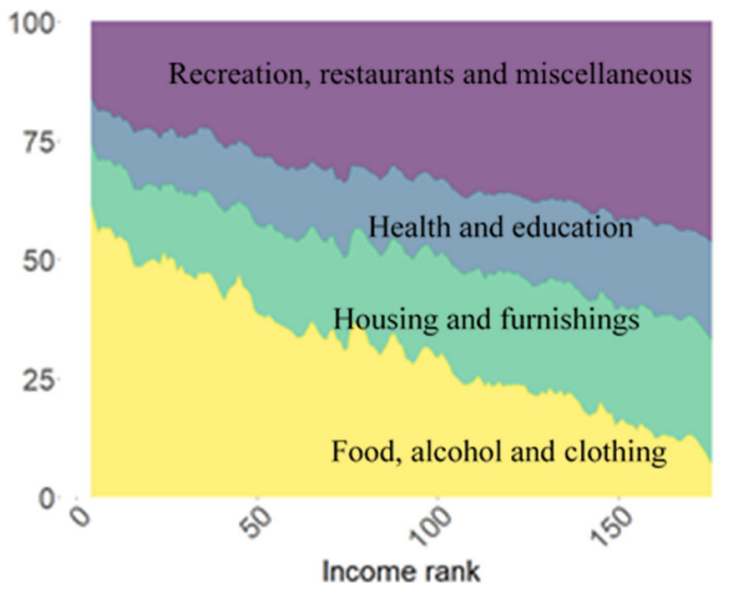

B. Marginal shares (\%)

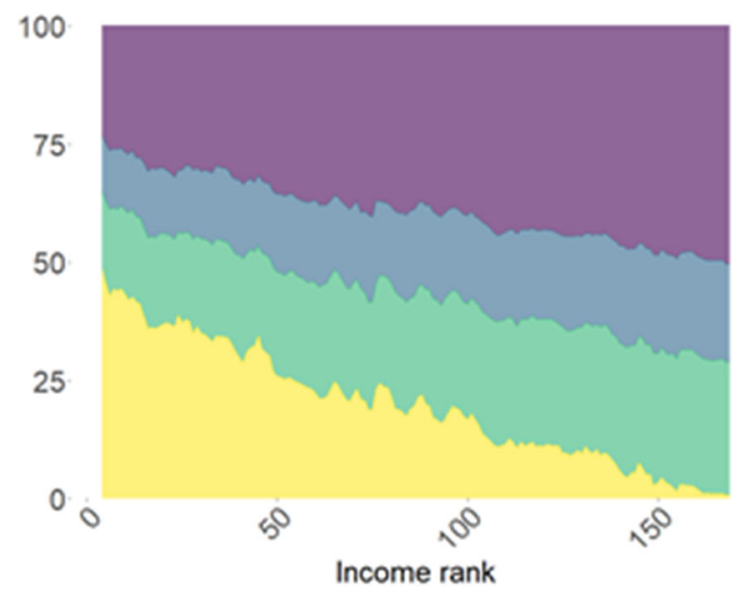

Notes:

1. Panel A: The budget share is the good's share of total expenditure.

2. Panel B: The marginal share is the good's share in a $\$ 1$-rise in total expenditure, and takes the form $\theta_{i c}=\widehat{w}_{i c}+\beta_{i}$, where $\beta_{i}$ estimated income coefficient of the good, obtained from panel B of Table 4; and $\widehat{w}_{i c}$ is the corresponding predicted budget share.

3. The 9 commodities are aggregated into 4 groups, and all values are 4-country moving averages. 
Figure 7. Quality, Income and Prices

A. Consumption

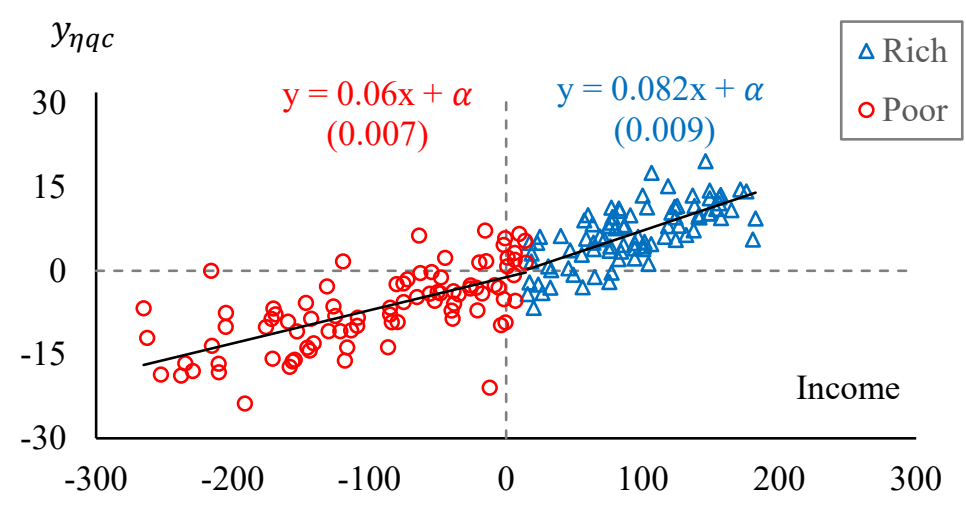

B. Prices

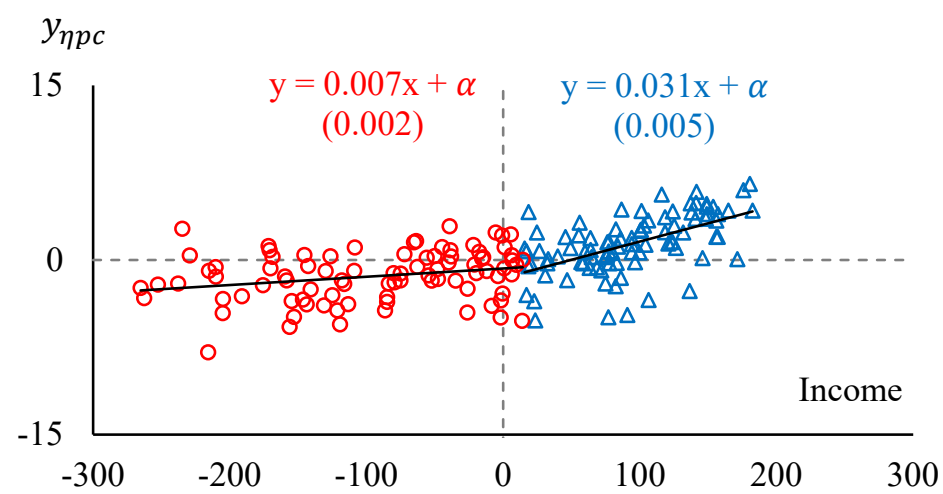

\section{Quality Demand Curves}

C1. $\underline{\text { Poor }}$

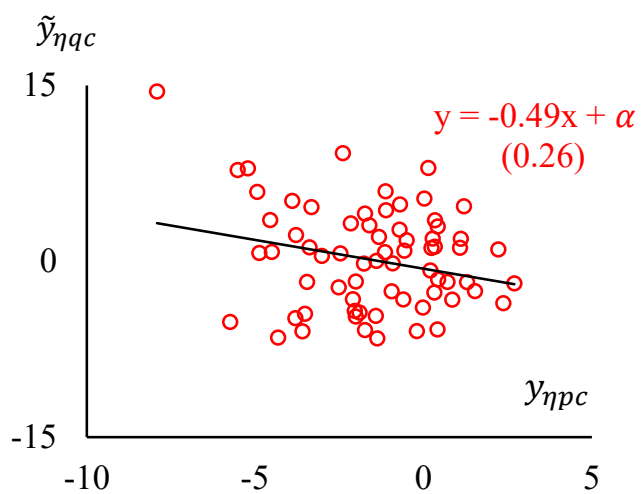

C2. $\underline{\text { Rich }}$

Notes:

1. Panels A and B: These graphs plot the index of the quality of consumption and its price against income. Income is defined as $\log \left(Y_{c} / \bar{Y}\right)$, the logarithm of real per capita consumption in country $c$ relative to the cross-country geometric mean, $\bar{Y}$. There are an equal number of rich and poor countries (88) in these panels.

2. Panel C: The variable on the vertical axis, $\tilde{y}_{\eta q c}$, is the income-adjusted quality of consumption, defined as the residual of the linear regression of $y_{\eta q c}$, on $\log \left(Y_{c} / \bar{Y}\right)$ and other country characteristics listed in Table 9. The coefficients of this regression are in column 7 of Table 9.

3. All variables are multiplied by 100 . Heteroscedasticity-robust standard errors in parentheses. 
Figure 8. Food Budget Shares, Marginal Shares and Income Elasticities

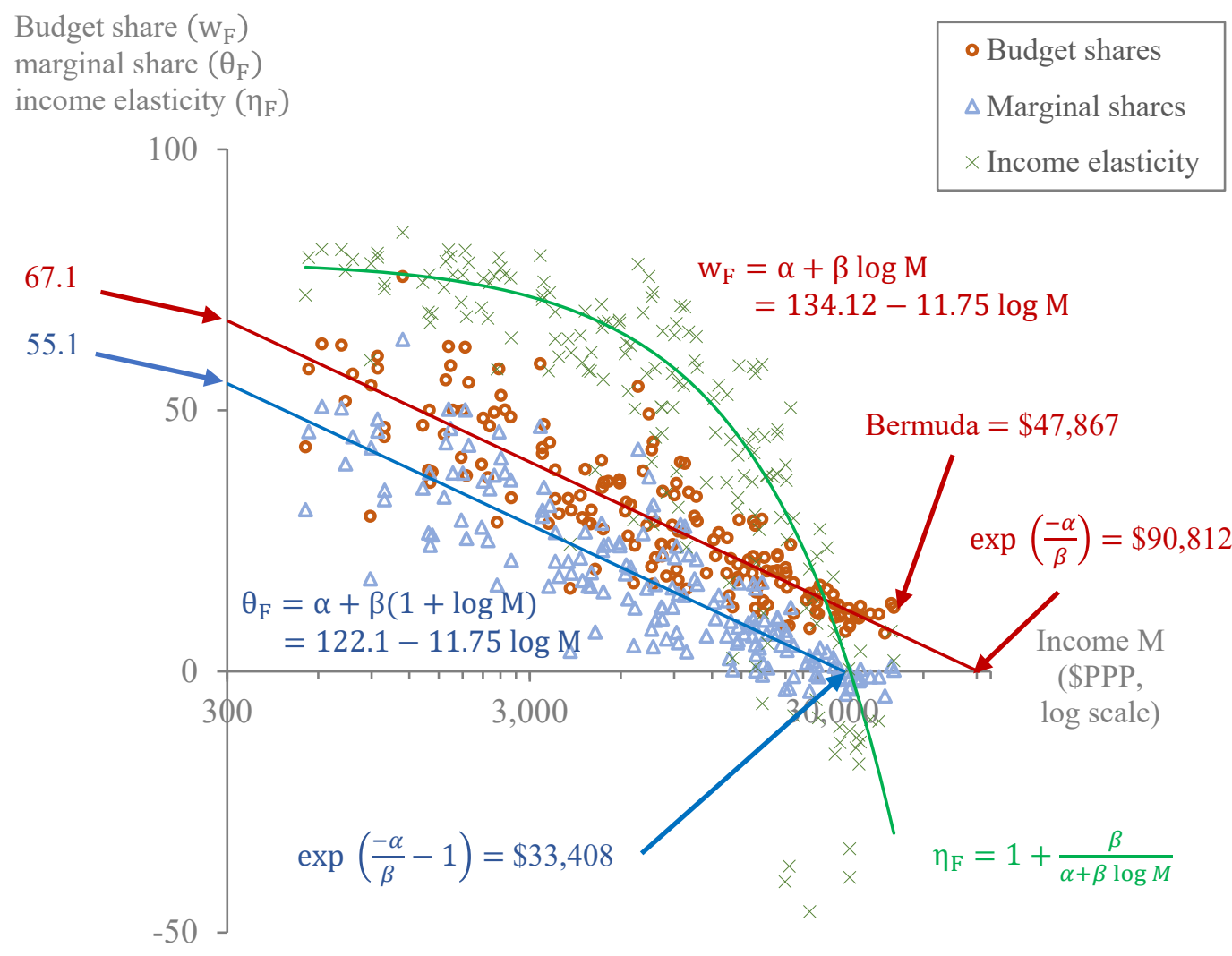

Notes:

1. The budget share of food $\left(w_{F}\right)$ is expenditure on the good as a proportion of income (total expenditure).

2. The marginal share $\left(\theta_{F}\right)$ is the increase in food expenditure following a $\$ 1$ increase in income. The marginal share of country $c$ is indicated by the blue triangle, computed as $\hat{\beta}_{F}+w_{F c}$, with $w_{F C}$ the observed budget share and $\hat{\beta}_{F}=$ -11.75 .

3. The income elasticity is $\eta_{F}=\theta_{F} / w_{F}$. The green cross is the elasticity for country $c$, computed as $1+\hat{\beta}_{F} / w_{F c}$.

4. Vertical axis values are multiplied by 100 . 
Figure 9. Per Capita Food Demand Projections

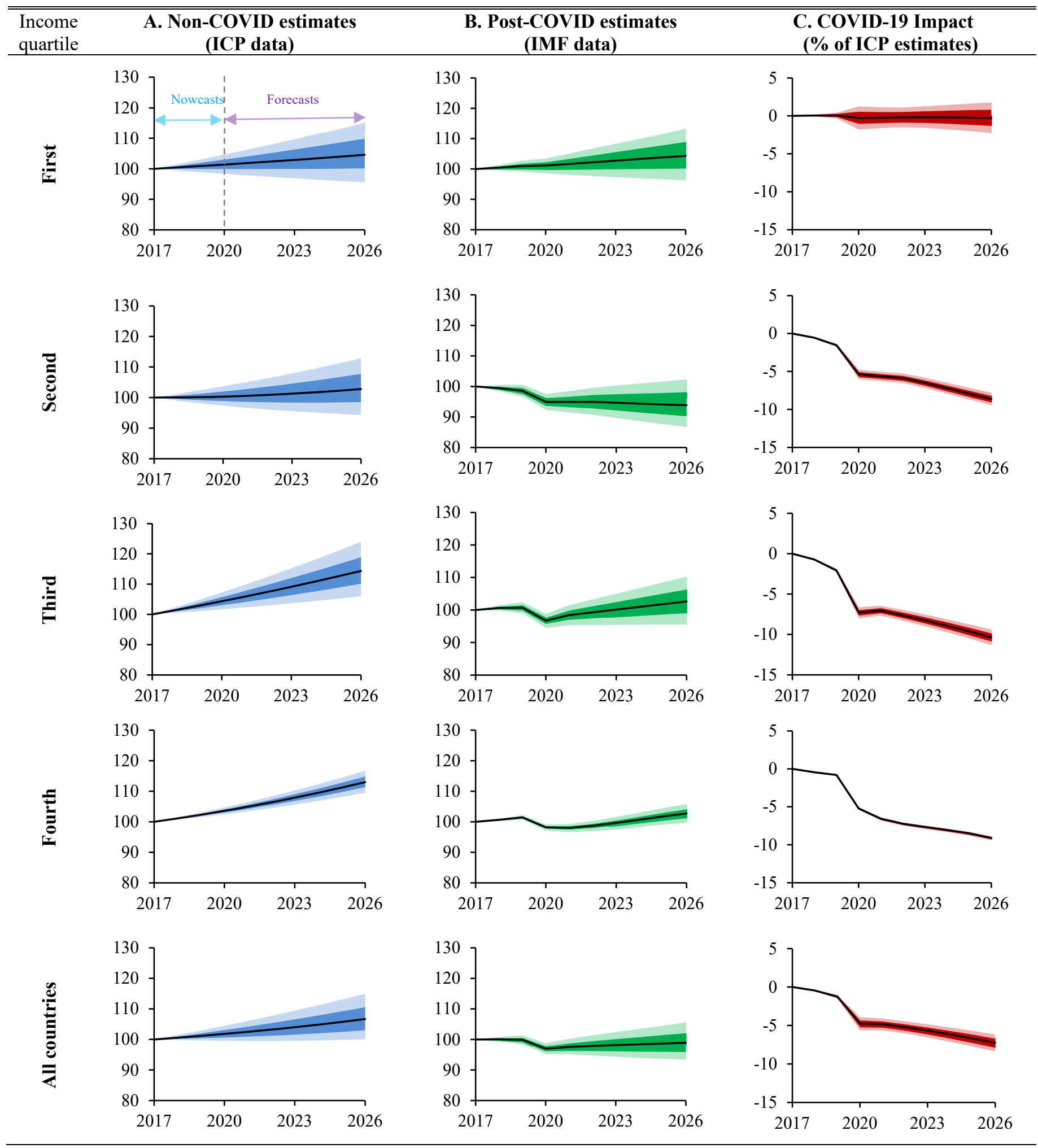

Note: In each panel, the solid line is the median while the dark (light) areas represent the $68 \%$ (95\%) confidence intervals of two sets of per capita food demand projections and their differences, based on 1,000 bootstrapped replications from estimates of the differential demand model. See Section 9 for details. 


\section{APPENDIX TABLE OF CONTENTS}

A1. Florida Model Derivations ......................................................

A2. Pairwise Differences Provide No Additional Information .......A-3

A3. Data and Estimation Procedures ............................................A-3

A4. Budget Share Predictions and the Elasticities .........................A-5

A5. Variables of Table 9 ..........................................................

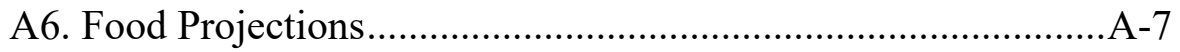

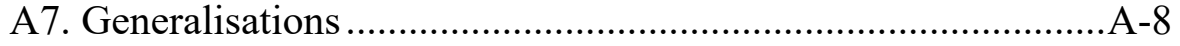

Appendix References ..............................................................

\section{A1. Florida Model Derivations}

Equation (4.1)

To derive Equation (4.1), start with the budget share, $w_{i}=\frac{p_{i} q_{i}}{M}$, and take its differential, $d w_{i}=w_{i}\left(d \log p_{i}+d \log q_{i}-d \log M\right)$. Using the decomposition of the change in money income into a price index and real income according to Equation (2.4), we have

$$
d w_{i}=w_{i}\left(d \log p_{i}-\sum_{j=1}^{n} w_{j} d \log p_{j}\right)+w_{i} d \log q_{i}-w_{i} d \log Q .
$$

Next, if we temporarily hold constant real income, the last term on the right of the above vanishes and from Equation (2.2) with $d \log Q=0, w_{i} d \log q_{i}=\sum_{j=1}^{n} \pi_{i j} d \log p_{j}$, where where $\pi_{i j}$ is a Slutsky coefficient. Consequently,

$$
\text { (A1.1) } d w_{i}=w_{i}\left(d \log p_{i}-\sum_{j=1}^{n} w_{j} d \log p_{j}\right)+\sum_{j=1}^{n} \pi_{i j} d \log p_{j}
$$

Under the simplifying assumption of preference independence, the Slutsky coefficients take the form $\pi_{i j}=\phi \theta_{i}\left(\delta_{i j}-\theta_{j}\right)$, where $\phi$ is the income flexibility, $\theta_{i}$ is the marginal share of $i$ and $\delta_{i j}$ is the Kronecker delta (for details, see the next section of this appendix). As a result,

$$
\sum_{j=1}^{n} \pi_{i j} d \log p_{j}=\sum_{j=1}^{n} \phi \theta_{i}\left(\delta_{i j}-\theta_{j}\right) d \log p_{j}=\phi \theta_{i}\left(d \log p_{j}-\sum_{j=1}^{n} \theta_{j} d \log p_{j}\right),
$$

and (A1.1) becomes

$$
\text { (A1.2) } \quad d w_{i}=w_{i}\left(d \log p_{i}-\sum_{j=1}^{n} w_{j} d \log p_{j}\right)+\phi \theta_{i}\left(d \log p_{j}-\sum_{j=1}^{n} \theta_{j} d \log p_{j}\right) .
$$

To apply (A1.2) to country $c$, write $\Delta_{i c}$ for the change in its budget share on account of the price effects and interpret the price differentials $d \log p_{i}$ as deviations from the world counterparts, $\log p_{i c}-\log \bar{p}_{i}=\log \frac{p_{i c}}{\bar{p}_{i}}$. This yields 
(A1.3) $\Delta_{i c}=\widetilde{w}_{i c}\left(\log \frac{p_{i c}}{\bar{p}_{i}}-\sum_{j=1}^{n} \widetilde{w}_{j c} \log \frac{p_{j c}}{\bar{p}_{j}}\right)+\phi \theta_{i c}\left(\log \frac{p_{i c}}{\bar{p}_{i}}-\sum_{j=1}^{n} \theta_{j c} \log \frac{p_{j c}}{\bar{p}_{j}}\right)$,

where $\widetilde{w}_{i c}$ is the budget share at world prices, as defined by Equation (4.2), and $\theta_{i c}$ is given by (4.3). Adding to the right-hand side of Equation (4.2) the price term (A1.3) and a disturbance term $\varepsilon_{i c}$ gives the observed budget share of $c$ :

$$
\begin{aligned}
w_{i c} & =\alpha_{i}+\beta_{i} \log Q_{c}+\Delta_{i c}+\varepsilon_{i c} \\
& =\alpha_{i}+\beta_{i} \log Q_{c}+\widetilde{w}_{i c}\left(\log \frac{p_{i c}}{\bar{p}_{i}}-\sum_{j=1}^{n} \widetilde{w}_{j c} \log \frac{p_{j c}}{\bar{p}_{j}}\right)+\phi \theta_{i}\left(\log \frac{p_{i c}}{\bar{p}_{i}}-\sum_{j=1}^{n} \theta_{j} \log \frac{p_{j c}}{\bar{p}_{j}}\right)+\varepsilon_{i c} .
\end{aligned}
$$

This is Equation (4.1).

\section{The Slutsky Coefficients}

Let $s_{i j}=\frac{\partial q_{i}}{\partial p_{j}}$ be the symmetric substitution effect of a change in the price of $j$ on the consumption of $i$, real income remaining unchanged. The corresponding Slutsky coefficient is $\pi_{i j}=\frac{p_{i} p_{j} s_{i j}}{M}$. Houthakker (1960) showed the substitution effect could be split into specific and general parts, $s_{i j}=\lambda u^{i j}-\frac{\lambda}{\partial \lambda / \partial M} \frac{\partial q_{i}}{\partial M} \frac{\partial q_{j}}{\partial M}$, where $u^{i j}$ is the $(i, j)^{t h}$ element of the inverse of the Hessian matrix of the utility function, that is, $u^{i j}=\left[\frac{\partial^{2} u}{\partial q_{i} \partial q_{j}}\right]^{-1}$, and $\lambda$ is the marginal utility of income. In the general case, the $(i, j)^{\text {th }}$ Slutsky coefficient can thus be expressed as

$$
\text { (A1.4) } \pi_{i j}=v_{i j}-\phi \theta_{i} \theta_{j} \text {, }
$$

where $v_{i j}=\frac{\lambda p_{i} p_{j} u^{i j}}{M}, \phi=\left(\frac{\partial \log \lambda}{\partial \log M}\right)^{-1}$ and $\theta_{i}=\frac{\partial\left(p_{i} q_{j}\right)}{\partial M}$ is the marginal share of $i$ (as before). Demand homogeneity (the absence of money illusion) implies $\sum_{j=1}^{n} \pi_{i j}=0, i=1, \cdots, n$, so that as $\sum_{i=1}^{n} \theta_{i}=1$,

$$
\text { (A1.5) } \sum_{j=1}^{n} v_{i j}=\phi \theta_{i}, i=1, \cdots, n \text {. }
$$

When tastes exhibit preference independence, the utility function takes the form $u\left(q_{1}, \cdots, q_{n}\right)=\sum_{i=1}^{n} u_{i}\left(q_{i}\right)$, where $u_{i}(\cdot)$ is the $i^{t h}$ a sub-utility function that depends only on the consumption of good $i$. In this case, the marginal utility of good $i$ is unaffected by changes in the consumption of all others, the Hessian is diagonal and $u^{i j}=v_{i j}=0, i \neq j$. Under preference independence, constraint (A1.5) becomes $v_{i i}=\phi \theta_{i}$ and (A1.4) implies that $\pi_{i i}=$ $\phi \theta_{i}\left(1-\theta_{i}\right), i=1, \cdots, n$, and $\pi_{i j}=-\phi \theta_{i} \theta_{j}, i \neq j$. 


\section{A2. Pairwise Differences Provide No Additional Information}

Let $\boldsymbol{x}=\left[x_{i}\right]=\left[\begin{array}{lll}x_{1} & \ldots & x_{n}\end{array}\right]^{\prime}$ be a column vector of $n$ elements with mean $\bar{x}=$ $\frac{1}{n} \sum_{i=1}^{n} x_{i}$ and variance $\sigma^{2}=\frac{1}{n} \sum_{i=1}^{n}\left(x_{i}-\bar{x}\right)^{2}$. If $\iota$ is a column vector of unit elements, all the $n^{2}$ pairwise differences among the elements of $\boldsymbol{x}$ are given by the $n \times n$ matrix

$$
\left[x_{i}-x_{j}\right]=\left[\begin{array}{c}
x_{1} \\
\vdots \\
x_{n}
\end{array}\right]\left[\begin{array}{lll}
1 & \ldots & 1
\end{array}\right]-\left[\begin{array}{c}
1 \\
\vdots \\
1
\end{array}\right]\left[\begin{array}{lll}
x_{1} & \ldots & x_{n}
\end{array}\right]=\boldsymbol{x} \boldsymbol{\iota}^{\prime}-\boldsymbol{\iota} \boldsymbol{x}^{\prime}=\boldsymbol{X} \text { (say). }
$$

The row means of $\boldsymbol{X}$ are

$$
\overline{\bar{x}}=\frac{1}{n} \boldsymbol{X} \iota=\frac{1}{n}\left(\boldsymbol{x} \boldsymbol{\iota}^{\prime}-\iota \boldsymbol{x}^{\prime}\right) \boldsymbol{\iota}=\boldsymbol{x}-\boldsymbol{\iota} \bar{x} .
$$

which is the deviation of each element of $\boldsymbol{x}$ from the mean. The matrix of deviations of the elements of $\boldsymbol{X}$ from the corresponding mean is $\boldsymbol{X}-\overline{\overline{\boldsymbol{x}} \boldsymbol{\iota}^{\prime}}$ and the moment matrix is (Clements and Izan, 2012):

$$
\left(\boldsymbol{X}-\overline{\bar{x}} \iota^{\prime}\right)^{\prime}\left(\boldsymbol{X}-\overline{\overline{\boldsymbol{x}}} \boldsymbol{\iota}^{\prime}\right)=n \sigma^{2} \boldsymbol{\iota}^{\prime} .
$$

Also, the mean sum of the squared elements of $\boldsymbol{X}$ is

$$
\frac{1}{n^{2}} \sum_{i=1}^{n} \sum_{j=1}^{n}\left(x_{i}-x_{j}\right)^{2}=2 \sigma^{2} .
$$

The matrix of pairs $\boldsymbol{X}$ is just a transform of the original vector $\boldsymbol{x}$ and so reflects the same basic information, viz., the mean and dispersion. The obvious conclusion is that nothing is to be gained with pairwise differences.

\section{A3. Data and Estimation Procedures}

Aggregating ICP

Table A3.1 shows how the ICP data were aggregated to $n=9$ categories of goods and services and their composition.

\section{The Models}

The differential demand model is Equation (5.5), which is

$$
\bar{w}_{i c}\left(\Delta \log q_{i c}-\Delta \log Q_{c}\right)=\alpha_{i}+\beta_{i} \Delta \log Q_{c}+\sum_{j=1}^{n} \pi_{i j} \log p_{j c}+\varepsilon_{i c}, i=1, \cdots, n .
$$

Here, $\pi_{i j}=v_{i j}-\phi \theta_{i} \theta_{j}$ is the Slutsky coefficient, with $\sum_{j=1}^{n} v_{i j}=\phi \theta_{i}$; and $\theta_{i c}=\bar{w}_{i c}+\beta_{i}$ is the marginal share.

Under homogeneity, $\sum_{j=1}^{n} \pi_{i j}=0$. Under symmetry (with homogeneity imposed), $\pi_{i j}=\pi_{j i}, i \neq j$. As discussed above, under preference independence, $v_{i j}=0$ for $i \neq j$, so $\sum_{j=1}^{n} v_{i j}=\phi \theta_{i}$ becomes $v_{i i}=\phi \theta_{i}$. Then, with $\delta_{i j}$ the Kronecker delta, 
(A3.2) $\pi_{i j}=\phi \theta_{i}\left(\delta_{i j}-\theta_{j}\right)=\left\{\begin{array}{c}-\phi\left(w_{i}+\beta_{i}\right)\left(w_{j}+\beta_{j}\right) \text { for } i \neq j \\ \phi\left(w_{i}+\beta_{i}\right)\left(1-\left[w_{j}+\beta_{j}\right]\right) \text { for } i=j .\end{array}\right.$

We shall treat $w_{i}$ here as constants and define $w_{i}=\frac{1}{176} \sum_{c=1}^{176} \bar{w}_{i c}=\frac{1}{176} \sum_{c=1}^{176} \frac{1}{2}\left(w_{i c}+w_{i}^{*}\right)=$ $w_{i}^{*}$. For estimation, we drop the $9^{\text {th }}$ equation and use $\beta_{9}=-\sum_{i=1}^{8} \beta_{i}$ and $\alpha_{9}=-\sum_{i=1}^{8} \alpha_{i}$. For $i=1, \ldots, 8$, the parameters to be estimated are $\alpha_{i}, \beta_{i}$ and $\phi$. This gives a total of $8 \times 2+1=$ 17 free parameters. Under no price effects, we have $\pi_{i j}=0 \forall i, j$.

Eviews Syntax

Table A3.2 gives the coefficients under preference independence in terms of the syntax implemented in the statistical software Eviews ( $11^{\text {th }}$ edition). The implementation in Eviews is as follows:

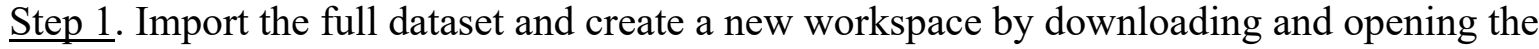
following file in Eviews:

https://drive.google.com/file/d/1pGRmYsu1B38ESCxCPAmPuWYIzqtyMq9n/view?us $\mathrm{p}=$ sharing

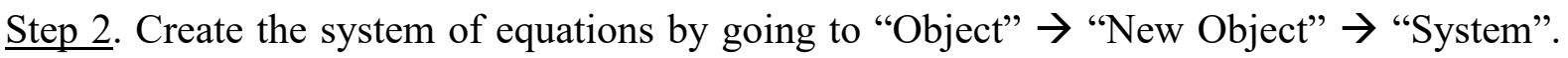
Name this system object "PI".

$\underline{\text { Step 3 }}$. Write the model with Eviews syntax by using the "system specification" argument. For example, substituting $-\sum_{i=1}^{8} \beta_{i}$ for $\beta_{9}$, the preference-independence equation for "Food" is (with the own-price term emboldened):

fooddrink_cons $=c(11)+c(21) *$ income $+c(10) *(0.29+c(21)) *(1-$

$(0.29+c(21))) *$ fooddrink_price $-c(10) *(0.29+c(21)) *(0.04+c(22)) *$ clothing_price $c(10) *(0.29+c(21)) *(0.16+c(23)) *$ housing price -

$c(10) *(0.29+c(21)) *(0.04+c(24)) *$ furnishings_price -

$c(10) *(0.29+c(21)) *(0.08+c(25)) *$ health_price -

$c(10) *(0.29+c(21)) *(0.07+c(26)) *$ education_price $c(10) *(0.29+c(21)) *(0.05+c(27)) *$ restaurants_price -

$c(10) *(0.29+c(21)) *(0.05+c(28)) *$ recreation price $-c(10) *(0.29+c(21)) *(0.22-$ $(c(21)+c(22)+c(23)+c(24)+c(25)+c(26)+c(27)+c(28))) *$ miscellaneous_price

The 8-equation systems for all specifications are laid out in full in Table A3.3.

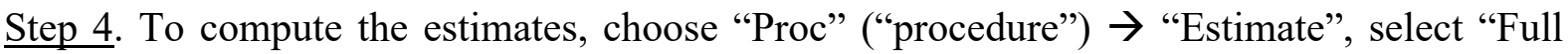
Information Maximum Likelihood" for "Estimation method". This option also allows us 
to compute a log likelihood value and facilitate hypothesis testing, as described in Table 5 of the main text.

Step 5. To map the coefficients estimated by Eviews into the Slutsky coefficients, use expression (also given above) $\pi_{i j}=\phi \theta_{i}\left(\delta_{i j}-\theta_{j}\right)$. As $\pi_{i j}=\pi_{j i}$, we need only the upper triangle of the $9 \times 9$ matrix $\left[\pi_{i j}\right]$. These coefficients can be computed in Eviews via the hypothesis-testing function. Choose "View" $\rightarrow$ "Coefficient Diagnostics" $\rightarrow$ "Wald Coefficient Tests", and set the expressions to zero. Thus, for example, these expression for 9 preference-independence Slutsky coefficients of the "Food" equation are:

$$
\begin{aligned}
& c(10) *(0.29+c(21)) *(1-(0.29+c(21)))=0 \\
& -c(10) *(0.29+c(21)) *(0.04+c(22))=0 \\
& -c(10) *(0.29+c(21)) *(0.16+c(23))=0 \\
& -c(10) *(0.29+c(21)) *(0.04+c(24))=0 \\
& -c(10) *(0.29+c(21)) *(0.08+c(25))=0 \\
& -c(10) *(0.29+c(21)) *(0.07+c(26))=0 \\
& -c(10) *(0.29+c(21)) *(0.05+c(27))=0 \\
& -c(10) *(0.29+c(21)) *(0.05+c(28))=0 \\
& -c(10) *(0.29+c(21)) *(0.22-(c(21)+c(22)+c(23)+c(24)+c(25)+c(26)+c(27)+c(28)))=0
\end{aligned}
$$

The full set of expressions are contained in Table A3.4.

Step 6. The coefficients directly estimated by Eviews are given in Table A3.5, while the derived Slutsky coefficients are in Table A3.6. These are the same as in panel C of Table 4.

\section{A4. Budget Share Predictions and Elasticities}

The demand equation for good $i$ in country $c$ is

$$
\bar{w}_{i c}\left(\Delta \log q_{i c}-\Delta \log Q_{c}\right)=\alpha_{i}+\beta_{i} \Delta \log Q_{c}+\sum_{j=1}^{n} \pi_{i j} \Delta \log p_{j c}+\varepsilon_{i c}, i=1, \cdots, n .
$$

Since the budget share is $w_{i}=\frac{p_{i} q_{i}}{M}$, its infinitesimal change is

$$
\begin{aligned}
& d w_{i}=d\left(\frac{p_{i} q_{i}}{M}\right)=w_{i} d\left(\log p_{i}\right)+w_{i} d\left(\log q_{i}\right)-w_{i} d(\log M)=w_{i}\left\{d\left(\log p_{i}\right)-\right. \\
& d(\log P)\}+w_{i}\left\{d\left(\log q_{i}\right)-d(\log Q)\right\} .
\end{aligned}
$$

Here, $d \log P=\sum_{i=1}^{n} w_{i} d \log p_{i}$ and $d \log Q=\sum_{i=1}^{n} w_{i} d \log q_{i}$, which satisfy $d \log P+$ $d \log Q=d \log M$. Thus, the difference between the budget share in $c$ and that of the world is $(\mathrm{A} 4.2) \quad w_{i c}-w_{i}^{*}=\bar{w}_{i c}\left(\Delta \log p_{i c}-\Delta \log P_{c}\right)+\bar{w}_{i c}\left(\Delta \log q_{i c}-\Delta \log Q_{c}\right)+O_{3}$, where $\Delta \log P_{c}=\sum_{i=1}^{n} w_{i c} \Delta \log p_{i c}$ and $\Delta \log Q_{c}=\sum_{i=1}^{n} w_{i c} \Delta \log q_{i c}$ are Divisia price and volume indices; and $\mathrm{O}_{3}$ is a third-order remainder term in price- and quantity log-changes. 
The predicted value of the variable on the left of (A4.1) is $\bar{w}_{i c}\left(\Delta \log q_{i c}-\Delta \log Q_{c}\right)-$ $\hat{\varepsilon}_{i c}$, where $\hat{\varepsilon}_{i c}=\bar{w}_{i c}\left(\Delta \log q_{i c}-\Delta \log Q_{c}\right)-\hat{\beta}_{i} \Delta \log Q_{c}-\sum_{j=1}^{n} \hat{\pi}_{i j} \Delta \log p_{j c}$ denotes the $c^{t h}$ residual of the $i^{\text {th }}$ equation. Replacing $\bar{w}_{i c}\left(\Delta \log q_{i c}-\Delta \log Q_{c}\right)$ in (A4.2) with $\bar{w}_{i c}\left(\Delta \log q_{i c}-\Delta \log Q_{c}\right)-\hat{\varepsilon}_{i c}$, the difference between the predicted share $\left(\widehat{w}_{i c}\right)$ and $w_{i}^{*}$ is

$$
\widehat{w}_{i c}-w_{i}^{*}=\bar{w}_{i c}\left(\Delta \log p_{i c}-\Delta \log P_{c}\right)+\bar{w}_{i t}\left(\Delta \log q_{i c}-\Delta \log Q_{c}\right)-\hat{\varepsilon}_{i c}+O_{3} .
$$

Finally, subtracting (A4.2) from (A4.3) gives

$$
\text { (A4.4) } \widehat{w}_{i c}=w_{i c}-\hat{\varepsilon}_{i c}
$$

for the prediction of $w_{i c}$.

Consider the implications for the elasticities. The income elasticity of $i, \frac{\theta_{i}}{w_{i}}$, where $\theta_{i}$ is the marginal share. We could evaluate this using the budget share averaged over $c$ and the world, $\frac{1}{2}\left(w_{i c}+w_{i}^{*}\right)$, which would give

$$
\frac{\theta_{i}}{\frac{1}{2}\left(w_{i c}+w_{i}^{*}\right)}=\left\{\frac{1}{2}\left(\frac{w_{i c}}{\theta_{i}}+\frac{w_{i}^{*}}{\theta_{i}}\right)\right\}^{-1}=\left\{\frac{1}{2}\left(\left[\frac{\theta_{i}}{w_{i c}}\right]^{-1}+\left[\frac{\theta_{i}}{w_{i}^{*}}\right]^{-1}\right)\right\}^{-1} .
$$

The third term in the above is the harmonic mean of $\frac{\theta_{i}}{w_{i c}}$ and $\frac{\theta_{i}}{w_{i}^{*}}$, the income elasticities for $c$ and that of the world. This measure pulls the elasticities for all countries towards that of the world, giving the tendency for equalisation across countries. As such a tendency would smooth out much of the interesting diversity across countries, it is preferable to instead use $\frac{\theta_{i}}{w_{i c}}$ and to exclude the noise, replace the observed share with the predicted one from (A4.4), $\frac{\theta_{i c}}{\widehat{w}_{i c}}=\frac{\theta_{i c}}{w_{i c}-\widehat{\varepsilon}_{i c}}$.

When demand Equation (A4.1) is used, the marginal share is equal to $\beta_{i}$ plus the budget share. Using the predicted share as above, the income elasticity is

$$
\frac{\theta_{i c}}{\widehat{w}_{i c}}=\frac{\beta_{i}+\widehat{w}_{i c}}{\widehat{w}_{i c}}=1+\frac{\beta_{i}}{\widehat{w}_{i c}} \text {. }
$$

Similarly, the Slutsky price elasticities can be evaluated with the predicted shares as $\frac{\pi_{i j}}{\widehat{w}_{i c}}$. Tables A4.1 and A4.2 give the income and own-price elasticities for each country.

\section{A5. Variables of Table 9}

Table 9 deals with the determinants of quality. The following gives the detailed definitions of the determining variables of that table:

1. "Income" is defined as $\log \left(Y_{c} / \bar{Y}\right)$, the logarithm of real per capita consumption in country $c$ relative to the cross-country geometric mean income, $\bar{Y}$. 


\section{A-7}

2. "Happiness" is measured by a "life-evaluation" index computed by the World Happiness Report (2021) based on answers to the main life evaluation question asked in the Gallup World Poll: It asks respondents to think of a ladder, with the best possible life for them being a 10 , and the worst possible life being a 0 . The rankings are from nationally representative samples, for the years 2018-2020. We convert this variable to 0 to 100 scale by multiplying it with 10 .

3. "Income inequality" is measured by the Gini index, which ranges from 0 to 100.

4. "Human capital" is measured by the Human Capital Index, which calculates the contributions of health and education to optimal worker productivity. The final index score ranges from 0 to 1 and measures the productivity as a future worker of a child born today relative to the benchmark of full health and complete education. We convert this variable to 0 to 100 scale by multiplying by 100 .

5. "\% pop. with internet" stands for the share of people who have used the Internet (from any location) in the last 3 months. The Internet can be used via a computer, mobile phone, personal digital assistant, games machine, digital TV etc.

6. "Urbanisation" is measured by the share of people living in urban areas as defined by national statistical offices.

Items 3 to 6 above refer to 2017 and are from is the World Development Indicators database (World Bank, 2021). Item 2 (happiness) comes from the World Happiness Report (2021) and refers to the period 2018 - 2020. The sample size for the regressions in Table 9 is 130 , instead of 176 , due to missing data.

\section{A6. Food Projections}

There are 160 countries common to the ICP (World Bank, 2020), IMF (2021) and UN (2019) databases; these countries are listed in Table A6.1. The annualised growth rates of income and prices between the 2011 and 2017 rounds of ICP are also given in this table. Looking at the quartile averages, income growth is lowest in the richest countries and higher for the second- and third-quartile countries, indicating a modest tendency for growth convergence. Food prices exhibit the same pattern, that is, on average, the cost of food grows slowest in the first-quartile countries, higher in the other quartiles.

As the World Economic Outlook (IMF, 2021) database covers the period up to 2026 while ICP food demand data is only available up to 2017, our approach essentially produces "nowcasts" from 2017 to 2020 and forecasts from 2021 to 2026. Panel A of Figure A6.1 presents the projections of aggregated food consumption (not per capita) for each income 
quartile during this period. This figure shows that the share of middle-income countries in global food demand is greater than that of the richest and poorest countries (due to the most populous countries being in the middle-income countries). Panel B of the figure gives the

corresponding per capita demands, $\frac{\sum_{c \in S_{g} N_{c} q_{F, c}}}{\sum_{c \in S_{g} N_{c}}}=\sum_{c \in S_{g}} \frac{N_{c}}{\sum_{c \in S_{g} N_{c}}} q_{F, c}$, which are populationshare weighted averages of per capita consumption in each member country $\left(N_{c}\right.$ is the population of country $c$; $q_{F, c}$ is per capita food consumption in $c$; and $\boldsymbol{S}_{g}$ is the set of countries in income quartile $g$ ). In both scenarios, the fastest growth in most years is observed for the third quartile, followed by the fourth, second and first. Though aggregated demand grows fastest for the poorest group, due to their higher population growth, their per capita demand still lags behind the third quartile (see Table A6.2). The red shaded regions of panel B of Figure A6.1 represent the differences between the two sets of projections, which we interpret as approximating the COVID-19 effect on food. As can be seen, poorer economies are harder hit by the pandemic.

\section{A7. Generalisations}

The estimates of Table 4 refer to all 176 countries. Rather than combining all countries together, this appendix explores the implications of generalisations that classify countries into groups.

\section{Quartile Intercepts}

We divide countries into $K$ groups, to be denoted by the sets $\boldsymbol{G}^{1}, \cdots, \boldsymbol{G}^{K}$, with group $k$ containing $C^{k}$ countries, $k=1, \cdots, K$. For each group, the mean quantities, prices and budget shares are (logarithms of geometric means for quantities and prices)

$$
\log q_{i}^{k}=\frac{1}{c^{k}} \sum_{c \in G^{k}} \log q_{i c}, \quad \log p_{i}^{k}=\frac{1}{c^{k}} \sum_{c \in G^{k}} \log p_{i c}, w_{i}^{k}=\frac{1}{c^{k}} \sum_{c \in G^{k}} w_{i c} .
$$

We now interpret the variables of demand Equation (5.1) for country $c$ as that country's differences from group means:

$$
\Delta \log q_{i c}=\log q_{i c}-\log q_{i}^{k}, \quad \Delta \log p_{i c}=\log p_{i c}-\log p_{i}^{k}, c \in \boldsymbol{G}^{k} .
$$

The corresponding income difference is

$$
\Delta \log Q_{c}=\sum_{i=1}^{n} \bar{w}_{i c} \Delta \log q_{i c}, \text { with } \bar{w}_{i c}=\frac{1}{2}\left(w_{i c}+w_{i}^{k}\right) .
$$

This is the difference of $c$ 's income from that of the group, and is defined as a weighted average of the differences in the $n$ elements in the basket, where these differences are relative to the group means. The weights are budget shares, defined as averages of those of $c$ and the group, which is consistent with the relative-to-the-group treatment of quantity changes. 
Thus, the demand for $i$ becomes

$$
\bar{w}_{i c} \Delta \log q_{i c}=\theta_{i} \Delta \log Q_{c}+\sum_{j=1}^{n} \pi_{i j} \Delta \log p_{j c}+\varepsilon_{i c} .
$$

According to demand homogeneity $\sum_{j=1}^{n} \pi_{i j}=0$, which means that the price term can be expressed as

$$
\begin{aligned}
& \sum_{j=1}^{n} \pi_{i j} \Delta \log p_{i c} \\
& =\sum_{j=1}^{n-1} \pi_{i j}\left\{\left(\log p_{j c}-\log p_{j}^{k}\right)-\left(\log p_{n c}-\log p_{n}^{k}\right)\right\} \\
& =\sum_{j=1}^{n-1} \pi_{i j}\left\{\log p_{j c}-\log p_{n c}-\left(\log p_{j}^{k}-\log p_{n}^{k}\right)\right\} .
\end{aligned}
$$

As the relative price of $\operatorname{good} j$ for group $k, \log p_{j}^{k}-\log p_{n}^{k}$, is a constant for members, the term $\alpha_{i}^{k}=-\sum_{j=1}^{n-1} \pi_{i j} \log \left(\frac{p_{j}^{k}}{p_{n}^{k}}\right)$ acts as an intercept in the demand equation. Accordingly, the system becomes

$$
\bar{w}_{i c} \Delta \log q_{i c}=\alpha_{i}^{k}+\theta_{i} \Delta \log Q_{c}+\sum_{j=1}^{n-1} \pi_{i j} \log \left(\frac{p_{j c}}{p_{n c}}\right)+\varepsilon_{i c}, i=1, \cdots, n ; c \in \boldsymbol{G}^{k} ; k=1, \cdots, K,
$$

with $\sum_{i=1}^{n} \alpha_{i}^{k}=0$. Using Working's (1942) model for the marginal shares, we have

$$
\begin{aligned}
& \bar{w}_{i c}\left(\Delta \log q_{i c}-\Delta \log Q_{c}\right)=\alpha_{i}^{k}+\beta_{i} \Delta \log Q_{c}+\sum_{j=1}^{n-1} \pi_{i j} \log \left(\frac{p_{j c}}{p_{n c}}\right)+\varepsilon_{i c}, \\
& i=1, \cdots, n ; c \in \boldsymbol{G}^{k} ; k=1, \cdots, K .
\end{aligned}
$$

To implement model (A7.1), we use income quartiles, so $K=4$. Table A7.1 contains the results. We shall focus on the symmetry-constrained estimates of panel B and compare these with Table 4, where all countries have the same intercepts. This reveals (i) except for one case, the own-Slutsky coefficients do not change appreciably; (ii) the cross-Slutsky coefficients do change, but the changes are unlikely to be significant; (iii) the income coefficients mostly move in the direction of zero, so the income elasticities would now be closer to unity; and (iv) only two of the income coefficients are now significant, those of food and miscellaneous.

The most likely explanation for the above changes is that a large part of the differences in income across countries is the between-quartile component, causing the quartile intercepts to be correlated with income. The quartile intercepts thus "absorb" much of the income differences, diminishing the role of income, as indicated by the smaller and less significant income coefficients.

\section{Quartile Income Slopes}

We modify the above approach by allowing income slopes to vary by income quartile, while the other coefficients remain the same across all countries. The results are contained in Table A7.2. It can be seen from panel B that (i) among the 36 income coefficients, there does not seem to be any particular pattern across countries, and only about 15 percent of the 
coefficients are significant; (ii) the own-Slutsky coefficients are quite similar to those of Table 4; and (iii) most of the cross-price Slutsky coefficients that are large and significant in Table 4 remain large and significant.

\section{Quartile Intercepts and Slopes}

We now allow the intercepts, income slopes and the Slutsky coefficients to all vary by income quartile. The system for each quartile can now be estimated by separately from the others and the results are in Tables A7.3 - A7.6. Again, focusing on the symmetry-constrained estimates, it can be seen that many of the income coefficients are insignificant, as before. Additionally, the standard errors of the Slutsky coefficients are now substantially higher than those of Table 4, and one of the own-price coefficients is positive (but insignificant). This reflects the smaller number of observations available to estimate the quartile-specific effects.

\section{Rich and Poor Countries}

Finally, we use two groups of countries, the rich (those with incomes above the median) and the poor (below the median) with all coefficients differing across groups. The results are in Tables A7.7 - A7.8. There are the same issues as before with small income coefficients and high standard errors of the Slutsky coefficients.

\section{Summary and Conclusion}

Figure A7.1 compares the above estimates with those of the pooled baseline model for all countries (those of panel B, Table 4). As there is a reasonable degree of stability of the coefficients, it is preferable to concentrate of the results of Table 4. A further attraction of the baseline results is that the full role of income is reflected in the coefficients of the income variable, rather than the quartile-specific intercepts.

\section{Appendix References}

Clements, K. W., and H. Y. Izan (2012). "The Pay Parity Matrix: A Tool for Analysing the Structure of Pay." Applied Economics 44: 4515-25.

Houthakker, H. S. (1960). "Additive Preferences." Econometrica 28: 244-57.

International Monetary Fund (2021). World Economic Outlook. Accessed on 3rd September 2021. Available at: https://www.imf.org/en/Publications/WEO/weodatabase/2021/April/

United Nations (2019). World Population Prospects: Population Division. Accessed on $3^{\text {rd }}$ September 2021. Available at: https://population.un.org/wpp/

World Bank (2013). Measuring the Real Size of the World Economy. World Bank: Washington, D. C. Available at: https://doi.org/10.1596/978-0-8213-9728-2.

World Bank (2020). International Comparisons Program. Accessed on $10^{\text {th }}$ December 2020. Available at: https://www.worldbank.org/en/programs/icp

World Bank (2021). "World Development Indicators." Accessed on $11^{\text {th }}$ July 2021. Available at: https://datatopics.worldbank.org/world-development-indicators/

World Happiness Report (2021). Accessed on $11^{\text {th }}$ July 2021. Available at: https://worldhappiness.report/ 
A-11

Table A3.1. ICP Categories of Household Expenditure

\begin{tabular}{|c|c|c|}
\hline $\begin{array}{c}\text { Category } \\
\text { (1) }\end{array}$ & $\begin{array}{l}\text { Commodity } \\
\text { group } \\
(2)\end{array}$ & $\begin{array}{l}\text { Definition } \\
\text { (3) }\end{array}$ \\
\hline $\begin{array}{l}\text { 1. Food and non- } \\
\text { alcoholic } \\
\text { beverages }\end{array}$ & 1. Food & $\begin{array}{l}\text { Food products and non-alcoholic beverages purchased for consumption at home (excludes } \\
\text { food products and non-alcoholic beverages sold for immediate consumption away from } \\
\text { home by hotels, restaurants, cafés, bars, kiosks, street vendors, automatic vending } \\
\text { machines, etc.; cooked dishes prepared by restaurants for consumption off their premises; } \\
\text { cooked dishes prepared by catering contractors whether collected by the customer or } \\
\text { delivered to the customer's home; and products sold specifically as pet foods). }\end{array}$ \\
\hline $\begin{array}{l}\text { 2. Alcoholic } \\
\text { beverages, } \\
\text { tobacco, and } \\
\text { narcotics }\end{array}$ & 1. Food & $\begin{array}{l}\text { Alcoholic beverages purchased for consumption at home (includes low or non-alcoholic } \\
\text { beverages that are generally alcoholic such as non-alcoholic beer, and excludes alcoholic } \\
\text { beverages sold for immediate consumption away from the home by hotels, restaurants, } \\
\text { cafés, bars, kiosks, street vendors, automatic vending machines, etc.) and household } \\
\text { expenditure on tobacco (covers all purchases of tobacco, including purchases of tobacco } \\
\text { in cafés, bars, restaurants, service stations, etc.). }\end{array}$ \\
\hline $\begin{array}{l}\text { 3. Clothing and } \\
\text { footwear }\end{array}$ & 2. Clothing & $\begin{array}{l}\text { Clothing materials; garments for men, women, children, and infants; other articles of clothing } \\
\text { and clothing accessories; cleaning, repair, and hire of clothing; all footwear for men, } \\
\text { women, children, and infants; and repair and hire of footwear. }\end{array}$ \\
\hline $\begin{array}{l}\text { 4. Housing, water, } \\
\text { electricity, gas } \\
\text { and other fuels }\end{array}$ & 3. Housing & $\begin{array}{l}\text { Actual and imputed rentals for housing; maintenance and repair of the dwelling; water supply } \\
\text { and services related to the dwelling; and electricity and gas and other fuels-plus } \\
\text { expenditure of non-profit institutions serving households (NPISHs) on housing plus } \\
\text { general government expenditure on housing services provided to individuals. }\end{array}$ \\
\hline $\begin{array}{l}\text { 5. Furnishings, } \\
\text { household } \\
\text { equipment and } \\
\text { maintenance }\end{array}$ & 4. Furnishings & $\begin{array}{l}\text { Furniture and furnishings; carpets and other floor coverings; household textiles; household } \\
\text { appliances; glassware, tableware, and household utensils; tools and equipment for house } \\
\text { and garden; and goods and services for routine household maintenance. }\end{array}$ \\
\hline 6. Health & 5. Health & $\begin{array}{l}\text { Pharmaceuticals; medical products, appliances, and equipment; outpatient services; and } \\
\text { hospital services-plus expenditure of NPISHs on health plus general government } \\
\text { expenditure on health benefits and reimbursements and the production of health services. }\end{array}$ \\
\hline 7. Education & 6. Education & $\begin{array}{l}\text { Pre-primary, primary, secondary, postsecondary, and tertiary education-plus expenditure of } \\
\text { NPISHs on education plus general government expenditure on educational benefits and } \\
\text { reimbursements and the production of educational services. }\end{array}$ \\
\hline $\begin{array}{l}\text { 8. Restaurants and } \\
\text { hotels }\end{array}$ & 7. Restaurants & $\begin{array}{l}\text { Food products and beverages sold for immediate consumption away from the home by hotels, } \\
\text { restaurants, cafés, bars, kiosks, street vendors, automatic vending machines, etc. } \\
\text { (includes cooked dishes prepared by restaurants for consumption off their premises; } \\
\text { cooked dishes prepared by catering contractors, whether collected by the customer or } \\
\text { delivered to the customer's home); and household expenditure on accommodation } \\
\text { services provided by hotels and similar establishments. }\end{array}$ \\
\hline $\begin{array}{l}\text { 9. Recreation and } \\
\text { culture }\end{array}$ & 8. Recreation & $\begin{array}{l}\text { Audiovisual, photographic, and information processing equipment; other major durables for } \\
\text { recreation and culture; other recreational items and equipment; gardens and pets; } \\
\text { recreational and cultural services; newspapers, books, and stationery; and package } \\
\text { holidays-plus expenditure of NPISHs on recreation and culture plus general government } \\
\text { expenditure on recreation and culture. }\end{array}$ \\
\hline 10. Transport & 9. Miscellaneous & Purchase of vehicles, operation of personal transport equipment, and transport services. \\
\hline 11. Communication & 9. Miscellaneous & Postal services, telephone and telefax equipment, and telephone and telefax services. \\
\hline $\begin{array}{l}\text { 12. Miscellaneous } \\
\text { goods and } \\
\text { services }\end{array}$ & 9. Miscellaneous & $\begin{array}{l}\text { Personal care, personal effects, social protection, insurance, and financial and other services- } \\
\text { plus expenditure by NPISHs on social protection and other services plus general } \\
\text { government expenditure on social protection. }\end{array}$ \\
\hline
\end{tabular}

1. Columns 1 and 3: The titles and detailed definitions of the 12 household consumption expenditure categories used by the International Comparison Program (World Bank, 2013).

2. Column 2: The 9 commodity groups used in this paper. 
A-12

Table A3.2. Preference Independence, Eviews Notation

\begin{tabular}{clccc}
\hline \hline Commodity & $\begin{array}{c}\text { Average } \\
\text { budget } \\
\text { shares } \\
w_{i}\end{array}$ & $\begin{array}{c}\text { Intercepts } \\
\alpha_{i}\end{array}$ & $\begin{array}{c}\text { Income } \\
\text { coefficients } \\
\beta_{i}\end{array}$ \\
\hline 1. & Food & 0.29 & $\mathrm{c}(11)$ & $\mathrm{c}(21)$ \\
2. & Clothing & 0.04 & $\mathrm{c}(12)$ & $\mathrm{c}(22)$ \\
3. Housing & 0.16 & $\mathrm{c}(13)$ & $\mathrm{c}(23)$ \\
4. & Furnishings & 0.04 & $\mathrm{c}(14)$ & $\mathrm{c}(24)$ \\
5. Health & 0.08 & $\mathrm{c}(15)$ & $\mathrm{c}(25)$ \\
6. & Education & 0.07 & $\mathrm{c}(16)$ & $\mathrm{c}(26)$ \\
7. Restaurants & 0.05 & $\mathrm{c}(17)$ & $\mathrm{c}(27)$ \\
8. Recreation & 0.05 & $\mathrm{c}(18)$ & $\mathrm{c}(28)$ \\
9. Miscellaneous & 0.22 & $\mathrm{c}(19)$ & $\mathrm{c}(29)$ \\
Sum & \multicolumn{5}{c}{1.00} & 0 & 0 \\
\hline
\end{tabular}

Table A3.3. Demand Equations, Eviews Code

\section{A. Homogeneity constrained}

fooddrink_cons $=c(11)+c(21) *$ income $+\boldsymbol{c}(311) *$ fooddrink_price $+c(312) *$ clothing_price + $c(313) *$ housing_price $+c(314) *$ furnishings_price $+c(315) *$ health_price $+c(316) *$ education_price + $c(317) *$ restaurants_price $+c(318) *$ recreation_price $(c(311)+c(312)+c(313)+c(314)+c(315)+c(316)+c(317)+c(318)) *$ miscellaneous_price clothing_cons $=c(12)+c(22) *$ income $+c(321) *$ fooddrink_price $+\boldsymbol{c}(322) *$ clothing_price + $c(323) *$ housing_price $+c(324) *$ furnishings_price $+c(325) *$ health_price $+c(326) *$ education_price + $c(327) *$ restaurants_price $+c(328) *$ recreation_price $(c(321)+c(322)+c(323)+c(324)+c(325)+c(326)+c(327)+c(328)) *$ miscellaneous_price housing_cons $=c(13)+c(23) *$ income $+c(331) *$ fooddrink_price $+c(332) *$ clothing_price + $c(333) *$ housing_price $+c(334) *$ furnishings_price $+c(335) *$ health_price $+c(336) *$ education_price + $c(337) *$ restaurants_price $+c(338) *$ recreation_price $(c(331)+c(332)+c(333)+c(334)+c(335)+c(336)+c(337)+c(338)) *$ miscellaneous_price furnishings_cons $=c(14)+c(24) *$ income $+c(341) *$ fooddrink_price $+c(342) *$ clothing_price + $c(343) *$ housing_price $+c(344) *$ furnishings_price $+c(345) *$ health_price $+c(346) *$ education_price + $c(347) *$ restaurants_price $+c(348) *$ recreation_price $(c(341)+c(342)+c(343)+c(344)+c(345)+c(346)+c(347)+c(348)) *$ miscellaneous_price health_cons $=c(15)+c(25) *$ income $+c(351) *$ fooddrink_price $+c(352) *$ clothing_price + $c(353) *$ housing_price $+c(354) *$ furnishings_price $+c(355) *$ health_price $+c(356) *$ education_price + $c(357) *$ restaurants_price $+c(358) *$ recreation price $(c(351)+c(352)+c(353)+c(354)+c(355)+c(356)+c(357)+c(358)) *$ miscellaneous_price 
A-13

Table A3.3. Demand Equations, Eviews Code (cont'd)

education_cons $=c(16)+c(26) *$ income $+c(361) *$ fooddrink_price $+c(362) *$ clothing_price + $c(363) * h o u s i n g \_$price $+c(364) *$ furnishings_price $+c(365) *$ health_price $+\boldsymbol{c}(366) *$ education_price + $c(367) *$ restaurants_price $+c(368) *$ recreation_price $(c(361)+c(362)+c(363)+c(364)+c(365)+c(366)+c(367)+c(368)) *$ miscellaneous_price restaurants_cons $=c(17)+c(27) *$ income $+c(371) *$ fooddrink_price $+c(372) *$ clothing_price + $c(373) * h o u s i n g \_$price $+c(374) * f u r n i s h i n g s \_$price $+c(375) *$ health_price $+c(376) *$ education_price + c(377)*restaurants_price $+c(378) *$ recreation_price $(c(371)+c(372)+c(373)+c(374)+c(375)+c(376)+c(377)+c(378)) *$ miscellaneous_price recreation_cons $=c(18)+c(28) *$ income $+c(381) *$ fooddrink_price $+c(382) *$ clothing_price + $c(383) * h o u s i n g \_$price $+c(384) *$ furnishings_price $+c(385) * h e a l t h \_$price $+c(386) *$ education_price + $c(387) *$ restaurants_price $+\mathbf{c}(\mathbf{3 8 8}) *$ recreation_price $(c(381)+c(382)+c(383)+c(384)+c(385)+c(386)+c(387)+c(388)) *$ miscellaneous_price

\section{B. Symmetry constrained}

fooddrink_cons $=c(11)+c(21) *$ income $+c(311) *$ fooddrink price $+c(312) *$ clothing $\_$price + $c(313) * h o u s i n g \_$price $+c(314) *$ furnishings_price $+c(315) * h e a l t h \_$price $+c(316) *$ education_price + $c(317) *$ restaurants_price $+c(318) *$ recreation_price $(c(311)+c(312)+c(313)+c(314)+c(315)+c(316)+c(317)+c(318)) *$ miscellaneous_price clothing_cons $=c(12)+c(22) *$ income $+c(312) *$ fooddrink_price $+\boldsymbol{c}(322) *$ clothing_price + $c(323) * h o u s i n g \_$price $+c(324) *$ furnishings_price $+c(325) * h e a l t h \_$price $+c(326) *$ education_price + $c(327) *$ restaurants_price $+c(328) *$ recreation_price $(c(312)+c(322)+c(323)+c(324)+c(325)+c(326)+c(327)+c(328)) *$ miscellaneous_price housing_cons $=c(13)+c(23) *$ income $+c(313) *$ fooddrink_price $+c(323) *$ clothing_price + $c(333) * h o u s i n g \_$price $+c(334) *$ furnishings_price $+c(335) * h e a l t h \_$price $+c(336) * e d u c a t i o n \_$price + $c(337) *$ restaurants_price $+c(338) *$ recreation_price $(c(313)+c(323)+c(333)+c(334)+c(335)+c(336)+c(337)+c(338)) *$ miscellaneous_price furnishings_cons $=c(14)+c(24) *$ income $+c(314) *$ fooddrink_price $+c(324) *$ clothing_price + $c(334) * h o u s i n g \_$price $+c(344) *$ furnishings_price $+c(345) * h e a l t h \_$price $+c(346) * e d u c a t i o n \_$price + $c(347) *$ restaurants_price $+c(348) *$ recreation_price $(c(314)+c(324)+c(334)+c(344)+c(345)+c(346)+c(347)+c(348)) *$ miscellaneous_price health_cons $=c(15)+c(25) *$ income $+c(315) *$ fooddrink_price $+c(325) *$ clothing_price + $c(335) * h o u s i n g \_$price $+c(345) * f u r n i s h i n g s \_$price $+c(355) *$ health_price $+c(356) * e d u c a t i o n \_$price + $c(357) *$ restaurants_price $+c(358) *$ recreation_price $(c(315)+c(325)+c(335)+c(345)+c(355)+c(356)+c(357)+c(358)) *$ miscellaneous_price education_cons $=c(16)+c(26) *$ income $+c(316) *$ fooddrink_price $+c(326) *$ clothing_price + $c(336) *$ housing_price $+c(346) *$ furnishings_price $+c(356) *$ health_price $+\boldsymbol{c}(366) *$ education_price + $c(367) *$ restaurants_price $+c(368) *$ recreation_price $(c(316)+c(326)+c(336)+c(346)+c(356)+c(366)+c(367)+c(368)) *$ miscellaneous_price 
A-14

Table A3.3. Demand Equations, Eviews Code (cont'd)

restaurants_cons $=c(17)+c(27) *$ income $+c(317) *$ fooddrink_price $+c(327) *$ clothing_price + $c(337) * h o u s i n g \_$price $+c(347) *$ furnishings_price $+c(357) * h e a l t h \_$price $+c(367) *$ education_price + c(377)*restaurants_price $+c(378) *$ recreation_price $(c(317)+c(327)+c(337)+c(347)+c(357)+c(367)+c(377)+c(378)) *$ miscellaneous_price recreation_cons $=c(18)+c(28) *$ income $+c(318) *$ fooddrink_price $+c(328) *$ clothing_price + $c(338) * h o u s i n g \_$price $+c(348) *$ furnishings_price $+c(358) * h e a l t h \_$price $+c(368) *$ education_price + $c(378) *$ restaurants_price $+\boldsymbol{c}(\mathbf{3 8 8}) *$ recreation_price $(c(318)+c(328)+c(338)+c(348)+c(358)+c(368)+c(378)+c(388)) *$ miscellaneous_price

\section{Preference independence}

fooddrink_cons $=c(11)+c(21) *$ income $+c(10) *(0.29+c(21)) *(1-(0.29+c(21))) *$ fooddrink_price $c(10) *(0.29+c(21)) *(0.04+c(22)) *$ clothing_price $-c(10) *(0.29+c(21)) *(0.16+c(23)) * h o u s i n g \_$price $c(10) *(0.29+c(21)) *(0.04+c(24)) *$ furnishings_price $-c(10) *(0.29+c(21)) *(0.08+c(25)) *$ health price $c(10) *(0.29+c(21)) *(0.07+c(26)) *$ education_price $c(10) *(0.29+c(21)) *(0.05+c(27)) *$ restaurants_price $c(10) *(0.29+c(21)) *(0.05+c(28)) *$ recreation_price $-c(10) *(0.29+c(21)) *(0.22-$ $(c(21)+c(22)+c(23)+c(24)+c(25)+c(26)+c(27)+c(28))) *$ miscellaneous_price clothing_cons $=c(12)+c(22) *$ income $-c(10) *(0.04+c(22)) *(0.29+c(21)) *$ fooddrink_price + $c(10) *(0.04+c(22)) *(1-(0.04+c(22))) *$ clothing_price $-c(10) *(0.04+c(22)) *(0.16+c(23)) * h o u s i n g$ price $-c(10) *(0.04+c(22)) *(0.04+c(24)) *$ furnishings_price $-c(10) *(0.04+c(22)) *(0.08+c(25)) *$ health_price $-c(10) *(0.04+c(22)) *(0.07+c(26)) *$ ducation_price $c(10) *(0.04+c(22)) *(0.05+c(27)) *$ restaurants_price $c(10) *(0.04+c(22)) *(0.05+c(28)) *$ recreation_price $-c(10) *(0.04+c(22)) *(0.22-$ $(c(21)+c(22)+c(23)+c(24)+c(25)+c(26)+c(27)+c(28))) *$ miscellaneous_price housing_cons $=c(13)+c(23) *$ income $-c(10) *(0.16+c(23)) *(0.29+c(21)) *$ fooddrink_price $c(10) *(0.16+c(23)) *(0.04+c(22)) *$ clothing_price $+c(10) *(0.16+c(23)) *(1-(0.16+c(23))) *$ housing_price $-c(10) *(0.16+c(23)) *(0.04+c(24)) *$ furnishings_price $-c(10) *(0.16+c(23)) *(0.08+c(25)) * h e a l t h \_$price $-c(10) *(0.16+c(23)) *(0.07+c(26)) *$ education_price $c(10) *(0.16+c(23)) *(0.05+c(27)) *$ restaurants_price $c(10) *(0.16+c(23)) *(0.05+c(28)) *$ recreation_price $-c(10) *(0.16+c(23)) *(0.22-$ $(c(21)+c(22)+c(23)+c(24)+c(25)+c(26)+c(27)+c(28))) *$ miscellaneous_price furnishings_cons $=c(14)+c(24) *$ income $-c(10) *(0.04+c(24)) *(0.29+c(21)) *$ fooddrink_price $c(10) *(0.04+c(24)) *(0.04+c(22)) *$ clothing_price $-c(10) *(0.04+c(24)) *(0.16+c(23)) * h o u s i n g$ p price + $c(10) *(0.04+c(24)) *(1-(0.04+c(24))) *$ furnishings_price $c(10) *(0.04+c(24)) *(0.08+c(25)) *$ health_price $-c(10) *(0.04+c(24)) *(0.07+c(26)) *$ education_price $c(10) *(0.04+c(24)) *(0.05+c(27)) *$ restaurants price $c(10) *(0.04+c(24)) *(0.05+c(28)) *$ recreation_price $-c(10) *(0.04+c(24)) *(0.22-$ $(c(21)+c(22)+c(23)+c(24)+c(25)+c(26)+c(27)+c(28))) *$ miscellaneous_price 
A-15

Table A3.3. Demand Equations, Eviews Code (cont'd)

health_cons $=c(15)+c(25) *$ income $-c(10) *(0.08+c(25)) *(0.29+c(21)) *$ fooddrink_price $c(10) *(0.08+c(25)) *(0.04+c(22)) *$ clothing_price $-c(10) *(0.08+c(25)) *(0.16+c(23)) *$ housing_price $c(10) *(0.08+c(25)) *(0.04+c(24)) *$ furnishings_price $+c(10) *(0.08+c(25)) *(1-$

$(0.08+c(25))) * h e a l t h \_$price $-c(10) *(0.08+c(25)) *(0.07+c(26)) * e d u c a t i o n \_p r i c e-$ $c(10) *(0.08+c(25)) *(0.05+c(27)) *$ restaurants_price -

$c(10) *(0.08+c(25)) *(0.05+c(28)) *$ recreation_price $-c(10) *(0.08+c(25)) *(0.22-$

$(c(21)+c(22)+c(23)+c(24)+c(25)+c(26)+c(27)+c(28))) *$ miscellaneous_price

education_cons $=c(16)+c(26) *$ income $-c(10) *(0.07+c(26)) *(0.29+c(21)) *$ fooddrink_price -

$c(10) *(0.07+c(26)) *(0.04+c(22)) *$ clothing_price $-c(10) *(0.07+c(26)) *(0.16+c(23)) *$ housing_price $c(10) *(0.07+c(26)) *(0.04+c(24)) *$ furnishings_price $-c(10) *(0.07+c(26)) *(0.08+c(25)) *$ health_price + $c(10) *(0.07+c(26)) *(1-(0.07+c(26))) *$ education_price -

$c(10) *(0.07+c(26)) *(0.05+c(27)) *$ restaurants_price -

$c(10) *(0.07+c(26)) *(0.05+c(28)) *$ recreation_price $-c(10) *(0.07+c(26)) *(0.22-$

$(c(21)+c(22)+c(23)+c(24)+c(25)+c(26)+c(27)+c(28))) *$ miscellaneous_price

restaurants_cons $=c(17)+c(27) *$ income $-c(10) *(0.05+c(27)) *(0.29+c(21)) *$ fooddrink_price -

$c(10) *(0.05+c(27)) *(0.04+c(22)) *$ clothing_price $-c(10) *(0.05+c(27)) *(0.16+c(23)) *$ housing price $c(10) *(0.05+c(27)) *(0.04+c(24)) *$ furnishings_price $-c(10) *(0.05+c(27)) *(0.08+c(25)) *$ health price $c(10) *(0.05+c(27)) *(0.07+c(26)) *$ education_price $+\boldsymbol{c}(\mathbf{1 0}) *(\mathbf{0 . 0 5}+\boldsymbol{c}(\mathbf{2 7})) *(\mathbf{1 -}$

$(0.05+c(27))) *$ restaurants_price $-c(10) *(0.05+c(27)) *(0.05+c(28)) *$ recreation_price $c(10) *(0.05+c(27)) *(0.22-$

$(c(21)+c(22)+c(23)+c(24)+c(25)+c(26)+c(27)+c(28))) *$ miscellaneous_price

recreation_cons $=c(18)+c(28) *$ income $-c(10) *(0.05+c(28)) *(0.29+c(21)) *$ fooddrink_price $c(10) *(0.05+c(28)) *(0.04+c(22)) *$ clothing_price $-c(10) *(0.05+c(28)) *(0.16+c(23)) *$ housing_price $c(10) *(0.05+c(28)) *(0.04+c(24)) *$ furnishings_price $-c(10) *(0.05+c(28)) *(0.08+c(25)) *$ health price $c(10) *(0.05+c(28)) *(0.07+c(26)) *$ education_price $c(10) *(0.05+c(28)) *(0.05+c(27)) *$ restaurants_price $+c(10) *(0.05+c(28)) *(1-$

$(0.05+c(28))) *$ recreation_price $-c(10) *(0.05+c(28)) *(0.22-$

$(c(21)+c(22)+c(23)+c(24)+c(25)+c(26)+c(27)+c(28))) *$ miscellaneous_price

\section{No price effects}

$$
\begin{aligned}
& \text { fooddrink_cons }=c(11)+c(21) * \text { income } \\
& \text { clothing_cons }=c(12)+c(22) * \text { income } \\
& \text { housing_cons }=c(13)+c(23) * \text { income } \\
& \text { furnishings_cons }=c(14)+c(24) * \text { income } \\
& \text { health_cons }=c(15)+c(25) * \text { income } \\
& \text { education_cons }=c(16)+c(26) * \text { income } \\
& \text { restaurants_cons }=c(17)+c(27) * \text { income } \\
& \text { recreation_cons }=c(18)+c(28) * \text { income }
\end{aligned}
$$


A-16

Table A3.4. Derived Slutsky Coefficients, Preference Independence, Eviews Code

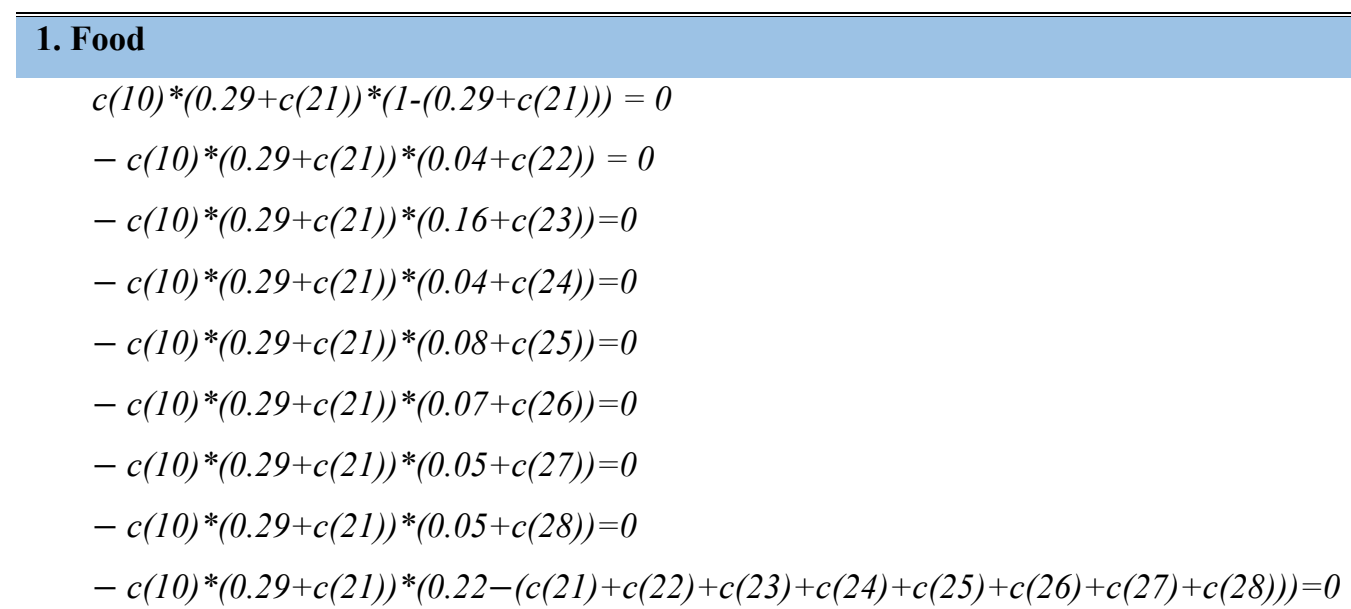

\section{Clothing}

$c(10) *(0.04+c(22)) *(1-(0.04+c(22)))=0$

$-c(10) *(0.04+c(22)) *(0.16+c(23))=0$

$-c(10) *(0.04+c(22)) *(0.04+c(24))=0$

$-c(10) *(0.04+c(22)) *(0.08+c(25))=0$

$-c(10) *(0.04+c(22)) *(0.07+c(26))=0$

$-c(10) *(0.04+c(22)) *(0.05+c(27))=0$

$-c(10) *(0.04+c(22)) *(0.05+c(28))=0$

$-c(10) *(0.04+c(22)) *(0.22-(c(21)+c(22)+c(23)+c(24)+c(25)+c(26)+c(27)+c(28)))=0$

\section{Housing}

$c(10) *(0.16+c(23)) *(1-(0.16+c(23)))=0$

$-c(10) *(0.16+c(23)) *(0.04+c(24))=0$

$-c(10) *(0.16+c(23)) *(0.08+c(25))=0$

$-c(10) *(0.16+c(23)) *(0.07+c(26))=0$

$-c(10) *(0.16+c(23)) *(0.05+c(27))=0$

$-c(10) *(0.16+c(23)) *(0.05+c(28))=0$

$-c(10) *(0.16+c(23)) *(0.22-(c(21)+c(22)+c(23)+c(24)+c(25)+c(26)+c(27)+c(28)))=0$

\section{Furnishings}

$c(10) *(0.04+c(24)) *(1-(0.04+c(24)))=0$

$-c(10) *(0.04+c(24)) *(0.08+c(25))=0$

$-c(10) *(0.04+c(24)) *(0.07+c(26))=0$

$-c(10) *(0.04+c(24)) *(0.05+c(27))=0$

$-c(10) *(0.04+c(24)) *(0.05+c(28))=0$

$-c(10) *(0.04+c(24)) *(0.22-(c(21)+c(22)+c(23)+c(24)+c(25)+c(26)+c(27)+c(28)))=0$

(Continued on next page) 
A-17

Table A3.4. Derived Slutsky Coefficients, Preference Independence, Eviews Code (cont'd)

\section{Health}

$c(10) *(0.08+c(25)) *(1-(0.08+c(25)))=0$

$-c(10) *(0.08+c(25)) *(0.07+c(26))=0$

$-c(10) *(0.08+c(25)) *(0.05+c(27))=0$

$-c(10) *(0.08+c(25)) *(0.05+c(28))=0$

$-c(10) *(0.08+c(25)) *(0.22-(c(21)+c(22)+c(23)+c(24)+c(25)+c(26)+c(27)+c(28)))=0$

\section{Education}

$c(10) *(0.07+c(26)) *(1-(0.07+c(26)))=0$

$-c(10) *(0.07+c(26)) *(0.05+c(27))=0$

$-c(10) *(0.07+c(26)) *(0.05+c(28))=0$

$-c(10) *(0.07+c(26)) *(0.22-(c(21)+c(22)+c(23)+c(24)+c(25)+c(26)+c(27)+c(28)))=0$

\section{Restaurants}

$c(10) *(0.05+c(27)) *(1-(0.05+c(27)))=0$

$-c(10) *(0.05+c(27)) *(0.05+c(28))=0$

$-c(10) *(0.05+c(27)) *(0.22-(c(21)+c(22)+c(23)+c(24)+c(25)+c(26)+c(27)+c(28)))=0$

\section{Recreation}

$c(10) *(0.05+c(28)) *(1-(0.05+c(28)))=0$

$-c(10) *(0.05+c(28)) *(0.22-(c(21)+c(22)+c(23)+c(24)+c(25)+c(26)+c(27)+c(28)))=0$

$c(10) *(0.22-(c(21)+c(22)+c(23)+c(24)+c(25)+c(26)+c(27)+c(28))) *(1-(0.22-(c(21)+c(22)+c(23)+c(24)$

$+c(25)+c(26)+c(27)+c(28))))=0$

$-(c(11)+c(12)+c(13)+c(14)+c(15)+c(16)+c(17)+c(18))=0$

$-(c(21)+c(22)+c(23)+c(24)+c(25)+c(26)+c(27)+c(28))=0$ 


\section{ONLINE SUPPLEMENTARY MATERIALS}

A-18

Table A3.5. Estimates under Preference Independence, Eviews Output

\begin{tabular}{cccccc}
\hline \hline Parameter & Eviews coefficient & Estimate & $\begin{array}{c}\text { Standard. } \\
\text { error }\end{array}$ & t-Statistic & p-value \\
$(1)$ & $(2)$ & $(3)$ & $(4)$ & $(5)$ & $(6)$ \\
\hline \multicolumn{5}{c}{ A. Income flexibility } \\
$\alpha_{1}$ & $\mathrm{C}(10)$ & -0.84 & 0.04 & -19.33 & 0.00 \\
$\alpha_{2}$ & $\mathrm{C}(11)$ & 6.93 & 0.68 & 10.23 & 0.00 \\
$\alpha_{3}$ & $\mathrm{C}(12)$ & 0.38 & 0.18 & 2.10 & 0.04 \\
$\alpha_{4}$ & $\mathrm{C}(13)$ & 2.10 & 0.48 & 4.40 & 0.00 \\
$\alpha_{5}$ & $\mathrm{C}(14)$ & 1.01 & 0.14 & 7.23 & 0.00 \\
$\alpha_{6}$ & $\mathrm{C}(15)$ & -1.49 & 0.22 & -6.69 & 0.00 \\
$\alpha_{7}$ & $\mathrm{C}(16)$ & -0.12 & 0.25 & -0.49 & 0.63 \\
$\alpha_{8}$ & $\mathrm{C}(17)$ & -2.19 & 0.36 & -6.02 & 0.00 \\
$\beta_{1}$ & $\mathrm{C}(18)$ & -3.06 & 0.26 & -11.87 & 0.00 \\
$\beta_{2}$ & & $\mathrm{C}$. Income coefficients & & \\
$\beta_{3}$ & $\mathrm{C}(21)$ & -12.14 & 0.53 & -22.77 & 0.00 \\
$\beta_{4}$ & $\mathrm{C}(22)$ & -0.57 & 0.17 & -3.30 & 0.00 \\
$\beta_{5}$ & $\mathrm{C}(23)$ & 2.97 & 0.42 & 7.12 & 0.00 \\
$\beta_{6}$ & $\mathrm{C}(24)$ & 0.21 & 0.11 & 1.90 & 0.06 \\
$\beta_{7}$ & $\mathrm{C}(25)$ & 2.08 & 0.19 & 11.00 & 0.00 \\
$\beta_{8}$ & $\mathrm{C}(26)$ & 0.16 & 0.23 & 0.67 & 0.51 \\
\hline & $\mathrm{C}(27)$ & 1.70 & 0.31 & 5.40 & 0.00 \\
\hline & $\mathrm{C}(28)$ & 2.11 & 0.17 & 12.29 & 0.00 \\
\hline
\end{tabular}

Note: Except for $\phi$ and p-values, all values are multiplied by 100. Columns (3) and (4) of panels $\mathrm{A}$ and $\mathrm{C}$ are reproduced in panel $\mathrm{C}$ of Table 4 of the main text.

Table A3.6. Estimated Slutsky Coefficients, Preference Independence

\begin{tabular}{|c|c|c|c|c|c|c|c|c|c|}
\hline $\begin{array}{c}\text { Commodity } \\
\text { (1) }\end{array}$ & $\begin{array}{l}\pi_{1 j} \\
(2)\end{array}$ & $\begin{array}{r}\pi_{2 j} \\
(3)\end{array}$ & $\begin{array}{r}\pi_{3 j} \\
(4)\end{array}$ & $\begin{array}{r}\pi_{4 j} \\
(5)\end{array}$ & $\begin{array}{l}\pi_{5 j} \\
(6)\end{array}$ & $\begin{array}{r}\pi_{6 j} \\
(7)\end{array}$ & $\begin{array}{r}\pi_{7 j} \\
(8)\end{array}$ & $\begin{array}{r}\pi_{8 j} \\
(9)\end{array}$ & $\begin{array}{l}\pi_{9 j} \\
(10)\end{array}$ \\
\hline 1. Food & $\begin{array}{c}-11.81 \\
(0.66)\end{array}$ & $\begin{array}{c}0.49 \\
(0.04)\end{array}$ & $\begin{array}{c}2.70 \\
(0.16)\end{array}$ & $\begin{array}{c}0.60 \\
(0.04)\end{array}$ & $\begin{array}{c}1.43 \\
(0.08)\end{array}$ & $\begin{array}{c}1.02 \\
(0.06)\end{array}$ & $\begin{array}{c}0.95 \\
(0.07)\end{array}$ & $\begin{array}{l}1.01 \\
(0.06)\end{array}$ & $\begin{array}{c}3.62 \\
(0.21)\end{array}$ \\
\hline 2. Clothing & & $\begin{array}{l}-2.79 \\
(0.20)\end{array}$ & $\begin{array}{c}0.55 \\
(0.04)\end{array}$ & $\begin{array}{c}0.12 \\
(0.01)\end{array}$ & $\begin{array}{c}0.29 \\
(0.02)\end{array}$ & $\begin{array}{c}0.21 \\
(0.02)\end{array}$ & $\begin{array}{c}0.19 \\
(0.02)\end{array}$ & $\begin{array}{c}0.21 \\
(0.02)\end{array}$ & $\begin{array}{c}0.74 \\
(0.05)\end{array}$ \\
\hline 3. Housing & & & $\begin{array}{l}-12.95 \\
(0.71)\end{array}$ & $\begin{array}{c}0.67 \\
(0.04)\end{array}$ & $\begin{array}{c}1.61 \\
(0.08)\end{array}$ & $\begin{array}{c}1.14 \\
(0.07)\end{array}$ & $\begin{array}{c}1.07 \\
(0.08)\end{array}$ & $\begin{array}{c}1.14 \\
(0.07)\end{array}$ & $\begin{array}{c}4.07 \\
(0.24)\end{array}$ \\
\hline 4. Furnishings & & & & $\begin{array}{l}-3.40 \\
(0.18)\end{array}$ & $\begin{array}{c}0.36 \\
(0.02)\end{array}$ & $\begin{array}{c}0.25 \\
(0.02)\end{array}$ & $\begin{array}{c}0.24 \\
(0.02)\end{array}$ & $\begin{array}{c}0.25 \\
(0.02)\end{array}$ & $\begin{array}{c}0.90 \\
(0.05)\end{array}$ \\
\hline 5. Health & & & & & $\begin{array}{l}-7.64 \\
(0.36)\end{array}$ & $\begin{array}{c}0.61 \\
(0.04)\end{array}$ & $\begin{array}{c}0.57 \\
(0.04)\end{array}$ & $\begin{array}{c}0.60 \\
(0.03)\end{array}$ & $\begin{array}{c}2.16 \\
(0.11)\end{array}$ \\
\hline 6. Education & & & & & & $\begin{array}{l}-5.60 \\
(0.34)\end{array}$ & $\begin{array}{c}0.40 \\
(0.03)\end{array}$ & $\begin{array}{c}0.43 \\
(0.03)\end{array}$ & $\begin{array}{c}1.54 \\
(0.10)\end{array}$ \\
\hline 7. Restaurants & & & & & & & $\begin{array}{l}-5.27 \\
(0.38)\end{array}$ & $\begin{array}{c}0.40 \\
(0.03)\end{array}$ & $\begin{array}{c}1.44 \\
(0.11)\end{array}$ \\
\hline 8. Recreation & & & & & & & & $\begin{array}{l}-5.57 \\
(0.32)\end{array}$ & $\begin{array}{c}1.53 \\
(0.09)\end{array}$ \\
\hline 9. Miscellaneous & & & & & & & & & $\begin{array}{r}-16.00 \\
(0.86)\end{array}$ \\
\hline
\end{tabular}

Note: All entries are multiplied by 100 . Heteroskedasticity-robust standard errors in parentheses. Own-price coefficients and their standard errors are emboldened. These results are reproduced in Panel $\mathrm{C}$ of Table 4 of the main text. 
ONLINE SUPPLEMENTARY MATERIALS

Table A4.1. Income Elasticities

\begin{tabular}{|c|c|c|c|c|c|c|c|c|c|c|c|c|c|c|c|c|c|c|c|}
\hline $\begin{array}{l}\text { Country } \\
\text { (1) }\end{array}$ & $\begin{array}{l}\text { Food } \\
\text { (2) }\end{array}$ & $\begin{array}{l}\text { Cloth. } \\
\text { (3) }\end{array}$ & $\begin{array}{l}\text { Hous. } \\
\text { (4) }\end{array}$ & $\begin{array}{c}\text { Furnish. } \\
\text { (5) }\end{array}$ & $\begin{array}{l}\text { Health } \\
(6)\end{array}$ & $\begin{array}{l}\text { Educ. } \\
\text { (7) }\end{array}$ & $\begin{array}{l}\text { Rest. } \\
(8)\end{array}$ & $\begin{array}{l}\text { Rec. } \\
\text { (9) }\end{array}$ & $\begin{array}{l}\text { Misc. } \\
(10)\end{array}$ & $\begin{array}{c}\text { Country } \\
(1)\end{array}$ & $\begin{array}{l}\text { Food } \\
\text { (2) }\end{array}$ & $\begin{array}{l}\text { Cloth. } \\
\text { (3) }\end{array}$ & $\begin{array}{l}\text { Hous. } \\
\text { (4) }\end{array}$ & $\begin{array}{c}\text { Furnish. } \\
\text { (5) }\end{array}$ & $\begin{array}{l}\text { Health } \\
(6)\end{array}$ & $\begin{array}{l}\text { Educ. } \\
\text { (7) }\end{array}$ & $\begin{array}{l}\text { Rest. } \\
(8)\end{array}$ & $\begin{array}{l}\text { Rec. } \\
(9)\end{array}$ & $\begin{array}{l}\text { Misc. } \\
(10)\end{array}$ \\
\hline \multicolumn{10}{|c|}{ A. First quartile } & \multicolumn{10}{|c|}{ B. Second quartile } \\
\hline 1. Bermuda & -3.56 & 0.88 & 1.14 & 1.06 & 1.15 & 1.05 & 1.14 & 1.17 & 1.14 & 45. Bahamas & 0.23 & 0.89 & 1.14 & 1.06 & 1.19 & 1.05 & 1.17 & 1.29 & 1.16 \\
\hline 2. Luxembourg & -3.78 & 0.86 & 1.13 & 1.06 & 1.14 & 1.05 & 1.14 & 1.18 & 1.14 & 46. Panama & 0.42 & 0.94 & 1.17 & 1.06 & 1.22 & 1.05 & 1.33 & 1.34 & 1.15 \\
\hline 3. United States & -1.25 & 0.84 & 1.14 & 1.06 & 1.15 & 1.05 & 1.15 & 1.19 & 1.14 & 47. Slovak Rep. & 0.28 & 0.90 & 1.14 & 1.06 & 1.19 & 1.05 & 1.21 & 1.26 & 1.16 \\
\hline 4. Hong Kong & -0.79 & 0.90 & 1.13 & 1.07 & 1.16 & 1.05 & 1.17 & 1.24 & 1.14 & 48. Latvia & 0.37 & 0.92 & 1.15 & 1.06 & 1.19 & 1.05 & 1.24 & 1.28 & 1.17 \\
\hline 5. Switzerland & -0.79 & 0.90 & 1.14 & 1.07 & 1.16 & 1.05 & 1.16 & 1.19 & 1.14 & 49. Bahrain & 0.36 & 0.92 & 1.16 & 1.07 & 1.21 & 1.05 & 1.24 & 1.29 & 1.15 \\
\hline 6. Iceland & -0.57 & 0.90 & 1.14 & 1.06 & 1.16 & 1.05 & 1.18 & 1.19 & 1.14 & 50. Curaçao & 0.31 & 0.87 & 1.15 & 1.06 & 1.19 & 1.05 & 1.19 & 1.27 & 1.16 \\
\hline 7. Australia & -0.48 & 0.90 & 1.13 & 1.07 & 1.17 & 1.05 & 1.17 & 1.21 & 1.14 & 51. Mauritius & 0.36 & 0.92 & 1.17 & 1.06 & 1.20 & 1.05 & 1.29 & 1.35 & 1.15 \\
\hline 8. Austria & -0.22 & 0.90 & 1.14 & 1.07 & 1.17 & 1.05 & 1.17 & 1.21 & 1.15 & 52. Anguilla & 0.28 & 0.91 & 1.14 & 1.06 & 1.20 & 1.05 & 1.19 & 1.30 & 1.16 \\
\hline 9. Norway & -0.23 & 0.91 & 1.14 & 1.07 & 1.18 & 1.05 & 1.20 & 1.21 & 1.14 & 53. Tri. \& Tob. & 0.33 & 0.91 & 1.17 & 1.06 & 1.20 & 1.05 & 1.22 & 1.31 & 1.15 \\
\hline 10. Denmark & -0.24 & 0.90 & 1.14 & 1.07 & 1.17 & 1.05 & 1.19 & 1.19 & 1.15 & 54. Kuwait & 0.35 & 0.91 & 1.17 & 1.07 & 1.19 & 1.05 & 1.21 & 1.27 & 1.16 \\
\hline 11. U.K & -0.40 & 0.87 & 1.13 & 1.07 & 1.15 & 1.05 & 1.15 & 1.20 & 1.15 & 55. Romania & 0.38 & 0.92 & 1.14 & 1.06 & 1.20 & 1.06 & 1.24 & 1.27 & 1.17 \\
\hline 12. Cayman Is. & -0.43 & 0.88 & 1.14 & 1.06 & 1.16 & 1.05 & 1.15 & 1.23 & 1.14 & 56. Montserrat & 0.43 & 0.93 & 1.16 & 1.08 & 1.25 & 1.05 & 1.18 & 1.41 & 1.16 \\
\hline 13. Germany & -0.35 & 0.89 & 1.13 & 1.06 & 1.16 & 1.05 & 1.17 & 1.20 & 1.15 & 57. Hungary & 0.35 & 0.90 & 1.15 & 1.06 & 1.20 & 1.05 & 1.24 & 1.28 & 1.16 \\
\hline 14. Finland & -0.20 & 0.91 & 1.14 & 1.07 & 1.17 & 1.05 & 1.18 & 1.20 & 1.15 & 58. Argentina & 0.37 & 0.91 & 1.15 & 1.06 & 1.21 & 1.05 & 1.28 & 1.26 & 1.16 \\
\hline 15. Singapore & -0.12 & 0.90 & 1.13 & 1.07 & 1.17 & 1.05 & 1.17 & 1.28 & 1.15 & 59. Montenegro & 0.40 & 0.92 & 1.15 & 1.05 & 1.20 & 1.05 & 1.60 & 1.24 & 1.16 \\
\hline 16. Netherlands & -0.46 & 0.87 & 1.14 & 1.06 & 1.15 & 1.05 & 1.16 & 1.19 & 1.15 & 60. Turkey & 0.42 & 0.91 & 1.15 & 1.06 & 1.21 & 1.06 & 1.36 & 1.25 & 1.16 \\
\hline 17. Sweden & -0.25 & 0.90 & 1.15 & 1.06 & 1.16 & 1.05 & 1.18 & 1.20 & 1.15 & 61. Malaysia & 0.38 & 0.91 & 1.16 & 1.06 & 1.22 & 1.05 & 1.30 & 1.35 & 1.15 \\
\hline 18. France & -0.18 & 0.90 & 1.13 & 1.07 & 1.17 & 1.05 & 1.18 & 1.21 & 1.15 & 62. St. Kitts \& Nev. & 0.31 & 0.90 & 1.14 & 1.06 & 1.20 & 1.05 & 1.22 & 1.25 & 1.16 \\
\hline 19. Canada & -0.27 & 0.86 & 1.14 & 1.06 & 1.16 & 1.05 & 1.17 & 1.21 & 1.15 & 63. Russia & 0.47 & 0.94 & 1.16 & 1.07 & 1.20 & 1.06 & 1.26 & 1.27 & 1.18 \\
\hline 20. Belgium & -0.48 & 0.87 & 1.14 & 1.06 & 1.16 & 1.05 & 1.17 & 1.20 & 1.15 & 64. Uruguay & 0.34 & 0.91 & 1.15 & 1.06 & 1.20 & 1.05 & 1.23 & 1.31 & 1.16 \\
\hline 21. Taiwan & 0.18 & 0.92 & 1.13 & 1.07 & 1.19 & 1.06 & 1.20 & 1.33 & 1.15 & 65. Chile & 0.35 & 0.91 & 1.15 & 1.07 & 1.21 & 1.05 & 1.20 & 1.27 & 1.17 \\
\hline 22. Cyprus & -0.05 & 0.91 & 1.14 & 1.06 & 1.16 & 1.05 & 1.26 & 1.23 & 1.15 & 66. Costa Rica & 0.40 & 0.93 & 1.16 & 1.07 & 1.22 & 1.05 & 1.24 & 1.36 & 1.16 \\
\hline 23. New Zealand & -0.15 & 0.89 & 1.13 & 1.07 & 1.17 & 1.05 & 1.18 & 1.23 & 1.15 & 67. Barbados & 0.38 & 0.92 & 1.16 & 1.07 & 1.18 & 1.05 & 1.21 & 1.33 & 1.16 \\
\hline 24. Ireland & -0.15 & 0.89 & 1.14 & 1.07 & 1.17 & 1.05 & 1.15 & 1.22 & 1.15 & 68. Bulgaria & 0.48 & 0.91 & 1.15 & 1.06 & 1.22 & 1.05 & 1.30 & 1.32 & 1.17 \\
\hline 25 . Italy & -0.20 & 0.90 & 1.14 & 1.06 & 1.16 & 1.05 & 1.17 & 1.22 & 1.15 & 69. Brunei & 0.46 & 0.90 & 1.16 & 1.05 & 1.24 & 1.06 & 1.30 & 1.33 & 1.15 \\
\hline 26. Malta & 0.20 & 0.91 & 1.15 & 1.06 & 1.18 & 1.05 & 1.36 & 1.26 & 1.15 & 70. Virgin Islands & 0.32 & 0.88 & 1.15 & 1.06 & 1.21 & 1.05 & 1.17 & 1.28 & 1.16 \\
\hline 27. UAE & 0.03 & 0.89 & 1.16 & 1.06 & 1.17 & 1.05 & 1.20 & 1.22 & 1.14 & 71. Oman & 0.36 & 0.89 & 1.16 & 1.06 & 1.20 & 1.05 & 1.21 & 1.30 & 1.15 \\
\hline 28. Japan & -0.03 & 0.89 & 1.14 & 1.06 & 1.18 & 1.05 & 1.18 & 1.24 & 1.15 & 72. Kazakhstan & 0.45 & 0.92 & 1.14 & 1.07 & 1.20 & 1.06 & 1.23 & 1.26 & 1.19 \\
\hline 29. Qatar & 0.16 & 0.87 & 1.15 & 1.06 & 1.18 & 1.05 & 1.18 & 1.24 & 1.15 & 73. Grenada & 0.47 & 0.91 & 1.17 & 1.06 & 1.23 & 1.05 & 1.21 & 1.40 & 1.17 \\
\hline 30. Israel & -0.02 & 0.91 & 1.14 & 1.07 & 1.17 & 1.05 & 1.18 & 1.23 & 1.15 & 74. Mexico & 0.40 & 0.92 & 1.16 & 1.07 & 1.19 & 1.05 & 1.21 & 1.32 & 1.17 \\
\hline 31. Spain & -0.22 & 0.86 & 1.14 & 1.06 & 1.16 & 1.05 & 1.15 & 1.22 & 1.15 & 75. Ant. \& Barb. & 0.42 & 0.91 & 1.16 & 1.06 & 1.20 & 1.05 & 1.22 & 1.33 & 1.17 \\
\hline 32. South Korea & 0.41 & 0.93 & 1.15 & 1.07 & 1.24 & 1.05 & 1.36 & 1.30 & 1.16 & 76. Serbia & 0.52 & 0.92 & 1.16 & 1.07 & 1.23 & 1.05 & 1.27 & 1.31 & 1.18 \\
\hline 33. Portugal & 0.08 & 0.90 & 1.14 & 1.06 & 1.18 & 1.05 & 1.19 & 1.23 & 1.16 & 77. Belarus & 0.57 & 0.94 & 1.18 & 1.06 & 1.23 & 1.06 & 1.25 & 1.34 & 1.19 \\
\hline 34. Lithuania & 0.27 & 0.92 & 1.15 & 1.06 & 1.19 & 1.05 & 1.23 & 1.26 & 1.16 & 78. Dominican Rep. & 0.52 & 0.92 & 1.18 & 1.06 & 1.23 & 1.05 & 1.44 & 1.32 & 1.16 \\
\hline 35. Sint Maarten & 0.19 & 0.86 & 1.18 & 1.05 & 1.19 & 1.05 & 1.18 & 1.23 & 1.14 & 79. Bosn. \& Herz. & 0.51 & 0.92 & 1.17 & 1.06 & 1.23 & 1.05 & 1.36 & 1.31 & 1.17 \\
\hline 36. Slovenia & 0.12 & 0.89 & 1.15 & 1.06 & 1.17 & 1.05 & 1.19 & 1.23 & 1.16 & 80. Turks \& Caicos & 0.43 & 0.90 & 1.16 & 1.06 & 1.19 & 1.05 & 1.21 & 1.32 & 1.17 \\
\hline 37. Greece & 0.09 & 0.89 & 1.14 & 1.06 & 1.17 & 1.05 & 1.24 & 1.25 & 1.15 & 81. Egypt & 0.61 & 0.94 & 1.20 & 1.06 & 1.30 & 1.05 & 1.28 & 1.51 & 1.17 \\
\hline 38. Czech Rep. & 0.19 & 0.88 & 1.13 & 1.06 & 1.19 & 1.05 & 1.20 & 1.25 & 1.16 & 82. Jamaica & 0.59 & 0.93 & 1.17 & 1.08 & 1.22 & 1.06 & 1.43 & 1.47 & 1.18 \\
\hline 39. Aruba & 0.26 & 0.90 & 1.17 & 1.06 & 1.17 & 1.05 & 1.20 & 1.29 & 1.15 & 83. Albania & 0.56 & 0.90 & 1.16 & 1.06 & 1.26 & 1.05 & 1.28 & 1.65 & 1.18 \\
\hline 40. Saudi Arabia & 0.30 & 0.91 & 1.16 & 1.06 & 1.20 & 1.05 & 1.21 & 1.31 & 1.15 & 84. Brazil & 0.45 & 0.89 & 1.17 & 1.06 & 1.19 & 1.05 & 1.23 & 1.31 & 1.17 \\
\hline 41. Croatia & 0.32 & 0.91 & 1.15 & 1.06 & 1.19 & 1.05 & 1.34 & 1.28 & 1.16 & 85. Thailand & 0.55 & 0.92 & 1.17 & 1.06 & 1.23 & 1.05 & 1.33 & 1.44 & 1.17 \\
\hline 42. Estonia & 0.28 & 0.92 & 1.15 & 1.07 & 1.18 & 1.05 & 1.22 & 1.25 & 1.16 & 86. Colombia & 0.52 & 0.90 & 1.16 & 1.06 & 1.23 & 1.05 & 1.28 & 1.30 & 1.18 \\
\hline 43. Poland & 0.35 & 0.93 & 1.15 & 1.06 & 1.20 & 1.05 & 1.24 & 1.26 & 1.16 & 87. Eq. Guinea & 0.50 & 0.91 & 1.17 & 1.06 & 1.24 & 1.05 & 1.29 & 1.39 & 1.17 \\
\hline 44. Seychelles & 0.32 & 0.93 & 1.16 & 1.06 & 1.20 & 1.05 & 1.28 & 1.27 & 1.15 & 88. Macedonia & 0.51 & 0.91 & 1.15 & 1.07 & 1.23 & 1.05 & 1.27 & 1.28 & 1.18 \\
\hline Mean & -0.28 & 0.89 & 1.14 & 1.06 & 1.17 & 1.05 & 1.20 & 1.23 & 1.15 & Mean & 0.42 & 0.91 & 1.16 & 1.06 & 1.21 & 1.05 & 1.26 & 1.32 & 1.17 \\
\hline S.D & 0.82 & 0.02 & 0.01 & 0.01 & 0.02 & 0.00 & 0.05 & 0.04 & 0.01 & S.D & 0.09 & 0.01 & 0.01 & 0.01 & 0.02 & 0.00 & 0.08 & 0.08 & 0.01 \\
\hline
\end{tabular}


ONLINE SUPPLEMENTARY MATERIALS

Table A4.1. Income Elasticities (cont'd)

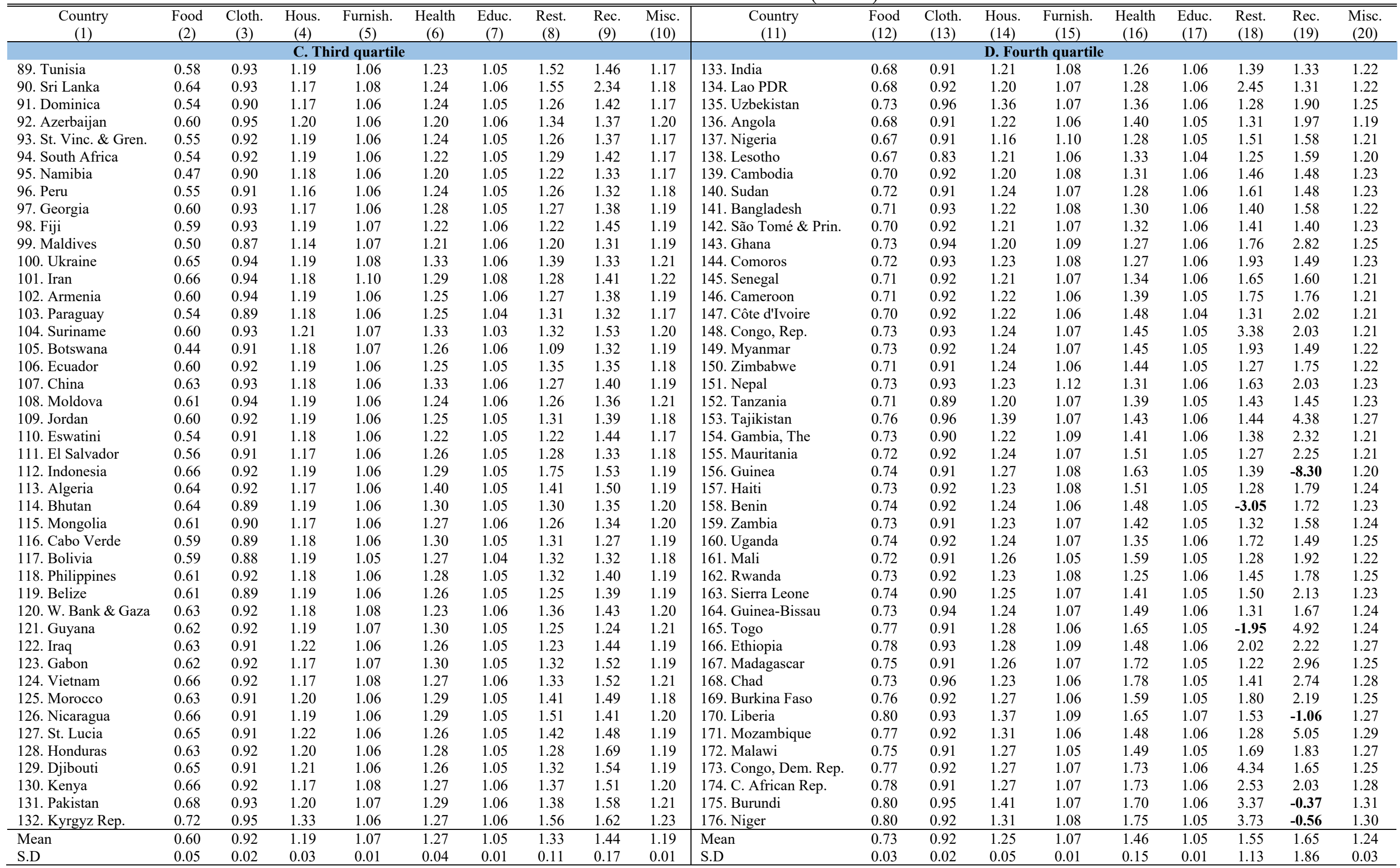

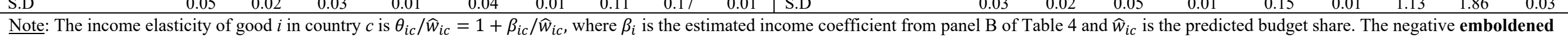
figures are due to small negative values of $\widehat{w}_{i c}$. 
ONLINE SUPPLEMENTARY MATERIALS

\section{A-21}

Table A4.2. Own-Price Elasticities

\begin{tabular}{|c|c|c|c|c|c|c|c|c|c|c|c|c|c|c|c|c|c|c|c|}
\hline $\begin{array}{l}\text { Country } \\
\text { (1) }\end{array}$ & $\begin{array}{l}\text { Food } \\
\text { (2) }\end{array}$ & $\begin{array}{l}\text { Cloth. } \\
\text { (3) }\end{array}$ & $\begin{array}{l}\text { Hous. } \\
\text { (4) }\end{array}$ & $\begin{array}{c}\text { Furnish. } \\
(5)\end{array}$ & $\begin{array}{l}\text { Health } \\
\text { (6) }\end{array}$ & $\begin{array}{c}\text { Educ. } \\
(7)\end{array}$ & $\begin{array}{l}\text { Rest. } \\
\text { (8) }\end{array}$ & $\begin{array}{l}\text { Rec. } \\
(9)\end{array}$ & $\begin{array}{l}\text { Misc. } \\
(10)\end{array}$ & $\begin{array}{c}\text { Country } \\
\text { (11) }\end{array}$ & $\begin{array}{l}\text { Food } \\
(12)\end{array}$ & $\begin{array}{l}\text { Cloth. } \\
\text { (13) }\end{array}$ & $\begin{array}{c}\text { Hous. } \\
(14)\end{array}$ & $\begin{array}{c}\text { Furnish. } \\
\text { (15) }\end{array}$ & $\begin{array}{c}\text { Health } \\
(16)\end{array}$ & $\begin{array}{l}\text { Educ. } \\
\text { (17) }\end{array}$ & $\begin{array}{l}\text { Rest. } \\
(18)\end{array}$ & $\begin{array}{l}\text { Rec. } \\
(19)\end{array}$ & $\begin{array}{l}\text { Misc. } \\
(20)\end{array}$ \\
\hline \multicolumn{10}{|c|}{ A. First quartile } & \multicolumn{10}{|c|}{ B. Second quartile } \\
\hline 1. Bermuda & -4.50 & -1.17 & -0.61 & -0.92 & -0.61 & -0.89 & -0.42 & -0.66 & -0.56 & 45. Bahamas & -0.76 & -1.00 & -0.63 & -0.91 & -0.77 & -0.94 & -0.49 & -1.08 & -0.67 \\
\hline 2. Luxembourg & -4.72 & -1.30 & -0.57 & -0.99 & -0.59 & -0.96 & -0.42 & -0.68 & -0.57 & 46. Panama & -0.57 & -0.61 & -0.76 & -0.92 & -0.91 & -0.93 & -0.97 & -1.28 & -0.62 \\
\hline 3. United States & -2.22 & -1.54 & -0.61 & -0.89 & -0.63 & -0.88 & -0.45 & -0.71 & -0.58 & 47. Slovak Rep. & -0.71 & -0.90 & -0.61 & -1.01 & -0.77 & -1.03 & -0.64 & -0.97 & -0.68 \\
\hline 4. Hong Kong & -1.77 & -0.92 & -0.59 & -1.05 & -0.67 & -0.88 & -0.51 & -0.92 & -0.56 & 48. Latvia & -0.63 & -0.76 & -0.64 & -1.02 & -0.78 & -1.05 & -0.73 & -1.06 & -0.68 \\
\hline 5. Switzerland & -1.76 & -0.96 & -0.61 & -1.05 & -0.68 & -0.97 & -0.48 & -0.72 & -0.57 & 49. Bahrain & -0.63 & -0.79 & -0.72 & -1.04 & -0.85 & -0.91 & -0.70 & -1.08 & -0.63 \\
\hline 6. Iceland & -1.55 & -0.94 & -0.62 & -1.02 & -0.66 & -0.92 & -0.52 & -0.73 & -0.59 & 50. Curaçao & -0.69 & -1.18 & -0.67 & -0.99 & -0.77 & -0.93 & -0.57 & -1.00 & -0.65 \\
\hline 7. Australia & -1.46 & -0.96 & -0.58 & -1.10 & -0.70 & -1.00 & -0.50 & -0.78 & -0.58 & 51. Mauritius & -0.63 & -0.71 & -0.74 & -0.90 & -0.82 & -0.89 & -0.88 & -1.34 & -0.61 \\
\hline 8. Austria & -1.20 & -0.90 & -0.61 & -1.07 & -0.71 & -0.99 & -0.50 & -0.80 & -0.60 & 52. Anguilla & -0.71 & -0.86 & -0.63 & -0.94 & -0.82 & -0.93 & -0.58 & -1.12 & -0.67 \\
\hline 9. Norway & -1.21 & -0.86 & -0.61 & -1.10 & -0.74 & -0.96 & -0.59 & -0.79 & -0.58 & 53. Tri. \& Tob. & -0.66 & -0.82 & -0.75 & -0.88 & -0.81 & -0.88 & -0.64 & -1.17 & -0.63 \\
\hline 10. Denmark & -1.22 & -0.97 & -0.60 & -1.11 & -0.69 & -1.01 & -0.55 & -0.72 & -0.61 & 54. Kuwait & -0.64 & -0.88 & -0.73 & -1.10 & -0.79 & -0.90 & -0.62 & -1.02 & -0.65 \\
\hline 11. U.K & -1.39 & -1.21 & -0.58 & -1.12 & -0.64 & -1.02 & -0.46 & -0.75 & -0.61 & 55. Romania & -0.61 & -0.77 & -0.62 & -1.02 & -0.84 & -1.08 & -0.71 & -1.00 & -0.70 \\
\hline 12. Cayman Is. & -1.41 & -1.14 & -0.64 & -0.91 & -0.68 & -0.87 & -0.45 & -0.88 & -0.59 & 56. Montserrat & -0.56 & -0.65 & -0.71 & -1.21 & -1.03 & -0.87 & -0.54 & -1.54 & -0.66 \\
\hline 13. Germany & -1.33 & -1.07 & -0.59 & -1.01 & -0.66 & -1.01 & -0.52 & -0.75 & -0.61 & 57. Hungary & -0.65 & -0.91 & -0.66 & -0.96 & -0.81 & -0.93 & -0.72 & -1.05 & -0.67 \\
\hline 14. Finland & -1.19 & -0.86 & -0.60 & -1.14 & -0.69 & -1.03 & -0.54 & -0.76 & -0.60 & 58. Argentina & -0.63 & -0.85 & -0.66 & -1.02 & -0.88 & -0.95 & -0.82 & -0.98 & -0.65 \\
\hline 15. Singapore & -1.10 & -0.93 & -0.59 & -1.12 & -0.72 & -0.90 & -0.50 & -1.05 & -0.60 & 59. Montenegro & -0.59 & -0.76 & -0.67 & -0.84 & -0.84 & -0.96 & -1.80 & -0.92 & -0.67 \\
\hline 16. Netherlands & -1.44 & -1.22 & -0.60 & -1.01 & -0.64 & -0.95 & -0.48 & -0.73 & -0.61 & 60. Turkey & -0.57 & -0.84 & -0.67 & -0.92 & -0.86 & -1.07 & -1.07 & -0.96 & -0.67 \\
\hline 17. Sweden & -1.23 & -0.97 & -0.64 & -1.00 & -0.67 & -0.91 & -0.54 & -0.76 & -0.60 & 61. Malaysia & -0.61 & -0.86 & -0.69 & -0.94 & -0.90 & -0.86 & -0.88 & -1.32 & -0.62 \\
\hline 18. France & -1.16 & -0.95 & -0.59 & -1.06 & -0.70 & -1.03 & -0.53 & -0.78 & -0.61 & 62. St. Kitts \& Nev. & -0.68 & -0.94 & -0.63 & -1.01 & -0.82 & -1.03 & -0.66 & -0.96 & -0.66 \\
\hline 19. Canada & -1.25 & -1.27 & -0.61 & -0.92 & -0.67 & -0.94 & -0.50 & -0.79 & -0.61 & 63. Russia & -0.53 & -0.60 & -0.68 & -1.12 & -0.82 & -1.24 & -0.77 & -1.02 & -0.73 \\
\hline 20. Belgium & -1.46 & -1.19 & -0.60 & -0.95 & -0.64 & -0.92 & -0.51 & -0.75 & -0.61 & 64. Uruguay & -0.65 & -0.81 & -0.68 & -1.00 & -0.82 & -0.90 & -0.67 & -1.17 & -0.65 \\
\hline 21. Taiwan & -0.80 & -0.79 & -0.59 & -1.12 & -0.80 & -1.06 & -0.61 & -1.23 & -0.61 & 65. Chile & -0.64 & -0.84 & -0.65 & -1.07 & -0.85 & -0.96 & -0.60 & -1.00 & -0.68 \\
\hline 22. Cyprus & -1.03 & -0.83 & -0.63 & -0.97 & -0.67 & -0.91 & -0.76 & -0.87 & -0.60 & 66. Costa Rica & -0.60 & -0.69 & -0.70 & -1.13 & -0.91 & -0.89 & -0.71 & -1.38 & -0.64 \\
\hline 23. New Zealand & -1.14 & -1.03 & -0.57 & -1.07 & -0.70 & -1.01 & -0.54 & -0.86 & -0.61 & 67. Barbados & -0.61 & -0.76 & -0.71 & -1.04 & -0.75 & -0.97 & -0.64 & -1.23 & -0.67 \\
\hline 24. Ireland & -1.13 & -1.00 & -0.62 & -1.08 & -0.71 & -0.95 & -0.45 & -0.85 & -0.61 & 68. Bulgaria & -0.51 & -0.84 & -0.67 & -0.99 & -0.91 & -0.99 & -0.88 & -1.20 & -0.70 \\
\hline 25. Italy & -1.19 & -0.97 & -0.62 & -0.97 & -0.67 & -0.95 & -0.50 & -0.84 & -0.61 & 69. Brunei & -0.53 & -0.94 & -0.72 & -0.83 & -0.98 & -1.13 & -0.91 & -1.26 & -0.61 \\
\hline 26. Malta & -0.78 & -0.80 & -0.65 & -0.90 & -0.74 & -0.90 & -1.08 & -0.98 & -0.61 & 70. Virgin Islands & -0.67 & -1.12 & -0.65 & -1.02 & -0.86 & -0.91 & -0.50 & -1.07 & -0.67 \\
\hline 27. UAE & -0.96 & -1.04 & -0.70 & -0.94 & -0.71 & -0.89 & -0.60 & -0.85 & -0.59 & 71. Oman & -0.63 & -1.06 & -0.70 & -0.92 & -0.81 & -0.98 & -0.63 & -1.13 & -0.63 \\
\hline 28. Japan & -1.02 & -1.01 & -0.61 & -1.00 & -0.73 & -0.95 & -0.55 & -0.91 & -0.61 & 72. Kazakhstan & -0.54 & -0.73 & -0.63 & -1.09 & -0.83 & -1.19 & -0.68 & -0.99 & -0.77 \\
\hline 29. Qatar & -0.82 & -1.24 & -0.65 & -0.94 & -0.74 & -0.99 & -0.53 & -0.89 & -0.63 & 73. Grenada & -0.52 & -0.85 & -0.74 & -0.93 & -0.97 & -0.89 & -0.61 & -1.51 & -0.68 \\
\hline 30. Israel & -1.01 & -0.80 & -0.62 & -1.18 & -0.69 & -0.97 & -0.53 & -0.88 & -0.62 & 74. Mexico & -0.59 & -0.79 & -0.68 & -1.12 & -0.77 & -0.99 & -0.62 & -1.21 & -0.69 \\
\hline 31. Spain & -1.20 & -1.27 & -0.62 & -0.92 & -0.66 & -0.92 & -0.46 & -0.82 & -0.63 & 75. Ant. \& Barb. & -0.57 & -0.86 & -0.68 & -1.00 & -0.82 & -0.97 & -0.66 & -1.24 & -0.68 \\
\hline 32. South Korea & -0.58 & -0.62 & -0.67 & -1.05 & -0.99 & -0.96 & -1.08 & -1.15 & -0.64 & 76. Serbia & -0.48 & -0.77 & -0.68 & -1.04 & -0.96 & -1.01 & -0.80 & -1.16 & -0.74 \\
\hline 33. Portugal & -0.91 & -0.98 & -0.62 & -0.95 & -0.72 & -0.93 & -0.57 & -0.89 & -0.64 & 77. Belarus & -0.43 & -0.57 & -0.81 & -1.01 & -0.95 & -1.12 & -0.75 & -1.28 & -0.78 \\
\hline 34. Lithuania & -0.72 & -0.71 & -0.66 & -0.95 & -0.78 & -1.02 & -0.68 & -0.98 & -0.65 & 78. Dominican Rep. & -0.48 & -0.76 & -0.78 & -0.97 & -0.94 & -0.91 & -1.32 & -1.23 & -0.67 \\
\hline 35. Sint Maarten & -0.80 & -1.31 & -0.78 & -0.82 & -0.78 & -0.86 & -0.54 & -0.88 & -0.59 & 79. Bosn. \& Herz. & -0.48 & -0.73 & -0.76 & -0.88 & -0.96 & -0.89 & -1.08 & -1.17 & -0.71 \\
\hline 36. Slovenia & -0.87 & -1.01 & -0.65 & -0.94 & -0.71 & -0.94 & -0.57 & -0.88 & -0.64 & 80. Turks \& Caicos & -0.56 & -0.96 & -0.69 & -1.01 & -0.81 & -0.95 & -0.61 & -1.21 & -0.70 \\
\hline 37. Greece & -0.90 & -1.04 & -0.63 & -0.88 & -0.72 & -0.87 & -0.70 & -0.93 & -0.62 & 81. Egypt & -0.38 & -0.59 & -0.89 & -1.02 & -1.23 & -1.02 & -0.84 & -1.93 & -0.72 \\
\hline 38. Czech Rep. & -0.80 & -1.10 & -0.59 & -0.95 & -0.77 & -0.97 & -0.59 & -0.93 & -0.67 & 82. Jamaica & -0.41 & -0.63 & -0.73 & -1.32 & -0.89 & -1.17 & -1.29 & -1.79 & -0.72 \\
\hline 39. Aruba & -0.73 & -0.98 & -0.74 & -0.94 & -0.70 & -0.86 & -0.60 & -1.09 & -0.63 & 83. Albania & -0.43 & -0.92 & -0.68 & -0.90 & -1.08 & -0.96 & -0.82 & -2.44 & -0.73 \\
\hline 40. Saudi Arabia & -0.70 & -0.86 & -0.70 & -0.89 & -0.85 & -0.96 & -0.63 & -1.16 & -0.61 & 84. Brazil & -0.54 & -1.04 & -0.74 & -0.93 & -0.80 & -0.90 & -0.67 & -1.17 & -0.69 \\
\hline 41. Croatia & -0.67 & -0.80 & -0.65 & -0.93 & -0.78 & -0.94 & -1.02 & -1.06 & -0.64 & 85. Thailand & -0.45 & -0.74 & -0.77 & -0.98 & -0.93 & -0.99 & -0.98 & -1.65 & -0.69 \\
\hline 42. Estonia & -0.71 & -0.72 & -0.65 & -1.04 & -0.76 & -1.02 & -0.66 & -0.96 & -0.66 & 86. Colombia & -0.48 & -0.92 & -0.70 & -1.02 & -0.96 & -0.97 & -0.84 & -1.13 & -0.73 \\
\hline 43. Poland & -0.64 & -0.66 & -0.67 & -1.02 & -0.81 & -1.04 & -0.72 & -0.98 & -0.67 & 87. Eq. Guinea & -0.49 & -0.83 & -0.76 & -0.90 & -0.98 & -0.87 & -0.86 & -1.48 & -0.68 \\
\hline 44. Seychelles & -0.67 & -0.70 & -0.69 & -1.00 & -0.82 & -0.98 & -0.85 & -1.03 & -0.62 & 88. Macedonia & -0.49 & -0.82 & -0.67 & -1.07 & -0.94 & -1.01 & -0.81 & -1.06 & -0.76 \\
\hline Mean & -1.26 & $\begin{array}{l}-0.99 \\
\end{array}$ & $\begin{array}{l}-0.63 \\
\end{array}$ & -1.00 & -0.71 & -0.95 & -0.59 & $\begin{array}{l}-0.87 \\
\end{array}$ & -0.61 & Mean & -0.57 & -0.82 & -0.70 & -1.00 & $\begin{array}{c}-0.88 \\
\end{array}$ & -0.97 & -0.79 & -1.23 & -0.68 \\
\hline S.D & 0.81 & 0.19 & 0.04 & 0.08 & 0.07 & 0.05 & 0.16 & 0.13 & 0.03 & S.D & 0.09 & 0.14 & 0.06 & 0.09 & 0.09 & 0.09 & 0.24 & 0.29 & 0.04 \\
\hline
\end{tabular}


ONLINE SUPPLEMENTARY MATERIALS

A-22

Table A4.2. Own-Price Elasticities (cont'd)

\begin{tabular}{|c|c|c|c|c|c|c|c|c|c|c|c|c|c|c|c|c|c|c|c|}
\hline $\begin{array}{c}\text { Country } \\
\text { (1) }\end{array}$ & $\begin{array}{c}\text { Food } \\
(2)\end{array}$ & $\begin{array}{l}\text { Cloth. } \\
\text { (3) }\end{array}$ & $\begin{array}{l}\text { Hous. } \\
\text { (4) }\end{array}$ & $\begin{array}{c}\text { Furnish. } \\
(5)\end{array}$ & $\begin{array}{l}\text { Health } \\
(6)\end{array}$ & $\begin{array}{l}\text { Educ. } \\
\text { (7) }\end{array}$ & $\begin{array}{l}\text { Rest. } \\
(8)\end{array}$ & $\begin{array}{c}\text { Rec. } \\
(9)\end{array}$ & $\begin{array}{l}\text { Misc. } \\
(10)\end{array}$ & $\begin{array}{l}\text { Country } \\
\text { (11) }\end{array}$ & $\begin{array}{c}\text { Food } \\
(12)\end{array}$ & $\begin{array}{l}\text { Cloth. } \\
\text { (13) }\end{array}$ & $\begin{array}{l}\text { Hous. } \\
(14)\end{array}$ & $\begin{array}{c}\text { Furnish. } \\
\text { (15) }\end{array}$ & $\begin{array}{c}\text { Health } \\
(16)\end{array}$ & $\begin{array}{l}\text { Educ. } \\
(17)\end{array}$ & $\begin{array}{l}\text { Rest. } \\
(18)\end{array}$ & $\begin{array}{l}\text { Rec. } \\
(19)\end{array}$ & $\begin{array}{l}\text { Misc. } \\
(20)\end{array}$ \\
\hline \multicolumn{10}{|c|}{ C. Third quartile } & \multicolumn{10}{|c|}{ D. Fourth quartile } \\
\hline 89. Tunisia & -0.42 & -0.66 & -0.85 & -0.92 & -0.94 & -0.91 & -1.54 & -1.72 & -0.70 & 133. India & -0.31 & -0.81 & -0.91 & -1.28 & -1.06 & -1.23 & -1.15 & -1.25 & -0.88 \\
\hline 90. Sri Lanka & -0.35 & -0.68 & -0.76 & -1.22 & -1.00 & -1.14 & -1.64 & -5.05 & -0.73 & 134. Lao PDR & -0.31 & -0.74 & -0.86 & -1.08 & -1.18 & -1.17 & -4.33 & -1.17 & -0.88 \\
\hline 91. Dominica & -0.45 & -0.94 & -0.76 & -1.02 & -0.98 & -0.90 & -0.76 & -1.58 & -0.70 & 135. Uzbekistan & -0.26 & -0.42 & -1.58 & -1.05 & -1.48 & -1.17 & -0.85 & -3.41 & -1.01 \\
\hline 92. Azerbaijan & -0.40 & -0.50 & -0.90 & -0.98 & -0.83 & -1.15 & -1.00 & -1.41 & -0.80 & 136. Angola & -0.31 & -0.87 & -0.97 & -0.97 & -1.67 & -0.89 & -0.91 & -3.66 & -0.79 \\
\hline 93. St. Vinc. \& Gren. & -0.45 & -0.74 & -0.81 & -0.90 & -1.00 & -0.97 & -0.76 & -1.39 & -0.72 & 137. Nigeria & -0.33 & -0.80 & -0.72 & -1.60 & -1.17 & -0.98 & -1.51 & -2.21 & -0.86 \\
\hline 94. South Africa & -0.45 & -0.71 & -0.82 & -1.02 & -0.91 & -0.94 & -0.87 & -1.59 & -0.69 & 138. Lesotho & -0.33 & -1.63 & -0.92 & -0.90 & -1.37 & -0.85 & -0.73 & -2.24 & -0.81 \\
\hline 95. Namibia & -0.52 & -0.93 & -0.78 & -0.96 & -0.81 & -0.91 & -0.65 & -1.25 & -0.70 & 139. Cambodia & -0.30 & -0.72 & -0.87 & -1.29 & -1.28 & -1.11 & -1.38 & -1.83 & -0.93 \\
\hline 96. Peru & -0.44 & -0.86 & -0.72 & -1.01 & -1.00 & -1.01 & -0.76 & -1.22 & -0.75 & 140. Sudan & -0.28 & -0.83 & -1.04 & -1.15 & -1.17 & -1.06 & -1.81 & -1.83 & -0.95 \\
\hline 97. Georgia & -0.40 & -0.70 & -0.75 & -0.98 & -1.15 & -1.05 & -0.80 & -1.44 & -0.80 & 141. Bangladesh & -0.29 & -0.70 & -0.96 & -1.23 & -1.24 & -1.11 & -1.20 & -2.20 & -0.92 \\
\hline 98. Fiji & -0.40 & -0.63 & -0.85 & -1.11 & -0.90 & -1.12 & -0.67 & -1.72 & -0.76 & 142. São Tomé \& Prin. & -0.29 & -0.77 & -0.93 & -1.16 & -1.32 & -1.10 & -1.22 & -1.52 & -0.94 \\
\hline 99. Maldives & -0.49 & -1.25 & -0.63 & -1.09 & -0.87 & -1.11 & -0.58 & -1.16 & -0.77 & 143. Ghana & -0.27 & -0.59 & -0.86 & -1.49 & -1.13 & -1.13 & -2.27 & -6.87 & -1.02 \\
\hline 100. Ukraine & -0.34 & -0.55 & -0.81 & -1.32 & -1.37 & -1.13 & -1.16 & -1.25 & -0.84 & 144. Comoros & -0.28 & -0.66 & -1.03 & -1.26 & -1.14 & -1.08 & -2.77 & -1.85 & -0.96 \\
\hline 101. Iran & -0.33 & -0.52 & -0.78 & -1.55 & -1.19 & -1.52 & -0.82 & -1.55 & -0.90 & 145. Senegal & -0.29 & -0.75 & -0.94 & -1.14 & -1.41 & -1.05 & -1.94 & -2.28 & -0.86 \\
\hline 102. Armenia & -0.40 & -0.58 & -0.83 & -1.02 & -1.02 & -1.16 & -0.79 & -1.43 & -0.79 & 146. Cameroon & -0.29 & -0.75 & -0.97 & -0.96 & -1.61 & -0.89 & -2.22 & -2.88 & -0.88 \\
\hline 103. Paraguay & -0.45 & -1.00 & -0.79 & -0.89 & -1.03 & -0.84 & -0.92 & -1.20 & -0.72 & 147. Côte d'Ivoire & -0.29 & -0.79 & -0.99 & -0.98 & -2.00 & -0.85 & -0.91 & -3.86 & -0.86 \\
\hline 104. Suriname & -0.39 & -0.68 & -0.94 & -1.13 & -1.35 & -0.56 & -0.94 & -1.99 & -0.80 & 148. Congo, Rep. & -0.26 & -0.66 & -1.07 & -1.10 & -1.85 & -0.97 & -7.09 & -3.89 & -0.87 \\
\hline 105. Botswana & -0.55 & -0.86 & -0.79 & -1.13 & -1.06 & -1.06 & -0.27 & -1.22 & -0.77 & 149. Myanmar & -0.27 & -0.76 & -1.05 & -1.07 & -1.85 & -1.02 & -2.78 & -1.85 & -0.90 \\
\hline 106. Ecuador & -0.40 & -0.71 & -0.85 & -1.03 & -1.02 & -0.94 & -1.05 & -1.31 & -0.75 & 150. Zimbabwe & -0.28 & -0.81 & -1.04 & -0.94 & -1.82 & -1.03 & -0.80 & -2.83 & -0.90 \\
\hline 107. China & -0.37 & -0.69 & -0.80 & -1.02 & -1.36 & -1.08 & -0.82 & -1.49 & -0.80 & 151. Nepal & -0.26 & -0.63 & -0.99 & -1.89 & -1.30 & -1.15 & -1.87 & -3.88 & -0.93 \\
\hline 108. Moldova & -0.38 & -0.59 & -0.83 & -1.00 & -0.98 & -1.17 & -0.78 & -1.35 & -0.84 & 152. Tanzania & -0.29 & -1.01 & -0.87 & -1.10 & -1.61 & -0.95 & -1.27 & -1.69 & -0.96 \\
\hline 109. Jordan & -0.40 & -0.77 & -0.84 & -1.00 & -1.02 & -0.99 & -0.92 & -1.48 & -0.74 & 153. Tajikistan & -0.23 & -0.42 & -1.72 & -1.06 & -1.77 & -1.15 & -1.30 & -12.79 & -1.11 \\
\hline 110. Eswatini & -0.46 & -0.86 & -0.79 & -1.00 & -0.92 & -0.96 & -0.67 & -1.67 & -0.70 & 154. Gambia, The & -0.26 & -0.92 & -0.99 & -1.39 & -1.68 & -1.14 & -1.13 & -5.00 & -0.86 \\
\hline 111. El Salvador & -0.43 & -0.85 & -0.75 & -0.99 & -1.06 & -0.93 & -0.82 & -1.25 & -0.76 & 155. Mauritania & -0.27 & -0.76 & -1.06 & -1.13 & -2.12 & -1.02 & -0.80 & -4.74 & -0.88 \\
\hline 112. Indonesia & -0.34 & -0.73 & -0.85 & -1.02 & -1.20 & -0.99 & -2.24 & -2.01 & -0.77 & 156. Guinea & -0.25 & -0.84 & -1.19 & -1.28 & -2.60 & -0.94 & -1.17 & 35.15 & -0.83 \\
\hline 113. Algeria & -0.35 & -0.74 & -0.76 & -1.00 & -1.64 & -0.96 & -1.22 & -1.88 & -0.79 & 157. Haiti & -0.27 & -0.71 & -0.99 & -1.34 & -2.11 & -0.98 & -0.84 & -2.99 & -0.98 \\
\hline 114. Bhutan & -0.36 & -1.01 & -0.82 & -0.98 & -1.23 & -1.02 & -0.88 & -1.33 & -0.81 & 158. Benin & -0.26 & -0.74 & -1.03 & -1.02 & -1.98 & -0.94 & 12.05 & -2.74 & -0.93 \\
\hline 115. Mongolia & -0.38 & -0.90 & -0.75 & -0.99 & -1.12 & -1.08 & -0.78 & -1.30 & -0.83 & 159. Zambia & -0.27 & -0.84 & -1.02 & -1.17 & -1.75 & -1.03 & -0.96 & -2.19 & -1.00 \\
\hline 116. Cabo Verde & -0.40 & -1.00 & -0.80 & -0.91 & -1.23 & -0.92 & -0.92 & -1.02 & -0.77 & 160. Uganda & -0.26 & -0.76 & -1.06 & -1.14 & -1.46 & -1.09 & -2.13 & -1.85 & -1.02 \\
\hline 117. Bolivia & -0.41 & -1.09 & -0.84 & -0.84 & -1.13 & -0.84 & -0.95 & -1.22 & -0.74 & 161. Mali & -0.28 & -0.89 & -1.16 & -0.82 & -2.42 & -0.87 & -0.84 & -3.47 & -0.92 \\
\hline 118. Philippines & -0.39 & -0.76 & -0.80 & -1.02 & -1.15 & -0.92 & -0.96 & -1.52 & -0.77 & 162. Rwanda & -0.27 & -0.78 & -1.00 & -1.29 & -1.01 & -1.13 & -1.35 & -2.94 & -1.03 \\
\hline 119. Belize & -0.38 & -1.05 & -0.84 & -1.02 & -1.09 & -0.89 & -0.74 & -1.48 & -0.78 & 163. Sierra Leone & -0.26 & -0.95 & -1.09 & -1.07 & -1.71 & -0.99 & -1.49 & -4.28 & -0.92 \\
\hline 120. W. Bank \& Gaza & -0.36 & -0.73 & -0.78 & -1.26 & -0.96 & -1.10 & -1.07 & -1.64 & -0.81 & 164. Guinea-Bissau & -0.27 & -0.59 & -1.07 & -1.08 & -2.02 & -1.19 & -0.92 & -2.54 & -0.98 \\
\hline 121. Guyana & -0.38 & -0.80 & -0.84 & -1.10 & -1.24 & -1.03 & -0.76 & -0.91 & -0.84 & 165. Togo & -0.22 & -0.84 & -1.24 & -1.01 & -2.70 & -0.99 & 8.79 & -14.83 & -0.98 \\
\hline 122. Iraq & -0.37 & -0.82 & -0.95 & -0.97 & -1.08 & -0.95 & -0.69 & -1.66 & -0.78 & 166. Ethiopia & -0.22 & -0.65 & -1.25 & -1.36 & -1.97 & -1.18 & -3.05 & -4.61 & -1.13 \\
\hline 123. Gabon & -0.37 & -0.79 & -0.76 & -1.14 & -1.24 & -0.96 & -0.95 & -1.95 & -0.77 & 167. Madagascar & -0.25 & -0.87 & -1.12 & -1.14 & -2.96 & -0.96 & -0.65 & -7.42 & -1.02 \\
\hline 124. Vietnam & -0.34 & -0.73 & -0.76 & -1.27 & -1.12 & -1.16 & -0.98 & -1.97 & -0.85 & 168. Chad & -0.26 & -0.40 & -1.00 & -0.93 & -3.24 & -0.96 & -1.22 & -6.58 & -1.15 \\
\hline 125. Morocco & -0.37 & -0.89 & -0.89 & -0.91 & -1.20 & -0.87 & -1.21 & -1.84 & -0.73 & 169. Burkina Faso & -0.24 & -0.76 & -1.19 & -1.03 & -2.42 & -0.94 & -2.39 & -4.49 & -1.04 \\
\hline 126. Nicaragua & -0.34 & -0.86 & -0.85 & -0.96 & -1.18 & -0.99 & -1.50 & -1.56 & -0.81 & 170. Liberia & -0.20 & -0.69 & -1.62 & -1.41 & -2.67 & -1.34 & -1.57 & 7.80 & -1.13 \\
\hline 127. St. Lucia & -0.34 & -0.86 & -0.98 & -0.93 & -1.06 & -0.95 & -1.26 & -1.81 & -0.77 & 171. Mozambique & -0.23 & -0.77 & -1.36 & -1.00 & -1.99 & -1.09 & -0.84 & -15.32 & -1.17 \\
\hline 128. Honduras & -0.36 & -0.77 & -0.88 & -0.98 & -1.14 & -0.88 & -0.83 & -2.62 & -0.79 & 172. Malawi & -0.25 & -0.87 & -1.17 & -0.83 & -2.01 & -0.90 & -2.07 & -3.15 & -1.09 \\
\hline 129. Djibouti & -0.35 & -0.84 & -0.92 & -1.00 & -1.07 & -0.95 & -0.95 & -2.05 & -0.79 & 173. Congo, Dem. Rep. & -0.23 & -0.76 & -1.18 & -1.18 & -3.03 & -1.07 & -9.96 & -2.46 & -1.02 \\
\hline 130. Kenya & -0.33 & -0.76 & -0.75 & -1.35 & -1.13 & -1.23 & -1.10 & -1.94 & -0.83 & 174. C. African Rep. & -0.22 & -0.83 & -1.17 & -1.14 & -3.02 & -1.13 & -4.57 & -3.90 & -1.14 \\
\hline 131. Pakistan & -0.31 & -0.69 & -0.88 & -1.19 & -1.20 & -1.08 & -1.14 & -2.21 & -0.87 & 175. Burundi & -0.20 & -0.49 & -1.82 & -1.15 & -2.90 & -1.13 & -7.05 & 5.19 & -1.27 \\
\hline 132. Kyrgyz Rep. & -0.28 & -0.43 & -1.44 & -0.97 & -1.11 & -1.13 & -1.68 & -2.34 & -0.96 & 176. Niger & -0.20 & -0.75 & -1.35 & -1.26 & -3.11 & -1.01 & -8.14 & 5.90 & -1.24 \\
\hline Mean & -0.39 & -0.78 & -0.83 & -1.05 & -1.10 & $\begin{array}{l}-1.01 \\
\end{array}$ & -0.97 & -1.66 & -0.78 & Mean & -0.27 & -0.76 & -1.10 & -1.16 & -1.89 & $\begin{array}{l}-1.04 \\
\end{array}$ & -1.65 & -2.44 & -0.98 \\
\hline S.D & 0.05 & 0.16 & 0.11 & 0.14 & 0.16 & 0.14 & 0.34 & 0.63 & 0.06 & S.D & 0.03 & 0.19 & 0.23 & 0.20 & 0.63 & 0.11 & 3.36 & 7.03 & 0.11 \\
\hline
\end{tabular}

Note: The own-price elasticity of good $i$ in country $c$ is $\pi_{i i} / \widehat{w}_{i c}$, where $\pi_{i i}$ is the estimated own-Slutsky coefficient from panel B of Table 4 and $\widehat{w}_{i c}$ is the predicted share. 


\section{A-23}

Table A6.1. Annualised Growth Rates, ICP 2011 - 2017

\begin{tabular}{|c|c|c|c|c|c|c|c|c|c|c|c|c|c|c|c|c|c|c|c|c|c|}
\hline \multirow[b]{2}{*}{$\begin{array}{l}\text { Country } \\
\text { (1) }\end{array}$} & \multirow{2}{*}{$\begin{array}{l}\text { Income } \\
\text { growth } \\
\text { (2) }\end{array}$} & \multicolumn{9}{|c|}{ Price growth } & \multirow[b]{2}{*}{$\begin{array}{l}\text { Country } \\
\text { (12) }\end{array}$} & \multirow{2}{*}{$\begin{array}{l}\text { Income } \\
\text { growth } \\
\text { (13) }\end{array}$} & \multicolumn{9}{|c|}{ Price growth } \\
\hline & & $\begin{array}{l}\text { Food } \\
\text { (3) }\end{array}$ & $\begin{array}{l}\text { Cloth. } \\
\text { (4) }\end{array}$ & $\begin{array}{l}\text { Hous. } \\
\text { (5) }\end{array}$ & $\begin{array}{l}\text { Furnish. } \\
\text { (6) }\end{array}$ & $\begin{array}{l}\text { Health } \\
\text { (7) }\end{array}$ & $\begin{array}{c}\text { Educ. } \\
(8)\end{array}$ & $\begin{array}{l}\text { Rest. } \\
\text { (9) }\end{array}$ & $\begin{array}{l}\text { Rec. } \\
(10)\end{array}$ & $\begin{array}{l}\text { Misc. } \\
(11)\end{array}$ & & & $\begin{array}{l}\text { Food } \\
(14)\end{array}$ & $\begin{array}{l}\text { Cloth. } \\
(15)\end{array}$ & $\begin{array}{l}\text { Hous. } \\
(16)\end{array}$ & $\begin{array}{c}\text { Furnish. } \\
\text { (17) }\end{array}$ & $\begin{array}{l}\text { Health } \\
(18)\end{array}$ & $\begin{array}{l}\text { Educ. } \\
(19)\end{array}$ & $\begin{array}{l}\text { Rest. } \\
(20)\end{array}$ & $\begin{array}{l}\text { Rec. } \\
\text { (21) }\end{array}$ & $\begin{array}{l}\text { Misc. } \\
\text { (22) }\end{array}$ \\
\hline \multicolumn{11}{|c|}{ A. First quartile } & & \multicolumn{10}{|c|}{ B. Second quartile } \\
\hline 1. Luxembourg & 1.37 & 1.70 & 1.56 & 1.09 & -0.43 & -2.40 & 0.75 & -0.34 & -4.38 & -0.65 & 41. Bahamas & 1.76 & 0.06 & 1.52 & -0.08 & -1.31 & -3.95 & -3.46 & -1.23 & 3.44 & 1.65 \\
\hline 2. Hong Kong & 3.37 & 3.70 & 4.89 & 0.47 & 1.94 & 8.44 & -0.85 & -1.01 & 3.48 & 1.42 & 42. Panama & 8.74 & 2.03 & -4.25 & -4.00 & -6.05 & -5.56 & -3.09 & -4.00 & 3.38 & -0.08 \\
\hline 3. Switzerland & 3.63 & -0.34 & -2.40 & -2.38 & -1.99 & -7.32 & -0.93 & -2.39 & -2.19 & -1.87 & 43. Slovak Rep. & 2.35 & 0.87 & 1.35 & 0.44 & -0.21 & -12.22 & 1.28 & 3.90 & 1.13 & 1.88 \\
\hline 4. Iceland & 5.67 & 1.22 & -1.21 & -1.81 & -1.85 & -0.58 & 3.03 & 4.53 & 3.00 & 0.26 & 44. Latvia & 6.26 & 1.34 & 0.07 & 1.65 & -1.51 & -6.98 & 0.35 & -0.05 & -1.50 & 1.44 \\
\hline 5. Australia & 3.55 & 2.07 & -2.64 & 0.50 & 0.15 & -2.92 & 2.09 & 1.30 & -4.43 & -0.52 & 45. Bahrain & -1.17 & 1.69 & 0.21 & -4.19 & 8.71 & -0.99 & -0.90 & 5.03 & -1.49 & 1.88 \\
\hline 6. Austria & 3.53 & 1.15 & 1.38 & 0.29 & -0.81 & -7.50 & 0.32 & 0.42 & -1.75 & -0.61 & 46. Mauritius & 6.14 & 2.67 & 5.83 & -1.81 & 0.60 & 1.95 & -4.26 & -8.16 & 5.13 & -0.35 \\
\hline 7. Norway & 2.05 & 2.14 & 1.78 & 2.62 & 1.54 & 1.37 & 1.67 & 3.24 & -0.22 & 0.75 & 47. Tri. \& Tob. & 4.14 & 1.65 & -1.69 & -6.40 & -1.45 & 2.54 & -0.74 & -2.85 & 3.44 & 1.55 \\
\hline 8. Denmark & 2.79 & -0.78 & 1.85 & 0.01 & -1.56 & -2.96 & 0.04 & -0.30 & -2.24 & -0.59 & 48. Kuwait & 0.69 & 3.23 & -0.97 & -3.00 & 4.48 & -4.22 & -2.79 & 2.25 & -4.18 & 0.33 \\
\hline 9. U. K. & 3.14 & 0.93 & 2.71 & -0.02 & -0.25 & -5.02 & -0.10 & 1.19 & 1.37 & 0.26 & 49. Romania & 8.00 & -0.09 & 0.12 & 1.70 & -0.50 & -9.13 & 2.34 & 0.81 & 0.77 & 1.40 \\
\hline 10. Germany & 3.17 & -0.16 & -0.14 & 1.06 & -1.02 & -3.14 & 2.19 & -1.13 & -1.37 & -0.71 & 50. Hungary & 3.00 & 3.14 & 3.82 & 3.69 & 0.12 & -6.88 & 4.82 & -1.14 & 3.06 & 2.33 \\
\hline 11. Finland & 2.78 & 0.99 & 0.58 & 0.05 & -1.11 & -4.39 & 0.33 & -0.32 & 0.04 & -0.99 & 51. Montenegro & 4.75 & 0.99 & -0.07 & 1.04 & -0.52 & -4.29 & -1.16 & -2.35 & -1.25 & -0.50 \\
\hline 12. Singapore & 3.56 & 0.12 & 1.25 & -1.67 & 2.86 & 0.16 & -2.88 & -2.48 & 3.35 & -0.04 & 52. Turkey & 6.20 & 9.51 & 8.09 & 7.41 & 7.95 & 4.18 & 7.83 & 4.80 & -2.45 & 6.57 \\
\hline 13. Netherlands & 2.29 & 1.08 & 0.12 & 0.68 & 0.06 & -7.54 & 0.84 & -0.13 & -2.22 & -0.69 & 53. Malaysia & 5.32 & 3.38 & 0.58 & -3.66 & 2.24 & 0.31 & -0.72 & -0.37 & 4.20 & 2.65 \\
\hline 14. Sweden & 0.79 & 1.73 & 2.28 & 1.08 & -0.04 & 4.11 & 1.46 & -0.92 & 1.11 & 0.78 & 54. Russia & 3.09 & 6.82 & 9.73 & 9.42 & 4.86 & -4.53 & 5.69 & 3.94 & 0.68 & 5.76 \\
\hline 15. France & 3.67 & 1.08 & 1.43 & -0.33 & -0.55 & -11.86 & 2.13 & -0.93 & -4.06 & -0.89 & 55. Uruguay & 4.29 & 7.54 & 0.73 & 2.10 & 7.43 & 5.43 & 5.67 & 9.24 & 6.91 & 6.43 \\
\hline 16. Canada & 2.55 & -0.33 & 2.82 & 1.02 & 0.05 & 1.20 & 0.31 & 1.55 & -4.34 & -0.26 & 56. Chile & 3.89 & 4.20 & 6.08 & 3.43 & 1.91 & -2.99 & 3.52 & 6.62 & 3.48 & 2.42 \\
\hline 17. Belgium & 2.93 & 0.87 & -0.44 & 0.48 & -0.48 & -3.91 & 0.93 & -0.52 & -2.93 & -0.46 & 57. Costa Rica & 6.83 & 2.20 & -2.40 & -4.17 & 0.73 & -2.51 & -0.80 & 8.66 & 2.37 & -1.91 \\
\hline 18. Taiwan & 2.23 & 3.66 & 1.49 & -0.49 & 1.13 & 2.32 & -0.61 & -2.84 & -0.25 & 0.09 & 58. Barbados & 0.30 & 2.31 & 1.59 & -0.31 & 0.89 & -8.29 & -7.65 & 1.24 & 0.93 & 0.18 \\
\hline 19. Cyprus & 2.27 & -0.28 & 0.11 & -0.66 & -0.52 & 0.99 & -1.12 & -6.24 & -1.60 & -1.76 & 59. Bulgaria & 5.23 & 1.53 & -0.21 & 0.15 & -1.49 & -9.82 & -0.17 & -1.73 & -0.62 & -0.44 \\
\hline 20. New Zealand & 3.43 & 2.04 & -0.94 & 0.44 & -0.75 & -6.42 & 0.89 & 2.14 & -2.29 & -1.44 & 60. Brunei & 5.34 & 0.71 & 2.27 & -14.59 & 7.48 & -0.37 & -10.52 & -11.86 & 0.72 & -1.91 \\
\hline 21. Ireland & 2.86 & 1.21 & 1.51 & -0.04 & -0.82 & -3.64 & -0.42 & 3.68 & -1.17 & -0.69 & 61. Oman & 1.33 & -0.55 & -0.67 & -1.72 & 4.75 & -2.03 & -6.77 & 3.34 & 3.62 & 1.81 \\
\hline 22. Italy & 1.59 & -0.03 & -0.51 & 0.06 & 0.11 & -4.95 & -0.26 & -1.50 & -0.13 & -0.65 & 62. Kazakhstan & 5.23 & 9.00 & 12.02 & 11.68 & 6.32 & -0.88 & 7.86 & 9.44 & 6.69 & 7.70 \\
\hline 23. Malta & 4.13 & 2.40 & 1.62 & 1.37 & -0.26 & -5.44 & 0.33 & -2.11 & -1.58 & 0.50 & 63. Grenada & 7.13 & 0.46 & -6.33 & -3.56 & -1.32 & -0.91 & -9.21 & -5.34 & -2.91 & -0.69 \\
\hline 24. U. A. E. & -0.94 & 0.81 & -0.05 & -1.23 & 5.08 & 9.78 & -5.54 & 5.07 & -0.43 & 1.46 & 64. Mexico & 3.41 & 5.60 & 6.64 & 5.18 & 3.49 & -9.75 & 0.96 & -1.96 & 4.32 & 2.48 \\
\hline 25. Japan & 1.36 & 0.30 & 0.21 & 0.62 & 0.97 & 0.11 & 0.51 & -1.22 & -0.62 & -0.14 & 65. Ant. \& Barb. & 1.76 & 1.37 & -3.28 & -0.16 & -0.65 & -0.64 & 0.35 & 4.89 & 5.14 & 1.21 \\
\hline 26. Qatar & 3.77 & 0.29 & 0.11 & -2.42 & 2.55 & -1.42 & -3.83 & 0.06 & -2.06 & 0.36 & 66. Serbia & 2.52 & 3.34 & 1.53 & 1.93 & 3.14 & -0.12 & 1.26 & 0.96 & -0.64 & 0.86 \\
\hline 27. Israel & 4.58 & 0.31 & -0.11 & 0.30 & -2.55 & -15.19 & -0.48 & 3.98 & 2.55 & -1.05 & 67. Belarus & 3.49 & 21.19 & 20.54 & 21.75 & 18.34 & 13.39 & 19.95 & 26.00 & 20.34 & 18.16 \\
\hline 28. Spain & 3.14 & 0.53 & 0.62 & 0.81 & -1.66 & -8.60 & -2.00 & -2.61 & -1.59 & -1.35 & 68. Bosn. \& Herz. & 4.73 & 0.22 & 1.32 & 0.32 & -2.58 & -5.39 & -1.62 & -1.83 & -2.48 & -0.96 \\
\hline 29. Korea, Rep. & 3.32 & 2.96 & 2.57 & 0.64 & -0.40 & -2.10 & 0.39 & 2.54 & -0.17 & 1.14 & 69. Egypt & 3.28 & 13.12 & 12.94 & 9.44 & 16.78 & 3.48 & 7.00 & 9.09 & 12.09 & 13.74 \\
\hline 30. Portugal & 3.30 & 1.75 & 0.73 & 1.63 & -1.06 & -6.80 & 0.05 & -0.34 & -4.88 & -1.08 & 70. Jamaica & 4.94 & 4.63 & -1.28 & 0.47 & 2.16 & -4.86 & -4.52 & 6.59 & -3.76 & 2.80 \\
\hline 31. Lithuania & 6.40 & 1.02 & 0.97 & 1.61 & -1.74 & -3.07 & 0.84 & -1.86 & -0.66 & 0.05 & 71. Albania & 9.99 & 0.34 & 1.99 & -0.33 & 0.73 & -4.94 & -1.09 & -2.05 & 0.20 & -2.49 \\
\hline 32. Slovenia & 1.96 & 0.28 & 0.65 & 0.45 & 0.24 & -2.37 & -0.71 & -1.69 & -1.55 & -0.71 & 72. Brazil & 1.16 & 8.78 & -2.76 & 5.44 & 5.81 & -1.90 & 3.42 & 4.70 & 12.50 & 7.36 \\
\hline 33. Greece & 0.80 & 0.64 & 1.10 & -0.80 & -1.46 & -3.77 & -2.35 & -6.24 & -3.50 & -2.69 & 73. Thailand & 2.28 & 1.89 & 1.05 & -0.93 & 1.33 & 3.38 & -0.07 & 0.73 & 2.39 & 0.43 \\
\hline 34. Czech Rep. & 4.25 & 1.20 & 1.23 & 0.96 & -0.79 & -7.91 & 1.42 & -1.04 & -5.52 & -0.38 & 74. Colombia & 3.24 & 4.71 & 1.25 & -2.35 & 1.55 & -4.51 & -2.04 & 11.92 & -1.05 & 3.37 \\
\hline 35. Aruba & 1.64 & 0.80 & -1.03 & -7.06 & -1.47 & 0.04 & -10.50 & -1.26 & 0.09 & -2.87 & 75. Eq. Guinea & 6.02 & -0.90 & 2.15 & -5.92 & -0.05 & 7.66 & -1.38 & -5.28 & 2.04 & -8.78 \\
\hline 36. Saudi Arabia & 4.11 & 0.24 & 0.85 & -2.76 & 5.55 & 0.96 & -3.32 & 4.25 & 2.04 & 1.57 & 76. N. Macedonia & 3.63 & 0.97 & 2.17 & 0.50 & -1.16 & -8.03 & 1.22 & -2.76 & -1.37 & -0.87 \\
\hline 37. Croatia & 3.70 & 1.13 & -0.77 & 0.44 & -0.37 & -2.66 & -2.82 & -2.41 & -3.74 & -2.31 & 77. Tunisia & 5.50 & 2.39 & 0.90 & 3.18 & 6.44 & 4.63 & -3.19 & -4.72 & 6.08 & 3.15 \\
\hline 38. Estonia & 5.92 & 2.20 & 1.79 & 1.07 & -0.88 & -7.93 & 2.93 & -0.04 & 1.80 & 1.61 & 78. Sri Lanka & 4.94 & 8.21 & 5.74 & -0.12 & 5.90 & 4.40 & -0.79 & 3.75 & 0.28 & 4.39 \\
\hline 39. Poland & 4.27 & 2.16 & 0.88 & 2.74 & -0.40 & -10.96 & 0.56 & -1.87 & 0.08 & 0.28 & 79. Dominica & 1.94 & -0.31 & 2.26 & -6.29 & 1.19 & -0.78 & -9.43 & -1.51 & -2.37 & 0.91 \\
\hline 40. Seychelles & 8.73 & 2.47 & 0.59 & -3.50 & -1.23 & 0.35 & -3.74 & 4.69 & 7.72 & 2.05 & 80. Azerbaijan & 5.12 & 7.65 & 8.63 & 13.15 & 6.09 & -8.67 & 6.91 & 13.42 & 6.65 & 5.98 \\
\hline Mean & 3.19 & 1.13 & 0.74 & -0.07 & -0.11 & -3.07 & -0.46 & -0.13 & -0.88 & -0.32 & Mean & 4.17 & 3.70 & 2.48 & 1.01 & 2.82 & -2.12 & 0.10 & 2.05 & 2.40 & 2.30 \\
\hline S.D & 1.65 & 1.05 & 1.40 & 1.74 & 1.70 & 4.91 & 2.48 & 2.64 & 2.66 & 1.14 & S.D & 2.32 & 4.29 & 5.03 & 6.14 & 4.75 & 5.33 & 5.53 & 6.62 & 4.76 & 4.37 \\
\hline
\end{tabular}


ONLINE SUPPLEMENTARY MATERIALS

A-24

Table A6.1. Annualised Growth Rates, ICP 2011 - 2017 (cont'd)

\begin{tabular}{|c|c|c|c|c|c|c|c|c|c|c|c|c|c|c|c|c|c|c|c|c|c|}
\hline \multirow[b]{2}{*}{$\begin{array}{c}\text { Country } \\
\text { (1) }\end{array}$} & \multirow{2}{*}{$\begin{array}{l}\text { Income } \\
\text { growth } \\
\text { (2) }\end{array}$} & \multicolumn{9}{|c|}{ Price growth } & \multirow[b]{2}{*}{$\begin{array}{c}\text { Country } \\
\text { (12) }\end{array}$} & \multirow{2}{*}{$\begin{array}{l}\text { Income } \\
\text { growth } \\
\text { (13) }\end{array}$} & \multicolumn{9}{|c|}{ Price growth } \\
\hline & & $\begin{array}{l}\text { Food } \\
\text { (3) }\end{array}$ & $\begin{array}{l}\text { Cloth. } \\
\text { (4) }\end{array}$ & $\begin{array}{l}\text { Hous. } \\
\text { (5) }\end{array}$ & $\begin{array}{c}\text { Furnish. } \\
\text { (6) }\end{array}$ & $\begin{array}{l}\text { Health } \\
(7)\end{array}$ & $\begin{array}{l}\text { Educ. } \\
\text { (8) }\end{array}$ & $\begin{array}{l}\text { Rest. } \\
\text { (9) }\end{array}$ & $\begin{array}{l}\text { Rec. } \\
(10)\end{array}$ & $\begin{array}{l}\text { Misc. } \\
\text { (11) }\end{array}$ & & & $\begin{array}{c}\text { Food } \\
(14)\end{array}$ & $\begin{array}{c}\text { Cloth. } \\
\text { (15) }\end{array}$ & $\begin{array}{c}\text { Hous. } \\
(16)\end{array}$ & $\begin{array}{c}\text { Furnish. } \\
\text { (17) }\end{array}$ & $\begin{array}{c}\text { Health } \\
(18)\end{array}$ & $\begin{array}{l}\text { Educ. } \\
(19)\end{array}$ & $\begin{array}{l}\text { Rest. } \\
(20)\end{array}$ & $\begin{array}{l}\text { Rec. } \\
(21)\end{array}$ & $\begin{array}{l}\text { Misc. } \\
\text { (22) }\end{array}$ \\
\hline & \multicolumn{10}{|c|}{ C. Third quartile } & & \multicolumn{10}{|c|}{ D. Fourth quartile } \\
\hline 81. St. Vinc. \& Gren. & 2.34 & 0.15 & -1.48 & -7.16 & 1.49 & -1.92 & -3.60 & -4.84 & 1.31 & -0.19 & 121. Angola & 7.42 & 10.38 & 2.99 & 3.46 & 8.12 & 7.67 & -3.54 & -2.56 & 6.64 & 1.56 \\
\hline 82. South Africa & 1.81 & 6.61 & 6.94 & -1.09 & 11.12 & 0.79 & -0.96 & -2.29 & 7.26 & 6.24 & 122. Nigeria & -0.08 & 4.99 & 3.45 & 2.75 & 12.49 & -0.23 & -0.67 & 5.06 & 9.92 & 8.98 \\
\hline 83. Namibia & 4.58 & 5.20 & 7.23 & 5.52 & 7.40 & 9.94 & 1.07 & -1.08 & 9.61 & 5.24 & 123. Lesotho & 1.00 & 5.54 & 5.26 & 0.58 & 6.96 & 12.35 & 0.51 & 2.33 & 11.77 & 4.69 \\
\hline 84. Peru & 3.46 & 4.14 & 1.27 & -0.97 & 0.95 & -3.68 & -2.10 & 9.83 & 1.71 & 3.94 & 124. Cambodia & 6.66 & 1.61 & 5.31 & 1.81 & 2.04 & -2.52 & -1.51 & -1.69 & 4.00 & 0.37 \\
\hline 85. Georgia & 3.62 & 2.83 & 6.08 & 6.42 & 0.35 & 2.32 & -1.90 & 5.87 & 1.83 & -1.59 & 125. Sudan & 2.18 & 24.87 & 27.07 & 21.88 & 23.68 & 19.78 & 20.44 & 14.96 & 21.86 & 23.48 \\
\hline 86. Fiji & 6.52 & 3.69 & 2.80 & 0.01 & -1.91 & -12.99 & -3.87 & -2.34 & -2.96 & -1.71 & 126. Bangladesh & 5.73 & 4.72 & 3.79 & 5.16 & -0.59 & 17.02 & 0.05 & 1.46 & 4.63 & 0.57 \\
\hline 87. Maldives & 8.51 & 1.51 & 1.88 & 1.32 & 4.81 & 13.57 & -1.71 & -0.40 & 1.59 & 3.38 & 127. São T. \& Prin. & 5.87 & 1.23 & 3.92 & -0.41 & 4.96 & -2.35 & -5.03 & -0.28 & 3.72 & 0.78 \\
\hline 88. Ukraine & 4.38 & 14.59 & 22.26 & 14.42 & 15.42 & -0.36 & 2.52 & 17.86 & 4.58 & 5.10 & 128. Ghana & -2.24 & 13.35 & 12.90 & 9.25 & 20.85 & 6.93 & 5.49 & 17.11 & 21.76 & 12.09 \\
\hline 89. Iran & 1.02 & 20.24 & 17.94 & 20.13 & 17.24 & 1.80 & 16.61 & 14.37 & 20.49 & 19.21 & 129. Comoros & 3.68 & 0.96 & 3.35 & -6.60 & 0.89 & -12.33 & -3.14 & -3.16 & -0.68 & -3.15 \\
\hline 90. Armenia & 7.08 & -0.37 & 1.68 & 3.57 & -0.20 & -13.69 & -1.37 & 10.20 & 1.45 & 0.86 & 130. Senegal & 1.54 & 0.90 & -4.56 & -3.64 & 1.92 & -1.56 & -0.25 & -2.05 & 0.32 & 0.36 \\
\hline 91. Paraguay & 3.49 & 2.62 & -3.06 & 1.04 & 2.66 & 10.41 & -1.73 & 4.72 & 2.99 & 2.43 & 131. Cameroon & 4.08 & 0.87 & 4.16 & -2.93 & 2.69 & -4.75 & -4.60 & 0.12 & 2.35 & -0.71 \\
\hline 92. Suriname & 7.15 & 9.27 & 12.86 & 1.33 & 7.10 & 1.61 & 7.41 & 7.12 & 9.43 & 8.43 & 132. Côte d'Ivoire & 6.11 & 1.08 & 3.23 & -3.34 & 2.21 & -0.40 & -2.09 & -2.94 & 9.14 & 0.77 \\
\hline 93. Botswana & 4.54 & 3.97 & 4.45 & -0.52 & 5.41 & 9.12 & 2.21 & -3.02 & 6.35 & 3.15 & 133. Congo, Rep. & 5.71 & 0.58 & -0.07 & -4.74 & 0.33 & -4.67 & -2.01 & -2.28 & 1.65 & -2.56 \\
\hline 94. Ecuador & 2.88 & 2.21 & 1.73 & -2.79 & 2.50 & -6.22 & 4.10 & 0.54 & 1.61 & 0.84 & 134. Myanmar & 3.62 & 7.40 & 10.48 & 5.37 & 4.24 & 9.58 & 7.87 & -0.21 & 9.48 & 6.35 \\
\hline 95. China & 6.80 & 3.21 & 8.60 & 1.85 & 0.56 & 4.04 & 2.34 & 1.00 & 1.55 & 3.97 & 135. Zimbabwe & 6.10 & 0.24 & 2.08 & -4.63 & -0.73 & -0.82 & -5.16 & -5.03 & -0.16 & -1.78 \\
\hline 96. Moldova & 6.44 & 4.07 & 5.01 & 7.43 & 2.40 & -5.71 & 5.37 & 1.04 & 3.82 & 1.43 & 136. Nepal & 4.12 & 6.25 & 6.95 & 3.63 & 2.27 & -5.50 & -1.43 & 0.90 & 4.50 & 0.68 \\
\hline 97. Jordan & 0.09 & 0.83 & 2.88 & -0.48 & 3.51 & 0.13 & -2.38 & -0.29 & 2.55 & 2.18 & 137. Tanzania & 7.39 & 4.03 & 5.30 & 3.06 & 6.80 & 9.53 & -2.25 & 4.76 & 10.97 & 7.49 \\
\hline 98. Eswatini & 1.79 & 8.58 & 1.43 & 3.32 & 7.83 & 9.98 & 4.87 & 4.95 & 15.89 & 4.27 & 138. Tajikistan & -1.68 & 8.00 & 7.62 & 9.19 & 7.78 & 4.00 & 7.75 & 7.33 & 13.04 & 9.72 \\
\hline 99. El Salvador & 2.64 & -1.43 & -1.81 & -6.48 & 0.80 & 0.71 & -9.60 & 7.07 & -1.35 & -0.33 & 139. Gambia, The & -0.78 & 5.59 & 6.74 & 1.21 & 9.19 & 8.10 & -3.25 & 3.95 & 11.12 & 2.13 \\
\hline 100. Indonesia & 3.47 & 6.56 & 3.58 & 4.75 & 5.43 & 4.40 & 0.57 & 4.10 & 0.55 & 8.07 & 140. Mauritania & 2.37 & 3.84 & -0.17 & 0.80 & 4.79 & -0.31 & -8.54 & -3.94 & 4.43 & 1.38 \\
\hline 101. Algeria & 1.25 & 6.40 & 5.06 & 0.09 & 5.71 & 1.11 & -3.14 & -4.16 & 6.85 & 6.20 & 141. Guinea & 8.13 & 4.50 & 1.67 & 1.02 & 2.01 & -3.07 & -8.48 & 7.31 & 10.89 & 0.66 \\
\hline 102. Bhutan & 6.81 & 6.47 & 6.39 & 4.15 & 6.64 & 14.94 & 2.04 & -4.65 & -3.89 & 3.65 & 142. Haiti & 2.89 & 7.54 & 1.12 & -1.31 & 8.94 & 1.98 & -6.22 & 11.64 & 8.50 & 8.31 \\
\hline 103. Mongolia & 4.53 & 7.73 & 6.50 & 5.07 & 9.85 & 5.26 & 4.29 & 4.21 & 12.61 & 4.97 & 143. Benin & 5.14 & 0.74 & 3.76 & -4.00 & 5.73 & 3.32 & -2.15 & -6.37 & 0.84 & -0.64 \\
\hline 104. Cabo Verde & 2.75 & 0.53 & 0.67 & 2.39 & 4.04 & 11.60 & -0.20 & -5.32 & -1.11 & 0.39 & 144. Zambia & -2.35 & 8.87 & 8.37 & 6.09 & 12.59 & 3.96 & 3.63 & 7.72 & 11.08 & 9.03 \\
\hline 105. Bolivia & 9.54 & -2.12 & -4.60 & -3.54 & -1.73 & 0.76 & -7.42 & 3.80 & -0.94 & -4.08 & 145. Uganda & -1.72 & 6.32 & 1.89 & 2.49 & 6.96 & 4.62 & 6.73 & 3.44 & 2.33 & 4.34 \\
\hline 106. Philippines & 5.93 & 2.04 & 3.42 & 1.16 & 2.61 & -2.79 & 0.49 & -1.00 & 0.49 & 0.21 & 146. Mali & 3.87 & 0.19 & 2.30 & -4.35 & 0.07 & 9.56 & -1.63 & -14.60 & 6.88 & 1.76 \\
\hline 107. Belize & 2.03 & 0.40 & 0.95 & -3.87 & -0.11 & 5.03 & -8.63 & 13.58 & 0.52 & 0.61 & 147. Rwanda & 3.51 & 2.64 & -0.77 & 2.78 & 1.82 & -3.43 & 1.98 & 9.25 & 4.86 & 0.48 \\
\hline 108. Iraq & 3.23 & 0.08 & -0.31 & -2.69 & 8.02 & 8.50 & -0.90 & 4.79 & 2.90 & 0.76 & 148. Sierra Leone & 7.43 & 3.46 & 5.67 & 1.42 & 7.18 & 4.82 & -0.09 & 3.24 & 8.42 & 3.72 \\
\hline 109. Gabon & 3.38 & -2.28 & 1.36 & -2.94 & 4.37 & -8.06 & -8.27 & 1.32 & 0.63 & -2.61 & 149. Guinea-Bissau & 4.26 & -0.23 & 0.95 & -4.17 & -2.45 & -3.20 & -0.57 & -8.21 & 1.32 & 0.05 \\
\hline 110. Vietnam & 8.68 & 1.83 & 4.18 & 2.68 & -1.80 & -8.76 & -2.54 & -1.96 & 8.41 & 1.47 & 150. Togo & 2.93 & 3.82 & -5.00 & -3.64 & -2.14 & -1.26 & 1.84 & -5.02 & 3.23 & -0.12 \\
\hline 111. Morocco & 1.88 & 0.85 & -0.80 & -2.88 & 3.82 & 2.38 & -3.83 & 3.04 & 1.83 & 3.12 & 151. Ethiopia & 1.56 & 9.66 & 8.82 & 8.69 & 2.63 & 3.46 & 3.47 & 1.83 & 7.92 & 11.71 \\
\hline 112. Nicaragua & 5.51 & 4.13 & -0.06 & 0.81 & 1.01 & -0.96 & 1.79 & 11.16 & -0.49 & 2.85 & 152. Madagascar & -0.17 & 6.05 & 9.09 & 8.16 & 6.89 & 3.75 & 6.98 & -0.54 & 12.75 & 5.51 \\
\hline 113. St. Lucia & -9.41 & 0.41 & -0.78 & -11.31 & 3.01 & 0.89 & -7.68 & -2.07 & 1.23 & 5.12 & 153. Chad & 1.70 & 0.91 & -1.07 & -4.96 & 2.02 & -0.11 & -9.21 & -5.58 & 3.19 & 1.96 \\
\hline 114. Honduras & 5.66 & 2.24 & -4.43 & 0.25 & 2.53 & -7.22 & -4.61 & 2.13 & 3.84 & 1.02 & 154. Burkina Fas & 3.5 & -1.04 & 0.19 & -5.24 & 3.44 & 4.37 & -2.08 & -6.54 & -0.89 & -1.42 \\
\hline 115. Djibouti & 4.28 & 2.07 & -2.51 & -0.87 & -0.75 & 3.25 & -4.75 & -1.44 & 1.02 & -1.49 & 155. Liberia & 6.87 & 7.42 & 7.84 & 2.58 & 5.76 & -7.23 & -0.04 & -15.23 & 5.42 & 4.34 \\
\hline 116. Kenya & 8.96 & 3.05 & 3.89 & -0.13 & 3.44 & 3.32 & -5.35 & 10.56 & 3.96 & 1.00 & 156. Mozambique & 1.89 & 7.14 & 6.80 & 8.27 & 7.44 & 6.15 & 4.66 & 5.74 & 6.30 & 6.95 \\
\hline 117. Pakistan & 4.83 & 5.91 & 6.80 & 2.36 & 3.99 & 2.41 & 0.45 & 5.44 & 11.54 & 4.39 & 157. Malawi & 0.56 & 16.63 & 23.13 & 14.44 & 21.43 & 27.59 & 13.26 & 27.79 & 28.40 & 18.34 \\
\hline 118. Kyrgyz Rep. & 4.02 & 3.01 & 5.47 & 8.62 & 3.42 & -5.84 & 2.86 & 5.19 & 6.00 & 2.00 & 158. Congo, D. R. & 9.31 & 1.82 & 3.75 & -0.50 & 4.62 & 6.40 & -1.11 & 7.81 & 3.92 & 5.16 \\
\hline $\begin{array}{l}\text { 119. India } \\
\text { la }\end{array}$ & 6.71 & 7.28 & 6.83 & 2.56 & 3.89 & 3.44 & 0.51 & 1.72 & 8.18 & 3.46 & 159. Cen. Afr. Rep. & -0.14 & 2.47 & 3.46 & -4.60 & 1.71 & -0.29 & 3.39 & 8.88 & 3.05 & 1.36 \\
\hline 120. Lao PDR & 7.65 & 1.04 & 3.50 & 0.58 & 1.78 & 9.00 & 1.57 & -1.73 & -1.77 & -1.00 & 160. Niger & 0.73 & 1.95 & 5.97 & 2.70 & 3.64 & -6.63 & -4.41 & -1.92 & 4.66 & -0.15 \\
\hline Mean & 4.27 & 3.74 & 3.60 & 1.35 & 3.97 & 1.56 & -0.64 & 2.98 & 3.80 & 2.67 & Mean & 3.22 & 4.93 & 4.94 & 1.69 & 5.53 & 2.86 & 0.21 & 1.61 & 7.09 & 3.86 \\
\hline S.D & 3.21 & 4.27 & 5.29 & 5.36 & 4.16 & 6.74 & 4.86 & 5.59 & 5.07 & 3.84 & S.D & 3.05 & 4.99 & 5.92 & 5.89 & 5.86 & 7.58 & 5.76 & 8.03 & 6.21 & 5.52 \\
\hline
\end{tabular}

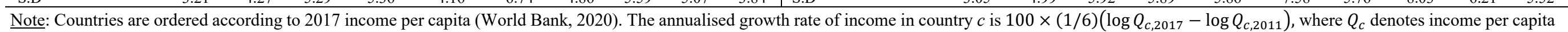
in $c$. The growth rates of prices are similarly computed. 
ONLINE SUPPLEMENTARY MATERIALS

A-25

Table A6.2. Growth Rates of Projected Variables

\begin{tabular}{|c|c|c|c|c|c|c|c|c|c|c|}
\hline \multirow{3}{*}{$\begin{array}{c}\text { Income quartile } \\
\text { (1) }\end{array}$} & \multirow{3}{*}{$\begin{array}{c}2017 \\
\text { level } \\
(2)\end{array}$} & \multicolumn{9}{|c|}{ Annual growth rate } \\
\hline & & 2018 & 2019 & 2020 & 2021 & 2022 & 2023 & 2024 & 2025 & 2026 \\
\hline & & $(3)$ & $(4)$ & $(5)$ & $(6)$ & $(7)$ & $(8)$ & $(9)$ & $(10)$ & $(11)$ \\
\hline & \multicolumn{10}{|c|}{ A. ICP, aggregated food demand (\$ billions) } \\
\hline Q2 & 2,046 & $2.20 \%$ & $2.18 \%$ & $2.16 \%$ & $2.13 \%$ & $2.10 \%$ & $2.08 \%$ & $2.09 \%$ & $2.11 \%$ & $2.13 \%$ \\
\hline Q3 & 3,320 & $3.59 \%$ & $3.57 \%$ & $3.54 \%$ & $3.51 \%$ & $3.49 \%$ & $3.46 \%$ & $3.44 \%$ & $3.43 \%$ & $3.41 \%$ \\
\hline Q4 & 778 & $4.33 \%$ & $4.36 \%$ & $4.39 \%$ & $4.41 \%$ & $4.44 \%$ & $4.46 \%$ & $4.49 \%$ & $4.52 \%$ & $4.55 \%$ \\
\hline Q1 & 2,364 & $0.44 \%$ & $0.37 \%$ & $0.02 \%$ & $0.32 \%$ & $0.29 \%$ & $0.26 \%$ & $0.20 \%$ & $0.18 \%$ & $0.17 \%$ \\
\hline Q2 & 2,046 & $1.62 \%$ & $1.18 \%$ & $-1.75 \%$ & $1.87 \%$ & $1.86 \%$ & $1.45 \%$ & $1.36 \%$ & $1.38 \%$ & $1.41 \%$ \\
\hline Q3 & 3,320 & $2.83 \%$ & $2.16 \%$ & $-1.91 \%$ & $3.84 \%$ & $2.87 \%$ & $2.82 \%$ & $2.75 \%$ & $2.70 \%$ & $2.65 \%$ \\
\hline Q4 & 778 & $3.86 \%$ & $3.97 \%$ & $-0.23 \%$ & $2.91 \%$ & $3.70 \%$ & $3.99 \%$ & $4.04 \%$ & $4.04 \%$ & $3.89 \%$ \\
\hline \multirow[t]{2}{*}{ All countries } & 8,508 & $1.97 \%$ & $1.61 \%$ & $-1.19 \%$ & $2.32 \%$ & $2.02 \%$ & $1.94 \%$ & $1.89 \%$ & $1.89 \%$ & $1.87 \%$ \\
\hline & \multicolumn{10}{|c|}{ C. Population (billions of people) } \\
\hline \multirow[t]{2}{*}{ All countries } & 6.9 & $1.13 \%$ & $1.10 \%$ & $1.06 \%$ & $1.02 \%$ & $0.99 \%$ & $0.96 \%$ & $0.93 \%$ & $0.92 \%$ & $0.90 \%$ \\
\hline & \multicolumn{10}{|c|}{ D. ICP, per capita food demand } \\
\hline Q1 & $2,897.2$ & $0.03 \%$ & $0.04 \%$ & $0.05 \%$ & $0.06 \%$ & $0.07 \%$ & $0.07 \%$ & $0.08 \%$ & $0.10 \%$ & $0.11 \%$ \\
\hline Q2 & $2,075.2$ & $1.28 \%$ & $1.32 \%$ & $1.37 \%$ & $1.42 \%$ & $1.46 \%$ & $1.51 \%$ & $1.54 \%$ & $1.58 \%$ & $1.61 \%$ \\
\hline Q3 & 841.1 & $2.60 \%$ & $2.60 \%$ & $2.61 \%$ & $2.62 \%$ & $2.63 \%$ & $2.64 \%$ & $2.65 \%$ & $2.66 \%$ & $2.67 \%$ \\
\hline Q4 & 676.8 & $1.89 \%$ & $1.94 \%$ & $1.99 \%$ & $2.04 \%$ & $2.09 \%$ & $2.14 \%$ & $2.19 \%$ & $2.24 \%$ & $2.29 \%$ \\
\hline \multirow[t]{2}{*}{ All countries } & $1,233.3$ & $1.29 \%$ & $1.33 \%$ & $1.36 \%$ & $1.39 \%$ & $1.42 \%$ & $1.46 \%$ & $1.49 \%$ & $1.53 \%$ & $1.57 \%$ \\
\hline & \multicolumn{10}{|c|}{ E. IMF, per capita food demand } \\
\hline Q1 & $2,897.2$ & $0.08 \%$ & $0.05 \%$ & $-0.26 \%$ & $0.08 \%$ & $0.10 \%$ & $0.10 \%$ & $0.07 \%$ & $0.06 \%$ & $0.06 \%$ \\
\hline Q2 & $2,075.2$ & $0.71 \%$ & $0.33 \%$ & $-2.51 \%$ & $1.16 \%$ & $1.23 \%$ & $0.88 \%$ & $0.82 \%$ & $0.85 \%$ & $0.90 \%$ \\
\hline Q3 & 841.1 & $1.84 \%$ & $1.21 \%$ & $-2.79 \%$ & $2.94 \%$ & $2.02 \%$ & $2.00 \%$ & $1.96 \%$ & $1.94 \%$ & $1.92 \%$ \\
\hline Q4 & 676.8 & $1.43 \%$ & $1.56 \%$ & $-2.52 \%$ & $0.57 \%$ & $1.37 \%$ & $1.68 \%$ & $1.75 \%$ & $1.77 \%$ & $1.65 \%$ \\
\hline
\end{tabular}

Notes: This table presents the 2017 level and the 2018 - 2026 annual growth rates of key variables underlying the food demand projections.

1. Panels A and B: Aggregated food demand is the sum over countries in the relevant quartile of $Q_{F, c, t+1}=q_{F, c, t+1} \times P o p_{c, t+1}$, where $q_{F, c, t+1}=$ $\exp \left(\log q_{F, c, t}+\Delta \log q_{F, c}\right)$ and $\Delta \log q_{F, c}$ is the change in food demand in country $c$ from the differential demand model and income growth rates from the ICP (World Bank, 2020) and the IMF (2021) (see Appendix A6 for details).

2. Panel C: Population data $\left(P_{0 p} p_{c, t+1}\right)$ are from the United Nations (2019).

3. Panels D and E: Column 1 of panel D gives the ratios of the elements of the same column in panel A to those of panel C. The remaining columns of panel D are the differences between the corresponding columns in panel A and panel C. Panel E is analogous to panel D. 
A-26

Table A7.1. Demand Equations with Quartile Intercepts

\begin{tabular}{|c|c|c|c|c|c|c|c|c|c|c|}
\hline \multirow{2}{*}{$\begin{array}{c}\text { Commodity } i \\
(1)\end{array}$} & \multirow{2}{*}{$\begin{array}{c}\text { Income } \\
\text { coefficient } \\
\beta_{i} \\
(2) \\
\end{array}$} & \multicolumn{9}{|c|}{ Price coefficients } \\
\hline & & $\begin{array}{r}\pi_{1 j} \\
(3)\end{array}$ & $\begin{array}{r}\pi_{2 j} \\
(4)\end{array}$ & $\begin{array}{c}\pi_{3 j} \\
(5)\end{array}$ & $\begin{array}{c}\pi_{4 j} \\
(6)\end{array}$ & $\begin{array}{l}\pi_{5 j} \\
(7)\end{array}$ & $\begin{array}{r}\pi_{6 j} \\
(8)\end{array}$ & $\begin{array}{r}\pi_{7 j} \\
(9)\end{array}$ & $\begin{array}{l}\pi_{8 j} \\
(10)\end{array}$ & $\begin{array}{l}\pi_{9 j} \\
(11)\end{array}$ \\
\hline \multicolumn{11}{|c|}{ A. Homogeneity-constrained } \\
\hline 1. Food & $\begin{array}{c}-6.42 \\
(1.72)\end{array}$ & $\begin{array}{l}-13.34 \\
(3.66)\end{array}$ & $\begin{array}{c}4.99 \\
(2.73)\end{array}$ & $\begin{array}{c}4.62 \\
(3.84)\end{array}$ & $\begin{array}{c}5.08 \\
(3.15)\end{array}$ & $\begin{array}{c}3.10 \\
(1.77)\end{array}$ & $\begin{array}{c}3.35 \\
(2.84)\end{array}$ & $\begin{array}{c}-0.65 \\
(1.89)\end{array}$ & $\begin{array}{l}-3.36 \\
(2.44)\end{array}$ & $\begin{array}{l}-3.79 \\
(4.73)\end{array}$ \\
\hline 2. Clothing & $\begin{array}{c}-0.23 \\
(0.54)\end{array}$ & $\begin{array}{c}2.93 \\
(1.07)\end{array}$ & $\begin{array}{l}-3.48 \\
(0.80)\end{array}$ & $\begin{array}{c}1.65 \\
(1.15)\end{array}$ & $\begin{array}{l}-2.17 \\
(0.95)\end{array}$ & $\begin{array}{l}-1.60 \\
(0.52)\end{array}$ & $\begin{array}{c}1.22 \\
(0.84)\end{array}$ & $\begin{array}{c}-0.63 \\
(0.58)\end{array}$ & $\begin{array}{c}0.30 \\
(0.77)\end{array}$ & $\begin{array}{c}1.78 \\
(1.49)\end{array}$ \\
\hline 3. Housing & $\begin{array}{c}2.50 \\
(1.38)\end{array}$ & $\begin{array}{c}3.14 \\
(2.94)\end{array}$ & $\begin{array}{l}-4.03 \\
(2.15)\end{array}$ & $\begin{array}{l}-6.14 \\
(3.18)\end{array}$ & $\begin{array}{l}-3.24 \\
(2.54)\end{array}$ & $\begin{array}{c}2.49 \\
(1.37)\end{array}$ & $\begin{array}{c}2.19 \\
(2.25)\end{array}$ & $\begin{array}{c}3.34 \\
(1.54)\end{array}$ & $\begin{array}{c}-0.86 \\
(1.99)\end{array}$ & $\begin{array}{c}3.10 \\
(3.87)\end{array}$ \\
\hline 4. Furnishings & $\begin{array}{c}0.62 \\
(0.38)\end{array}$ & $\begin{array}{l}-0.72 \\
(0.74)\end{array}$ & $\begin{array}{c}0.11 \\
(0.55)\end{array}$ & $\begin{array}{c}1.36 \\
(0.82)\end{array}$ & $\begin{array}{l}-5.28 \\
(0.69)\end{array}$ & $\begin{array}{c}1.64 \\
(0.36)\end{array}$ & $\begin{array}{c}1.45 \\
(0.57)\end{array}$ & $\begin{array}{l}-0.39 \\
(0.40)\end{array}$ & $\begin{array}{c}0.15 \\
(0.53)\end{array}$ & $\begin{array}{c}1.68 \\
(0.99)\end{array}$ \\
\hline 5. Health & $\begin{array}{c}0.06 \\
(0.62)\end{array}$ & $\begin{array}{l}-1.82 \\
(1.27)\end{array}$ & $\begin{array}{c}0.92 \\
(0.93)\end{array}$ & $\begin{array}{l}-0.90 \\
(1.46)\end{array}$ & $\begin{array}{c}1.52 \\
(1.17)\end{array}$ & $\begin{array}{c}-8.18 \\
(0.62)\end{array}$ & $\begin{array}{c}2.44 \\
(0.99)\end{array}$ & $\begin{array}{c}0.85 \\
(0.67)\end{array}$ & $\begin{array}{c}2.70 \\
(0.90)\end{array}$ & $\begin{array}{c}2.47 \\
(1.69)\end{array}$ \\
\hline 6. Education & $\begin{array}{l}-0.24 \\
(0.76)\end{array}$ & $\begin{array}{c}1.05 \\
(1.55)\end{array}$ & $\begin{array}{c}0.75 \\
(1.16)\end{array}$ & $\begin{array}{c}0.02 \\
(1.63)\end{array}$ & $\begin{array}{l}-1.02 \\
(1.33)\end{array}$ & $\begin{array}{c}0.65 \\
(0.77)\end{array}$ & $\begin{array}{l}-7.39 \\
(1.24)\end{array}$ & $\begin{array}{l}-0.22 \\
(0.83)\end{array}$ & $\begin{array}{c}2.80 \\
(1.11)\end{array}$ & $\begin{array}{c}3.36 \\
(2.07)\end{array}$ \\
\hline 7. Restaurants & $\begin{array}{l}-0.31 \\
(0.88)\end{array}$ & $\begin{array}{l}-0.61 \\
(1.73)\end{array}$ & $\begin{array}{c}1.34 \\
(1.34)\end{array}$ & $\begin{array}{c}1.88 \\
(1.99)\end{array}$ & $\begin{array}{c}0.32 \\
(1.56)\end{array}$ & $\begin{array}{c}0.85 \\
(0.87)\end{array}$ & $\begin{array}{l}-3.13 \\
(1.42)\end{array}$ & $\begin{array}{l}-3.61 \\
(0.95)\end{array}$ & $\begin{array}{c}0.73 \\
(1.32)\end{array}$ & $\begin{array}{c}2.23 \\
(2.43)\end{array}$ \\
\hline 8. Recreation & $\begin{array}{c}0.04 \\
(0.51)\end{array}$ & $\begin{array}{l}-0.48 \\
(0.97)\end{array}$ & $\begin{array}{c}1.51 \\
(0.78)\end{array}$ & $\begin{array}{l}-1.50 \\
(1.11)\end{array}$ & $\begin{array}{c}1.45 \\
(0.87)\end{array}$ & $\begin{array}{c}0.09 \\
(0.47)\end{array}$ & $\begin{array}{l}-0.08 \\
(0.82)\end{array}$ & $\begin{array}{c}1.21 \\
(0.53)\end{array}$ & $\begin{array}{l}-5.79 \\
(0.72)\end{array}$ & $\begin{array}{c}3.58 \\
(1.37)\end{array}$ \\
\hline 9. Miscellaneous & $\begin{array}{c}3.97 \\
(1.27)\end{array}$ & $\begin{array}{c}9.85 \\
(2.68)\end{array}$ & $\begin{array}{l}-2.11 \\
(1.96)\end{array}$ & $\begin{array}{l}-1.00 \\
(3.14)\end{array}$ & $\begin{array}{c}3.33 \\
(2.43)\end{array}$ & $\begin{array}{c}0.98 \\
(1.27)\end{array}$ & $\begin{array}{l}-0.04 \\
(2.16)\end{array}$ & $\begin{array}{c}0.08 \\
(1.45)\end{array}$ & $\begin{array}{c}3.32 \\
(1.86)\end{array}$ & $\begin{array}{r}-14.41 \\
(3.40)\end{array}$ \\
\hline \multicolumn{11}{|c|}{ B. Symmetry-constrained } \\
\hline 1. Food & $\begin{array}{l}-7.28 \\
(1.79)\end{array}$ & $\begin{array}{l}-11.72 \\
(3.41)\end{array}$ & $\begin{array}{c}3.11 \\
(0.97)\end{array}$ & $\begin{array}{c}4.64 \\
(2.13)\end{array}$ & $\begin{array}{c}-0.43 \\
(0.74)\end{array}$ & $\begin{array}{l}-0.66 \\
(1.01)\end{array}$ & $\begin{array}{c}1.22 \\
(1.43)\end{array}$ & $\begin{array}{l}-1.49 \\
(1.25)\end{array}$ & $\begin{array}{l}-1.39 \\
(0.85)\end{array}$ & $\begin{array}{c}6.72 \\
(2.29)\end{array}$ \\
\hline 2. Clothing & $\begin{array}{l}-0.04 \\
(0.54)\end{array}$ & & $\begin{array}{l}-3.11 \\
(0.75)\end{array}$ & $\begin{array}{c}0.83 \\
(0.98)\end{array}$ & $\begin{array}{l}-0.06 \\
(0.48)\end{array}$ & $\begin{array}{l}-1.17 \\
(0.43)\end{array}$ & $\begin{array}{c}0.74 \\
(0.65)\end{array}$ & $\begin{array}{l}-0.53 \\
(0.50)\end{array}$ & $\begin{array}{c}0.56 \\
(0.50)\end{array}$ & $\begin{array}{l}-0.37 \\
(1.10)\end{array}$ \\
\hline 3. Housing & $\begin{array}{c}2.43 \\
(1.38)\end{array}$ & & & $\begin{array}{l}-11.77 \\
(2.47)\end{array}$ & $\begin{array}{c}1.16 \\
(0.74)\end{array}$ & $\begin{array}{c}1.27 \\
(0.87)\end{array}$ & $\begin{array}{l}-0.31 \\
(1.27)\end{array}$ & $\begin{array}{c}3.75 \\
(1.09)\end{array}$ & $\begin{array}{c}0.17 \\
(0.85)\end{array}$ & $\begin{array}{c}0.25 \\
(1.97)\end{array}$ \\
\hline 4. Furnishings & $\begin{array}{c}0.66 \\
(0.36)\end{array}$ & & & & $\begin{array}{l}-4.70 \\
(0.65)\end{array}$ & $\begin{array}{c}1.53 \\
(0.33)\end{array}$ & $\begin{array}{c}1.04 \\
(0.54)\end{array}$ & $\begin{array}{l}-0.47 \\
(0.39)\end{array}$ & $\begin{array}{c}0.43 \\
(0.44)\end{array}$ & $\begin{array}{c}1.50 \\
(0.95)\end{array}$ \\
\hline 5. Health & $\begin{array}{c}0.36 \\
(0.63)\end{array}$ & & & & & $\begin{array}{l}-7.62 \\
(0.59)\end{array}$ & $\begin{array}{c}1.89 \\
(0.58)\end{array}$ & $\begin{array}{c}0.98 \\
(0.49)\end{array}$ & $\begin{array}{c}1.08 \\
(0.39)\end{array}$ & $\begin{array}{c}2.70 \\
(0.99)\end{array}$ \\
\hline 6. Education & $\begin{array}{c}0.27 \\
(0.79)\end{array}$ & & & & & & $\begin{array}{l}-7.36 \\
(1.21)\end{array}$ & $\begin{array}{l}-0.60 \\
(0.70)\end{array}$ & $\begin{array}{c}1.32 \\
(0.63)\end{array}$ & $\begin{array}{c}2.06 \\
(1.42)\end{array}$ \\
\hline 7. Restaurants & $\begin{array}{l}-0.41 \\
(0.89)\end{array}$ & & & & & & & $\begin{array}{l}-3.70 \\
(0.89)\end{array}$ & $\begin{array}{c}1.19 \\
(0.46)\end{array}$ & $\begin{array}{c}0.86 \\
(1.14)\end{array}$ \\
\hline 8. Recreation & $\begin{array}{c}0.16 \\
(0.50)\end{array}$ & & & & & & & & $\begin{array}{l}-6.37 \\
(0.85)\end{array}$ & $\begin{array}{c}3.00 \\
(1.47)\end{array}$ \\
\hline 9. Miscellaneous & $\begin{array}{c}3.85 \\
(1.33)\end{array}$ & & & & & & & & & $\begin{array}{r}-16.71 \\
(3.20)\end{array}$ \\
\hline \multicolumn{11}{|c|}{ C. No price effects } \\
\hline 1. Food & $\begin{array}{l}-6.47 \\
(1.76)\end{array}$ & & & & & & & & & \\
\hline 2. Clothing & $\begin{array}{l}-0.11 \\
(0.56)\end{array}$ & & & & & & & & & \\
\hline 3. Housing & $\begin{array}{c}2.40 \\
(1.43)\end{array}$ & & & & & & & & & \\
\hline 4. Furnishings & $\begin{array}{c}0.56 \\
(0.42)\end{array}$ & & & & & & & & & \\
\hline 5. Health & $\begin{array}{c}2.18 \\
(0.90)\end{array}$ & & & & & & & & & \\
\hline 6. Education & $\begin{array}{l}-0.44 \\
(0.84)\end{array}$ & & & & & & & & & \\
\hline 7. Restaurants & $\begin{array}{l}-1.05 \\
(0.86)\end{array}$ & & & & & & & & & \\
\hline 8. Recreation & $\begin{array}{c}-0.04 \\
(0.58)\end{array}$ & & & & & & & & & \\
\hline 9. Miscellaneous & $\begin{array}{c}2.96 \\
(1.31)\end{array}$ & & & & & & & & & \\
\hline
\end{tabular}

Note: This table presents three sets of estimates of model (A7.1). Intercepts are included for each income quartile, but these are omitted from this table. All entries are multiplied by 100. Own-price coefficients and their standard errors are emboldened. Standard errors, obtained from 1,000 bootstrap replications, in parentheses. 
ONLINE SUPPLEMENTARY MATERIALS

A-27

Table A7.2. Demand Equations with Quartile Income Slopes

\begin{tabular}{|c|c|c|c|c|c|c|c|c|c|c|c|c|c|}
\hline \multirow{2}{*}{$\begin{array}{c}\text { Commodity } i \\
\text { (1) }\end{array}$} & \multicolumn{4}{|c|}{ Income coefficient $\beta_{i}$} & \multicolumn{9}{|c|}{ Price coefficients } \\
\hline & $\begin{array}{l}\text { Q1 } \\
(2)\end{array}$ & $\begin{array}{l}\text { Q2 } \\
\text { (3) } \\
\end{array}$ & $\begin{array}{l}\text { Q3 } \\
\text { (4) } \\
\end{array}$ & $\begin{array}{l}\text { Q4 } \\
(5) \\
\end{array}$ & $\begin{array}{l}\pi_{1 j} \\
(6) \\
\end{array}$ & $\begin{array}{r}\pi_{2 j} \\
(7) \\
\end{array}$ & $\begin{array}{r}\pi_{3 j} \\
(8) \\
\end{array}$ & $\begin{array}{l}\pi_{4 j} \\
(9) \\
\end{array}$ & $\begin{array}{c}\pi_{5 j} \\
(10) \\
\end{array}$ & $\begin{array}{c}\pi_{6 j} \\
(11) \\
\end{array}$ & $\begin{array}{l}\pi_{7 j} \\
(12) \\
\end{array}$ & $\begin{array}{l}\pi_{8 j} \\
(13) \\
\end{array}$ & $\begin{array}{r}\pi_{9 j} \\
(14) \\
\end{array}$ \\
\hline \multicolumn{14}{|c|}{ A. Homogeneity-constrained } \\
\hline 1. Food & $\begin{array}{l}-1.78 \\
(4.87)\end{array}$ & $\begin{array}{r}-14.87 \\
(4.74)\end{array}$ & $\begin{array}{l}-6.11 \\
(4.18)\end{array}$ & $\begin{array}{l}-5.81 \\
(2.31)\end{array}$ & $\begin{array}{l}-12.97 \\
(3.29)\end{array}$ & $\begin{array}{c}5.49 \\
(2.61)\end{array}$ & $\begin{array}{c}4.07 \\
(4.04)\end{array}$ & $\begin{array}{c}4.23 \\
(3.20)\end{array}$ & $\begin{array}{c}3.32 \\
(1.70)\end{array}$ & $\begin{array}{c}4.23 \\
(2.84)\end{array}$ & $\begin{array}{l}-0.64 \\
(1.77)\end{array}$ & $\begin{array}{l}-3.31 \\
(2.57)\end{array}$ & $\begin{array}{l}-4.42 \\
(4.93)\end{array}$ \\
\hline 2. Clothing & $\begin{array}{c}-0.76 \\
(1.49)\end{array}$ & $\begin{array}{c}0.13 \\
(1.45)\end{array}$ & $\begin{array}{c}-0.97 \\
(1.28)\end{array}$ & $\begin{array}{c}0.06 \\
(0.71)\end{array}$ & $\begin{array}{c}2.92 \\
(1.01)\end{array}$ & $\begin{array}{c}-3.43 \\
(0.80)\end{array}$ & $\begin{array}{c}1.74 \\
(1.23)\end{array}$ & $\begin{array}{l}-2.19 \\
(0.98)\end{array}$ & $\begin{array}{c}-1.60 \\
(0.52)\end{array}$ & $\begin{array}{c}1.12 \\
(0.87)\end{array}$ & $\begin{array}{l}-0.66 \\
(0.54)\end{array}$ & $\begin{array}{c}0.32 \\
(0.79)\end{array}$ & $\begin{array}{c}1.77 \\
(1.51)\end{array}$ \\
\hline 3. Housing & $\begin{array}{l}-1.49 \\
(3.95)\end{array}$ & $\begin{array}{l}12.99 \\
(3.85)\end{array}$ & $\begin{array}{c}3.46 \\
(3.39)\end{array}$ & $\begin{array}{c}1.01 \\
(1.87)\end{array}$ & $\begin{array}{c}2.97 \\
(2.67)\end{array}$ & $\begin{array}{l}-4.06 \\
(2.12)\end{array}$ & $\begin{array}{l}-4.93 \\
(3.28)\end{array}$ & $\begin{array}{l}-2.73 \\
(2.60)\end{array}$ & $\begin{array}{c}2.38 \\
(1.38)\end{array}$ & $\begin{array}{c}0.62 \\
(2.30)\end{array}$ & $\begin{array}{c}3.25 \\
(1.44)\end{array}$ & $\begin{array}{l}-1.38 \\
(2.09)\end{array}$ & $\begin{array}{c}3.88 \\
(4.00)\end{array}$ \\
\hline 4. Furnishings & $\begin{array}{c}-0.45 \\
(1.05)\end{array}$ & $\begin{array}{c}1.74 \\
(1.02)\end{array}$ & $\begin{array}{c}1.78 \\
(0.90)\end{array}$ & $\begin{array}{c}0.62 \\
(0.49)\end{array}$ & $\begin{array}{c}-0.17 \\
(0.71)\end{array}$ & $\begin{array}{c}-0.42 \\
(0.56)\end{array}$ & $\begin{array}{c}1.18 \\
(0.87)\end{array}$ & $\begin{array}{l}-4.76 \\
(0.69)\end{array}$ & $\begin{array}{c}1.72 \\
(0.36)\end{array}$ & $\begin{array}{c}1.26 \\
(0.61)\end{array}$ & $\begin{array}{l}-0.72 \\
(0.38)\end{array}$ & $\begin{array}{c}0.03 \\
(0.55)\end{array}$ & $\begin{array}{c}1.88 \\
(1.06)\end{array}$ \\
\hline 5. Health & $\begin{array}{c}6.15 \\
(1.90)\end{array}$ & $\begin{array}{c}0.37 \\
(1.84)\end{array}$ & $\begin{array}{c}0.29 \\
(1.63)\end{array}$ & $\begin{array}{c}-0.03 \\
(0.90)\end{array}$ & $\begin{array}{c}1.74 \\
(1.28)\end{array}$ & $\begin{array}{c}0.22 \\
(1.02)\end{array}$ & $\begin{array}{l}-1.39 \\
(1.57)\end{array}$ & $\begin{array}{c}2.59 \\
(1.25)\end{array}$ & $\begin{array}{c}-7.08 \\
(\mathbf{0 . 6 6})\end{array}$ & $\begin{array}{c}2.03 \\
(1.10)\end{array}$ & $\begin{array}{l}-0.85 \\
(0.69)\end{array}$ & $\begin{array}{c}1.01 \\
(1.00)\end{array}$ & $\begin{array}{c}1.74 \\
(1.92)\end{array}$ \\
\hline 6. Education & $\begin{array}{l}-1.08 \\
(2.19)\end{array}$ & $\begin{array}{l}-1.33 \\
(2.13)\end{array}$ & $\begin{array}{c}-0.47 \\
(1.88)\end{array}$ & $\begin{array}{c}0.26 \\
(1.04)\end{array}$ & $\begin{array}{c}0.92 \\
(1.48)\end{array}$ & $\begin{array}{c}0.83 \\
(1.18)\end{array}$ & $\begin{array}{c}0.07 \\
(1.82)\end{array}$ & $\begin{array}{l}-1.22 \\
(1.44)\end{array}$ & $\begin{array}{c}0.61 \\
(0.76)\end{array}$ & $\begin{array}{l}-7.42 \\
(1.28)\end{array}$ & $\begin{array}{c}-0.21 \\
(0.80)\end{array}$ & $\begin{array}{c}2.95 \\
(1.16)\end{array}$ & $\begin{array}{c}3.46 \\
(2.22)\end{array}$ \\
\hline 7. Restaurants & $\begin{array}{l}-2.59 \\
(2.49)\end{array}$ & $\begin{array}{l}-1.10 \\
(2.42)\end{array}$ & $\begin{array}{l}-1.95 \\
(2.14)\end{array}$ & $\begin{array}{c}0.29 \\
(1.18)\end{array}$ & $\begin{array}{l}-1.98 \\
(1.68)\end{array}$ & $\begin{array}{c}1.21 \\
(1.34)\end{array}$ & $\begin{array}{c}1.53 \\
(2.06)\end{array}$ & $\begin{array}{c}0.32 \\
(1.64)\end{array}$ & $\begin{array}{c}0.39 \\
(0.87)\end{array}$ & $\begin{array}{l}-2.43 \\
(1.45)\end{array}$ & $\begin{array}{c}-2.93 \\
(0.90)\end{array}$ & $\begin{array}{c}1.64 \\
(1.32)\end{array}$ & $\begin{array}{c}2.25 \\
(2.52)\end{array}$ \\
\hline 8. Recreation & $\begin{array}{c}1.07 \\
(1.40)\end{array}$ & $\begin{array}{c}1.35 \\
(1.36)\end{array}$ & $\begin{array}{c}0.47 \\
(1.20)\end{array}$ & $\begin{array}{c}-0.80 \\
(0.66)\end{array}$ & $\begin{array}{l}-0.71 \\
(0.94)\end{array}$ & $\begin{array}{c}1.42 \\
(0.75)\end{array}$ & $\begin{array}{l}-1.59 \\
(1.16)\end{array}$ & $\begin{array}{c}1.67 \\
(0.92)\end{array}$ & $\begin{array}{c}0.02 \\
(0.49)\end{array}$ & $\begin{array}{c}0.11 \\
(0.81)\end{array}$ & $\begin{array}{c}1.40 \\
(0.51)\end{array}$ & $\begin{array}{c}-5.82 \\
(0.74)\end{array}$ & $\begin{array}{c}3.50 \\
(1.41)\end{array}$ \\
\hline 9. Miscellaneous & $\begin{array}{c}0.93 \\
(3.70)\end{array}$ & $\begin{array}{c}0.73 \\
(3.60)\end{array}$ & $\begin{array}{c}3.50 \\
(3.17)\end{array}$ & $\begin{array}{c}4.41 \\
(1.75)\end{array}$ & $\begin{array}{c}7.28 \\
(2.50)\end{array}$ & $\begin{array}{l}-1.27 \\
(1.99)\end{array}$ & $\begin{array}{c}-0.68 \\
(3.07)\end{array}$ & $\begin{array}{c}2.09 \\
(2.43)\end{array}$ & $\begin{array}{c}0.24 \\
(1.29)\end{array}$ & $\begin{array}{c}0.47 \\
(2.15)\end{array}$ & $\begin{array}{c}1.35 \\
(1.34)\end{array}$ & $\begin{array}{c}4.58 \\
(1.95)\end{array}$ & $\begin{array}{r}-14.06 \\
(3.74)\end{array}$ \\
\hline \multicolumn{14}{|c|}{ B. Symmetry-constrained } \\
\hline 1. Food & $\begin{array}{c}-5.73 \\
(4.72)\end{array}$ & $\begin{array}{r}-16.06 \\
(4.78)\end{array}$ & $\begin{array}{c}-4.84 \\
(4.28)\end{array}$ & $\begin{array}{l}-5.20 \\
(2.35)\end{array}$ & $\begin{array}{l}-12.04 \\
(2.81)\end{array}$ & $\begin{array}{c}2.95 \\
(0.86)\end{array}$ & $\begin{array}{c}4.84 \\
(1.90)\end{array}$ & $\begin{array}{l}-0.05 \\
(0.67)\end{array}$ & $\begin{array}{c}1.86 \\
(0.94)\end{array}$ & $\begin{array}{c}0.46 \\
(1.22)\end{array}$ & $\begin{array}{l}-2.01 \\
(1.07)\end{array}$ & $\begin{array}{l}-1.26 \\
(0.79)\end{array}$ & $\begin{array}{c}5.25 \\
(2.05)\end{array}$ \\
\hline 2. Clothing & $\begin{array}{c}-0.44 \\
(1.47)\end{array}$ & $\begin{array}{c}0.48 \\
(1.45)\end{array}$ & $\begin{array}{c}-0.99 \\
(1.30)\end{array}$ & $\begin{array}{c}0.01 \\
(0.71)\end{array}$ & & $\begin{array}{c}-2.86 \\
(0.72)\end{array}$ & $\begin{array}{c}0.81 \\
(0.96)\end{array}$ & $\begin{array}{c}-0.57 \\
(0.47)\end{array}$ & $\begin{array}{c}-1.43 \\
(0.43)\end{array}$ & $\begin{array}{c}1.02 \\
(0.66)\end{array}$ & $\begin{array}{l}-0.43 \\
(0.46)\end{array}$ & $\begin{array}{c}0.62 \\
(0.48)\end{array}$ & $\begin{array}{c}-0.09 \\
(1.11)\end{array}$ \\
\hline 3. Housing & $\begin{array}{c}0.27 \\
(3.84)\end{array}$ & $\begin{array}{l}13.40 \\
(3.87)\end{array}$ & $\begin{array}{c}2.82 \\
(3.48)\end{array}$ & $\begin{array}{c}0.67 \\
(1.91)\end{array}$ & & & $\begin{array}{r}-10.45 \\
(2.47)\end{array}$ & $\begin{array}{c}1.28 \\
(0.77)\end{array}$ & $\begin{array}{c}1.44 \\
(0.87)\end{array}$ & $\begin{array}{l}-0.70 \\
(1.23)\end{array}$ & $\begin{array}{c}3.19 \\
(0.98)\end{array}$ & $\begin{array}{c}-0.37 \\
(0.85)\end{array}$ & $\begin{array}{c}-0.04 \\
(2.07)\end{array}$ \\
\hline 4. Furnishings & $\begin{array}{c}-0.64 \\
(1.04)\end{array}$ & $\begin{array}{c}1.86 \\
(1.02)\end{array}$ & $\begin{array}{l}1.87 \\
(0.90)\end{array}$ & $\begin{array}{c}0.63 \\
(0.50)\end{array}$ & & & & $\begin{array}{l}-4.35 \\
(0.66)\end{array}$ & $\begin{array}{c}1.66 \\
(0.34)\end{array}$ & $\begin{array}{c}0.76 \\
(0.55)\end{array}$ & $\begin{array}{l}-0.70 \\
(0.36)\end{array}$ & $\begin{array}{c}0.44 \\
(0.45)\end{array}$ & $\begin{array}{c}1.53 \\
(0.94)\end{array}$ \\
\hline 5. Health & $\begin{array}{c}5.83 \\
(1.84)\end{array}$ & $\begin{array}{c}0.69 \\
(1.84)\end{array}$ & $\begin{array}{c}0.43 \\
(1.65)\end{array}$ & $\begin{array}{c}-0.11 \\
(0.91)\end{array}$ & & & & & $\begin{array}{l}-6.77 \\
(0.60)\end{array}$ & $\begin{array}{c}1.26 \\
(0.59)\end{array}$ & $\begin{array}{l}-0.09 \\
(0.49)\end{array}$ & $\begin{array}{c}0.53 \\
(0.40)\end{array}$ & $\begin{array}{c}1.55 \\
(0.99)\end{array}$ \\
\hline 6. Education & $\begin{array}{c}0.40 \\
(2.15)\end{array}$ & $\begin{array}{l}-0.35 \\
(2.14)\end{array}$ & $\begin{array}{c}-0.63 \\
(1.91)\end{array}$ & $\begin{array}{c}0.04 \\
(1.05)\end{array}$ & & & & & & $\begin{array}{c}-6.93 \\
(1.24)\end{array}$ & $\begin{array}{l}-0.08 \\
(0.66)\end{array}$ & $\begin{array}{c}1.55 \\
(0.61)\end{array}$ & $\begin{array}{c}2.65 \\
(1.46)\end{array}$ \\
\hline 7. Restaurants & $\begin{array}{c}-2.96 \\
(2.41)\end{array}$ & $\begin{array}{l}-1.55 \\
(2.40)\end{array}$ & $\begin{array}{l}-2.09 \\
(2.15)\end{array}$ & $\begin{array}{c}0.27 \\
(1.18)\end{array}$ & & & & & & & $\begin{array}{c}-2.96 \\
(0.79)\end{array}$ & $\begin{array}{c}1.48 \\
(0.44)\end{array}$ & $\begin{array}{c}1.61 \\
(1.13)\end{array}$ \\
\hline 8. Recreation & $\begin{array}{c}1.18 \\
(1.40)\end{array}$ & $\begin{array}{c}1.08 \\
(1.37)\end{array}$ & $\begin{array}{c}0.43 \\
(1.22)\end{array}$ & $\begin{array}{c}-0.73 \\
(0.67)\end{array}$ & & & & & & & & $\begin{array}{r}-6.45 \\
(0.64)\end{array}$ & $\begin{array}{r}3.46 \\
(1.06)\end{array}$ \\
\hline 9. Miscellaneous & $\begin{array}{c}2.10 \\
(3.63)\end{array}$ & $\begin{array}{c}0.44 \\
(3.58)\end{array}$ & $\begin{array}{c}3.01 \\
(3.20)\end{array}$ & $\begin{array}{c}4.42 \\
(1.76)\end{array}$ & & & & & & & & & $\begin{array}{l}-\mathbf{1 5 . 9 1} \\
(3.37)\end{array}$ \\
\hline \multicolumn{14}{|c|}{ C. No price effects } \\
\hline & Incon & coefficie & & & $\beta_{1}$ & $\beta_{2}$ & $\beta_{3}$ & $\beta_{4}$ & $\beta_{5}$ & $\beta_{6}$ & $\beta_{7}$ & $\beta_{8}$ & $\beta_{9}$ \\
\hline & & Q1 & & & $\begin{array}{l}-6.15 \\
(4.64)\end{array}$ & $\begin{array}{c}0.06 \\
(1.44)\end{array}$ & $\begin{array}{c}2.53 \\
(3.73)\end{array}$ & $\begin{array}{c}-0.39 \\
(1.10)\end{array}$ & $\begin{array}{c}7.96 \\
(2.25)\end{array}$ & $\begin{array}{c}1.04 \\
(2.15)\end{array}$ & $\begin{array}{l}-3.92 \\
(2.25)\end{array}$ & $\begin{array}{c}-1.77 \\
(1.52)\end{array}$ & $\begin{array}{c}0.64 \\
(3.48)\end{array}$ \\
\hline & & Q2 & & & $\begin{array}{l}-15.67 \\
(4.96)\end{array}$ & $\begin{array}{c}0.50 \\
(1.54)\end{array}$ & $\begin{array}{l}13.52 \\
(3.99)\end{array}$ & $\begin{array}{c}3.04 \\
(1.18)\end{array}$ & $\begin{array}{c}1.19 \\
(2.40)\end{array}$ & $\begin{array}{l}-1.37 \\
(2.30)\end{array}$ & $\begin{array}{l}-1.44 \\
(2.41)\end{array}$ & $\begin{array}{c}-0.34 \\
(1.63)\end{array}$ & $\begin{array}{c}0.56 \\
(3.72)\end{array}$ \\
\hline & & Q3 & & & $\begin{array}{l}-3.60 \\
(4.45)\end{array}$ & $\begin{array}{l}-1.27 \\
(1.38)\end{array}$ & $\begin{array}{c}0.95 \\
(3.58)\end{array}$ & $\begin{array}{c}1.40 \\
(1.06)\end{array}$ & $\begin{array}{c}1.75 \\
(2.16)\end{array}$ & $\begin{array}{l}-1.64 \\
(2.07)\end{array}$ & $\begin{array}{l}-1.78 \\
(2.16)\end{array}$ & $\begin{array}{c}1.37 \\
(1.46)\end{array}$ & $\begin{array}{c}2.82 \\
(3.34)\end{array}$ \\
\hline & & Q4 & & & $\begin{array}{l}-5.34 \\
(2.45)\end{array}$ & $\begin{array}{c}0.06 \\
(0.76)\end{array}$ & $\begin{array}{c}0.18 \\
(1.97)\end{array}$ & $\begin{array}{c}0.01 \\
(0.58)\end{array}$ & $\begin{array}{c}0.95 \\
(1.18)\end{array}$ & $\begin{array}{l}-0.26 \\
(1.14)\end{array}$ & $\begin{array}{c}0.07 \\
(1.19)\end{array}$ & $\begin{array}{c}0.11 \\
(0.80)\end{array}$ & $\begin{array}{c}4.23 \\
(1.83)\end{array}$ \\
\hline
\end{tabular}

Note: This table presents three sets of estimates of model (A7.1) with quartile-specific income coefficients. Common intercepts are included for all quartiles, but these are omitted from this table. All entries are multiplied by 100. Own-price coefficients and their standard errors are emboldened. Standard errors, obtained from 1,000 bootstrap replications, in parentheses. 
A-28

Table A7.3. Demand Equations, First Income Quartile

\begin{tabular}{|c|c|c|c|c|c|c|c|c|c|c|}
\hline \multirow{2}{*}{$\begin{array}{c}\text { Commodity } i \\
\text { (1) }\end{array}$} & \multirow{2}{*}{$\begin{array}{c}\text { Income } \\
\text { coefficient } \\
\beta_{i} \\
(2) \\
\end{array}$} & \multicolumn{9}{|c|}{ Price coefficients } \\
\hline & & $\begin{array}{l}\pi_{1 j} \\
(3)\end{array}$ & $\begin{array}{r}\pi_{2 j} \\
(4) \\
\end{array}$ & $\begin{array}{r}\pi_{3 j} \\
(5) \\
\end{array}$ & $\begin{array}{c}\pi_{4 j} \\
(6) \\
\end{array}$ & $\begin{array}{l}\pi_{5 j} \\
(7)\end{array}$ & $\begin{array}{r}\pi_{6 j} \\
(8) \\
\end{array}$ & $\begin{array}{r}\pi_{7 j} \\
(9) \\
\end{array}$ & $\begin{array}{l}\pi_{8 j} \\
(10)\end{array}$ & $\begin{array}{l}\pi_{9 j} \\
(11)\end{array}$ \\
\hline \multicolumn{11}{|c|}{ A. Homogeneity-constrained } \\
\hline 1. Food & $\begin{array}{l}-4.08 \\
(7.78)\end{array}$ & $\begin{array}{l}-13.74 \\
(7.12)\end{array}$ & $\begin{array}{c}4.49 \\
(10.69)\end{array}$ & $\begin{array}{c}9.98 \\
(16.58)\end{array}$ & $\begin{array}{c}0.12 \\
(10.32)\end{array}$ & $\begin{array}{l}-0.55 \\
(4.56)\end{array}$ & $\begin{array}{c}4.46 \\
(8.03)\end{array}$ & $\begin{array}{c}0.22 \\
(6.16)\end{array}$ & $\begin{array}{l}-2.95 \\
(7.57)\end{array}$ & $\begin{array}{c}-2.03 \\
(15.63)\end{array}$ \\
\hline 2. Clothing & $\begin{array}{l}-0.14 \\
(2.34)\end{array}$ & $\begin{array}{l}-0.71 \\
(2.14)\end{array}$ & $\begin{array}{l}-5.65 \\
(3.22)\end{array}$ & $\begin{array}{c}3.53 \\
(4.99)\end{array}$ & $\begin{array}{l}1.01 \\
(3.11)\end{array}$ & $\begin{array}{l}-0.16 \\
(1.37)\end{array}$ & $\begin{array}{l}1.25 \\
(2.42)\end{array}$ & $\begin{array}{l}-1.74 \\
(1.86)\end{array}$ & $\begin{array}{l}-0.52 \\
(2.28)\end{array}$ & $\begin{array}{c}2.98 \\
(4.70)\end{array}$ \\
\hline 3. Housing & $\begin{array}{l}-8.43 \\
(6.06)\end{array}$ & $\begin{array}{c}4.53 \\
(5.55)\end{array}$ & $\begin{array}{l}-10.7 \\
(8.33)\end{array}$ & $\begin{array}{l}-37.21 \\
(12.91)\end{array}$ & $\begin{array}{c}3.06 \\
(8.04)\end{array}$ & $\begin{array}{l}12.69 \\
(3.55)\end{array}$ & $\begin{array}{c}2.42 \\
(6.26)\end{array}$ & $\begin{array}{c}2.5 \\
(4.80)\end{array}$ & $\begin{array}{l}-2.51 \\
(5.90)\end{array}$ & $\begin{array}{c}25.22 \\
(12.17)\end{array}$ \\
\hline 4. Furnishings & $\begin{array}{c}-0.1 \\
(1.73)\end{array}$ & $\begin{array}{c}0.31 \\
(1.58)\end{array}$ & $\begin{array}{l}-3.03 \\
(2.38)\end{array}$ & $\begin{array}{c}5.76 \\
(3.69)\end{array}$ & $\begin{array}{l}-5.32 \\
(2.30)\end{array}$ & $\begin{array}{c}0.45 \\
(1.01)\end{array}$ & $\begin{array}{c}2.57 \\
(1.79)\end{array}$ & $\begin{array}{l}-1.85 \\
(1.37)\end{array}$ & $\begin{array}{c}0.83 \\
(1.68)\end{array}$ & $\begin{array}{c}0.27 \\
(3.48)\end{array}$ \\
\hline 5. Health & $\begin{array}{c}3.71 \\
(2.73)\end{array}$ & $\begin{array}{l}-1.48 \\
(2.50)\end{array}$ & $\begin{array}{c}0.87 \\
(3.76)\end{array}$ & $\begin{array}{c}1.68 \\
(5.82)\end{array}$ & $\begin{array}{c}0.37 \\
(3.63)\end{array}$ & $\begin{array}{l}-10.88 \\
(1.60)\end{array}$ & $\begin{array}{c}5.41 \\
(2.82)\end{array}$ & $\begin{array}{c}3.91 \\
(2.17)\end{array}$ & $\begin{array}{c}-1.4 \\
(2.66)\end{array}$ & $\begin{array}{c}1.51 \\
(5.49)\end{array}$ \\
\hline 6. Education & $\begin{array}{l}-1.15 \\
(3.45)\end{array}$ & $\begin{array}{c}5.37 \\
(3.15)\end{array}$ & $\begin{array}{c}2.83 \\
(4.74)\end{array}$ & $\begin{array}{c}-1.2 \\
(7.34)\end{array}$ & $\begin{array}{l}-5.66 \\
(4.57)\end{array}$ & $\begin{array}{l}-1.99 \\
(2.02)\end{array}$ & $\begin{array}{l}-10.01 \\
(3.56)\end{array}$ & $\begin{array}{l}-0.55 \\
(2.73)\end{array}$ & $\begin{array}{c}2.55 \\
(3.36)\end{array}$ & $\begin{array}{c}8.66 \\
(6.92)\end{array}$ \\
\hline 7. Restaurants & $\begin{array}{c}1.87 \\
(4.03)\end{array}$ & $\begin{array}{c}0 \\
(3.68)\end{array}$ & $\begin{array}{l}11.43 \\
(5.53)\end{array}$ & $\begin{array}{c}0.3 \\
(8.58)\end{array}$ & $\begin{array}{c}3.19 \\
(5.34)\end{array}$ & $\begin{array}{c}0.21 \\
(2.36)\end{array}$ & $\begin{array}{l}-7.76 \\
(4.16)\end{array}$ & $\begin{array}{l}-6.75 \\
(3.19)\end{array}$ & $\begin{array}{c}7.54 \\
(3.92)\end{array}$ & $\begin{array}{l}-8.15 \\
(8.09)\end{array}$ \\
\hline 8. Recreation & $\begin{array}{c}4.04 \\
(2.05)\end{array}$ & $\begin{array}{c}0.83 \\
(1.88)\end{array}$ & $\begin{array}{c}5.7 \\
(2.82)\end{array}$ & $\begin{array}{l}-0.52 \\
(4.37)\end{array}$ & $\begin{array}{c}3.14 \\
(2.72)\end{array}$ & $\begin{array}{l}-0.67 \\
(1.20)\end{array}$ & $\begin{array}{l}-4.45 \\
(2.12)\end{array}$ & $\begin{array}{c}3.2 \\
(1.63)\end{array}$ & $\begin{array}{l}-9.15 \\
(2.00)\end{array}$ & $\begin{array}{c}1.93 \\
(4.12)\end{array}$ \\
\hline 9. Miscellaneous & $\begin{array}{c}4.29 \\
(5.97)\end{array}$ & $\begin{array}{c}4.88 \\
(5.46)\end{array}$ & $\begin{array}{l}-5.93 \\
(8.21)\end{array}$ & $\begin{array}{c}17.68 \\
(12.72)\end{array}$ & $\begin{array}{c}0.09 \\
(7.92)\end{array}$ & $\begin{array}{c}0.91 \\
(3.50)\end{array}$ & $\begin{array}{c}6.1 \\
(6.17)\end{array}$ & $\begin{array}{c}1.05 \\
(4.73)\end{array}$ & $\begin{array}{c}5.62 \\
(5.81)\end{array}$ & $\begin{array}{l}-30.38 \\
(11.99)\end{array}$ \\
\hline \multicolumn{11}{|c|}{ B. Symmetry-constrained } \\
\hline 1. Food & $\begin{array}{l}-6.86 \\
(6.10)\end{array}$ & $\begin{array}{c}-14 \\
(7.17)\end{array}$ & $\begin{array}{c}0.11 \\
(2.12)\end{array}$ & $\begin{array}{l}10.29 \\
(5.03)\end{array}$ & $\begin{array}{c}1.08 \\
(1.52)\end{array}$ & $\begin{array}{c}-2.3 \\
(2.23)\end{array}$ & $\begin{array}{c}3.65 \\
(2.85)\end{array}$ & $\begin{array}{l}-2.41 \\
(3.09)\end{array}$ & $\begin{array}{l}-0.39 \\
(1.80)\end{array}$ & $\begin{array}{c}3.98 \\
(5.13)\end{array}$ \\
\hline 2. Clothing & $\begin{array}{l}-1.19 \\
(2.30)\end{array}$ & & $\begin{array}{l}-1.65 \\
(2.83)\end{array}$ & $\begin{array}{c}3.12 \\
(3.52)\end{array}$ & $\begin{array}{c}-0.4 \\
(1.70)\end{array}$ & $\begin{array}{l}-0.69 \\
(1.22)\end{array}$ & $\begin{array}{c}0 \\
(1.95)\end{array}$ & $\begin{array}{c}0.52 \\
(1.67)\end{array}$ & $\begin{array}{c}1.96 \\
(1.60)\end{array}$ & $\begin{array}{l}-2.95 \\
(3.65)\end{array}$ \\
\hline 3. Housing & $\begin{array}{l}-12.67 \\
(5.30)\end{array}$ & & & $\begin{array}{l}-48.8 \\
(8.49)\end{array}$ & $\begin{array}{c}3.71 \\
(3.16)\end{array}$ & $\begin{array}{c}7.08 \\
(2.49)\end{array}$ & $\begin{array}{l}-4.83 \\
(3.69)\end{array}$ & $\begin{array}{c}8.36 \\
(3.40)\end{array}$ & $\begin{array}{c}3.58 \\
(2.68)\end{array}$ & $\begin{array}{l}17.49 \\
(6.59)\end{array}$ \\
\hline 4. Furnishings & $\begin{array}{l}-0.84 \\
(1.65)\end{array}$ & & & & $\begin{array}{l}-5.22 \\
(2.07)\end{array}$ & $\begin{array}{c}0.18 \\
(0.93)\end{array}$ & $\begin{array}{c}0.82 \\
(1.52)\end{array}$ & $\begin{array}{l}-0.57 \\
(1.25)\end{array}$ & $\begin{array}{c}1.97 \\
(1.31)\end{array}$ & $\begin{array}{l}-1.57 \\
(2.88)\end{array}$ \\
\hline 5. Health & $\begin{array}{c}4.02 \\
(2.37)\end{array}$ & & & & & $\begin{array}{c}-11.16 \\
(1.56)\end{array}$ & $\begin{array}{c}2.42 \\
(1.50)\end{array}$ & $\begin{array}{c}2.3 \\
(1.52)\end{array}$ & $\begin{array}{l}-0.34 \\
(1.06)\end{array}$ & $\begin{array}{c}2.53 \\
(2.69)\end{array}$ \\
\hline 6. Education & $\begin{array}{c}2.15 \\
(3.02)\end{array}$ & & & & & & $\begin{array}{l}-9.04 \\
(2.98)\end{array}$ & $\begin{array}{l}-1.54 \\
(2.09)\end{array}$ & $\begin{array}{l}-2.06 \\
(1.56)\end{array}$ & $\begin{array}{l}10.59 \\
(3.90)\end{array}$ \\
\hline 7. Restaurants & $\begin{array}{c}2.87 \\
(3.68)\end{array}$ & & & & & & & $\begin{array}{l}-9.27 \\
(2.97)\end{array}$ & $\begin{array}{c}2.34 \\
(1.39)\end{array}$ & $\begin{array}{c}0.28 \\
(3.80)\end{array}$ \\
\hline 8. Recreation & $\begin{array}{c}4.36 \\
(2.08)\end{array}$ & & & & & & & & $\begin{array}{l}-10.4 \\
(1.80)\end{array}$ & $\begin{array}{c}3.34 \\
(2.96)\end{array}$ \\
\hline 9. Miscellaneous & $\begin{array}{c}8.16 \\
(5.45)\end{array}$ & & & & & & & & & $\begin{array}{r}-33.69 \\
(9.60)\end{array}$ \\
\hline \multicolumn{11}{|c|}{ C. No price effects } \\
\hline 1. Food & $\begin{array}{l}-6.55 \\
(4.69)\end{array}$ & & & & & & & & & \\
\hline 2. Clothing & $\begin{array}{c}0.21 \\
(1.46)\end{array}$ & & & & & & & & & \\
\hline 3. Housing & $\begin{array}{c}2.44 \\
(3.80)\end{array}$ & & & & & & & & & \\
\hline 4. Furnishings & $\begin{array}{l}-0.38 \\
(1.12)\end{array}$ & & & & & & & & & \\
\hline 5. Health & $\begin{array}{c}7.93 \\
(2.29)\end{array}$ & & & & & & & & & \\
\hline 6. Education & $\begin{array}{c}1.21 \\
(2.19)\end{array}$ & & & & & & & & & \\
\hline 7. Restaurants & $\begin{array}{l}-3.89 \\
(2.29)\end{array}$ & & & & & & & & & \\
\hline 8. Recreation & $\begin{array}{c}-1.7 \\
(1.55)\end{array}$ & & & & & & & & & \\
\hline 9. Miscellaneous & $\begin{array}{c}0.73 \\
(3.54)\end{array}$ & & & & & & & & & \\
\hline
\end{tabular}

Note: This table presents three sets of estimates of model (A7.1) for the countries in the highest income quartile. Intercepts are included in each equation, but these are omitted from this table. All entries are multiplied by 100 . Own-price coefficients and their standard errors are emboldened. Standard errors, obtained from 1,000 bootstrap replications, in parentheses. 
A-29

Table A7.4. Demand Equations, Second Income Quartile

\begin{tabular}{|c|c|c|c|c|c|c|c|c|c|c|}
\hline \multirow{2}{*}{$\begin{array}{c}\text { Commodity } i \\
\text { (1) }\end{array}$} & \multirow{2}{*}{$\begin{array}{c}\text { Income } \\
\text { coefficient } \\
\beta_{i} \\
(2)\end{array}$} & \multicolumn{9}{|c|}{ Price coefficients } \\
\hline & & $\begin{array}{l}\pi_{1 j} \\
(3)\end{array}$ & $\begin{array}{l}\pi_{2 j} \\
(4)\end{array}$ & $\begin{array}{l}\pi_{3 j} \\
(5)\end{array}$ & $\begin{array}{l}\pi_{4 j} \\
(6)\end{array}$ & $\begin{array}{l}\pi_{5 j} \\
(7)\end{array}$ & $\begin{array}{l}\pi_{6 j} \\
(8)\end{array}$ & $\begin{array}{l}\pi_{7 j} \\
(9)\end{array}$ & $\begin{array}{c}\pi_{8 j} \\
(10)\end{array}$ & $\begin{array}{l}\pi_{9 j} \\
(11)\end{array}$ \\
\hline \multicolumn{11}{|c|}{ A. Homogeneity-constrained } \\
\hline 1. Food & $\begin{array}{l}-15.17 \\
(5.28)\end{array}$ & $\begin{array}{c}-8.43 \\
(8.91)\end{array}$ & $\begin{array}{c}8.87 \\
(5.49)\end{array}$ & $\begin{array}{l}12.25 \\
(8.57)\end{array}$ & $\begin{array}{c}-2.32 \\
(6.81)\end{array}$ & $\begin{array}{l}-1.24 \\
(3.59)\end{array}$ & $\begin{array}{c}2.94 \\
(6.87)\end{array}$ & $\begin{array}{c}-4.1 \\
(4.05)\end{array}$ & $\begin{array}{c}-3.38 \\
(4.94)\end{array}$ & $\begin{array}{c}-4.59 \\
(10.26)\end{array}$ \\
\hline 2. Clothing & $\begin{array}{l}-0.32 \\
(1.59)\end{array}$ & $\begin{array}{c}0.83 \\
(2.68)\end{array}$ & $\begin{array}{c}-2.17 \\
(1.65)\end{array}$ & $\begin{array}{c}0.15 \\
(2.58)\end{array}$ & $\begin{array}{l}-3.68 \\
(2.05)\end{array}$ & $\begin{array}{c}0.89 \\
(1.08)\end{array}$ & $\begin{array}{c}3.07 \\
(2.07)\end{array}$ & $\begin{array}{l}-1.21 \\
(1.22)\end{array}$ & $\begin{array}{l}-1.11 \\
(1.49)\end{array}$ & $\begin{array}{c}3.24 \\
(3.09)\end{array}$ \\
\hline 3. Housing & $\begin{array}{l}13.63 \\
(4.12)\end{array}$ & $\begin{array}{c}1.93 \\
(6.94)\end{array}$ & $\begin{array}{l}-8.17 \\
(4.28)\end{array}$ & $\begin{array}{l}-4.35 \\
(6.67)\end{array}$ & $\begin{array}{c}7.01 \\
(5.31)\end{array}$ & $\begin{array}{c}1.08 \\
(2.80)\end{array}$ & $\begin{array}{c}3.6 \\
(5.35)\end{array}$ & $\begin{array}{c}4.29 \\
(3.16)\end{array}$ & $\begin{array}{c}3.2 \\
(3.85)\end{array}$ & $\begin{array}{c}-8.59 \\
(7.99)\end{array}$ \\
\hline 4. Furnishings & $\begin{array}{c}1.48 \\
(1.18)\end{array}$ & $\begin{array}{c}0.15 \\
(1.98)\end{array}$ & $\begin{array}{c}-0.24 \\
(1.22)\end{array}$ & $\begin{array}{c}-0.56 \\
(1.91)\end{array}$ & $\begin{array}{l}-6.37 \\
(1.52)\end{array}$ & $\begin{array}{c}1.85 \\
(0.80)\end{array}$ & $\begin{array}{c}2.21 \\
(1.53)\end{array}$ & $\begin{array}{c}0 \\
(0.90)\end{array}$ & $\begin{array}{l}-1.74 \\
(1.10)\end{array}$ & $\begin{array}{c}4.71 \\
(2.28)\end{array}$ \\
\hline 5. Health & $\begin{array}{l}-2.11 \\
(1.86)\end{array}$ & $\begin{array}{c}-0.72 \\
(3.13)\end{array}$ & $\begin{array}{c}2.41 \\
(1.93)\end{array}$ & $\begin{array}{l}-2.29 \\
(3.01)\end{array}$ & $\begin{array}{c}-0.09 \\
(2.39)\end{array}$ & $\begin{array}{l}-8.16 \\
(1.26)\end{array}$ & $\begin{array}{c}5.4 \\
(2.41)\end{array}$ & $\begin{array}{c}-1.1 \\
(1.42)\end{array}$ & $\begin{array}{c}3.57 \\
(1.74)\end{array}$ & $\begin{array}{c}0.99 \\
(3.60)\end{array}$ \\
\hline 6. Education & $\begin{array}{l}-2.33 \\
(2.34)\end{array}$ & $\begin{array}{c}-5.62 \\
(3.95)\end{array}$ & $\begin{array}{c}2.83 \\
(2.43)\end{array}$ & $\begin{array}{c}-8.08 \\
(3.80)\end{array}$ & $\begin{array}{c}0.44 \\
(3.02)\end{array}$ & $\begin{array}{c}2.69 \\
(1.59)\end{array}$ & $\begin{array}{l}-7.64 \\
(3.04)\end{array}$ & $\begin{array}{c}-2.12 \\
(1.80)\end{array}$ & $\begin{array}{c}2.84 \\
(2.19)\end{array}$ & $\begin{array}{l}14.66 \\
(4.54)\end{array}$ \\
\hline 7. Restaurants & $\begin{array}{l}-0.01 \\
(2.74)\end{array}$ & $\begin{array}{c}-0.69 \\
(4.61)\end{array}$ & $\begin{array}{l}-1.25 \\
(2.84)\end{array}$ & $\begin{array}{c}-2.18 \\
(4.43)\end{array}$ & $\begin{array}{c}1.12 \\
(3.53)\end{array}$ & $\begin{array}{c}0.3 \\
(1.86)\end{array}$ & $\begin{array}{l}-3.41 \\
(3.55)\end{array}$ & $\begin{array}{l}-3.23 \\
(2.10)\end{array}$ & $\begin{array}{l}-1.55 \\
(2.56)\end{array}$ & $\begin{array}{l}10.89 \\
(5.31)\end{array}$ \\
\hline 8. Recreation & $\begin{array}{c}2.48 \\
(1.39)\end{array}$ & $\begin{array}{c}-0.62 \\
(2.35)\end{array}$ & $\begin{array}{c}1.95 \\
(1.45)\end{array}$ & $\begin{array}{c}1.7 \\
(2.26)\end{array}$ & $\begin{array}{c}-1.14 \\
(1.80)\end{array}$ & $\begin{array}{c}1.3 \\
(0.95)\end{array}$ & $\begin{array}{c}-1.5 \\
(1.81)\end{array}$ & $\begin{array}{c}1.39 \\
(1.07)\end{array}$ & $\begin{array}{l}-8.32 \\
(1.30)\end{array}$ & $\begin{array}{c}5.22 \\
(2.71)\end{array}$ \\
\hline 9. Miscellaneous & $\begin{array}{c}2.35 \\
(4.06)\end{array}$ & $\begin{array}{r}13.17 \\
(6.84)\end{array}$ & $\begin{array}{c}-4.23 \\
(4.21)\end{array}$ & $\begin{array}{c}3.37 \\
(6.58)\end{array}$ & $\begin{array}{c}5.03 \\
(5.23)\end{array}$ & $\begin{array}{c}1.3 \\
(2.76)\end{array}$ & $\begin{array}{l}-4.67 \\
(5.27)\end{array}$ & $\begin{array}{c}6.08 \\
(3.11)\end{array}$ & $\begin{array}{c}6.48 \\
(3.79)\end{array}$ & $\begin{array}{l}-26.54 \\
(7.87)\end{array}$ \\
\hline \multicolumn{11}{|c|}{ B. Symmetry-constrained } \\
\hline 1. Food & $\begin{array}{l}-14.23 \\
(5.44)\end{array}$ & $\begin{array}{c}-11.7 \\
(7.97)\end{array}$ & $\begin{array}{c}2.23 \\
(2.15)\end{array}$ & $\begin{array}{l}11.89 \\
(4.80)\end{array}$ & $\begin{array}{c}0.53 \\
(1.81)\end{array}$ & $\begin{array}{l}-1.08 \\
(2.29)\end{array}$ & $\begin{array}{l}-3.05 \\
(3.31)\end{array}$ & $\begin{array}{l}-3.19 \\
(2.94)\end{array}$ & $\begin{array}{l}-3.28 \\
(1.97)\end{array}$ & $\begin{array}{c}7.65 \\
(5.75)\end{array}$ \\
\hline 2. Clothing & $\begin{array}{c}0.43 \\
(1.61)\end{array}$ & & $\begin{array}{c}-2.14 \\
(1.34)\end{array}$ & $\begin{array}{c}0.59 \\
(1.96)\end{array}$ & $\begin{array}{l}-1.11 \\
(0.96)\end{array}$ & $\begin{array}{c}0.34 \\
(0.87)\end{array}$ & $\begin{array}{c}1.65 \\
(1.45)\end{array}$ & $\begin{array}{l}-1.15 \\
(1.04)\end{array}$ & $\begin{array}{c}0.45 \\
(0.89)\end{array}$ & $\begin{array}{c}-0.87 \\
(2.21)\end{array}$ \\
\hline 3. Housing & $\begin{array}{l}14.38 \\
(4.16)\end{array}$ & & & $\begin{array}{c}-6.28 \\
(5.67)\end{array}$ & $\begin{array}{c}0.62 \\
(1.68)\end{array}$ & $\begin{array}{l}-0.91 \\
(1.91)\end{array}$ & $\begin{array}{l}-4.94 \\
(3.03)\end{array}$ & $\begin{array}{c}2.97 \\
(2.40)\end{array}$ & $\begin{array}{c}2.19 \\
(1.77)\end{array}$ & $\begin{array}{l}-6.12 \\
(4.79)\end{array}$ \\
\hline 4. Furnishings & $\begin{array}{c}1.92 \\
(1.17)\end{array}$ & & & & $\begin{array}{c}-5.34 \\
(1.37)\end{array}$ & $\begin{array}{c}1.6 \\
(0.73)\end{array}$ & $\begin{array}{c}1.39 \\
(1.29)\end{array}$ & $\begin{array}{c}0.04 \\
(0.84)\end{array}$ & $\begin{array}{l}-1.14 \\
(0.89)\end{array}$ & $\begin{array}{c}3.42 \\
(1.96)\end{array}$ \\
\hline 5. Health & $\begin{array}{l}-0.84 \\
(1.88)\end{array}$ & & & & & $\begin{array}{l}-7.75 \\
(1.28)\end{array}$ & $\begin{array}{c}3.92 \\
(1.34)\end{array}$ & $\begin{array}{l}-0.19 \\
(1.13)\end{array}$ & $\begin{array}{c}2.19 \\
(0.79)\end{array}$ & $\begin{array}{c}1.87 \\
(2.18)\end{array}$ \\
\hline 6. Education & $\begin{array}{l}-0.87 \\
(2.42)\end{array}$ & & & & & & $\begin{array}{l}-7.61 \\
(3.08)\end{array}$ & $\begin{array}{l}-1.27 \\
(1.63)\end{array}$ & $\begin{array}{c}1.97 \\
(1.32)\end{array}$ & $\begin{array}{c}7.95 \\
(3.39)\end{array}$ \\
\hline 7. Restaurants & $\begin{array}{l}-0.92 \\
(2.70)\end{array}$ & & & & & & & $\begin{array}{l}-3.85 \\
(2.03)\end{array}$ & $\begin{array}{c}0.85 \\
(0.96)\end{array}$ & $\begin{array}{c}5.79 \\
(2.78)\end{array}$ \\
\hline 8. Recreation & $\begin{array}{c}1.88 \\
(1.42)\end{array}$ & & & & & & & & $\begin{array}{l}-8.51 \\
(1.17)\end{array}$ & $\begin{array}{c}5.28 \\
(2.15)\end{array}$ \\
\hline 9. Miscellaneous & $\begin{array}{l}-1.74 \\
(4.16)\end{array}$ & & & & & & & & & $\begin{array}{l}-24.99 \\
(7.56)\end{array}$ \\
\hline \multicolumn{11}{|c|}{ price effects } \\
\hline 1. Food & $\begin{array}{c}-16.79 \\
(5.08)\end{array}$ & & & & & & & & & \\
\hline 2. Clothing & $\begin{array}{c}0.72 \\
(1.58)\end{array}$ & & & & & & & & & \\
\hline 3. Housing & $\begin{array}{l}14.14 \\
(4.11)\end{array}$ & & & & & & & & & \\
\hline 4. Furnishings & $\begin{array}{c}3.21 \\
(1.21)\end{array}$ & & & & & & & & & \\
\hline 5. Health & $\begin{array}{c}1.33 \\
(2.48)\end{array}$ & & & & & & & & & \\
\hline 6. Education & $\begin{array}{c}-1.5 \\
(2.37)\end{array}$ & & & & & & & & & \\
\hline 7. Restaurants & $\begin{array}{l}-1.37 \\
(2.48)\end{array}$ & & & & & & & & & \\
\hline 8. Recreation & $\begin{array}{l}-0.35 \\
(1.68)\end{array}$ & & & & & & & & & \\
\hline 9. Miscellaneous & $\begin{array}{c}0.61 \\
(3.83)\end{array}$ & & & & & & & & & \\
\hline
\end{tabular}


A-30

Table A7.5. Demand Equations, Third Income Quartile

\begin{tabular}{|c|c|c|c|c|c|c|c|c|c|c|}
\hline \multirow{2}{*}{$\begin{array}{c}\text { Commodity } i \\
\text { (1) }\end{array}$} & \multirow{2}{*}{$\begin{array}{c}\text { Income } \\
\text { coefficient } \\
\beta_{i} \\
(2)\end{array}$} & \multicolumn{9}{|c|}{ Price coefficients } \\
\hline & & $\begin{array}{l}\pi_{1 j} \\
(3)\end{array}$ & $\begin{array}{l}\pi_{2 j} \\
(4)\end{array}$ & $\begin{array}{l}\pi_{3 j} \\
(5) \\
\end{array}$ & $\begin{array}{l}\pi_{4 j} \\
(6)\end{array}$ & $\begin{array}{l}\pi_{5 j} \\
(7)\end{array}$ & $\begin{array}{r}\pi_{6 j} \\
(8)\end{array}$ & $\begin{array}{l}\pi_{7 j} \\
(9)\end{array}$ & $\begin{array}{c}\pi_{8 j} \\
(10)\end{array}$ & $\begin{array}{l}\pi_{9 j} \\
(11)\end{array}$ \\
\hline \multicolumn{11}{|c|}{ A. Homogeneity-constrained } \\
\hline 1. Food & $\begin{array}{l}-6.47 \\
(4.27)\end{array}$ & $\begin{array}{l}-1.01 \\
(8.79)\end{array}$ & $\begin{array}{c}4.81 \\
(4.78)\end{array}$ & $\begin{array}{r}12.63 \\
(8.37)\end{array}$ & $\begin{array}{c}10.56 \\
(6.80)\end{array}$ & $\begin{array}{c}9.23 \\
(3.34)\end{array}$ & $\begin{array}{c}9.7 \\
(5.65)\end{array}$ & $\begin{array}{c}-7.57 \\
(3.84)\end{array}$ & $\begin{array}{c}6.14 \\
(5.37)\end{array}$ & $\begin{array}{c}-44.5 \\
(11.09)\end{array}$ \\
\hline 2. Clothing & $\begin{array}{l}-0.91 \\
(1.29)\end{array}$ & $\begin{array}{c}2.97 \\
(2.65)\end{array}$ & $\begin{array}{c}-5.23 \\
(1.44)\end{array}$ & $\begin{array}{c}2.65 \\
(2.52)\end{array}$ & $\begin{array}{c}-4.05 \\
(2.05)\end{array}$ & $\begin{array}{c}-4.96 \\
(1.01)\end{array}$ & $\begin{array}{c}-0.96 \\
(1.70)\end{array}$ & $\begin{array}{c}1.17 \\
(1.16)\end{array}$ & $\begin{array}{c}-0.51 \\
(1.62)\end{array}$ & $\begin{array}{c}8.93 \\
(3.34)\end{array}$ \\
\hline 3. Housing & $\begin{array}{c}2.93 \\
(3.33)\end{array}$ & $\begin{array}{l}-5.65 \\
(6.85)\end{array}$ & $\begin{array}{c}-7.37 \\
(3.73)\end{array}$ & $\begin{array}{c}-3.06 \\
(6.52)\end{array}$ & $\begin{array}{c}1.28 \\
(5.30)\end{array}$ & $\begin{array}{c}-0.65 \\
(2.61)\end{array}$ & $\begin{array}{l}-1.44 \\
(4.40)\end{array}$ & $\begin{array}{c}4.31 \\
(2.99)\end{array}$ & $\begin{array}{c}1.29 \\
(4.19)\end{array}$ & $\begin{array}{c}11.3 \\
(8.64)\end{array}$ \\
\hline 4. Furnishings & $\begin{array}{c}1.55 \\
(0.95)\end{array}$ & $\begin{array}{c}-4.3 \\
(1.96)\end{array}$ & $\begin{array}{c}0.19 \\
(1.06)\end{array}$ & $\begin{array}{c}1.5 \\
(1.86)\end{array}$ & $\begin{array}{l}-4.77 \\
(1.51)\end{array}$ & $\begin{array}{c}1.22 \\
(0.74)\end{array}$ & $\begin{array}{c}1.54 \\
(1.26)\end{array}$ & $\begin{array}{c}0.33 \\
(0.85)\end{array}$ & $\begin{array}{c}1.44 \\
(1.20)\end{array}$ & $\begin{array}{c}2.86 \\
(2.47)\end{array}$ \\
\hline 5. Health & $\begin{array}{c}0.04 \\
(1.50)\end{array}$ & $\begin{array}{l}-1.87 \\
(3.09)\end{array}$ & $\begin{array}{c}2.85 \\
(1.68)\end{array}$ & $\begin{array}{l}-1.72 \\
(2.94)\end{array}$ & $\begin{array}{c}-0.95 \\
(2.39)\end{array}$ & $\begin{array}{c}-8.23 \\
(1.17)\end{array}$ & $\begin{array}{c}-0.36 \\
(1.99)\end{array}$ & $\begin{array}{c}3.01 \\
(1.35)\end{array}$ & $\begin{array}{c}-0.36 \\
(1.89)\end{array}$ & $\begin{array}{c}7.62 \\
(3.90)\end{array}$ \\
\hline 6. Education & $\begin{array}{l}-0.95 \\
(1.89)\end{array}$ & $\begin{array}{c}-3.85 \\
(3.90)\end{array}$ & $\begin{array}{c}-1.39 \\
(2.12)\end{array}$ & $\begin{array}{c}3.74 \\
(3.71)\end{array}$ & $\begin{array}{c}3.15 \\
(3.01)\end{array}$ & $\begin{array}{c}1.05 \\
(1.48)\end{array}$ & $\begin{array}{l}-6.17 \\
(2.50)\end{array}$ & $\begin{array}{c}2.57 \\
(1.70)\end{array}$ & $\begin{array}{c}5.64 \\
(2.38)\end{array}$ & $\begin{array}{l}-4.74 \\
(4.91)\end{array}$ \\
\hline 7. Restaurants & $\begin{array}{l}-1.37 \\
(2.21)\end{array}$ & $\begin{array}{c}-4.02 \\
(4.55)\end{array}$ & $\begin{array}{c}2.77 \\
(2.48)\end{array}$ & $\begin{array}{c}2.5 \\
(4.33)\end{array}$ & $\begin{array}{c}-2.97 \\
(3.52)\end{array}$ & $\begin{array}{c}1.03 \\
(1.73)\end{array}$ & $\begin{array}{l}-4.83 \\
(2.92)\end{array}$ & $\begin{array}{c}-3.42 \\
(1.99)\end{array}$ & $\begin{array}{c}0.08 \\
(2.78)\end{array}$ & $\begin{array}{c}8.86 \\
(5.74)\end{array}$ \\
\hline 8. Recreation & $\begin{array}{c}0.96 \\
(1.13)\end{array}$ & $\begin{array}{c}0.33 \\
(2.32)\end{array}$ & $\begin{array}{c}0.21 \\
(1.26)\end{array}$ & $\begin{array}{c}-5.8 \\
(2.21)\end{array}$ & $\begin{array}{c}1.68 \\
(1.79)\end{array}$ & $\begin{array}{c}-0.87 \\
(0.88)\end{array}$ & $\begin{array}{c}1.76 \\
(1.49)\end{array}$ & $\begin{array}{c}1.89 \\
(1.01)\end{array}$ & $\begin{array}{c}-8.79 \\
(1.42)\end{array}$ & $\begin{array}{c}9.6 \\
(2.93)\end{array}$ \\
\hline 9. Miscellaneous & $\begin{array}{c}4.22 \\
(3.28)\end{array}$ & $\begin{array}{l}17.41 \\
(6.75)\end{array}$ & $\begin{array}{c}3.16 \\
(3.67)\end{array}$ & $\begin{array}{l}-12.44 \\
(6.42)\end{array}$ & $\begin{array}{c}-3.92 \\
(5.22)\end{array}$ & $\begin{array}{c}2.18 \\
(2.57)\end{array}$ & $\begin{array}{c}0.76 \\
(4.34)\end{array}$ & $\begin{array}{l}-2.29 \\
(2.95)\end{array}$ & $\begin{array}{c}-4.93 \\
(4.12)\end{array}$ & $\begin{array}{c}0.07 \\
(8.51)\end{array}$ \\
\hline \multicolumn{11}{|c|}{ B. Symmetry-constrained } \\
\hline 1. Food & $\begin{array}{c}-4 \\
(4.75)\end{array}$ & $\begin{array}{c}0.36 \\
(9.08)\end{array}$ & $\begin{array}{c}3.82 \\
(2.28)\end{array}$ & $\begin{array}{c}1.16 \\
(4.86)\end{array}$ & $\begin{array}{c}-3.59 \\
(1.89)\end{array}$ & $\begin{array}{l}-1.16 \\
(2.24)\end{array}$ & $\begin{array}{c}-0.12 \\
(3.24)\end{array}$ & $\begin{array}{l}-5.69 \\
(2.99)\end{array}$ & $\begin{array}{c}0 \\
(2.05)\end{array}$ & $\begin{array}{c}5.22 \\
(6.18)\end{array}$ \\
\hline 2. Clothing & $\begin{array}{l}-1.03 \\
(1.38)\end{array}$ & & $\begin{array}{c}-4.12 \\
(1.35)\end{array}$ & $\begin{array}{c}1.35 \\
(1.96)\end{array}$ & $\begin{array}{c}-0.36 \\
(0.94)\end{array}$ & $\begin{array}{l}-2.89 \\
(0.84)\end{array}$ & $\begin{array}{c}-0.35 \\
(1.26)\end{array}$ & $\begin{array}{c}0.37 \\
(1.00)\end{array}$ & $\begin{array}{c}-1 \\
(0.92)\end{array}$ & $\begin{array}{c}3.17 \\
(2.34)\end{array}$ \\
\hline 3. Housing & $\begin{array}{c}1.63 \\
(3.57)\end{array}$ & & & $\begin{array}{c}-11.2 \\
(5.03)\end{array}$ & $\begin{array}{c}1.98 \\
(1.68)\end{array}$ & $\begin{array}{c}2.94 \\
(1.71)\end{array}$ & $\begin{array}{c}0.68 \\
(2.57)\end{array}$ & $\begin{array}{c}5.12 \\
(2.13)\end{array}$ & $\begin{array}{l}-2.32 \\
(1.72)\end{array}$ & $\begin{array}{c}0.32 \\
(4.49)\end{array}$ \\
\hline 4. Furnishings & $\begin{array}{c}1.61 \\
(0.97)\end{array}$ & & & & $\begin{array}{c}-4.11 \\
(1.49)\end{array}$ & $\begin{array}{c}1.42 \\
(0.71)\end{array}$ & $\begin{array}{c}1.67 \\
(1.15)\end{array}$ & $\begin{array}{c}-0.03 \\
(0.82)\end{array}$ & $\begin{array}{c}1.86 \\
(0.96)\end{array}$ & $\begin{array}{c}1.16 \\
(2.20)\end{array}$ \\
\hline 5. Health & $\begin{array}{c}0.51 \\
(1.62)\end{array}$ & & & & & $\begin{array}{c}-8.18 \\
(1.13)\end{array}$ & $\begin{array}{c}1.22 \\
(1.16)\end{array}$ & $\begin{array}{c}2.03 \\
(1.05)\end{array}$ & $\begin{array}{c}0.04 \\
(0.77)\end{array}$ & $\begin{array}{c}4.58 \\
(2.22)\end{array}$ \\
\hline 6. Education & $\begin{array}{c}-0.71 \\
(1.98)\end{array}$ & & & & & & $\begin{array}{l}-6.47 \\
(2.45)\end{array}$ & $\begin{array}{c}1.41 \\
(1.45)\end{array}$ & $\begin{array}{c}3.18 \\
(1.20)\end{array}$ & $\begin{array}{l}-1.22 \\
(3.16)\end{array}$ \\
\hline 7. Restaurants & $\begin{array}{l}-2.12 \\
(2.35)\end{array}$ & & & & & & & $\begin{array}{l}-3.09 \\
(1.90)\end{array}$ & $\begin{array}{c}1.78 \\
(0.91)\end{array}$ & $\begin{array}{l}-1.91 \\
(2.57)\end{array}$ \\
\hline 8. Recreation & $\begin{array}{c}0.74 \\
(1.18)\end{array}$ & & & & & & & & $\begin{array}{l}-7.47 \\
(1.29)\end{array}$ & $\begin{array}{c}3.93 \\
(2.33)\end{array}$ \\
\hline 9. Miscellaneous & $\begin{array}{c}3.38 \\
(3.56)\end{array}$ & & & & & & & & & $\begin{array}{r}-15.26 \\
(7.98)\end{array}$ \\
\hline \multicolumn{11}{|c|}{ C. No price effects } \\
\hline 1. Food & $\begin{array}{l}-3.33 \\
(4.56)\end{array}$ & & & & & & & & & \\
\hline 2. Clothing & $\begin{array}{l}-1.39 \\
(1.42)\end{array}$ & & & & & & & & & \\
\hline 3. Housing & $\begin{array}{c}0.67 \\
(3.69)\end{array}$ & & & & & & & & & \\
\hline 4. Furnishings & $\begin{array}{c}1.42 \\
(1.09)\end{array}$ & & & & & & & & & \\
\hline 5. Health & $\begin{array}{c}1.84 \\
(2.23)\end{array}$ & & & & & & & & & \\
\hline 6. Education & $\begin{array}{c}-1.9 \\
(2.13)\end{array}$ & & & & & & & & & \\
\hline 7. Restaurants & $\begin{array}{l}-1.79 \\
(2.23)\end{array}$ & & & & & & & & & \\
\hline 8. Recreation & $\begin{array}{c}1.25 \\
(1.51)\end{array}$ & & & & & & & & & \\
\hline 9. Miscellaneous & $\begin{array}{c}3.23 \\
(3.44)\end{array}$ & & & & & & & & & \\
\hline
\end{tabular}


A-31

Table A7.6. Demand Equations, Fourth Income Quartile

\begin{tabular}{|c|c|c|c|c|c|c|c|c|c|c|}
\hline \multirow{2}{*}{$\begin{array}{c}\text { Commodity } i \\
\text { (1) }\end{array}$} & \multirow{2}{*}{$\begin{array}{c}\text { Income } \\
\text { coefficient } \\
\beta_{i} \\
(2) \\
\end{array}$} & \multicolumn{9}{|c|}{ Price coefficients } \\
\hline & & $\begin{array}{r}\pi_{1 j} \\
(3) \\
\end{array}$ & $\begin{array}{r}\pi_{2 j} \\
(4) \\
\end{array}$ & $\begin{array}{l}\pi_{3 j} \\
(5) \\
\end{array}$ & $\begin{array}{r}\pi_{4 j} \\
(6) \\
\end{array}$ & $\begin{array}{r}\pi_{5 j} \\
(7)\end{array}$ & $\begin{array}{r}\pi_{6 j} \\
(8)\end{array}$ & $\begin{array}{r}\pi_{7 j} \\
(9) \\
\end{array}$ & $\begin{array}{c}\pi_{8 j} \\
(10)\end{array}$ & $\begin{array}{l}\pi_{9 j} \\
(11)\end{array}$ \\
\hline \multicolumn{11}{|c|}{ A. Homogeneity-constrained } \\
\hline 1. Food & $\begin{array}{l}-4.97 \\
(2.46)\end{array}$ & $\begin{array}{c}-11.99 \\
(7.29)\end{array}$ & $\begin{array}{c}5.19 \\
(5.31)\end{array}$ & $\begin{array}{c}0.73 \\
(7.21)\end{array}$ & $\begin{array}{c}3.73 \\
(7.41)\end{array}$ & $\begin{array}{c}8.48 \\
(3.81)\end{array}$ & $\begin{array}{c}-7.61 \\
(5.66)\end{array}$ & $\begin{array}{c}0.59 \\
(3.92)\end{array}$ & $\begin{array}{c}-6.84 \\
(5.89)\end{array}$ & $\begin{array}{c}7.73 \\
(9.47)\end{array}$ \\
\hline 2. Clothing & $\begin{array}{c}0.87 \\
(0.74)\end{array}$ & $\begin{array}{c}5.03 \\
(2.19)\end{array}$ & $\begin{array}{c}-5.23 \\
(1.60)\end{array}$ & $\begin{array}{l}-1.16 \\
(2.17)\end{array}$ & $\begin{array}{c}-3.84 \\
(2.23)\end{array}$ & $\begin{array}{c}-2.42 \\
(1.15)\end{array}$ & $\begin{array}{c}2.73 \\
(1.70)\end{array}$ & $\begin{array}{c}-2.01 \\
(1.18)\end{array}$ & $\begin{array}{c}2.84 \\
(1.77)\end{array}$ & $\begin{array}{c}4.06 \\
(2.85)\end{array}$ \\
\hline 3. Housing & $\begin{array}{l}-0.91 \\
(1.92)\end{array}$ & $\begin{array}{c}3.84 \\
(5.68)\end{array}$ & $\begin{array}{c}2.83 \\
(4.14)\end{array}$ & $\begin{array}{c}-2.59 \\
(5.62)\end{array}$ & $\begin{array}{c}-1.22 \\
(5.78)\end{array}$ & $\begin{array}{c}1.17 \\
(2.97)\end{array}$ & $\begin{array}{c}0.35 \\
(4.41)\end{array}$ & $\begin{array}{c}5.52 \\
(3.05)\end{array}$ & $\begin{array}{l}-6.55 \\
(4.59)\end{array}$ & $\begin{array}{c}-3.35 \\
(7.38)\end{array}$ \\
\hline 4. Furnishings & $\begin{array}{c}0.35 \\
(0.55)\end{array}$ & $\begin{array}{l}-1.25 \\
(1.62)\end{array}$ & $\begin{array}{c}0.94 \\
(1.18)\end{array}$ & $\begin{array}{c}1.25 \\
(1.60)\end{array}$ & $\begin{array}{c}-5.18 \\
(1.65)\end{array}$ & $\begin{array}{c}1.8 \\
(0.85)\end{array}$ & $\begin{array}{c}1.19 \\
(1.26)\end{array}$ & $\begin{array}{c}-0.03 \\
(0.87)\end{array}$ & $\begin{array}{c}-0.08 \\
(1.31)\end{array}$ & $\begin{array}{c}1.36 \\
(2.11)\end{array}$ \\
\hline 5. Health & $\begin{array}{c}0.4 \\
(0.86)\end{array}$ & $\begin{array}{c}0.1 \\
(2.56)\end{array}$ & $\begin{array}{c}-1.96 \\
(1.87)\end{array}$ & $\begin{array}{c}3.09 \\
(2.53)\end{array}$ & $\begin{array}{c}2.72 \\
(2.60)\end{array}$ & $\begin{array}{r}-5.04 \\
(1.34)\end{array}$ & $\begin{array}{c}-0.23 \\
(1.99)\end{array}$ & $\begin{array}{l}-2.62 \\
(1.38)\end{array}$ & $\begin{array}{c}3.83 \\
(2.07)\end{array}$ & $\begin{array}{c}0.1 \\
(3.33)\end{array}$ \\
\hline 6. Education & $\begin{array}{l}-0.39 \\
(1.09)\end{array}$ & $\begin{array}{c}2.8 \\
(3.23)\end{array}$ & $\begin{array}{c}1.34 \\
(2.35)\end{array}$ & $\begin{array}{c}1.55 \\
(3.19)\end{array}$ & $\begin{array}{c}-0.64 \\
(3.28)\end{array}$ & $\begin{array}{c}0.17 \\
(1.69)\end{array}$ & $\begin{array}{l}-3.67 \\
(2.51)\end{array}$ & $\begin{array}{c}-0.65 \\
(1.74)\end{array}$ & $\begin{array}{l}-0.21 \\
(2.61)\end{array}$ & $\begin{array}{c}-0.67 \\
(4.20)\end{array}$ \\
\hline 7. Restaurants & $\begin{array}{l}-0.36 \\
(1.27)\end{array}$ & $\begin{array}{c}-0.37 \\
(3.77)\end{array}$ & $\begin{array}{c}1.09 \\
(2.75)\end{array}$ & $\begin{array}{c}2.55 \\
(3.73)\end{array}$ & $\begin{array}{c}-2.15 \\
(3.84)\end{array}$ & $\begin{array}{c}0.94 \\
(1.97)\end{array}$ & $\begin{array}{c}2.92 \\
(2.93)\end{array}$ & $\begin{array}{c}0.28 \\
(2.03)\end{array}$ & $\begin{array}{l}-2.45 \\
(3.05)\end{array}$ & $\begin{array}{c}-2.82 \\
(4.90)\end{array}$ \\
\hline 8. Recreation & $\begin{array}{l}-0.03 \\
(0.65)\end{array}$ & $\begin{array}{c}-1.6 \\
(1.92)\end{array}$ & $\begin{array}{c}1.54 \\
(1.40)\end{array}$ & $\begin{array}{c}-2.46 \\
(1.90)\end{array}$ & $\begin{array}{c}1.59 \\
(1.96)\end{array}$ & $\begin{array}{c}-0.86 \\
(1.01)\end{array}$ & $\begin{array}{c}0.42 \\
(1.49)\end{array}$ & $\begin{array}{c}-0.41 \\
(1.03)\end{array}$ & $\begin{array}{c}0.15 \\
(1.55)\end{array}$ & $\begin{array}{c}1.64 \\
(2.50)\end{array}$ \\
\hline 9. Miscellaneous & $\begin{array}{c}5.05 \\
(1.89)\end{array}$ & $\begin{array}{c}3.44 \\
(5.59)\end{array}$ & $\begin{array}{c}-5.73 \\
(4.08)\end{array}$ & $\begin{array}{l}-2.97 \\
(5.53)\end{array}$ & $\begin{array}{c}5 \\
(5.69)\end{array}$ & $\begin{array}{l}-4.24 \\
(2.93)\end{array}$ & $\begin{array}{c}3.9 \\
(4.35)\end{array}$ & $\begin{array}{c}-0.67 \\
(3.01)\end{array}$ & $\begin{array}{c}9.32 \\
(4.52)\end{array}$ & $\begin{array}{r}-8.05 \\
(7.27)\end{array}$ \\
\hline \multicolumn{11}{|c|}{ B. Symmetry-constrained } \\
\hline 1. Food & $\begin{array}{l}-4.95 \\
(2.61)\end{array}$ & $\begin{array}{r}-16.17 \\
(7.58)\end{array}$ & $\begin{array}{c}4.53 \\
(2.05)\end{array}$ & $\begin{array}{c}0.01 \\
(4.25)\end{array}$ & $\begin{array}{c}-1.46 \\
(1.57)\end{array}$ & $\begin{array}{c}2.96 \\
(2.04)\end{array}$ & $\begin{array}{c}1.07 \\
(2.86)\end{array}$ & $\begin{array}{c}1.02 \\
(2.68)\end{array}$ & $\begin{array}{c}-0.71 \\
(1.90)\end{array}$ & $\begin{array}{c}8.75 \\
(5.11)\end{array}$ \\
\hline 2. Clothing & $\begin{array}{c}0.7 \\
(0.78)\end{array}$ & & $\begin{array}{c}-5.11 \\
(1.55)\end{array}$ & $\begin{array}{c}-0.48 \\
(1.79)\end{array}$ & $\begin{array}{c}-0.04 \\
(1.05)\end{array}$ & $\begin{array}{c}-1.54 \\
(0.91)\end{array}$ & $\begin{array}{c}1.95 \\
(1.35)\end{array}$ & $\begin{array}{c}-1.88 \\
(1.03)\end{array}$ & $\begin{array}{c}2.29 \\
(1.07)\end{array}$ & $\begin{array}{c}0.27 \\
(2.40)\end{array}$ \\
\hline 3. Housing & $\begin{array}{c}-0.08 \\
(1.99)\end{array}$ & & & $\begin{array}{c}-0.01 \\
(4.52)\end{array}$ & $\begin{array}{c}1.66 \\
(1.52)\end{array}$ & $\begin{array}{c}2.2 \\
(1.68)\end{array}$ & $\begin{array}{c}0.62 \\
(2.37)\end{array}$ & $\begin{array}{c}3.21 \\
(2.05)\end{array}$ & $\begin{array}{l}-2.85 \\
(1.62)\end{array}$ & $\begin{array}{c}-4.36 \\
(4.16)\end{array}$ \\
\hline 4. Furnishings & $\begin{array}{c}0.46 \\
(0.55)\end{array}$ & & & & $\begin{array}{l}-4.47 \\
(1.63)\end{array}$ & $\begin{array}{c}1.79 \\
(0.78)\end{array}$ & $\begin{array}{c}0.95 \\
(1.18)\end{array}$ & $\begin{array}{c}-0.34 \\
(0.84)\end{array}$ & $\begin{array}{c}0.39 \\
(1.08)\end{array}$ & $\begin{array}{c}1.53 \\
(2.03)\end{array}$ \\
\hline 5. Health & $\begin{array}{c}0.05 \\
(0.91)\end{array}$ & & & & & $\begin{array}{c}-4.18 \\
(1.17)\end{array}$ & $\begin{array}{c}0.16 \\
(1.22)\end{array}$ & $\begin{array}{c}-1.24 \\
(1.03)\end{array}$ & $\begin{array}{l}-0.04 \\
(0.90)\end{array}$ & $\begin{array}{c}-0.1 \\
(2.10)\end{array}$ \\
\hline 6. Education & $\begin{array}{l}-0.56 \\
(1.11)\end{array}$ & & & & & & $\begin{array}{l}-3.86 \\
(2.45)\end{array}$ & $\begin{array}{c}0.12 \\
(1.41)\end{array}$ & $\begin{array}{l}-0.47 \\
(1.26)\end{array}$ & $\begin{array}{c}-0.53 \\
(2.95)\end{array}$ \\
\hline 7. Restaurants & $\begin{array}{c}-0.24 \\
(1.30)\end{array}$ & & & & & & & $\begin{array}{c}-0.69 \\
(1.81)\end{array}$ & $\begin{array}{l}-0.23 \\
(0.93)\end{array}$ & $\begin{array}{c}0.03 \\
(2.51)\end{array}$ \\
\hline 8. Recreation & $\begin{array}{l}-0.04 \\
(0.68)\end{array}$ & & & & & & & & $\begin{array}{l}-1.18 \\
(1.50)\end{array}$ & $\begin{array}{c}2.8 \\
(2.10)\end{array}$ \\
\hline 9. Miscellaneous & $\begin{array}{c}4.66 \\
(1.99)\end{array}$ & & & & & & & & & $\begin{array}{c}-8.4 \\
(7.07)\end{array}$ \\
\hline \multicolumn{11}{|c|}{ C. No price effects } \\
\hline 1. Food & $\begin{array}{l}-4.93 \\
(2.47)\end{array}$ & & & & & & & & & \\
\hline 2. Clothing & $\begin{array}{l}-0.03 \\
(0.77)\end{array}$ & & & & & & & & & \\
\hline 3. Housing & $\begin{array}{c}0.13 \\
(2.00)\end{array}$ & & & & & & & & & \\
\hline 4. Furnishings & $\begin{array}{l}-0.05 \\
(0.59)\end{array}$ & & & & & & & & & \\
\hline 5. Health & $\begin{array}{c}0.9 \\
(1.20)\end{array}$ & & & & & & & & & \\
\hline 6. Education & $\begin{array}{l}-0.22 \\
(1.15)\end{array}$ & & & & & & & & & \\
\hline 7. Restaurants & $\begin{array}{c}0.04 \\
(1.21)\end{array}$ & & & & & & & & & \\
\hline 8. Recreation & $\begin{array}{c}0.12 \\
(0.81)\end{array}$ & & & & & & & & & \\
\hline 9. Miscellaneous & $\begin{array}{c}4.05 \\
(1.86)\end{array}$ & & & & & & & & & \\
\hline
\end{tabular}


A-32

Table A7.7. Demand Equations, Rich Countries

\begin{tabular}{|c|c|c|c|c|c|c|c|c|c|c|}
\hline \multirow{2}{*}{$\begin{array}{c}\text { Commodity } i \\
(1) \\
\end{array}$} & \multirow{2}{*}{$\begin{array}{c}\text { Income } \\
\text { coefficient } \\
\beta_{i} \\
(2) \\
\end{array}$} & \multicolumn{9}{|c|}{ Price coefficients } \\
\hline & & $\begin{array}{l}\pi_{1 j} \\
(3) \\
\end{array}$ & $\begin{array}{r}\pi_{2 j} \\
(4) \\
\end{array}$ & $\begin{array}{r}\pi_{3 j} \\
(5) \\
\end{array}$ & $\begin{array}{r}\pi_{4 j} \\
(6) \\
\end{array}$ & $\begin{array}{l}\pi_{5 j} \\
(7) \\
\end{array}$ & $\begin{array}{r}\pi_{6 j} \\
(8) \\
\end{array}$ & $\begin{array}{l}\pi_{7 j} \\
(9) \\
\end{array}$ & $\begin{array}{l}\pi_{8 j} \\
(10)\end{array}$ & $\begin{array}{l}\pi_{9 j} \\
(11)\end{array}$ \\
\hline \multicolumn{11}{|c|}{ A. Homogeneity-constrained } \\
\hline 1. Food & $\begin{array}{l}-1.84 \\
(2.94)\end{array}$ & $\begin{array}{r}-14.24 \\
(5.64)\end{array}$ & $\begin{array}{c}4.16 \\
(4.89)\end{array}$ & $\begin{array}{c}9.37 \\
(7.19)\end{array}$ & $\begin{array}{c}3.87 \\
(4.98)\end{array}$ & $\begin{array}{l}-0.92 \\
(2.85)\end{array}$ & $\begin{array}{c}3.92 \\
(4.99)\end{array}$ & $\begin{array}{l}-1.63 \\
(3.43)\end{array}$ & $\begin{array}{l}-3.79 \\
(4.06)\end{array}$ & $\begin{array}{c}-0.73 \\
(8.30)\end{array}$ \\
\hline 2. Clothing & $\begin{array}{l}-0.03 \\
(0.83)\end{array}$ & $\begin{array}{c}-0.07 \\
(1.60)\end{array}$ & $\begin{array}{c}-3.19 \\
(1.39)\end{array}$ & $\begin{array}{c}2.19 \\
(2.04)\end{array}$ & $\begin{array}{l}-1.49 \\
(1.41)\end{array}$ & $\begin{array}{c}0.29 \\
(0.81)\end{array}$ & $\begin{array}{c}1.82 \\
(1.42)\end{array}$ & $\begin{array}{l}-1.32 \\
(0.97)\end{array}$ & $\begin{array}{l}-0.12 \\
(1.15)\end{array}$ & $\begin{array}{c}1.87 \\
(2.35)\end{array}$ \\
\hline 3. Housing & $\begin{array}{l}-0.46 \\
(2.30)\end{array}$ & $\begin{array}{c}4.88 \\
(4.41)\end{array}$ & $\begin{array}{l}-4.62 \\
(3.83)\end{array}$ & $\begin{array}{r}-11.79 \\
(5.62)\end{array}$ & $\begin{array}{l}-4.88 \\
(3.90)\end{array}$ & $\begin{array}{c}6.74 \\
(2.23)\end{array}$ & $\begin{array}{c}7.3 \\
(3.91)\end{array}$ & $\begin{array}{c}3.18 \\
(2.68)\end{array}$ & $\begin{array}{c}-0.93 \\
(3.18)\end{array}$ & $\begin{array}{c}0.12 \\
(6.49)\end{array}$ \\
\hline 4. Furnishings & $\begin{array}{c}0.35 \\
(0.61)\end{array}$ & $\begin{array}{c}0.73 \\
(1.17)\end{array}$ & $\begin{array}{l}-0.61 \\
(1.02)\end{array}$ & $\begin{array}{c}1.91 \\
(1.50)\end{array}$ & $\begin{array}{c}-5.75 \\
(1.04)\end{array}$ & $\begin{array}{c}1.39 \\
(0.59)\end{array}$ & $\begin{array}{c}1.75 \\
(1.04)\end{array}$ & $\begin{array}{l}-0.67 \\
(0.71)\end{array}$ & $\begin{array}{c}-0.5 \\
(0.85)\end{array}$ & $\begin{array}{c}1.74 \\
(1.73)\end{array}$ \\
\hline 5. Health & $\begin{array}{l}-2.01 \\
(1.04)\end{array}$ & $\begin{array}{l}-1.01 \\
(1.99)\end{array}$ & $\begin{array}{c}1.59 \\
(1.72)\end{array}$ & $\begin{array}{l}-3.27 \\
(2.53)\end{array}$ & $\begin{array}{c}1.75 \\
(1.75)\end{array}$ & $\begin{array}{r}-10.03 \\
(1.00)\end{array}$ & $\begin{array}{c}3.99 \\
(1.76)\end{array}$ & $\begin{array}{c}0.97 \\
(1.21)\end{array}$ & $\begin{array}{c}3.08 \\
(1.43)\end{array}$ & $\begin{array}{c}2.92 \\
(2.92)\end{array}$ \\
\hline 6. Education & $\begin{array}{c}-0.48 \\
(1.22)\end{array}$ & $\begin{array}{c}1.48 \\
(2.35)\end{array}$ & $\begin{array}{c}3.45 \\
(2.04)\end{array}$ & $\begin{array}{l}-6.81 \\
(2.99)\end{array}$ & $\begin{array}{l}-1.48 \\
(2.07)\end{array}$ & $\begin{array}{c}1.09 \\
(1.19)\end{array}$ & $\begin{array}{c}\mathbf{- 9 . 9 8} \\
(\mathbf{2 . 0 8 )}\end{array}$ & $\begin{array}{c}-0.96 \\
(1.43)\end{array}$ & $\begin{array}{c}1.78 \\
(1.69)\end{array}$ & $\begin{array}{l}11.44 \\
(3.45)\end{array}$ \\
\hline 7. Restaurants & $\begin{array}{c}1.73 \\
(1.44)\end{array}$ & $\begin{array}{c}-0.91 \\
(2.76)\end{array}$ & $\begin{array}{c}0.75 \\
(2.39)\end{array}$ & $\begin{array}{c}1.95 \\
(3.52)\end{array}$ & $\begin{array}{c}2.51 \\
(2.44)\end{array}$ & $\begin{array}{c}0.19 \\
(1.39)\end{array}$ & $\begin{array}{l}-4.92 \\
(2.44)\end{array}$ & $\begin{array}{l}-5.31 \\
(1.68)\end{array}$ & $\begin{array}{c}1.38 \\
(1.99)\end{array}$ & $\begin{array}{c}4.36 \\
(4.06)\end{array}$ \\
\hline 8. Recreation & $\begin{array}{c}2.38 \\
(0.76)\end{array}$ & $\begin{array}{c}-0.03 \\
(1.46)\end{array}$ & $\begin{array}{c}2.52 \\
(1.26)\end{array}$ & $\begin{array}{c}1.88 \\
(1.86)\end{array}$ & $\begin{array}{c}0.5 \\
(1.29)\end{array}$ & $\begin{array}{l}-0.08 \\
(0.74)\end{array}$ & $\begin{array}{c}-2.76 \\
(1.29)\end{array}$ & $\begin{array}{c}1.91 \\
(0.89)\end{array}$ & $\begin{array}{l}-7.95 \\
(1.05)\end{array}$ & $\begin{array}{c}4.01 \\
(2.14)\end{array}$ \\
\hline 9. Miscellaneous & $\begin{array}{c}0.37 \\
(2.09)\end{array}$ & $\begin{array}{c}9.17 \\
(4.01)\end{array}$ & $\begin{array}{l}-4.06 \\
(3.48)\end{array}$ & $\begin{array}{c}4.55 \\
(5.11)\end{array}$ & $\begin{array}{c}4.96 \\
(3.54)\end{array}$ & $\begin{array}{c}1.33 \\
(2.02)\end{array}$ & $\begin{array}{l}-1.11 \\
(3.55)\end{array}$ & $\begin{array}{c}3.82 \\
(2.44)\end{array}$ & $\begin{array}{c}7.05 \\
(2.89)\end{array}$ & $\begin{array}{r}-25.71 \\
(5.90)\end{array}$ \\
\hline \multicolumn{11}{|c|}{ B. Symmetry-constrained } \\
\hline 1. Food & $\begin{array}{l}-3.58 \\
(2.56)\end{array}$ & $\begin{array}{r}-15.39 \\
(5.23)\end{array}$ & $\begin{array}{c}0.95 \\
(1.46)\end{array}$ & $\begin{array}{l}10.27 \\
(3.51)\end{array}$ & $\begin{array}{c}1.44 \\
(1.11)\end{array}$ & $\begin{array}{l}-1.12 \\
(1.61)\end{array}$ & $\begin{array}{c}1.26 \\
(2.09)\end{array}$ & $\begin{array}{l}-2.56 \\
(2.02)\end{array}$ & $\begin{array}{l}-1.81 \\
(1.31)\end{array}$ & $\begin{array}{c}6.95 \\
(3.53)\end{array}$ \\
\hline 2. Clothing & $\begin{array}{c}0.12 \\
(0.80)\end{array}$ & & $\begin{array}{l}-2.68 \\
(1.19)\end{array}$ & $\begin{array}{c}2.19 \\
(1.62)\end{array}$ & $\begin{array}{l}-0.25 \\
(0.76)\end{array}$ & $\begin{array}{c}0.02 \\
(0.69)\end{array}$ & $\begin{array}{c}1.05 \\
(1.10)\end{array}$ & $\begin{array}{l}-0.76 \\
(0.84)\end{array}$ & $\begin{array}{c}0.78 \\
(0.75)\end{array}$ & $\begin{array}{l}-1.32 \\
(1.75)\end{array}$ \\
\hline 3. Housing & $\begin{array}{l}-0.29 \\
(2.14)\end{array}$ & & & $\begin{array}{l}-19.5 \\
(4.65)\end{array}$ & $\begin{array}{c}1.3 \\
(1.32)\end{array}$ & $\begin{array}{c}0.91 \\
(1.52)\end{array}$ & $\begin{array}{l}-3.25 \\
(2.17)\end{array}$ & $\begin{array}{c}4.3 \\
(1.92)\end{array}$ & $\begin{array}{c}2.86 \\
(1.41)\end{array}$ & $\begin{array}{c}0.92 \\
(3.58)\end{array}$ \\
\hline 4. Furnishings & $\begin{array}{c}0.39 \\
(0.59)\end{array}$ & & & & $\begin{array}{l}-5.16 \\
(0.96)\end{array}$ & $\begin{array}{c}1.15 \\
(0.54)\end{array}$ & $\begin{array}{c}0.66 \\
(0.88)\end{array}$ & $\begin{array}{l}-0.32 \\
(0.66)\end{array}$ & $\begin{array}{l}-0.27 \\
(0.66)\end{array}$ & $\begin{array}{c}1.44 \\
(1.44)\end{array}$ \\
\hline 5. Health & $\begin{array}{l}-0.91 \\
(0.94)\end{array}$ & & & & & $\begin{array}{c}-9.18 \\
(0.99)\end{array}$ & $\begin{array}{c}2.87 \\
(0.97)\end{array}$ & $\begin{array}{c}1.1 \\
(0.88)\end{array}$ & $\begin{array}{c}1.18 \\
(0.62)\end{array}$ & $\begin{array}{c}3.07 \\
(1.58)\end{array}$ \\
\hline 6. Education & $\begin{array}{c}0.85 \\
(1.18)\end{array}$ & & & & & & $\begin{array}{l}-8.73 \\
(2.00)\end{array}$ & $\begin{array}{c}-0.85 \\
(1.20)\end{array}$ & $\begin{array}{c}0.28 \\
(0.94)\end{array}$ & $\begin{array}{c}6.7 \\
(2.32)\end{array}$ \\
\hline 7. Restaurants & $\begin{array}{c}1.18 \\
(1.34)\end{array}$ & & & & & & & $\begin{array}{c}-5.9 \\
(1.55)\end{array}$ & $\begin{array}{c}1.34 \\
(0.76)\end{array}$ & $\begin{array}{c}3.64 \\
(2.03)\end{array}$ \\
\hline 8. Recreation & $\begin{array}{c}2.23 \\
(0.75)\end{array}$ & & & & & & & & $\begin{array}{c}\mathbf{- 8 . 9 8} \\
(0.94)\end{array}$ & $\begin{array}{c}4.62 \\
(1.64)\end{array}$ \\
\hline 9. Miscellaneous & $\begin{array}{c}0.01 \\
(1.99)\end{array}$ & & & & & & & & & $\begin{array}{c}-26.02 \\
(5.26)\end{array}$ \\
\hline \multicolumn{11}{|c|}{ C. No price effects } \\
\hline 1. Food & $\begin{array}{l}-3.31 \\
(1.99)\end{array}$ & & & & & & & & & \\
\hline 2. Clothing & $\begin{array}{c}0.09 \\
(0.60)\end{array}$ & & & & & & & & & \\
\hline 3. Housing & $\begin{array}{c}2.55 \\
(1.59)\end{array}$ & & & & & & & & & \\
\hline 4. Furnishings & $\begin{array}{c}0.36 \\
(0.47)\end{array}$ & & & & & & & & & \\
\hline 5. Health & $\begin{array}{c}1.94 \\
(0.96)\end{array}$ & & & & & & & & & \\
\hline 6. Education & $\begin{array}{l}-0.28 \\
(0.90)\end{array}$ & & & & & & & & & \\
\hline 7. Restaurants & $\begin{array}{l}-0.92 \\
(0.94)\end{array}$ & & & & & & & & & \\
\hline 8. Recreation & $\begin{array}{c}-0.5 \\
(0.63)\end{array}$ & & & & & & & & & \\
\hline 9. Miscellaneous & $\begin{array}{c}0.08 \\
(1.47) \\
\end{array}$ & & & & & & & & & \\
\hline
\end{tabular}

Note: This table presents three sets of estimates of model (A7.1) for countries with incomes greater than the median. Intercepts are included in each equation, but these are omitted from this table. All entries are multiplied by 100 . Own-price coefficients and their standard errors are emboldened. Standard errors, obtained from 1,000 bootstrap replications, in parentheses. 
A-33

Table A7.8. Demand Equations, Poor Countries

\begin{tabular}{|c|c|c|c|c|c|c|c|c|c|c|}
\hline \multirow{2}{*}{$\begin{array}{c}\text { Commodity } i \\
\text { (1) }\end{array}$} & \multirow{2}{*}{$\begin{array}{c}\text { Income } \\
\text { coefficient } \\
\beta_{i} \\
(2)\end{array}$} & \multicolumn{9}{|c|}{ Price coefficients } \\
\hline & & $\begin{array}{l}\pi_{1 j} \\
(3)\end{array}$ & $\begin{array}{l}\pi_{2 j} \\
(4)\end{array}$ & $\begin{array}{c}\pi_{3 j} \\
(5)\end{array}$ & $\begin{array}{c}\pi_{4 j} \\
(6)\end{array}$ & $\begin{array}{l}\pi_{5 j} \\
(7)\end{array}$ & $\begin{array}{l}\pi_{6 j} \\
(8)\end{array}$ & $\begin{array}{l}\pi_{7 j} \\
(9)\end{array}$ & $\begin{array}{c}\pi_{8 j} \\
(10)\end{array}$ & $\begin{array}{l}\pi_{9 j} \\
(11)\end{array}$ \\
\hline \multicolumn{11}{|c|}{ A. Homogeneity-constrained } \\
\hline 1. Food & $\begin{array}{l}-1.64 \\
(1.42)\end{array}$ & $\begin{array}{r}-13.85 \\
(5.57)\end{array}$ & $\begin{array}{c}6.07 \\
(3.67)\end{array}$ & $\begin{array}{c}4.91 \\
(5.66)\end{array}$ & $\begin{array}{c}4.49 \\
(5.12)\end{array}$ & $\begin{array}{c}6.08 \\
(2.59)\end{array}$ & $\begin{array}{c}2.38 \\
(4.09)\end{array}$ & $\begin{array}{l}-1.01 \\
(2.81)\end{array}$ & $\begin{array}{l}-2.37 \\
(3.99)\end{array}$ & $\begin{array}{c}-6.7 \\
(7.06)\end{array}$ \\
\hline 2. Clothing & $\begin{array}{c}0.00 \\
(0.40)\end{array}$ & $\begin{array}{c}4.77 \\
(1.58)\end{array}$ & $\begin{array}{l}-4.57 \\
(1.04)\end{array}$ & $\begin{array}{c}0.89 \\
(1.61)\end{array}$ & $\begin{array}{l}-3.62 \\
(1.45)\end{array}$ & $\begin{array}{l}-3.29 \\
(0.74)\end{array}$ & $\begin{array}{c}1.1 \\
(1.16)\end{array}$ & $\begin{array}{l}-0.31 \\
(0.80)\end{array}$ & $\begin{array}{c}1.37 \\
(1.13)\end{array}$ & $\begin{array}{c}3.65 \\
(2.00)\end{array}$ \\
\hline 3. Housing & $\begin{array}{c}0.67 \\
(1.11)\end{array}$ & $\begin{array}{l}-0.38 \\
(4.36)\end{array}$ & $\begin{array}{c}-3.9 \\
(2.88)\end{array}$ & $\begin{array}{l}-3.22 \\
(4.43)\end{array}$ & $\begin{array}{l}-0.33 \\
(4.01)\end{array}$ & $\begin{array}{l}-0.03 \\
(2.03)\end{array}$ & $\begin{array}{c}-0.9 \\
(3.20)\end{array}$ & $\begin{array}{c}3.85 \\
(2.20)\end{array}$ & $\begin{array}{c}-0.42 \\
(3.12)\end{array}$ & $\begin{array}{c}5.33 \\
(5.53)\end{array}$ \\
\hline 4. Furnishings & $\begin{array}{l}-0.22 \\
(0.30)\end{array}$ & $\begin{array}{l}-2.09 \\
(1.16)\end{array}$ & $\begin{array}{c}0.44 \\
(0.77)\end{array}$ & $\begin{array}{c}1.14 \\
(1.18)\end{array}$ & $\begin{array}{l}-4.58 \\
(1.07)\end{array}$ & $\begin{array}{c}1.47 \\
(0.54)\end{array}$ & $\begin{array}{c}1.49 \\
(0.85)\end{array}$ & $\begin{array}{l}-0.03 \\
(0.59)\end{array}$ & $\begin{array}{c}0.84 \\
(0.83)\end{array}$ & $\begin{array}{c}1.33 \\
(1.47)\end{array}$ \\
\hline 5. Health & $\begin{array}{l}-1.08 \\
(0.50)\end{array}$ & $\begin{array}{c}0.15 \\
(1.96)\end{array}$ & $\begin{array}{c}0.79 \\
(1.29)\end{array}$ & $\begin{array}{c}1.95 \\
(1.99)\end{array}$ & $\begin{array}{c}1.48 \\
(1.80)\end{array}$ & $\begin{array}{l}-6.14 \\
(0.91)\end{array}$ & $\begin{array}{c}0.02 \\
(1.44)\end{array}$ & $\begin{array}{l}-0.05 \\
(0.99)\end{array}$ & $\begin{array}{c}1.98 \\
(1.40)\end{array}$ & $\begin{array}{l}-0.18 \\
(2.49)\end{array}$ \\
\hline 6. Education & $\begin{array}{c}0.09 \\
(0.59)\end{array}$ & $\begin{array}{l}-0.63 \\
(2.32)\end{array}$ & $\begin{array}{l}-0.56 \\
(1.53)\end{array}$ & $\begin{array}{c}3.33 \\
(2.36)\end{array}$ & $\begin{array}{c}0.66 \\
(2.13)\end{array}$ & $\begin{array}{c}0.61 \\
(1.08)\end{array}$ & $\begin{array}{l}-5.98 \\
(1.70)\end{array}$ & $\begin{array}{c}0.75 \\
(1.17)\end{array}$ & $\begin{array}{c}3.46 \\
(1.66)\end{array}$ & $\begin{array}{l}-1.63 \\
(2.94)\end{array}$ \\
\hline 7. Restaurants & $\begin{array}{l}-0.56 \\
(0.69)\end{array}$ & $\begin{array}{l}-1.63 \\
(2.73)\end{array}$ & $\begin{array}{c}1.6 \\
(1.80)\end{array}$ & $\begin{array}{c}1.77 \\
(2.77)\end{array}$ & $\begin{array}{l}-1.84 \\
(2.51)\end{array}$ & $\begin{array}{c}1.18 \\
(1.27)\end{array}$ & $\begin{array}{l}-0.89 \\
(2.00)\end{array}$ & $\begin{array}{l}-1.83 \\
(1.38)\end{array}$ & $\begin{array}{c}-0.6 \\
(1.95)\end{array}$ & $\begin{array}{c}2.23 \\
(3.46)\end{array}$ \\
\hline 8. Recreation & $\begin{array}{c}0.14 \\
(0.37)\end{array}$ & $\begin{array}{c}0.87 \\
(1.44)\end{array}$ & $\begin{array}{c}1.14 \\
(0.95)\end{array}$ & $\begin{array}{l}-3.41 \\
(1.46)\end{array}$ & $\begin{array}{c}1.45 \\
(1.32)\end{array}$ & $\begin{array}{l}-0.29 \\
(0.67)\end{array}$ & $\begin{array}{c}0.76 \\
(1.06)\end{array}$ & $\begin{array}{c}0.37 \\
(0.73)\end{array}$ & $\begin{array}{l}-4.17 \\
(1.03)\end{array}$ & $\begin{array}{c}3.3 \\
(1.82)\end{array}$ \\
\hline 9. Miscellaneous & $\begin{array}{c}2.59 \\
(1.01)\end{array}$ & $\begin{array}{l}12.79 \\
(3.96)\end{array}$ & $\begin{array}{c}-1.01 \\
(2.61)\end{array}$ & $\begin{array}{l}-7.36 \\
(4.02)\end{array}$ & $\begin{array}{c}2.29 \\
(3.64)\end{array}$ & $\begin{array}{c}0.4 \\
(1.84)\end{array}$ & $\begin{array}{c}2.02 \\
(2.91)\end{array}$ & $\begin{array}{l}-1.73 \\
(2.00)\end{array}$ & $\begin{array}{l}-0.08 \\
(2.83)\end{array}$ & $\begin{array}{l}-7.32 \\
(5.02)\end{array}$ \\
\hline \multicolumn{11}{|c|}{ B. Symmetry-constrained } \\
\hline 1. Food & $\begin{array}{l}-2.27 \\
(1.37)\end{array}$ & $\begin{array}{c}-12.73 \\
(5.54)\end{array}$ & $\begin{array}{c}4.67 \\
(1.45)\end{array}$ & $\begin{array}{c}1.15 \\
(3.19)\end{array}$ & $\begin{array}{l}-1.97 \\
(1.13)\end{array}$ & $\begin{array}{c}1.13 \\
(1.48)\end{array}$ & $\begin{array}{c}0.46 \\
(2.06)\end{array}$ & $\begin{array}{l}-2.11 \\
(1.90)\end{array}$ & $\begin{array}{c}0.43 \\
(1.32)\end{array}$ & $\begin{array}{c}8.98 \\
(3.55)\end{array}$ \\
\hline 2. Clothing & $\begin{array}{c}0.37 \\
(0.40)\end{array}$ & & $\begin{array}{c}-4.1 \\
(1.00)\end{array}$ & $\begin{array}{c}0.52 \\
(1.30)\end{array}$ & $\begin{array}{l}-0.25 \\
(0.67)\end{array}$ & $\begin{array}{l}-2.06 \\
(0.60)\end{array}$ & $\begin{array}{c}0.68 \\
(0.90)\end{array}$ & $\begin{array}{l}-0.62 \\
(0.69)\end{array}$ & $\begin{array}{c}0.77 \\
(0.68)\end{array}$ & $\begin{array}{c}0.39 \\
(1.54)\end{array}$ \\
\hline 3. Housing & $\begin{array}{c}0.93 \\
(1.07)\end{array}$ & & & $\begin{array}{l}-5.19 \\
(3.45)\end{array}$ & $\begin{array}{c}1.53 \\
(1.09)\end{array}$ & $\begin{array}{c}2.81 \\
(1.21)\end{array}$ & $\begin{array}{c}0.4 \\
(1.72)\end{array}$ & $\begin{array}{c}3.61 \\
(1.47)\end{array}$ & $\begin{array}{l}-2.23 \\
(1.16)\end{array}$ & $\begin{array}{c}-2.6 \\
(2.88)\end{array}$ \\
\hline 4. Furnishings & $\begin{array}{l}-0.06 \\
(0.29)\end{array}$ & & & & $\begin{array}{l}-3.93 \\
(1.04)\end{array}$ & $\begin{array}{c}1.57 \\
(0.50)\end{array}$ & $\begin{array}{c}1.39 \\
(0.78)\end{array}$ & $\begin{array}{l}-0.31 \\
(0.56)\end{array}$ & $\begin{array}{c}0.98 \\
(0.68)\end{array}$ & $\begin{array}{c}0.99 \\
(1.35)\end{array}$ \\
\hline 5. Health & $\begin{array}{l}-0.74 \\
(0.48)\end{array}$ & & & & & $\begin{array}{l}-6.04 \\
(0.81)\end{array}$ & $\begin{array}{c}0.97 \\
(0.82)\end{array}$ & $\begin{array}{c}0.22 \\
(0.73)\end{array}$ & $\begin{array}{c}0.23 \\
(0.57)\end{array}$ & $\begin{array}{c}1.17 \\
(1.43)\end{array}$ \\
\hline 6. Education & $\begin{array}{c}0.22 \\
(0.57)\end{array}$ & & & & & & $\begin{array}{c}-5.84 \\
(1.68)\end{array}$ & $\begin{array}{c}0.41 \\
(0.98)\end{array}$ & $\begin{array}{c}1.35 \\
(0.84)\end{array}$ & $\begin{array}{c}0.17 \\
(2.00)\end{array}$ \\
\hline 7. Restaurants & $\begin{array}{c}-0.43 \\
(0.64)\end{array}$ & & & & & & & $\begin{array}{l}-1.75 \\
(1.25)\end{array}$ & $\begin{array}{c}0.72 \\
(0.63)\end{array}$ & $\begin{array}{l}-0.17 \\
(1.65)\end{array}$ \\
\hline 8. Recreation & $\begin{array}{c}0.12 \\
(0.36)\end{array}$ & & & & & & & & $\begin{array}{l}-4.47 \\
(0.93)\end{array}$ & $\begin{array}{c}2.22 \\
(1.43)\end{array}$ \\
\hline 9. Miscellaneous & $\begin{array}{c}1.85 \\
(0.98)\end{array}$ & & & & & & & & & $\begin{array}{r}-11.14 \\
(4.70)\end{array}$ \\
\hline \multicolumn{11}{|c|}{ price effects } \\
\hline 1. Food & $\begin{array}{l}-0.58 \\
(1.19)\end{array}$ & & & & & & & & & \\
\hline 2. Clothing & $\begin{array}{l}-0.26 \\
(0.36)\end{array}$ & & & & & & & & & \\
\hline 3. Housing & $\begin{array}{c}0.18 \\
(0.95)\end{array}$ & & & & & & & & & \\
\hline 4. Furnishings & $\begin{array}{c}0.01 \\
(0.28)\end{array}$ & & & & & & & & & \\
\hline 5. Health & $\begin{array}{c}0.18 \\
(0.57)\end{array}$ & & & & & & & & & \\
\hline 6. Education & $\begin{array}{c}0.02 \\
(0.53)\end{array}$ & & & & & & & & & \\
\hline 7. Restaurants & $\begin{array}{l}-0.23 \\
(0.56)\end{array}$ & & & & & & & & & \\
\hline 8. Recreation & $\begin{array}{c}0.24 \\
(0.38)\end{array}$ & & & & & & & & & \\
\hline 9. Miscellaneous & $\begin{array}{c}0.43 \\
(0.87)\end{array}$ & & & & & & & & & \\
\hline
\end{tabular}

Note: This table presents three sets of estimates of model (A7.1) for countries with incomes lower than the median. See note to Table A7.7. 
A-34

Figure A6.1. Global Food Demand Projections, 2017 - 2026

\section{A. Total Demand}

A1. Baseline estimates (ICP data) Sbil.

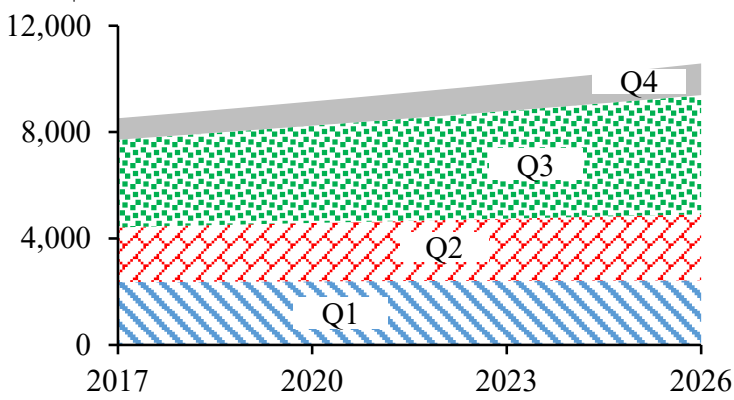

\section{A2. Post-COVID-19 estimates (IMF data)}

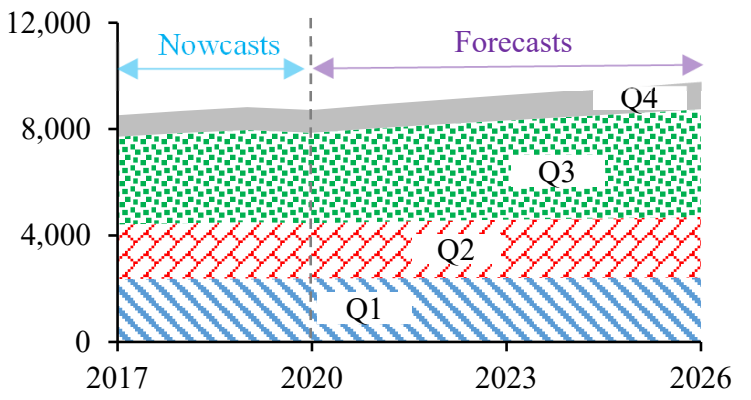

B. Per Capita Demand

$(2017=100)$

B1. First quartile

Food demand index

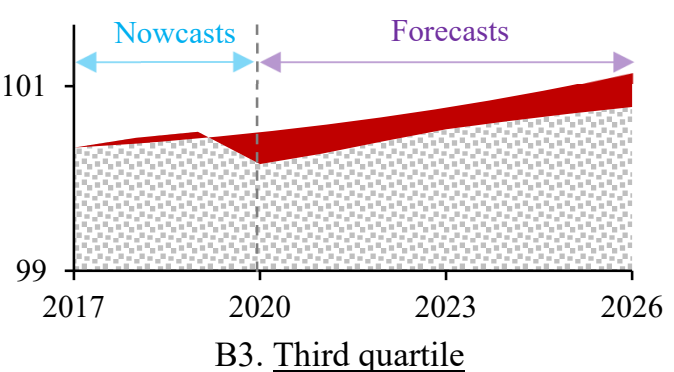

B3. Third quartile

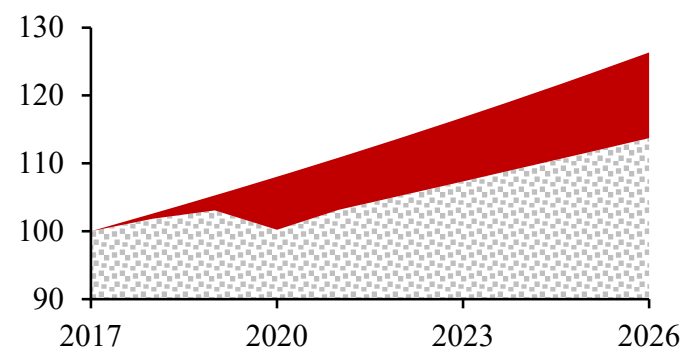

B2. Second quartile
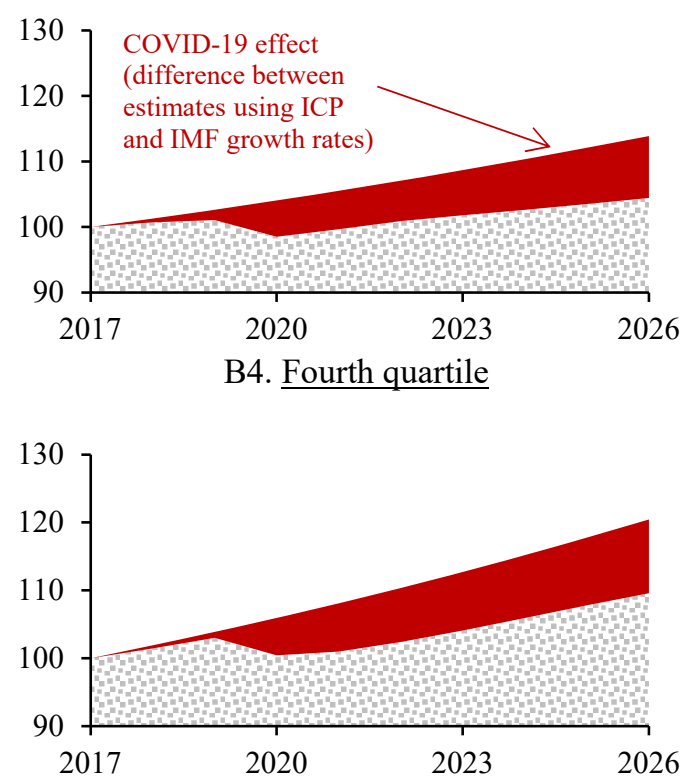

B5. All countries

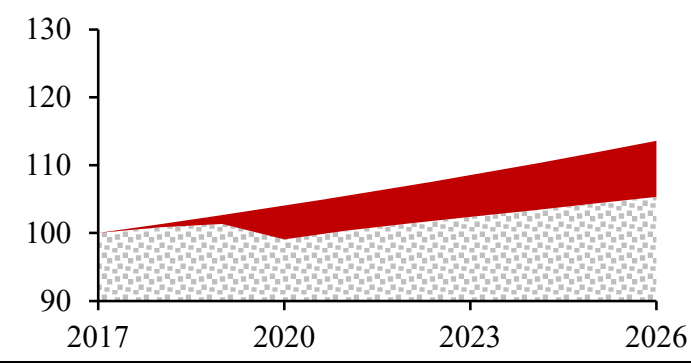

Notes:

1. Panel A: This panel presents projections of food demand aggregated across all countries in each income quartiles. See notes to Table 14 for details. Values are in billion US dollars at 2017 PPP rates.

2. Panel B: This panel gives per capita food demand by quartile, with $2017=100$, and highlights the difference between the two sets of projections (the red shaded areas). As the IMF income growth projections are generally lower than those of the ICP, the differences between the projections can be interpreted as approximating the effects of the COVID-19 pandemic on food demand. 
A-35

Figure A7.1. Comparing Estimates, Pooled Regression vs. Alternatives

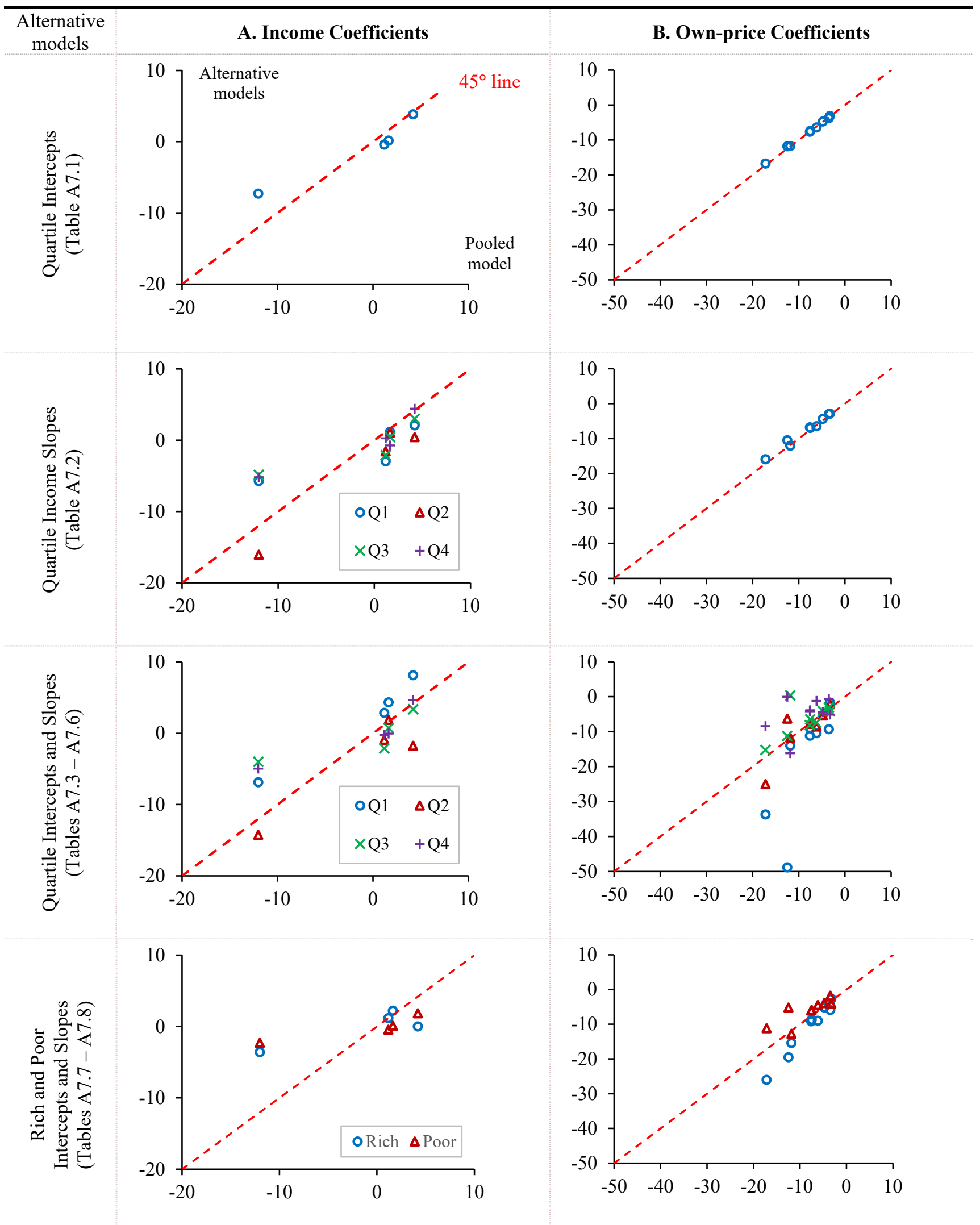

Note: This figure shows the coefficients of the baseline/pooled model, presented in panel B of Table 4 (horizontal axis), against those from alternative quartile-specific models (vertical axis) presented in panel B of Tables A7.1 to A7.8. Panel $\mathrm{B}$ of this figure deals with all nine commodities, while panel A considers only Food, Restaurants, Recreation and Miscellaneous, the commodities with statistically significant income coefficient estimates from panel B of Table 4. All estimates are multiplied by 100 . 